\title{
Technology, Safety and Costs of Decommissioning a Reference Boiling Water Reactor Power Station
}

Main Report

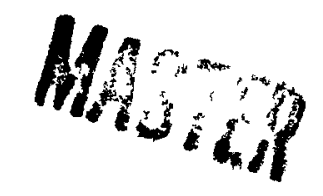

Prepared by H. D. Oak, G. M. Holter, W. E. Kennedy, Jr., G. J. Konzek

Pacific Northwest Laboratory

Operated by

Battelle Memorial Institute

Prepared for

U. S. Nuclear Regulatory

Commission 


\section{NOTICE}

This report was prepared as an account of work sponsored by an agency of the United States Government Neither the United States Government nor any agency thereof, or any of their employees, makes any warranty, expressed or implied, or assumes any legal liability or responsibility for any third party's use, or the results of such use, of any information, apparatus product or process disclosed in this report, or represents that its use by such third party would not infringe privately owned rights.

\section{Available from}

GPO Sales Program

Division of Technical Information and Document Control

U. S. Nuclear Regulatory Commission

Washington, D. C. 20555

Printed copy price:

and

National Technical Information Service

Springfield, Virginia 22161 


\section{DISCLAIMER}

This report was prepared as an account of work sponsored by an agency of the United States Government. Neither the United States Government nor any agency Thereof, nor any of their employees, makes any warranty, express or implied, or assumes any legal liability or responsibility for the accuracy, completeness, or usefulness of any information, apparatus, product, or process disclosed, or represents that its use would not infringe privately owned rights. Reference herein to any specific commercial product, process, or service by trade name, trademark, manufacturer, or otherwise does not necessarily constitute or imply its endorsement, recommendation, or favoring by the United States Government or any agency thereof. The views and opinions of authors expressed herein do not necessarily state or reflect those of the United States Government or any agency thereof. 


\section{DISCLAIMER}

Portions of this document may be illegible in electronic image products. Images are produced from the best available original document. 


\title{
Technology, Safety and Costs of Decommissioning a Reference Boiling Water Reactor Power Station
}

\author{
Main Report
}

Manuscript Completed: October 1979

Date Published: June 1980

Prepared by

H. D. Oak, G. M. Holter, W. E. Kennedy, Jr., G. J. Konzek

Pacific Northwest Laboratory

Richland, WA 99352

\section{Prepared for \\ Division of Engineering Standards \\ Office of Standards Development \\ U.S. Nuclear Regulatory Commission \\ Washington, D.C. 20555 \\ NRC FIN No. B2117}

\section{DISCLAIMER}

This report was prepared as an account of work sponsored by an agency of the United States Government. Neither the United States Government nor any agency thereof, nor any of their employees, makes any warranty, express or implied, or assumes any legal liability or responsibility for the accuracy, completeness, or usefulness of any information, apparatus, product, or process disclosed, or represents that its use would not infringe privately owned rights. Reference herein to any specific commercial product, process, or service by trade name, trademark, manufacturer, or otherwise does not necessarily constitute or imply its endorsement, recommendation, or favoring by the United States Government or any agency thereof. The views and opinions of authors expressed herein do not necessarily state or reflect those of the United States Government or any agency thereof. 
•

•. 


\section{STUDY CONTRIBUTORS}

STUDY LEADER

H. D. Oak

CHAPTER 1 - INTRODUCTION

H. D. Oak

CHAPTER 2 - SUMMARY

R. I. Smith

CHAPTER 3 - STUDY APPROACH AND BASES

H. D. Oak

CHAPTER 4 - DECOMMISSIONING: ALTERNATIVES CONSIDERATIONS, AND EXPERIENCE

H. D. Oak

CHAPTER 5 - REGULATORY CONSIDERATIONS FOR DECOMMISSIONING

H. D. Oak

CHAPTER 6 - FINANCING OF DECOMMISSIONING

R. I. Smith,

P. L. Hendrickson,

G. M. Holter

CHAPTER 7 - CHARACTERISTICS OF THE REFERENCE BWR POWER STATION

H. D. Oak

W. E. Kennedy, Jr.

M. H. Arndt(a)

CHAPTER 8 - SUGGESTED METHODOLOGY FOR DETERMINING ACCEPTABLE RESIDUAL RADIOACTIVE CONTAMINATION LEVELS FOR THE DECOMMISSIONED BWR

W. E. Kennedy, Jr.

(a)Private consultant.
CHAPTER 9 - DECOMMISSIONING ACTIVITIES AND MANPOWER REQUIREMENTS

N. G. Wittenbrock

G. J. Konzek

G. M. Holter

CHAPTER 10 - DECOMMISSIONING COSTS

N. G. Wittenbrock

G. J. Konzek

G. M. Holter

CHAPTER 11 - DECOMMISSIONING SAFETY

W. E. Kennedy, Jr.

N. G. Wittenbrock

CHAPTER 12 - COMPARISONS WITH OTHER STUDIES

N. G. Wittenbrock

CHAPTER 13 - CONSIDERATIONS FOR DECOMMISSIONING FACILITATION

E. B. Moore

CHAPTER 14 - IMPACTS OF ALTERNATE STUDY BASES

R. I. Smith

CHAPTER 15 - GLOSSARY

G. M. Holter

EDITOR

D. R. Payson

PROJECT MANAGER

R. I. Smith 
FOREWORD

BY

NUCLEAR REGULATORY COMMISSION STAFF

The NRC staff is in the process of reappraising its regulatory position relative to the decommissioning of nuclear facilities. (1) As a part of this activity NRC has initiated two series of studies through technical assistance contracts. These contracts are being undertaken to develop information to support the preparation of new standards covering decommissioning.

The basic series of studies will cover the technology, safety and costs of decommissioning reference nuclear facilities. Light water reactors, fuel cycle facilities and byproduct utilization facilities are included. Facilities of current design on typical sites are selected for the studies. Separate reports will be prepared as the studies of the various facilities are completed.

The first report in this series was published in FY 1977 and covered a fuel reprocessing plant; ${ }^{(2)}$ the second was published in FY 1978 and covered a pressurized water reactor; ${ }^{(3)}$ the third of the series was published in FY 1979 and dealt with a small mixed oxide fuel fabrication plant. (4) An addendum to the pressurized water reactor report ${ }^{(5)}$ was issued during FY 1979 which examined the relationship between reactor size and decommissioning cost, the cost of entombment, and the sensitivity of cost to radiation levels, contractual arrangements, and disposal site

(1)Plan for Reevaluation of NRC Policy on Decommissioning of Nuclear Facilities. NUREG-0436, Rev. 1, Office of Standards Development, U.S. Nuclear Regulatory Commission, December 1978.

(2) Technology, Safety and Costs of Decommissioning a Reference Nuclear Fuel Reprocessing Plant. NUREG-0278, Pacific Northwest Laboratory for U.S. NucTear Regulatory Commission, October 1977.

(3) Technology, Safety and Costs of Decommissioning a Reference Pressurized Water Reactor Power Station. NUREG/CR-0130, Pacific Northwest Laboratory for U.S. Nuclear Regulatory Commission, June 1978.

(4) Technology, Safety and Costs of Decommissioning a Reference Small Mixed Oxide Fuel Fabrication Plant. NUREG/CR-0129, Pacific Northwest Laboratory for U.S. Nuclear Regulatory Commission, February 1979.

(5)Technology, Safety and Costs of Decommissioning a Reference Pressurized Water Reactor Power Station. NUREG/CR-0130 Addendum, Pacific Northwest Laboratory for U.S. Nuclear Regulatory Commission, August 1979. 
charges. The most recent report in this series dealt with a low-level waste burial ground. (6) The following report, sixth of the series, provides information on the technology, safety and costs of decommissioning a large boiling water reactor power station. Additional topics will be reported on the tentative schedule as follows:

FY 1980 - Uranium Fabrication Plant

FY 1981 - Non-Fuel Cycle Nuclear Facilities

FY 1981 - Multiple Reactor Facilities

The second series of studies covers supporting information on the decommissioning of nuclear facilities. Three reports have been issued in the second series. The first consists of an annotated bibliography on the decommissioning of nuclear facilities. (7) The second is a review and analysis of current decommissioning regulations. (8) The third of this series covers the facilitation of the decommissioning of light water reactors. (9) The major purpose is to identify modifications or design changes to facilities, equipment and procedures which will improve safety and/or reduce costs.

The information provided in this report on the boiling water reactor, including any comments, will be included in the record for consideration by the Commission in establishing criteria and new standards for decommissioning. Persons wishing to comment on this report should mail their comments to:

Chief

Fuel Process Systems Standards Branch

Division of Engineering Standards

Office of Standards Development

U.S. Nuclear Regulatory Commission

Washington, DC 20555

(6) Technology, Safety and Costs of Decommissioning a Reference Low-Level Waste Burial Ground. NUREG/CR-0570, Pacific Northwest Laboratory for U.S. Nuclear Regulatory Commission, May 1980.

(7)Decommissioning of Nuclear Facilities - An Annotated Bibliography. NUREG/CR-0130, Pacific Northwest Laboratory for U.S. Nuclear Regulatory Commission, September 1978.

(8) Decommissioning of Nuclear Facilities - A Review and Analysis of Current Regulations. NUREG/CR-0671, Pacific Northwest Laboratory for U.S. Nuclear Regulatory Commission, August 1979.

(9) Facilitation of Decommissioning of Light Water Reactors. NUREG/CR-0569, Pacific Northwest Laboratory for U.S. Nuclear Regulatory Commission, December 1979. 


\section{ABSTRACT}

Safety and cost information is developed for the conceptual decommissioning of a large [1155-MW(e)] boiling water reactor (BWR) power station. Three approaches to decommissioning--immediate dismantlement, entombment, and passive safe storage with deferred dismantlement--are studied to obtain comparisons between costs, occupational radiation doses, potential radiation dose to the public, and other safety impacts.

Dismantling the reference BWR immediately following shutdown is estimated to cost $\$ 43.6$ million (in 1978 dollars), to require about 2 years for planning and preparation prior to final reactor shutdown, to require about $3-1 / 2$ years for active decommissioning following final reactor shutdown, and to result in radiation doses to decommissioning workers of about 1845 man-rem.

Preparing the reference BWR for passive safe storage, safe storage for 30 years, and deferred dismantlement after 30 years are estimated to cost $\$ 58.8$ million (in 1978 dollars). It is estimated that about $1-1 / 2$ years will be required for planning and preparation prior to shutdown and that about 3 years will be required to place the facility in passive safe storage, resulting in an estimated radiation dose to decommissioning workers of about 418 man-rem.

Entombing the reference BWR is estimated to cost $\$ 40.6$ million (in 1978 dollars), to require about 2 years for planning and preparation prior to final reactor shutdown, to require about 4 years for active decommissioning following final reactor shutdown, and to result in radiation doses to decommissioning workers of about 1684 man-rem.

Costs of continuing care during passive safe storage and entombment are estimated to be $\$ 75,000$ and $\$ 40,000$ per year, respectively.

Dismantling the reference BWR after periods of safe storage is estimated to cost somewhere between $\$ 36$ million and $\$ 20$ million, depending on the storage mode employed and the duration of the storage period, to require a time span equivalent to immediate dismantlement, and to result in radiation doses to decommissioning workers that range from about 495 man-rem for dismantlement after 10 years of storage to a few man-rem after 50 years of storage. 
The safety impacts of the decommissioning operations on the public are found to be small, with the principal impact on the public being the radiation dose resulting from the transport of radioactive materials to a disposal site. 


\section{REPORT CONTENTS OUTLINE}

VOLUME ?

CHAPTER 1 - INTRODUCTION

CHAPTER 2 - SUMMARY

CHAPTER 3 - STUDY APPROACH AND BASES

CHAPTER 4 - DECOMMISSIONING: ALTERNATIVES, CONSIDERATIONS, AND EXPERIENCE

CHAPTER 5 - REGULATORY CONSIDERATIONS FOR DECOMMISSIONING

CHAPTER 6 - FINANCING OF DECOMMISSIONING

CHAPTER 7 - CHARACTERISTICS OF THE REFERENCE BWR POWER STATION

CHAPTER 8 - SUGGESTED METHODOLOGY FOR DETERMINING ACCEPTABLE RESIDUAL RADIOACTIVE CONTAMINATION LEVELS FOR THE DECOMMISSIONED BWR

CHAPTER 9 - DECOMMISSIONING ACTIVITIES AND MANPOWER REQUIREMENTS

CHAPTER 10 - DECOMMISSIONING COSTS

CHAPTER 11 - DECOMMISSIONING SAFETY

CHAPTER 12 - COMPARISONS WITH OTHER STUDIES

CHAPTER 13 - CONSIDERATIONS FOR DECOMMISSIONING FACILITATION

CHAPTER 14 - IMPACTS OF ALTERNATE STUDY BASES

CHAPTER 15 - GLOSSARY

VOLUME 2

APPENDIX A - EVALUATIONS OF DECOMMISSIONING FINANCING ALTERNATIVES

APPENDIX B - REFERENCE SITE DESCRIPTION

APPENDIX C - REFERENCE BWR FACILITY DESCRIPTION

APPENDIX D - RADIATION DOSE RATE AND CONCRETE SURFACE CONTAMINATION DATA

APPENDIX E - RADIONUCLIDE INVENTORIES

APPENDIX $F$ - PUBLIC RADIATION DOSE MODELS AND CALCULATED MAXIMUM ANNUAL DOSES

APPENDIX G - DECOMMISSIONING METHODS

APPENDIX H - GENERIC DECOMMISSIONING INFORMATION

APPENDIX I - IMMEDIATE DISMANTLEMENT DETAILS

APPENDIX J - PASSIVE SAFE STORAGE, CONTINUING CARE, AND DEFERRED DISMANTLEMENT DETAILS

APPENDIX $K$ - ENTOMBMENT DETAILS

APPENDIX L - DEMOLITION AND SITE RESTORATION DETAILS

APPENDIX M - COST ESTIMATING BASES

APPENDIX $N$ - PUBLIC RADIOLOGICAL SAFETY ASSESSMENT DETAILS

APPENDIX 0 - DETAILS OF ALTERNATE STUDY BASES

$$
\mathrm{ix} / \mathrm{X}
$$


0

0 


\section{CONTENTS}

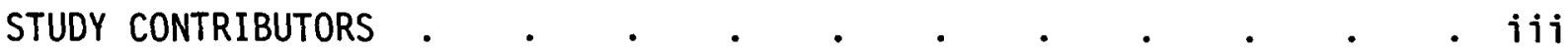

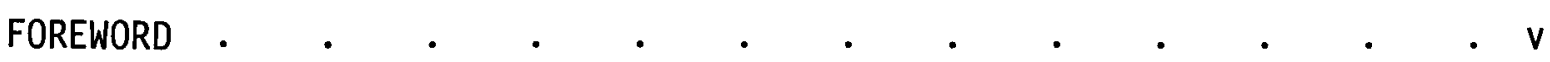

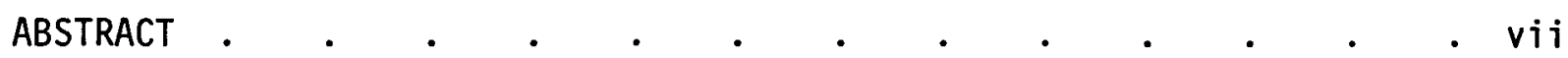

REPORT CONTENTS OUTLINE

FIGURES

TABLES

CHAPTER 1 - INTRODUCTION .

CHAPTER 2 - SUMMARY . . . . . . . . . . . . . . . 2-1

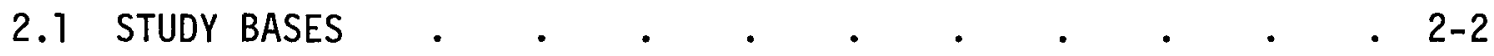

2.2 DECOMMISSIONING ALTERNATIVES . . . . . . . . . 2-3

2.3 DECOMMISSIONING EXPERIENCE $\quad$. . . . . . . . . . . 2-4

2.4 REGULATORY GUIDANCE FOR DECOMMISSIONING . • • . . . 2-4

2.5 FINANCING DECOMMISSIONING $\quad . \quad$. $\quad . \quad$. . . . . $2-5$

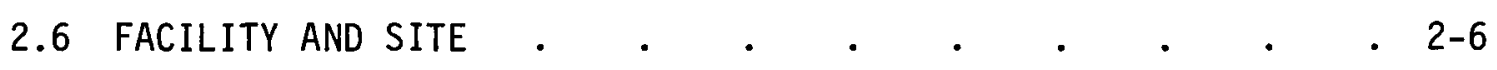

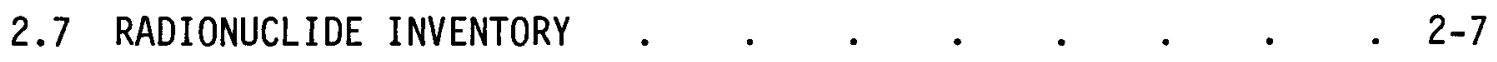

2.8 EXAMPLE ACCEPTABLE CONTAMINATION LEVELS FOR UNRESTRICTED USE

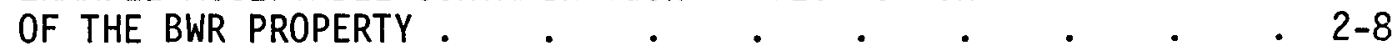

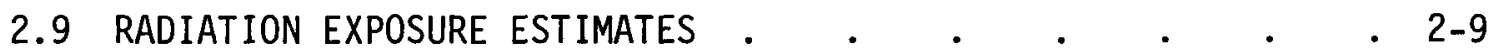

2.10 DECOMMISSIONING COSTS . . . . . . . . . 2-11

2.11 OCCUPATIONAL AND PUBLIC SAFETY . $\quad . \quad \cdot \quad \cdot \quad \cdot \quad$ 2-15

2.12 COMPARISON WITH OTHER STUDIES . $\quad . \quad$. $\quad . \quad$. . . 2-16

2.13 FACILITATION OF DECOMMISSIONING . . . . . . . 2-16

2.14 IMPACTS OF ALTERNATE STUDY BASES . . . . . . . 2-16

2.15 CONCLUSIONS AND RECOMMENDATIONS . . . . . . . . 2-17 
CHAPTER 3 - STUDY APPROACH' AND BASES . . . . . . . . . . 3-1

3.1 STUDY APPROACH . . . . . . . . . . . . .

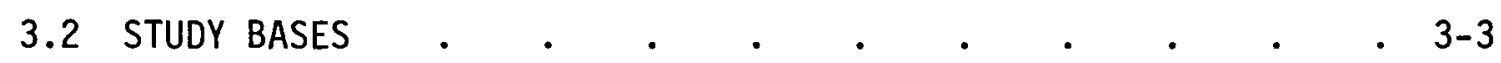

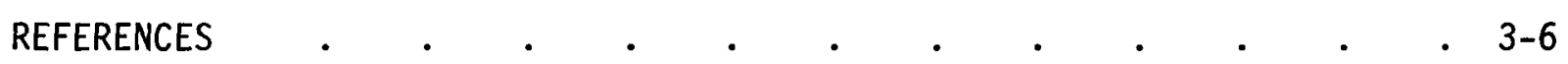

CHAPTER 4 - DECOMMISSIONING: ALTERNATIVES, CONSIDERATIONS AND EXPERIENCE . . . . . . . . . . 4 4-1

4.1 ALTERNATIVES FOR DECOMMISSIONING . . . . . . . . 4-1

4.1.1 Dismantlement $\quad . \quad$. $\quad . \quad . \quad . \quad . \quad . \quad 4-1$

4.1.2 Safe Storage . . . . . . . . . . 4-3

4.1 .3 Entombment . . . . . . . . . . . 4-6

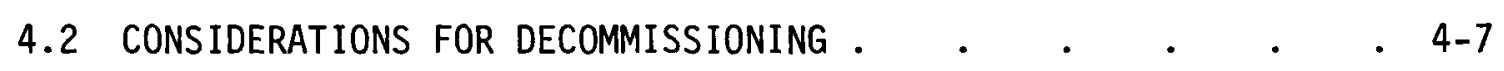

4.2.1 Economic $. \quad . \quad . \quad . \quad . \quad . \quad . \quad . \quad . \quad . \quad 4-7$

4.2.1.1 Property Utilization Potential . . . . 4-7

4.2.1.2 Staffing . . . . . . . . . . $4-8$

4.2.1.3 Radioactive Material Disposition . . . 4-9

4.2.1.4 Waste Disposal Capabilities . . . . 4-9

4.2.1.5 Planning and Preparation Requirements . . 4-10

4.2.1.6 Taxation . . . . . . . . . . . 4-10

4.2.1.7 License and Insurance Fees . . . . 4-11

4.2.1.8 Funding Availability . . . . . . . 4-12

4.2.2 Licensing . . . . . . . . . . . . 4-12

4.2 .3 Societal $\quad . \quad . \quad . \quad . \quad . \quad . \quad . \quad . \quad . \quad 4-13$

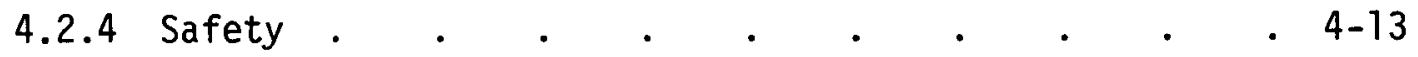

4.2.4.1 Radiological Safety . . . . . . 4-13

4.2.4.2 Industrial Safety . . . . . . . 4-14

4.2.4.3 Environmental Safety . : . . . . 4-14

4.2 .5 Schedule $\quad . \quad$. $\quad . \quad$. 
4.3 EXPERIENCE IN DECOMMISSIONING . . . . . . . . . . 4-15

4.3.1 Nuclear Reactor Decommissioning Experience . . . 4-16

4.3.1.1 Carolina-Virginia Tube Reactor (CVTR), Parr,

South Carolina . . . . . . 4-17

4.3.1.2 Hallam Nuclear Power Facility, Hallam, Nebraska 4-17

4.3.1.3 Piqua Nuclear Power Facility, Piqua, Ohio • 4-20

4.3.1.4 Boiling Nuclear Superheater (BONUS) Power
Station, Ricon, Puerto Rico . . 4-21

4.3.1.5 Walter Reed Research Reactor, Washington, DC . 4-22

4.3.1.6 Pathfinder, Sioux Falls, South Dakota . . 4-23

4.3.1.7 Saxton Nuclear Experimental Facility, Saxton,

Pennsylvania . . . . . . . 4-23

4.3.1.8 Experimental Breeder Reactor-1 (EBR-1) Idaho

National Engineering Laboratory, Scottsville,

Idaho . . . . . . . . . 4-24

4.3.1.9 Elk River Reactor, Elk River, Minnesota . . 4-24

4.3.1.10 Peach Bottom 1, York County, Pennsylvania . 4-26

4.3.1.11 Sodium Reactor Experiment (SRE), Santa Susana,
California.

4.3.1.12 Other Nuclear Reactor Decommissioning Experience 4-28

4.3.2 Decommissioning History of Nonreactor Nuclear Facili-

ties. . . . . . . . 4 4 29

4.3.3 Lessons from Past Decommissionings . . . . 4-29

4.3.4 Ongoing Experience . . . . . . . . 4-31

REFERENCES .

CHAPTER 5 - REGULATORY CONSIDERATIONS FOR DECOMMISSIONING • . . 5-1

5.1 PLANING AND PREPARATION . . . . . . . . . . 5-1

5.1 .1 Licensing . . . . . . . . . . $5-2$ 
5.1.1.1 Radioactive Waste Handling Plan . . . 5-4

5.1.1.2 Quality Assurance Plan . . . . . 5-5

5.1.1.3 Security and Safeguards Plans . . . . 5-5

5.1.1.4 Environmental Plans . . . . . . 5-6

5.1.2 Licensing and Insurance Costs . . . . . 5-6

5.1.3 Financial Qualification . . . . . . 5-6

5.2 ACTIVE DECOMMISSIONING . . . . . . . . . . 5-7

5.2 .1 Licensing . . . . . . . . . 5-7

5.2.2 Occupational Radiation Safety . . . . . 5-8

5.2.3 Public Radiation Safety . . . . . . 5-9

5.2.4 Special Nuclear Materials Handling . . . . 5-10

5.2.5 Radioactive Waste Handling . . . . . . 5-10

5.2.6 Industrial Safety. . . . . . . . 5-12

5.2.7 License Termination and Facility Release . . . 5-12

5.3 CONTINUING CARE . . . . . . . . . . . . 5-12

5.3.1 Public and Occupational Safety . . . . . 5-13

5.3 .2 Licensing . . . . . . . . . . 5-13

5.4 CONCLUSIONS . $. \quad . \quad . \quad . \quad . \quad . \quad . \quad . \quad$. $5-14$

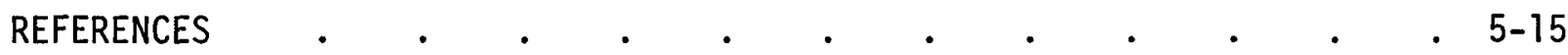

CHAPTER 6 - FINANCING OF DECOMMISSIONING . . . . . . . . 6-1

6.1 NEED FOR ASSURANCE OF DECOMMISSIONING FUNDS . . . . . 6-1

6.2 ALTERNATIVE APPROACHES FOR PROVIDING DECOMMISSIONING FUNDS . 6-2

6.2.1 Prepaid Decommissioning Reserve . . . . . 6-3

6.2.2 Internal Unfunded Decommissioning Reserve . . . 6-4 
6.2.3 Sinking Fund Payment to an Outside Escrow Account . 6-5

6.2.4 Payment from Revenue when Needed . . . . . 6-6

6.3 FINANCIAL PROVISIONS FOR PREMATURE PLANT SHUTDOWN . . 6-6

6.3.1 Large Initial Payment . . . . . . 6-7

6.3.2 Higher Initial Sinking Fund Payments . . . . . 6-7

6.3 .3 Surety Bond . . . . . . . . . . . 6-8

6.3.4 Insurance Pool . . . . . . . . . . 6-8

6.4 PROVISIONS FOR CONTINGENCY COSTS . . . . . . . $\quad$. $6-8$

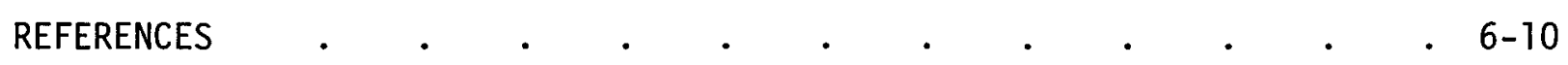

CHAPTER 7 - CHARACTERISTICS OF THE REFERENCE BWR POWER STATION • • $7-1$

7.1 THE REFERENCE SITE . . . . . . . . . . . .

7.2 THE REFERENCE FACILITY . . . . . . . . . . .

7.2.1 Nuclear Power Generation System . . . . . . 7-2

7.2.1.1 Reactor Vessel and Internals . . . . 7-3

7.2.1.2 Reactor Water Recirculation System . . . 7-4

7.2.1.3 Power Conversion System . • . • . . 7-5

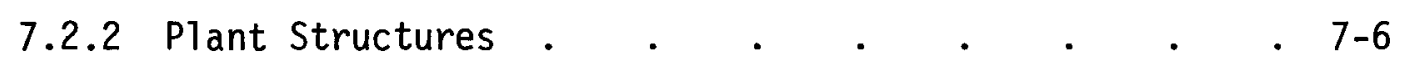

7.2.2.1 Reactor Building . . . . . . . . $7-7$

7.2.2.2 Turbine Generator Building . . . . 7-8

7.2.2.3 Radwaste and Control Building . . . . 7-9

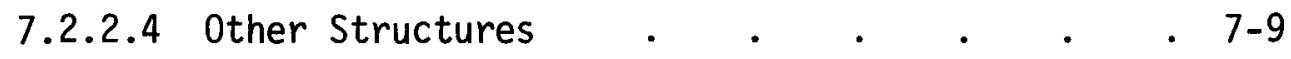

7.3 RADIATION DOSE RATE AND CONCRETE SURFACE CONTAMINATION DATA - 7-11

7.3.1 Estimated Radiation Dose Rates of Shutdown . . . 7-11

\begin{tabular}{l} 
7.3.2 Estimated Concrete Surface Contamination Levels at \\
Shutdown \\
\hline
\end{tabular}

7.3.3 Contaminated Concrete Rubble Volumes Removed During
Immediate Dismantlement $.0 .0 .7-13$ 


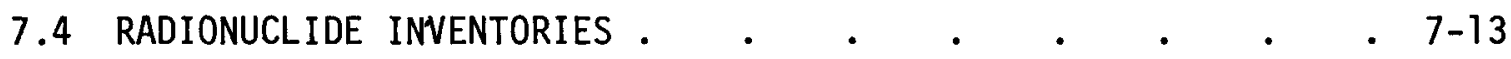

7.4.1 Neutron-Activated Components . . . . . 7-15

7.4.1.1 Radionuclide Inventories in Neutron-Activated

Materials . . . . . . . 7-15

7.4.1.2 Total Radioactivity in Neutron-Activated

Components . . . . . . . . 7-20

7.4.1.3 Dose Rates for Selected Neutron-Activated . . 7-21

7.4.2 Surface Contamination . . . . . . . 7-22

7.4.2.1 Internal Surface Contamination . . . . 7-23

7.4.2.2 External Surface Contamination in the Reference
BWR

7.4.2.3 External Surface Contamination on the Site $\cdot 7-25$

7.4.2.4 Surface Contamination Deposition in the Refer-
ence BWR . . . . . . . . $4-26$

7.5 CHEMICAL INVENTORY . $. \quad . \quad . \quad . \quad . \quad . \quad . \quad$.

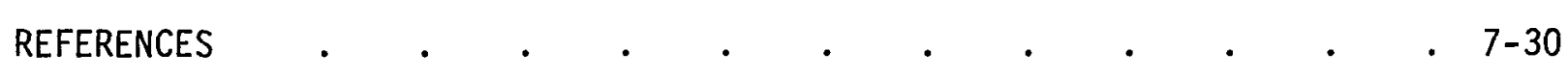

CHAPTER 8 - SUGGESTED METHODOLOGY FOR DETERMINING ACCEPTABLE RESIDUAL
RADIOACTIVE CONTAMINATION LEVELS FOR THE DECOMMISSIONED BWR $8-1$

8.1 TECHNICAL APPROACH .

8.1.1 Terminology and Definitions . . . . . . 8-2

8.1.2 Definition of Use Categories . . . . . 8-3

8.1.3 Acceptable Radioactive Contamination Level Methodology 8-4

8.2 EXAMPLE CALCULATIONS OF ACCEPTABLE RADIOACTIVE CONTAMINATION

LEVELS FOR THE DECOMMISSIONED REFERENCE BWR . . . . 8-7

8.2.1 Acceptable Residual Radioactive Contamination Levels in the Reference BWR Facility . . . . . 8-8

8.2.2 Acceptable Residual Radioactive Contamination Levels
on the Reference BWR Site 8-10

8.2.3 Acceptable Radioactive Contamination Levels on BWR
Equipment . . . . . . . . . . . 
8.3 EXISTING GUIDANCE ON RESIDUAL RADIOACTIVE CONTAMINATION . 8-13

8.4 SUMMARY OF EXAMPLE ACCEPTABLE CONTAMINATION LEVELS . . 8-15

8.5 RADIATION DETECTION CAPABILITIES . . . . . . . . 8-16

REFERENCES •

CHAPTER 9 - DECOMMISSIONING ACTIVITIES AND MANPOWER REQUIREMENTS • . 9-1

9.1 IMMEDIATE DISMANTLEMENT ACTIVITIES AND REQUIREMENTS . . 9-1

9.1.1 Planning and Preparation Activities . . . . 9-1

9.1.1.1 Satisfying Regulatory Requirements . . . 9-2

9.1.1.2 Gathering and Analyzing Data . . . . 9-3

9.1.1.3 Developing Detailed Work Plans and Procedures . 9-3

9.1.1.4 Designing, Procuring, and Testing Special
Equipment. . . 9-4

9.1.1.5 Selecting and Training Staff . . . . 9-4

9.1.1.6 Selecting Specialty Contractors . . . 9-4

9.1.1.7 Removing Accumulated Spent Fuel and Unneeded
Spent Fuel Storage Racks. . 9-5

9.1.1.8 Installing Additional HEPA Filters . . . 9-5

9.1.2 Immediate Dismantlement Activities . . . . 9-5

9.1.2.1 Decontamination . . . . . . . 9-5

9.1.2.2 Disassembly and Disposal . . . . . . 9-7

9.1.2.3 Quality Assurance . . . . . . . 9-9

9.1.2.4 Environmental Surveillance . . . . 9-11

9.1.2.5 Specialty Contractors . . . . . 9-11

9.1.2.6 Essential Systems and Services. . . 9-12

9.1.3 Immediate Dismantlement Schedule . . . . . 9-12

9.1.4 Immediate Dismantlement Staff Requirements . . . 9-17 
9.1.4.1 Organization of the Decommissioning Staff . 9-17

9.1.4.2 Immediate Dismantlement Manpower . . . 9-21

9.2 PASSIVE SAFE STORAGE ACTIVITIES AND MANPOWER REQUIREMENTS • 9-21

9.2.1 Planning and Preparation Activities . . . . 9-26

9.2.2 Passive Safe Storage Preparations Activities . . 9-26

9.2.2.1 Decontamination and Immobilizing

Contamination . . . . . . . . 9-27

9.2.2.2 Systems Deactivation and Isolation of Contaminated Areas . . . . . . 9-28

9.2.2.3 Reduction of Plant Exclusion Area . . . 9-29

9.2.2.4 Quality Assurance . . . . . . 9-29

9.2.2.5 Environmental Surveillance . . . . 9-30

9.2.2.6 Specialty Contractors . . . . 9-30

9.2.2.7 Essential Systems and Services. . . . 9-31

9.2.3 Passive Safe Storage Schedule . . . . . 9-31

9.2.4 Passive Safe Storage Preparations Staff
Requirements . . . . 9-33

9.2.5 Continuing Care Activities and Requirements . . 9-33

9.2.5.1 Quality Assurance . . . . . . 9-35

9.2.5.2 Environmental Surveillance . . . 9-35

9.2.5.3 Security . . . . . . . . . . 9-35

9.2.5.4 Essential Systems and Services Requirements . 9-36

9.2.5.5 Continuing Care Staff Requirements . . . 9-36

9.3 ENTOMBMENT ACTIVITIES AND MANPOWER REQUIREMENTS • • • 9-36

9.3.1 Planning and Preparation Activities . . . 9-37

9.3.2 Entombment Activities . . . . . . . 9-38

9.3.2.1 Decontamination . . . . . . . 9-38 
9.3.2.2 Preparation of the Entombment Structure . . 9-38

9.3.2.3 Disassembly and Disposition of Radioactive Materials. . . . . . . 9-39

9.3.2.4 Quality Assurance . . . . . . 9-40

9.3.2.5 Environmental Surveillance . . . . 9-40

9.3.2.6 Specialty Contractors . . . . . 9-40

9.3.2.7 Essential Systems and Services . . . . 9-41

9.3.3 Entombment Schedule . . . . . . . 9-41

9.3.4 Entombment Staff Requirements . . . . . 9-45

9.4 DEFERRED DISMANTLEMENT ACTIVITIES AND MANPOWER
REQUIREMENTS ...
.

9.4.1 Work Schedule Estimates . . . . . . . 9-48

9.4.2 Deferred Dismantlement Staff Requirements . . . 9-48 CHAPTER 10 - DECOMMISSIONING COSTS . . . . . . . . . . 10-1

10.1 COSTS FOR IMMEDIATE DISMANTLEMENT . . . . . . . . 10- . .

10.1.1 Costs for Disposal of Radioactive Materials . . 10-3

10.1.2 Costs for Staff Labor . . . . . . . 10-5

10.1.3 Costs for Energy . . . . . . . . . 10-5

10.1.4 Costs for Special Tools and Equipment . . . 10-5

10.1.5 Costs for Miscellaneous Supplies . . . . 10-6

10.1.6 Costs for Specialty Contractors . . . . . 10-6

10.1.7 Costs for Nuclear Insurance . . . . . 10-6

10.1.8 Costs for Licensing Fees . . . . . . 10-6

10.1.9 Other Possible Costs . . . . . . . . . 10-7

10.2 COSTS FOR PREPARATIONS FOR PASSIVE SAFE STORAGE . . . 10-8

10.2.1 Costs for Disposal of Radioactive Materials . . 10-8 
10.2.2 Costs for Staff Labor . . . . . . 10-8

10.2.3 Costs for Energy . . . . . . . 10-10

10.2.4 Costs for Special Tools and Equipment . . . 10-10

10.2.5 Costs for Miscellaneous Supplies . . . . 10-10

10.2.6 Costs for Specialty Contractors . . . . 10-11

10.2.7 Costs for Nuclear Insurance . . . . . 10-11

10.2.8 Costs for Licensing Fees . . . . . . 10-11

10.2.9 Other Possible costs . . . . . . . . 10-11

10.2.10 Costs for Continuing Care . . . . . 10-12

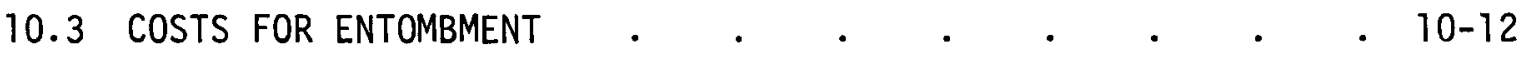

10.3.1 Costs for Disposal of Radioactive Material . . 10-12

-10.3 .2 Costs for Staff Labor . . . . . . . 10-14

10.3.3 Costs for Energy . . . . . . . . . 10-14

10.3.4 Costs for Special Tools and Equipment . . . 10-14

10.3.5 Costs for Miscellaneous Supplies . . . . 10-14

10.3.6 Costs for Specialty Contractors . . . . . 10-15

10.3.7 Costs for Nuclear Insurance and Licensing Fees . . 10-15

10.3.8 Costs for Continuing Care . . . . . . 10-15

10.3.9 Other Possible Costs . . . . . . . 10-15

10.4 COSTS FOR DEFERRED DISMANTLEMENT . . . . . . . . 10-16

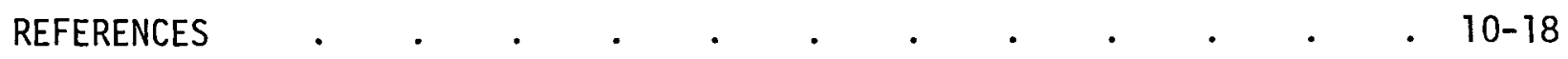

CHAPTER 11 - DECOMMISSIONING SAFETY . . . . . . . . . 11

11.1 TECHNICAL APPROACHES $. \quad . \quad . \quad . \quad . \quad . \quad . \quad$. $111-3$

11.2 OCCUPATIONAL SAFETY OF DECOMMISSIONING THE REFERENCE BWR • 11-5

11.2.1 Occupational Radiation Dose from Decommissioning
Activities. . 11-5 
11.2.2 Industrial Safety . . . . . . . . 11-15

11.3 PUBLIC SAFETY ASPECTS OF DECOMMISSIONING THE REFERENCE BWR . 11-17

11.3.1 Public Radiation Doses from Routine Decommissioning Tasks . . . . . . . . . . 11-17

11.3.2 Public Radiation Doses from Postulated Accidents
During Decommissioning . . . 11-22

11.4 TRANSPORTATION SAFETY

11.4.1 Radiation Doses from Routine Decommissioning

Transportation Tasks . $. \quad . \quad . \quad . \quad . \quad 11-24$

11.4.2 Radiation Doses from Postulated Transportation

Accidents . . . . . . . . . 11-27

11.4.3 Casualties from Traffic Accidents . . . . 11-28 REFERENCES $. \quad . \quad . \quad . \quad . \quad . \quad . \quad . \quad . \quad . \quad . \quad . \quad 11-30$ CHAPTER 12 - COMPARISONS WITH OTHER STUDIES . . . . . . . 12-1

12.1 COMPARISON OF THIS STUDY WITH OTHER BWR STUDIES .

12.1.1 Reference 1: VDEW Study . . . . . . 12-2

12.1.2 Reference 2: ECC-NIS Study . . . . . 12-3

12.1.3 Reference 3: AIF-NES Study . . . . . 12-4

12.1.4 Reference 4: WPPSS Study . . . . . . 12-5

12.1.5 Discussion of BWR Decommissioning Study Results . 12-6

12.2 COMPARISON OF THIS STUDY WITH THE NRC-PNL PWR STUDY . . 12-8

12.2.1 References 5 and 6: NRC-PNL PWR Study . . . 12-8

12.2.2 Comparison of Results . . . . . . . 12-10

REFERENCES . $\quad . \quad . \quad . \quad . \quad . \quad . \quad . \quad . \quad . \quad . \quad .12-13$

CHAPTER 13 - CONSIDERATIONS FOR DECOMMISSIONING FACILITATION

13.1 DECOMMISSIONING FACILITATION ISSUES . . . . . . 13-1

13.1.1 Regulatory Requirements . . . . . . 13-1 
13.1.2 Radiation Dose Reduction Considerations . . . 13-2

13.1.3 Cost Considerations . . . . . . . 13-3

13.1.4 Cost-Benefit Considerations . . . . . 13-3

13.2 DECOMMISSIONING FACILITATION TECHNIQUES . . . . 13-3

13.2.1 Improved Documentation . . . . . . 13-4

13.2.2 Improved Access to Contaminated Equipment . . . 13-5

13.2.3 Different Materials in the Reactor Vessel Internals . 13-5

13.2.4 Protection of Concrete from Contamination . . . 13-6

13.2.5 Improved Shielding . . . . . . . 13-6

13.2.6 Incineration of Combustible Dry Solid Wastes . . 13-7

13.2.7 Electropolishing and Vibratory Finishing . . 13-7

13.2.8 Remote-Controlled Equipment . . . . . 13-7

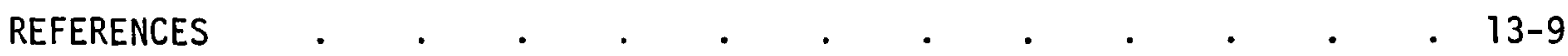

CHAPTER 14 - IMPACTS OF ALTERNATE STUDY BASES . . . . . . . 14-1

14.1 ESTIMATED COSTS AND RADIATION DOSES AS A FUNCTION OF PLANT

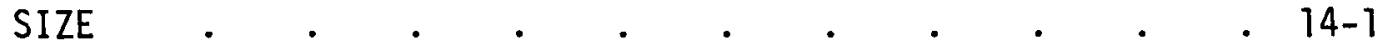

14.2 IMPACT OF INCREASED RADIATION DOSE RATES . . . . . 14-4

14.3 SENSITIVITY OF DECOMMISSIONING COSTS TO CONTRACTUAL

14.4 SENSITIVITY OF DECOMMISSIONING COSTS TO WASTE DISPOSAL $14-5$

14.5 SENSITIVITY OF DECOMMISSIONING COSTS TO PLANT DESIGN • • 14-5

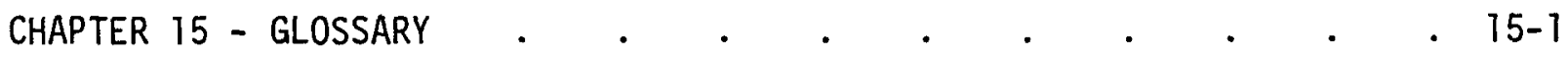

15.1 ABBREVIATIONS, ACRONYMS, AND SYMBOLS . . . . . . 15-1

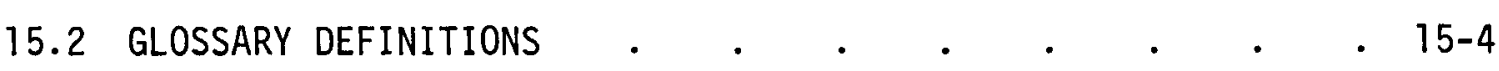

REFERENCES . . . . . . . . . . . . . . . $15-18$ 


\section{FIGURES}

7.2-1 Nuclear Power Generation System . . . . . . . 7-3

7.2-2 Reactor Vessel and Internals . . . . . . . 7-4

7.2-3 Reactor Water Recirculation System . . . . . . 7-5

7.2-4 Power Conversion System . . . . . . . . 7-6

7.2-5 Site Layout of the Reference BWR Power Plant . . . . 7-7

7.2-6 Reactor Building . . . . . . . . . . 7-8

7.4-1 Calculated Buildup of Selected Activation Products in the Core
Shroud as a Function of Time at Full Power.

7.4-2 Time Dependence of Radioactivity and Dose Rate in the NeutronActivated Core Shroud . . . . . . . . . 7-22

7.4-3 Radioactive Decay of Deposited Internal Surface Contamination . 7-28

8.1-1 Relationship of Acceptable Radioactive Contamination Levels to Generic and Site-Specific Studies . . . . . . 8-5

8.1-2 Suggested Methodology for Determining Acceptable Residual Radioactive Contamination Levels . . . . . . . 8-7

9.1-1 Overall Task Schedule and Sequence for Immediate Dismantlement of the Reference BWR . . . . . . . . . 9-15

9.1-2 Decommissioning Staff Organization . . . . . . 9-18

9.2-i Plot Plan of the Exclusion Area for Passive Safe Storage . . 9-30

9.2-2 Task Schedule and Sequence of Preparations for Passive Safe . 9-32

9.2-3 Staff Organization for the Passive Safe Storage Continuing
Care Period. . 9-37

9.3-1 Overall Schedule and Sequence and Decommissioning Worker
Requirements for Scenario-l Entombment Tasks . . . 9-43 
$0^{\prime}$

O 


\section{TABLES}

2.5-1 Revenue Requirements for the Financing Alternatives . . . 2-6

2.8-1 Summary of the Calculated Example Acceptable Residual Radioactive Contamination Levels for the Reference BWR Facility and Site. . . . . . . . . . . 2-9

2.9-1 Summary of Estimated External Occupational Radiation Doses for Decommissioning the Reference BWR . . . . . 2-10

2.9-2 Radiation Dose from Transport of Radioactive Materials from Decommissioning . . . . . . . . . 2-10

2.10-1 Summary of Estimated Costs for Immediate Diṣmantlement . . 2-11

2.10-2 Summary of Estimated Costs for Preparations for Passive Safe Storage . . . . . . . . . . 2-12

2.10-3 Summary of Estimated Costs for Entombment . . . . . 2-13

2.10-4 Total Estimated Costs for Possible Decommissioning Alternatives . . . . . . . . . . 2-14

2.11-1 Summary of Safety Analysis for Decommissioning the Reference

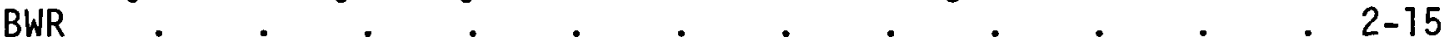

2.15-1 Comparison of Costs and Radiation Doses for Decommissioning the Reference BWR via the Various Alternatives . . . . 2-18

4.1-1 Characteristics of the Various Decommissioning Alternatives . 4-2

4.3-1 Information on Past Nuclear Reactor Decommissionnings . . 4-18

4.3-2 Nonreactor Nuclear Facility Decommissioning Information . . 4-30

7.3-1 Typical Radiation Dose Rates in the Reference BWR at Shutdown . 7-12

7.3-2 Typical Measured Concrete Surface Contamination Levels in the Reference BWR at Shutdown . . . . . . . . 7-14

7.3-3 Contaminated Concrete Rubble Volumes Removed During Immediate
Dismantlement of the Reference BWR . . . . . . .

7.4-1 Reference Radionuclide Inventory 1, Neutron-Activated
Stainless Stee1. . . . . . 7-16

7.4-2 Reference Radionuclide Inventory 2, Neutron-Activated . 7-17 
7.4-3 Reference Radionuclide Inventory 3, Neutron-Activated Concrete

7.4-4 Estimated Total Radioactivity in Neutron-Activated Components

7.4-5 Calculated Radiation Dose Rates from Selected NeutronActivated Reference BWR Components . . . . . . 7-21

7.4-6 Reference Radionuclide Inventory 4, BWR Internal Surface

7.4-7 Reference Radionuclide Inventory 5, BWR Structural Surface External Contamination

7.4-8 Reference Radionuclide Inventory 6, BWR Site Surface Contamination

7.4-9 Summary of Surface Contamination Deposition Data . . . 7-26

7.4-10 Summary of Surface Contamination in the Reference BWR . . 7-27

7.5-1 Expected Annual Chemical Usage During Reference BWR Operation . 7-29

8.2-1 Example Acceptable Residual Radioactive Contamination Levels for Inside the Reference BWR

8.2-2 Example Residual Radioactive Contamination Levels for the Decommissioned BWR Site

8.2-3 Example Acceptable Residual Radioactive Contamination Levels for the Decommissioned BWR Site. . . . . . 8-12

8.3-1 Regulatory Guide 1.86 Acceptable Surface Contamination Levels . 8-13

8.3-2 ANSI N13.12 Surface Contamination Limits . . . . . 8-14

8.4-1 Summary of the Calculated Acceptable Residual Radioactive Contamination Levels for the Reference BWR Facility and Site . 8-15

8.5-1 Comparison of Lower Limits of Detection for NaI Systems with Calculated Example Acceptable Residual Soil Contamination Levels, for Selected Radionuclides . . . . . . . . 8-18

8.5-2 Comparison of Lower Limits of Detection for a Typical Ge(Li) System with-Calculated Example Acceptable Residual Soil Contamination Levels, for a Mixture of Fission Products . . . 8-20

9.1-1 Systems and Services Required During Immediate Dismantlement . 9-13 
9.1-2 Overall Decommissioning Worker Requirements for Immediate Dismantlement of the Reference BWR . . . . . . 9-23

9.1-3 Staff Labor Requirements for Immediate Dismantlement . 9-25

9.2-1 Staff Labor Requirements for Preparations for Passive Safe Storage

9.3-1 Staff Labor Requirements for Scenario-1 Entombment . . . 9-46

10.1-1 Summary of Estimated Costs for Immediate Dismantlement . 10-2

10.2-1 Summary of Estimated Costs for the Preparations for Passive Safe Storage $. \quad . \quad . \quad . \quad . \quad . \quad 10-9$

10.3-1 Summary of Estimated Costs for Entombment . . . . . . 10-13

10.4-1 Estimated Deferred Dismantlement Costs . . . . . 10-16

10.4-2 Total Decommissioning Costs for Passive Safe Storage with Deferred Dismantlement . . . . . . . . 10-17

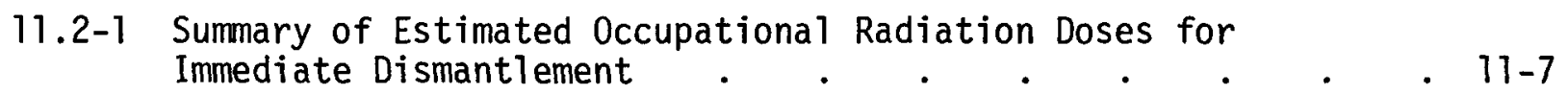

11.2-2 Summary of Estimated Occupational Radiation Doses for
Preparations for Passive Safe Storage . . . . . $11-9$

11.2-3 Summary of Estimated Occupational Radiation Doses for Scenario-1 Entombment . . . . . . . . . 11-11

11.2-4 Estimated Quarterly Occupational Radiation Doses from the
Various Decommissioning Alternatives. . . . . . $11-13$

11.2-5 Summary of the Estimated Occupational Radiation Dose for
Continuing Care . . . . . . . . . . 11-14

11.2-6 Estimated Occupational Radiation Dose from Various
Dismantlement Alternatives . . . . . . . . $11-15$

11.2-7 Estimated Occupational Lost-Time Injuries and Fatalities
from Decommissioning Operations . . . . . . . . 11-16

11.2-8 Estimated Lost-Time Injuries and Fatalities to Decommissioning
Workers from Continuing Care During Passive Safe Storage . 11-18

11.3-1 Summary of Calculated Radiation Doses to the Maximum-Exposed Individual from Atmospheric Releases of Radionuclides During Routine Decommissioning Tasks . . . . . . . 11-20 
11.3-2 Summary of Calculated Radiation Doses to the Population from Atmospheric Releases of Radionuclides During Routine

Decommissioning Tasks.

11.3-3 Summary of Maximum-Exposed Individual Radiation Doses from Postulated BWR Decommissioning Accidents . . . . . 11-23

11.4-1 Calculated Radiation Dose from Rai1 Transport of Spent Fuel . 11-25

11.4-2 Calculated Radiation Dose from Routine Radioactive Waste Transportation . $. \quad . \quad . \quad . \quad . \quad . \quad . \quad . \quad$. $11-26$

11.4-3 Estimated Casualties from Decommissioning Transportation Accidents

12.1-1 Estimated Inventories of Neutron-Activation Products in a Shutdown BWR . . . . . . . . . . 12-7

12.1-2 Estimated Costs for Immediate Dismantlement of a Large BWR . 12-7

12.2-1 Decommissioning Costs for the Reference PWR . . . . 12-10

12.2-2 Summary of Information for Immediate Dismantlement of the Reference PWR and the Reference BWR . . . . . . 12-11

13.2-1 Summary of Possible Decommissioning Facilitation Techniques . 13-4

14.1-1 Scaling Relationships for Decommissioning . . . . . . 14-2

14.1-2 Estimated Costs/0ccupational Radiation Doses for Decommissioning Different Size BWR Plants . . . . . 14-3 


\section{CHAPTER 1}

\section{INTRODUCTION}

This report contains the results of a study sponsored by the Nuclear Regulatory Commission (NRC) to conceptually decommission a present-generation boiling water reactor (BWR) power station. The primary purpose of the study is to provide information on the available technology, the safety considerations, and the probable costs for the decommissioning of a large BWR power station at the end of its operating life. This information is intended for use as background data and bases in the modification of existing regulations and in the development of new regulations pertaining to decommissioning activities. It is also intended for use by utilities in planning for the decommissioning of their nuclear power stations.

Decommissioning of a nuclear facility is defined as the measures taken following the facility's operating life to ensure the protection of the public from any residual radioactivity or other hazards present in the facility. Three approaches to decommissioning are considered in this study:

- Dismantlement - The station is decontaminated, the radioactive materials are removed, and the nuclear license is terminated.

- Safe Storage - The radioactive materials and contaminated areas are decontaminated or secured inside the facility, and surveillance and maintenance continue under the conditions of the nuclear license. Eventual dismantlement is necessary if unrestricted release and license termination is desired.

- Entombment - The radioactive materials and contaminated areas are decontaminated, the nonreleasable materials are confined within a monolithic structure, and surveillance and maintenance continue under the conditions of the nuclear 
license until either the confined radioactivity has decayed to unrestricted release levels or the entombment structure is dismantled.

The NRC's desire to minimize the number of sites permanently committed to the containment of radioactive material is satisfied by immediate dismantlement or safe storage plus deferred dismantlement. Entombment after removal of the long-lived radionuclides for relatively long but not unreasonable periods will result in decay of the entombed radioactive material to levels low enough for unrestricted use; however, certification that release limits for unrestricted use have been met is very difficult short of dismantlement of the entombed facility.

A broad span of safe storage methods is possible. These methods range from a minimal removal and fixation of residual radioactivity and continual onsite maintenance and surveillance, to an extensive cleanup and decontamination with hardened passive protection of highly radioactive materials and periodic surveillance and maintenance. Each method of safe storage requires some level of continuing care during the holding period.

The Washington Public Power Supply System's Nuclear Project Number 2 (WNP-2), at Hanford, Washington, is used as the reference BWR power station for this study. WNP-2 is a 1155-MWe station that utilizes a nuclear steam supply system with a direct-cycle boiling water reactor manufactured by the General Electric Company. The single-reactor station is assumed to be on a generic site that is typical of reactor locations in the midwestern or middle southeastern United States. The structures, systems, and components are basically typical of the current generation of large BWR power stations.

Sets of work plans are developed for the conceptual decommissioning of the reference BWR power station via dismantlement, one method of safe storage, and entombment. From these work plans estimates are developed for the manpower requirements, the major resource and equipment needs, the volumes of contaminated material packaged for disposal, the costs of accomplishing the work, and the exposure of the decommissioning workers and the public to radiation as a result of the decommissioning efforts. Because 
widely different work plans and decommissioning techniques can be utilized to achieve the desired decommissioned condition, the results of the study are dependent upon the detailed choices made. The choices of plans and techniques in this study are believed to be realistic and representative of the operations that would be required to safely decommission the reference BWR power station at a reasonable cost.

A suggested dose-based methodology for determining the level of radioactive contamination that could remain on a site or in a facility and still allow unrestricted use of the property is demonstrated. This methodology utilizes the calculated maximum annual dose to the maximum-exposed individual as the basis for determining these levels. The relationship between dose and contamination level is complex, involving the spectrum of residual radionuclides and their exposure pathways to the maximum-exposed individual.

The work plans and the scenarios for airborne release of radioactive materials are used to evaluate the impacts of decommissioning operations on the workers and the public. Estimates are made of radiation exposure, lost-time injuries, and fatalities for each decommissioning approach studied.

The operating techniques, safety impacts, and estimated costs developed in this study are sensitive to specifics of the reference BWR power station. Such specifics include the mixtures and the levels of residual radioactive contamination at final plant shutdown, and the plant size, design, location, and operating history. These specifics must be examined carefully before attempting to apply the results of this study to a different nuclear power station. Some efforts to examine the sensitivity of the study results to plant specifics such as size, radiation dose rates, etc., are presented in this report.

The study results are presented in two volumes. Volume 1 (Main Report) contains the results in summary form. Volume 2 (Appendices) contains the detailed data that support the results given in Volume 1. The supporting data are presented in a manner that facilitates their use for examining decommissioning actions other than those included in this study. 
○

$\bullet$ 


\section{CHAPTER 2}

\section{SUMMARY}

The results of this study sponsored by the U.S. Nuclear Regulatory Commission (NRC) to conceptually decommission a large boiling water reactor (BWR) power station are summarized in this chapter. The purpose of the study is to provide information on the available technology, the safety considerations, and the probable costs for decommissioning a large BWR power station after 30 full-power years of operation. The principal results are given, in brief, in the following paragraphs, with more-complete summaries presented in subsequent sections.

Immediate dismantlement of the reference BWR is estimated to cost $\$ 43.6$ million (in 1978 dollars), to require about 2 years for planning and preparation prior to final reactor shutdown, to require about $3-1 / 2$ years of active decommissioning following reactor shutdown, and to result in radiation doses to decommissioning workers of about 1845 man-rem.

Preparing the reference BWR for passive safe storage, safe storage for 30 years, and dismantlement after 30 years is estimated to cost a total of $\$ 58.8$ million (in 1978 dollars), to require about $1-1 / 2$ years for planning and preparation prior to final reactor shutdown, to require about 3 years to place the facility in passive safe storage, and to result in accummulated radiation doses to decommissioning workers of about 418 man-rem. Continuing care during safe storage is estimated to cost $\$ 75,000$ per year and would continue until the facility is dismantled. The cost of dismantling the reference BWR after passive safe storage is estimated to be somewhere between $\$ 36$ million and $\$ 26$ million, depending on the duration of the safe storage period, to require a time span equivalent to immediate dismantlement, and to result in radiation doses to decommissioning workers that range from 495 man-rem for dismantlement after 10 years of storage to a few man-rem after 50 years of storage. 
Entombing the reference BWR after removing the highly activated reactor vessel internals (scenario 1) is estimated to cost $\$ 40.6$ million (in 1978 dollars), to require about 2 years for planning and preparation prior to final reactor shutdown, to require about 4 years of active decommissioning following reactor shutdown, and to result in radiation doses to decommissioning workers of about 1684 man-rem. Entombing the reference BWR with the highly activated reactor vessel internals left in place (scenario 2) is estimated to cost $\$ 35$ million and to result in radiation doses to decommissioning workers of about 1573 man-rem. Scenario 2 is really a form of harderied safe storage, and dismantlement will be necessary to obtain unrestricted release of the property.

Costs of continuing care during entombment are estimated to be $\$ 40,000$ per year. These costs would continue until either the radioactivity can be shown to have decayed to unrestricted release levels, or until the facility is dismantled should an earlier release of the property become necessary.

No detailed estimates of cost and radiation dose are made for dismantlement of an entombed facility. However, it is anticipated that these parameters will have values similar to those for dismantlement following passive safe storage.

\subsection{STUDY BASES}

The major study bases are:

- The study must yield realistic and up-to-date results.

- The study is conducted within the framework of the existing regulations and regulatory guidance.

- The study is to evaluate decommissioning of an existing single-reactor facility.

- The study is based on 30 full-power years of plant operation.

- The estimated radiation dose rates throughout the plant are based on measured data from operating plants.

- Current and proven decommissioning technology and techniques are used. 
- The funding for decommissioning activities is available as necessary to complete the planned activities without fiscal constraint.

- A nuclear waste disposal facility is in operation.

- For decommissioning activities that immediately follow plant shutdown, the staff is composed of the former operations and maintenance personnel.

- Al1 materials whose radioactivity exceed unrestricted release levels are removed from the site before the site is released for unrestricted use.

- The performance of decommissioning activities is relatively trouble-free.

- The study conforms to ALARA occupational exposure philosophies.

- The costs are in 1978 dollars.

The results obtained in this study are specific to these major bases and to the specific assumptions that are derived from them and stated in the appropriate place in the study. Applying these results to situations where the conditions are different from those in this study could produce erroneous conclusions. The sensitivity of the study resuits to plant-specifics such as size, radiation dose rate, etc., is examined to provide guidance in the application of these results to other plants.

\subsection{DECOMMISSIONING ALTERNATIVES}

Decommissioning of a nuclear facility is defined as the measures taken following the end of the facility's operating life to ensure the protection of the public from any residual radioactivity or other hazards present in the facility. Three approaches to decommissioning are considered in this study:

- Dismantlement - The station is decontaminated and the radioactive materials are removed. Upon completion, the nuclear 7 icense is terminated and the property is released for unrestricted use.

- Safe Storage - The radioactive materials and contaminated areas are with Deferred Dismantlement decontaminated or secured and the structures and equipment are maintained as necessary to ensure the protection of the public from the residual radioactivity. During 
the period of safe storage, use of the property remains limited by the nuclear license. Eventual dismantlement is necessary if unrestricted release and license termination is desired.

- Entombment - The radioactive materials and contaminated areas are decontaminated and the nonreleasable materials are confined within a monolithic structure that provides integrity to ensure the protection of the public from the entombed radioactivity for a time period of sufficient length to permit the decay of the radioactivity to unrestricted release levels. During the period of entombment, the property is maintained as necessary and remains restricted in use by the nuclear license.

\subsection{DECOMMISSIONING EXPERIENCE}

A review of the documented cases of nuclear reactor decommissioning shows that while the decommissioned facilities were generally small and had operated for relatively short periods of time, the problems encountered tended to be common to all decommissioning undertakings. The review also shows that a wealth of experience exists within the nuclear industry regarding methods and equipment for accomplishing decommissioning, and that there are no major technical impediments to the successful decommissioning of a large BWR power station.

\subsection{REGULATORY GUIDANCE FOR DECOMMISSIONING}

In general, regulations are in place to cover decommissioning of the reference BWR. In some cases (i.e., security, safeguards, quality assurance), the existing regulations do not speak specifically to decommissioning, but they can readily be interpreted as being applicable.

The following suggestions are made for improving present regulations:

- Centralize or provide an index for all regulations that pertain to decommissioning. 
- Modify the existing regulations that apply to decommissioning to include reference to such centralized or indexed application.

- Clearly define the financial qualifications and responsibilities of the licensee for decommissioning.

- Specify which of the existing regulations governing allowable public radiation dose take precedence during the decommissioning of a lightwater reactor.

- More clearly define "high-level waste" (with respect to the highly radioactive reactor vessel components) and the associated disposal requirements.

- Provide a common, identifiable reference for acceptable residual radioactive contamination levels for unrestricted release of materials, structures, and sites.

- Specify the requirements for license renewal or extension, should such be necessary at the time of decommissioning.

\subsection{FINANCING DECOMMISSIONING}

The federal government currently has very little direct involvement in decommissioning financing considerations. NRC regulations simply require the applicant for an operating license to demonstrate the financial resources to cover the estimated costs of both operating and permanently shutting down the facility. However, the importance of financial assurance for decommissioning was recently recognized by the Congress of the United States in the Uranium Mi11 Tailings Control Act of 1978, which amends the Atomic Energy Act of 1954, providing explicit authority for the NRC to require an adequate bond, surety, or other financial arrangement by uranium mill licensees to ensure site cleanup and reclamation prior to license termination. Furthermore, the NRC is considering financial requirements within the broader context of an overall reevaluation of its policies on decommissioning nuclear facilities. 
Three principal financing alternatives for decommissioning a nuclear power station are considered in this study:

- a prepaid decommissioning reserve controlled by an outside entity

- an internal unfunded decommissioning reserve

- a funded reserve or sinking fund controlled by an outside entity.

A fourth alternative, payment of decommissioning costs from other revenues when the funds are required, is considered in less detail because it provides less assurance that funds will be available.

The revenue requirement for each of the financing alternatives is shown in Table 2.5-1, together with assumptions about tax treatment of the revenues. The results show that the revenue requirements are very sensitive to the tax treatment of those revenues. TABLE 2.5-1. $\begin{aligned} & \text { Revenue Requirements for the } \\ & \text { Financing Alternatives }(a)\end{aligned}$

\begin{tabular}{|c|c|c|c|}
\hline Financing Alternative & $\begin{array}{l}\text { Tax } \\
\text { Treatment } \\
\end{array}$ & $\begin{array}{l}\text { Annual Payments } \\
\text { (\$ millions) }\end{array}$ & $\begin{array}{l}\text { Total Payments } \\
\text { (\$ millions) }\end{array}$ \\
\hline Prepayment & Untaxed & 2.35 & 70.4 \\
\hline $\begin{array}{l}\text { Internal Unfunded } \\
\text { Reserve }\end{array}$ & $\begin{array}{l}\text { Untaxed } \\
\text { Taxed(b) }\end{array}$ & $\begin{array}{l}1.47 \\
2.72\end{array}$ & $\begin{array}{l}44.0 \\
87.5\end{array}$ \\
\hline Sinking Fund & $\begin{array}{l}\text { Untaxed } \\
\text { Taxed(b) }\end{array}$ & $\begin{array}{l}1.09 \\
2.01\end{array}$ & $\begin{array}{l}32.5 \\
60.2\end{array}$ \\
\hline Paid When Required & Untaxed & -- & 44.0 \\
\hline
\end{tabular}

(a) Estimated decommissioning cost $=\$ 44$ million, depreciation lifetime $=30$ years, effective interest rate on fund $=2 \% / \mathrm{yr}$, effective interest rate on borrowed capital $=4 \% / \mathrm{yr}$.

(b) Most likely situation regarding taxes.

\subsection{FACILITY AND SITE}

The reactor used as the reference facility in this study is the Washington Public Power Supply System's Nuclear Project Number 2, an 1155-MWe station with a Mark II containment system. The nuclear steam supply system 
is a direct-cycle boiling water reactor manufactured by the General Electric Company, and is generally representative of the current generation of large BWRs. The reference site used in these analyses is typical of a midwestern or middle southeastern river site. This site has been developed for use in a series of studies devoted to the decommissioning of nuclear fuel cycle facilities that is being performed for the NRC by Pacific Northwest Laboratory. Sufficient descriptive information is presented for both the facility and the site to permit the development of the detailed work plans, the costs estimates, and the safety assessments that are the results of this study.

\subsection{RADIONUCLIDE INVENTORY}

Levels of radioactivity in and radiation dose rates from activated reactor components, from contamination deposited throughout the plant, and from the site soil are calculated and/or derived from existing data. The radionuclides that are the principal contributors to occupational radiation exposure are: immediately after reactor shutdown and during the next 100 years, ${ }^{60} \mathrm{Co}$; and after 100 years, ${ }^{94} \mathrm{Nb}$. The amount of radioactivity present in the activated reactor vessel components at the time of reactor shutdown is calculated to be about 6.6 million curies. The calculated radiation dose rates of ${ }^{60}$ Co from the activated reactor components at reactor shutdown range from a maximum of $120,000 \mathrm{R} / \mathrm{hr}$ at the inner surface of the core shroud to $140 \mathrm{mR} / \mathrm{hr}$ at the reactor vessel outer surface. The calculated radiation dose rates from ${ }^{59} \mathrm{Ni}$ and ${ }^{94} \mathrm{Nb}$ have maximum values in the core shroud of about $70 \mathrm{mR} / \mathrm{hr}$ and $700 \mathrm{mR} / \mathrm{hr}$, respectively. Dose rates at locations throughout the facility range from several hundred $\mathrm{R} / \mathrm{hr}$ to a few $\mathrm{mR} / \mathrm{hr}$, based on a composite of data from operating plants.

Annual atmospheric releases from operating BWRs vary widely, depending on such specific plant factors as size, operating history, and gaseous effluent system design. For this study, the soil contamination levels and the mixtures of radionuclides on the site resulting from deposition of atmospheric releases from the plant during 40 years of normal operation are calculated from measured annual release information. 


\subsection{EXAMPLE ACCEPTABLE CONTAMINATION LEVELS FOR UNRESTRICTED USE OF THE BWR}

\section{PROPERTY}

A suggested methodology for determining acceptable residual radioactive contamination levels for unrestricted use of the decommissioned reference BWR facility and/or site is presented in this study, and example acceptable contamination levels are calculated. The methodology is based on the concept that no member of the public will be allowed to receive an annual dose in excess of a limit yet to be established by U.S. regulatory agencies. These example acceptable contamination levels are based on an assumed 50-mrem/yr limit. The effect of radioactive decay on these acceptable levels of residual radionuclides both in the facility and on the site is demonstrated by calculating these levels for the radionuclide mixture present at reactor shutdown and for the mixture present 10,30,50, and 100 years after shutdown.

For the facility, the acceptable levels of radioactivity are presented in units of surface activity $\left(\mu \mathrm{Ci} / \mathrm{m}^{2}\right)$. Soil contamination values are presented in units of radioactivity per gram of soil sample by assuming mixing of the radiation source with dry soil to depths of $10 \mathrm{~mm}$ and $150 \mathrm{~mm}$. After 40 years of normal BWR operation, the residual radioactive contamination is assumed to be mixed to a depth of $10 \mathrm{~mm}$ by natural processes. When the site is released, the residual radioactive contamination is assumed to be mixed to a depth of $150 \mathrm{~mm}$ as unrestricted activities begin.

A summary of the calculated example radioactive contamination levels that result in an annual dose of $50 \mathrm{mrem}$ to any organ of any individual is given in Table 2.8-1. 
TABLE 2.8-1. Summary of the Calculated Example Acceptable Residual Radioactive Contamination Levels for the Reference BWR Facility and Site

\begin{tabular}{|c|c|c|c|c|c|}
\hline \multirow[b]{3}{*}{ - } & \multirow{3}{*}{$\begin{array}{l}\text { Time Exposure } \\
\text { Begins } \\
\text { (Years after } \\
\text { Shutdown)(a) }\end{array}$} & \multirow[b]{3}{*}{$\begin{array}{l}\text { Limiting } \\
\text { Organ } \\
\end{array}$} & \multicolumn{3}{|c|}{$\begin{array}{l}\text { Acceptable Residual Contamination Levels } \\
\text { Corresponding to an Annual Dose of } 50 \text { mrem }\end{array}$} \\
\hline & & & Surface & Soil Cont & mination \\
\hline & & & $\frac{\text { Contamination }}{\left(\mu \mathrm{C} i / \mathrm{m}^{2}\right)}$ & $\frac{\text { Mixed to } 10 \mathrm{~mm}}{(\mathrm{pCi} / \mathrm{g})}$ & $\frac{\text { Mixed to } 0.15 \mathrm{~m}}{(\mathrm{pCi} / \mathrm{g})}$ \\
\hline \multirow[t]{2}{*}{ BWR Facility(b) } & 0 & Lungs & 0.55 & -- & -- \\
\hline & 100 & Bone & 0.82 & -- & -- \\
\hline \multirow[t]{2}{*}{ BWR Site } & 0 & Bone & 0.17 & 11 & 0.73 \\
\hline & 100 & Bone & 0.12 & 8.0 & 0.53 \\
\hline
\end{tabular}

(a) The time that continuous exposure begins.

(b) In the facility, a determination of acceptable surface radioactive contamination levels, based on the mixture of the radionuclides, is assumed to be used to help determine the necessary decommissioning procedures.

\subsection{RADIATION EXPOSURE ESTIMATES}

Estimates of accumulated occupational radiation dose are 1845 man-rem for immediate dismantlement, 1684 man-rem for entombment scenario 1 (removal of reactor vessel internals), 1573 man-rem for entombment scenario 2 (reactor vessel internals entombed), and 375 man-rem for placing the facility in passive safe storage, with an additional 7 to 10 man-rem for surveillance and maintenance during periods of continuing care of from 10 to 100 years. Radiation dose associated with deferred dismantlement depends on when the dismantlement takes place. Relatively little additional reduction in accumulated occupational radiation dose is estimated to result from deferring the dismantlement sequence beyond 30 years, and virtually no additional reduction results from deferment beyond 50 years.

The individual estimates of occupational radiation dose for the various decommissioning alternatives are summarized in Table 2.9-1.

Additional radiation dose is received by the transportation workers and by the general public as a result of transporting the spent fuel and the radioactive materials to disposal sites. These radiation doses are summarized in Table 2.9-2. 
Table 2.9-1. Summary of Estimated External Occupational Radiation Doses for Decommissioning the Reference BWR

\begin{tabular}{|c|c|c|c|c|c|c|}
\hline \multirow{3}{*}{$\begin{array}{c}\text { Start of } \\
\text { Decommissioning } \\
\text { (years after shutdown) }\end{array}$} & \multicolumn{6}{|c|}{ Estimated Radiation Dose to Decommissioning Personnel (man-rem) ${ }^{(a)}$} \\
\hline & \multirow{2}{*}{$\begin{array}{c}\text { Immediate } \\
\text { Dismantlement }\end{array}$} & \multirow{2}{*}{$\begin{array}{l}\text { Preparations for } \\
\text { Passive Safe Storage }\end{array}$} & \multirow{2}{*}{$\begin{array}{c}\text { Continuing } \\
\text { Care } \\
\end{array}$} & \multicolumn{2}{|c|}{ Entombment } & \multirow{2}{*}{$\begin{array}{c}\text { Deferred } \\
\text { Dismantlement }\end{array}$} \\
\hline & & & & Scenario 1 & Scenario 2 & \\
\hline 0 & 1845 & 375 & -- & 1684 & 1573 & \\
\hline 10 & $=$ & -- & 1.3 & -- & -- & 495 \\
\hline 30 & -- & -- & 6.5 & -- & -- & 36 \\
\hline 50 & -- & -- & 10.0 & -- & -- & 3 \\
\hline 100 & -- & -- & 10.0 & - & -- & $<1$ \\
\hline
\end{tabular}

(a)Total dose for passive safe storage with dismantlement deferred for 30 years is the sum of $(375+6.5+36)$ man-rem.

TABLE 2.9-2. Radiation Dose from Transport of Radioactive Materials from Decommissioning

Radiation Doses from Transport (man-rem) (a)

\begin{tabular}{cc} 
Preparations & $\begin{array}{c}\text { Pntombment } \\
\text { Passive Safe } \\
\text { Storage }\end{array}$ (Scenario 1) (Scenario 2) \\
\hline
\end{tabular}

Occupational :

Truck Transport $\quad 110$

$\begin{array}{lllll}\text { Rail Transport } & -\frac{5.4}{120} & \frac{5.4}{28} & \frac{5.4}{75} & \frac{5.4}{56}\end{array}$

Public:

\begin{tabular}{ccccc} 
Truck Transport & 10 & 2.2 & 6.7 & 4.9 \\
Rail Transport & $\underline{0.5}$ & $\underline{0.5}$ & $\frac{0.5}{7.2}$ & $\frac{0.5}{5.4}$ \\
\hline Totals & 11 & 2.7 & $\frac{7.2}{4}$
\end{tabular}

(a)A11 values are rounded to two significant figures.

(b) For deferred dismantlement, these values are reduced in proportion to the decay of ${ }^{60}$ activity during the safe storage period. 


\subsection{DECOMMISSIONING COSTS}

A11 costs are given in terms of 1978 dollars, with $25 \%$ contingencies included.

Immediate dismantlement is estimated to cost $\$ 43.6$ million. The major contributors to the total cost of immediate dismantiement are summarized in Table 2.10-1. The cost for shipment and disposal of radioactive materials is about $25 \%$ of the total decommissioning cost. About $50 \%$ of the total decommissioning cost is due to staff labor. Energy, equipment, and supply costs constitute about 10,6 , and $5 \%$, respectively, of the total dismantlement cost.

TABLE 2.10-1. Summary of Estimated Costs for Immediate Dismantlement

Cost Category

Disposal of Radioactive Materials Neutron-Activated Materials Contaminated Materials Radioactive Wastes

Total Disposal Costs

Staff Labor

Energy

Special Tools and Equipment

Miscellaneous Supplies

Specialty Contractors

Nuclear Insurance

License Fees

Subtotal

Contingency $(25 \%)$

Total, Immediate Dismantlement Costs

Other Possible Costs

Spent Fuel Shipment

Facility Demolition and Site Restoration Deep Geologic Disposal of Highly Activated Materials

Fuel Channel Disposal

Subtotal

Contingency (25\%)

Total, Other Possible Costs

Estimated Costs
$(\$$ millions $)(a, b)$ $\begin{gathered}\text { Percent of } \\ \text { Total }\end{gathered}$

2.300

4.909

1.469

\begin{tabular}{rr}
8.678 & 24.9 \\
17.561 & 50.4 \\
3.519 & 10.1 \\
2.016 & 5.8 \\
1.859 & 5.3 \\
0.356 & 1.0 \\
0.800 & 2.3 \\
0.051 & 0.1 \\
\hline 34.840 & 100.0 \\
8.710 & \\
\hline 43.550 &
\end{tabular}

3.788

13.244

0.848

0.617

18.497

4.624

23.121

(a) Costs adjusted to early 1978.

(b) The number of significant figures shown is for computational completeness and does not imply accuracy to the nearest $\$ 1000$. 
Other possible costs, which include shipment of spent fuel, disposal of fuel channels, disposal of highly activated materials in deep geologic disposal, and demolition of the decontaminated facility, total an additional $\$ 23.1$ million.

Preparing the reference BWR for passive safe storage is estimated to cost $\$ 21.3$ million. The major contributors to the total cost of preparations for passive safe storage are summarized in Table 2.10-2. The principal cost item is staff labor, contributing about $66 \%$ of the total. Energy, supplies, and disposal of radioactive wastes contribute about 13,8 , and $7 \%$, respectively, to the total cost.

TABLE 2.10-2. Summary of Estimated Costs for Preparations for Passive Safe Storage

Cost Category

Disposal of Radioactive Materials (Radioactive Wastes)

Staff Labor

Energy

Special Tools and Equipment Miscellaneous Supplies Specialty Contractors

Nuclear Insurance License Fees

Subtotal

Contingency (25\%)

Total, Preparations for Passive

Safe Storage Costs

Other Possible Costs

Spent Fuel Shipment

Fuel Channel Disposal

\section{Subtotal}

Contingency (25\%)

Total, Other Possible Costs
Estimated Costs (\$ millions) $(a, b)$

Percent of Tota 7

\begin{tabular}{rr}
1.216 & 7.1 \\
11.254 & 66.7 \\
2.122 & 12.5 \\
0.351 & 2.7 \\
1.361 & 8.0 \\
0.196 & 1.2 \\
0.500 & 2.9 \\
0.038 & 0.2 \\
\hline 17.038 & 100.0 \\
4.260 & \\
\hline
\end{tabular}

21.298

3.788

0.617

4.405

1.101

5.506

(a) Costs adjusted to early 1978.

(b) The number of significant figures shown is for computational completeness and does not imply accuracy to the nearest $\$ 1000$. 
The cost of continuing care during passive safe storage is estimated to be $\$ 75,000$ per year.

The cost of deferred dismantlement following passive safe storage for intervals of $10,30,50$, and 100 years after final reactor shutdown is estimated in constant 1978 dollars to be $\$ 36$ million, $\$ 36$ million, $\$ 26$ million and $\$ 26$ million, respectively. The lesser costs after the longer intervals are the result of having less contaminated material for packaging, shipment, and burial due to decay of the radionuclides.

Entombing the reference BWR via scenario 1 (removal and disposal of reactor vessel internals) is estimated to cost $\$ 40.6$ million. The major contributors to the total cost of entombment are summarized in Table 2.10-3. The principal cost item is staff labor, contributing almost $56 \%$ of the total for scenario 1. Disposal of radioactive materials, energy, equipment, and supplies contribute about $18,12,6$, and $6 \%$, respectively, to the total cost.

\section{TABLE 2.10-3. Summary of Estimated Costs Entombment}

\begin{tabular}{|c|c|c|c|c|}
\hline Cost Category & $\begin{array}{r}\text { Entombment } \\
\text { Estrmated Costs } \\
\text { (\$ millions) }(\mathrm{a}, \mathrm{b}) \\
\end{array}$ & $\begin{array}{l}\text { enario } 1 \\
\text { Percent of } \\
\text { Total }\end{array}$ & $\begin{array}{l}\text { Entombment Sce } \\
\text { Estimated Costs } \\
(\$ m 111 \text { ions })(\mathrm{a}, \mathrm{b})\end{array}$ & $\begin{array}{l}\text { nario } 2^{(c)} \\
\text { Percent of } \\
\text { Total }\end{array}$ \\
\hline $\begin{array}{l}\text { Disposal of Radioactive Materials } \\
\text { Neutron-Activated Materials } \\
\text { Contaminated Materials } \\
\text { Radroactive Wastes }\end{array}$ & $\begin{array}{l}2394 \\
1 \quad 846 \\
1 \quad 469 \\
\end{array}$ & & $\begin{array}{ll}0 & \\
1 & 992 \\
1 & 469 \\
\end{array}$ & \\
\hline Total Disposal Costs & 5709 & 176 & $\overline{3} 461$ & 124 \\
\hline $\begin{array}{l}\text { Staff Labor } \\
\text { Energy } \\
\text { Special Tools and Equipment }\end{array}$ & $\begin{array}{rr}18 & 095 \\
3 & 775 \\
2 & 016\end{array}$ & $\begin{array}{rr}55 & 7 \\
11 & 6 \\
6 & 2\end{array}$ & $\begin{array}{rl}16 & 999 \\
3 & 775 \\
0 & 866\end{array}$ & $\begin{array}{rr}60 & 8 \\
13 & 5 \\
3 & 1\end{array}$ \\
\hline $\begin{array}{l}\text { Miscellaneous Supplies } \\
\text { Specialty Contractors } \\
\text { Nuclear Insurance } \\
\text { License Fees }\end{array}$ & $\begin{array}{ll}1 & 859 \\
0 & 172 \\
0 & 800 \\
0 & 039 \\
\end{array}$ & $\begin{array}{ll}5 & 7 \\
0 & 5 \\
2 & 5 \\
0 & 1 \\
\end{array}$ & $\begin{array}{ll}1 & 859 \\
0 & 172 \\
0 & 800 \\
0 & 039 \\
\end{array}$ & $\begin{array}{ll}6 & 6 \\
0 & 6 \\
2 & 9 \\
0 & 1 \\
\end{array}$ \\
\hline Subtotals & 32465 & 1000 & 27971 & 1000 \\
\hline Contingencies (25) & 8116 & & $\underline{6} 993$ & \\
\hline Tota1s, Entombment Costs & 40581 & & 34964 & \\
\hline Annual Continuing Care Costs & 0040 & & 0040 & \\
\hline Other Possible Costs & & & & \\
\hline $\begin{array}{l}\text { Spent Fuel Shipment } \\
\text { Facility Demolition and Site Restoration } \\
\text { Deep Geological Disposal of Highly Activated } \\
\text { Materials } \\
\text { Fuel Channel Disposal }\end{array}$ & $\begin{array}{ll}3 & 788 \\
8 & 059 \\
0 & 495 \\
0 & 617 \\
\end{array}$ & & $\begin{array}{ll}3 & 788 \\
8 & 059 \\
0 & \\
0 & 617 \\
\end{array}$ & \\
\hline Subtotals & 12959 & & 12464 & \\
\hline Contringencies $(25 \%)$ & 3240 & & 3116 & \\
\hline Totals, Other Possible Costs & 16199 & & 15580 & \\
\hline
\end{tabular}

\footnotetext{
(a) Costs adjusted to early 1978
(b) The number of significant figures shown is for computational completeness and does not imply accuracy to the nearest $\$ 1000$

(c) Scenario 2 w11l require eventual dismantiement
} 
Entombment scenario 2 (reactor vessel internals retained within the entombment structure), which is really a form of hardened safe storage, is estimated to cost $\$ 35$ million.

The cost of continuing care during entombment is estimated to be $\$ 40,000$ per year for either scenario 1 or scenario 2.

No detailed cost estimates are developed for dismantlement of an entombed reactor since under scenario 1 the intent is to leave the structure intact until the radioactivity has decayed to release levels. Dismantlement is required under scenario 2, and it is anticipated that the costs would be similar to the costs of dismantlement following passive safe storage.

The total cost in constant 1978 dollars for each of the decommissioning alternatives is summarized in Table 2.10-4.

TABLE 2.10-4. Total Estimated Costs for Possible Decommissioning Alternatives

\begin{tabular}{|c|c|c|c|c|c|c|}
\hline \multirow[b]{2}{*}{$\begin{array}{l}\text { Decommissioning } \\
\text { Alternative }\end{array}$} & \multicolumn{6}{|c|}{ Decommissioning Costs $(\$ \text { millions })^{(\mathrm{a}, \mathrm{b})}$} \\
\hline & Number & $\frac{\text { of Years Afte }}{0}$ & $\frac{r \text { Reactor }}{10}$ & $\frac{r \text { Shutdor }}{30}$ & $\frac{\text { wn Disman }}{50}$ & $\frac{1 \text { tlement is Deferred }}{100}$ \\
\hline $\begin{array}{l}\text { Immediate } \\
\text { Di smantl ement }\end{array}$ & & 43.6 & -- & -- & -- & -- \\
\hline $\begin{array}{l}\text { Preparations for } \\
\text { Passive Safe Storage }\end{array}$ & & 21.3 & 21.3 & 21.3 & 21.3 & 21.3 \\
\hline Continuing Care & & -- & 0.6 & 2.1 & 3.6 & 7.4 \\
\hline $\begin{array}{l}\text { Deferred } \\
\quad \text { Dismantlement }\end{array}$ & & -- & 35.5 & 35.5 & $26.4^{(c)}$ & $26.4(c)$ \\
\hline Total Cost & & -- & 57.4 & 58.9 & 51.3 & 55.0 \\
\hline $\begin{array}{l}\text { Entombment } \\
\quad \text { (Scenario 1) } \\
\text { (Scenario 2) }\end{array}$ & & $\begin{array}{l}40.6 \\
35.0\end{array}$ & $\begin{array}{l}40.6 \\
35.0\end{array}$ & $\begin{array}{l}40.6 \\
35.0\end{array}$ & $\begin{array}{l}40.6 \\
35.0\end{array}$ & $\begin{array}{l}40.6 \\
35.0\end{array}$ \\
\hline Continuing Care & & -- & 0.3 & 1.1 & 1.9 & 3.9 \\
\hline $\begin{array}{l}\text { Deferred } \\
\text { Dismantlement }\end{array}$ & & -- & 230 & 230 & $\simeq 20$ & $\simeq 20$ \\
\hline $\begin{array}{l}\text { Total cost } \\
\left(\begin{array}{lll}\text { Scenario } & 1) \\
(\text { Scenario } & 2\end{array}\right)\end{array}$ & & $\begin{array}{l}-- \\
--\end{array}$ & $265^{--}$ & $n_{6 \overline{6}}^{--}$ & $257^{--}$ & $\begin{aligned} & 44.5^{(e)} \\
& 59\end{aligned}$ \\
\hline
\end{tabular}

(a) Values include a $25 \%$ contingency.

(b) Values are in constant 1978 dollars.

(c) These reduced values result from lesser amounts of contaminated materials for burial in a licensed disposal site.

(d) Order of magnitude estimate, based on engineering judgement, applies only to entombment scenario 2.

(e) It is assumed that the entombed radioactive material decays to the unrestricted release level in 100 years. 


\subsection{OCCUPATIONAL AND PUBLIC SAFETY}

Radiological and nonradiological safety impacts from normal decommissioning operations and from potential accidents are identified and evaluated for the reference BWR for the immediate dismantlement, passive safe storage with deferred dismantlement, and entombment decommissioning alternatives. The safety evaluation includes consideration of radiation dose to the public from normal operations and postulated accidents and from potential chemical pollutants. The safety evaluation utilizes current data and methodology, along with engineering judgment when necessary, to estimate the required input information and the resulting safety impacts. The approach used to evaluate all the safety aspects of a particular decommissioning activity is believed to be conservative.

The results of the safety evaluation of normal decommissioning operations are summarized in Table 2.11-1. The principal radiation dose to the public results from the transport of radioactive materials from the reactor station to disposal facilities. The estimated dose to the public resulting from decommissioning operations is extremely small.

TABLE 2.11-1. Summary of Safety Analysis for Decommissioning the Reference BWR

\begin{tabular}{|c|c|c|c|c|c|c|c|c|c|}
\hline \multirow{2}{*}{$\begin{array}{c}\text { Type of } \\
\text { Safety Concern }\end{array}$} & \multirow{2}{*}{$\begin{array}{c}\text { Source of } \\
\text { Safety Concern }\end{array}$} & \multirow[b]{2}{*}{ Units } & \multirow{2}{*}{$\begin{array}{l}\text { Immedrate } \\
\text { Dismantlement }\end{array}$} & \multicolumn{2}{|c|}{ Entombment } & \multicolumn{4}{|c|}{$\begin{array}{c}\text { Passive Safe Storage with Deferred } \\
\text { Dismantlement After }\end{array}$} \\
\hline & & & & Scenario 1) & (Scenario 2) & 10 Years & 30 Years & 50 Years & 100 Years \\
\hline \multicolumn{10}{|c|}{ Public Safety ${ }^{(a)}$} \\
\hline \multirow[t]{4}{*}{ Radiation Dose } & $\begin{array}{l}\text { Decommissioning } \\
\text { Operations }(b)\end{array}$ & man-rem & 0.05 & 0.04 & 0.04 & $<0.05$ & $<0.05$ & $<0.05$ & $<0.05$ \\
\hline & Transportation & man-rem & 11 & 7.2 & 5.9 & 5.6 & 2.9 & 2.7 & 2.7 \\
\hline & Continuing Care & man-rem & -- & neg. (c) & neg. (c) & neg. (c) & neg. (c) & neg. (c) & neg. (c) \\
\hline & onal Safety & & & & & & & & \\
\hline \multirow[t]{3}{*}{$\begin{array}{l}\text { Serious Lost-time } \\
\text { Injuries }\end{array}$} & $\begin{array}{l}\text { Decommissioning } \\
\text { Operations }\end{array}$ & total no. & 6.7 & 6.5 & 6.5 & 9.6 & 9.6 & 9.6 & 9.6 \\
\hline & Transportation & total no. & 1.2 & 0.8 & $<0.8$ & 15 & 1.5 & 15 & 15 \\
\hline & Contrnuing Care & total no. & $\cdots$ & -- & -- & 0.06 & 0.18 & 0.30 & 0.61 \\
\hline \multirow[t]{3}{*}{ Fatalities } & $\begin{array}{l}\text { Decommissioning } \\
\text { Operations }\end{array}$ & total no. & 0.038 & 0.039 & $<0.039$ & 0.058 & 0058 & 0.058 & 0058 \\
\hline & Transportation & total no. & 0.072 & 0.047 & $<0 \quad 047$ & 0.087 & 0.087 & 0.087 & 0.087 \\
\hline & Continuing Care & total no. & -- & -- & -- & 0.00061 & 0.0018 & 0.0031 & 0.0061 \\
\hline \multirow[t]{3}{*}{ Radiation Dose } & $\begin{array}{l}\text { Decommissioning } \\
\text { Operations }\end{array}$ & man-rem & 1845 & 1684 & 1573 & 871 & 418 & 388 & 386 \\
\hline & Transportation & man-rem & 120 & 75 & 56 & 60 & 30 & 28 & 28 \\
\hline & Continuing Care & man-rem & - & -- & -- & 1.3 & 6.5 & 10.0 & 10.0 \\
\hline $\begin{array}{l}\text { (a) Radiation doses } \\
\text { (b) } 50-y r \text { comm tted } \\
\text { (c) neg. = negligib } \\
\text { in detall, but }\end{array}$ & $\begin{array}{l}\text { from postulated a } \\
\text { dose equivalent } t \\
\text { le. Radiation dos } \\
\text { are expected to be }\end{array}$ & $\begin{array}{l}\text { accidents a } \\
\text { to the lung } \\
\text { ses to the } \\
\text { e signjfica }\end{array}$ & $\begin{array}{l}\text { e not included } \\
\text { for the total } \\
\text { ublic from nor } \\
\text { tly smaller th }\end{array}$ & $\begin{array}{l}\text { population wi } \\
\text { mal continuing } \\
\text { ian those from }\end{array}$ & $\begin{array}{l}\text { thin an 80-km } \\
\text { care activit] } \\
\text { decommissionin }\end{array}$ & $\begin{array}{l}\text { radius of } \\
\text { les are not } \\
\text { ig operatio }\end{array}$ & $\begin{array}{l}\text { the site } \\
\text { analyzed } \\
\text { ons. }\end{array}$ & & \\
\hline
\end{tabular}


Less than 10 lost-time injuries from industrial-type accidents are predicted to occur during the decommissioning effort, with one additional injury predicted to result from transportation operations. Essentially no fatalities are predicted to occur as a result of decommissioning operations, including transportation.

\subsection{COMPARISON WITH OTHER STUDIES}

A review of four studies on decommissioning of BWR power stations (two from Germany, the 1976 AIF study, and a 1977 analysis by the Washington Public Power Supply System) shows that it is extremely difficult to compare these studies because the level of detail and the basic assumptions vary markedly between them. The cost estimates for immediate dismantlement from these studies range from $\$ 31$ million to $\$ 100$ million in 1978 dollars, with the two German studies estimating the highest costs.

\subsection{FACILITATION OF DECOMMISSIONING}

A number of techniques for facilitating decommissioning are presented and examined for their impact on cost and occupational radiation dose during reactor operation and maintenance, as well as during immediate dismantlement. It is concluded that the techniques that are most beneficial are those that reduce cost and radiation dose during operations and maintenance, since many more opportunities for reducing cost and dose occur over the operating 1ife of the plant than occur during decommissioning.

\subsection{IMPACTS OF ALTERNATE STUDY BASES}

Analyses of the sensitivity of cost and radiation dose to such factors as plant size, radiation dose rate, disposal-site charges, etc., are developed and presented.

Scaling factors are developed for use in estimating costs and occupational radiation dose for decommissioning BWR power stations whose sizes are smaller than the reference BWR. An overall scaling factor (OSF) is derived that is a function of the plant power rating (PPR) in thermal megawatts: 


$$
\text { OSF }=0.324+\left(2.035 \times 10^{-4}\right) P P R
$$

The product of this scaling factor (evaluated for the power rating of the smaller plant) and the cost for decommissioning the reference BWR yields a reasonable estimate of the cost for decommissioning the smaller plant.

If the radiation dose rates throughout the reference plant are three times greater than assumed in this study, occupational radiation doses are estimated to more than double, and the cost of immediate dismantlement and entombment, if accomplished in the same manner as before, is estimated to increase by over $\$ 6$ million. A more extensive chemical decontamination program would minimize the impact of higher initial radiation dose rates from piping and equipment.

The total decommissioning cost is not very sensitive to disposal rates at a shallow-land burial facility or at a deep geologic waste storage facility. Doubling the burial ground charges is estimated to increase the total decommissioning cost by less than $9 \%$, and tripling the deep geologic disposal charges is estimated to increase the total decommissioning cost by about $6 \%$.

The impact of the different containment structure designs (Mark I, II, and III) on decommissioning costs is estimated to be insignificant.

\subsection{CONCLUSIONS AND RECOMMENDATIONS}

Decommissioning of a large BWR power station is technically feasible with present-day technology. Further development of special equipment such as the plasma-arc torch, the arc saw, and sophisticated remote-handling equipment could lead to reductions in both cost and occupational radiation exposure.

Existing regulations appear to cover decommissioning. However, some modifications and/or additions that speak specifically to the requirements for decommissioning would be helpful. Centralization or an indexing of regulations that apply to decommissioning would also be helpful.

The estimated occupational radiation dose resulting from decommissioning is, at most, roughly equivalent to the dose resulting from about three or four typical refueling and maintenance outages, and thus does not appear to be 
prohibitively large. The impact of decommissioning on the safety of the public is small, with no significant risk to the public identified.

To put the various decommissioning alternatives in perspective, it is useful to examine the estimated costs and occupational radiation doses associated with achieving unrestricted release of the facility and the site. For the safe storage and entombment alternatives, it is assumed that the release takes place about 100 years after final reactor shutdown, The estimated cost and radiation dose for each alternative is given in Table 2.15-1. From the table it is seen that immediate dismantlement costs the least but results in the greatest radiation dose. Passive safe storage with deferred dismantlement has a significantly higher cost but a much reduced radiation dose. Neither of the entombment scenarios is a significant improvement over immediate dismantlement. The cost of having the property unavailable for unrestricted use for 100 years is not included in these comparisons, since the complexity of estimating that cost is beyond the scope of this study.

TABLE 2.15-1. Comparison of Costs and Radiation Doses for Decommissioning the Reference BWR Via the Various Alternatives

\begin{tabular}{lcc}
$\begin{array}{c}\text { Decommissioning } \\
\text { Alternative }\end{array}$ & $\begin{array}{c}\text { Cost } \\
\text { (millions, 1978 dollars) }\end{array}$ & $\begin{array}{c}\text { Occupational Radjation } \\
\text { Dose (man-rem) }\end{array}$ \\
\cline { 1 - 2 } $\begin{array}{c}\text { Immediate } \\
\text { Dismantlement }\end{array}$ & 43.6 & 1965 \\
$\begin{array}{c}\text { Passive Safe } \\
\text { Storage }\end{array}$ & $55.0(\mathrm{~b}, \mathrm{c})$ & 414 \\
$\begin{array}{c}\text { Entombment } \\
\text { (Scenario 1) }\end{array}$ & & \\
(Scenario 2) & $44,5(\mathrm{~b}, \mathrm{~d})$ & 1759 \\
& $\sim 59(\mathrm{~b}, \mathrm{c})$ & 1629
\end{tabular}

(a) Doses include decommissioning and transportation workers.
(b) Cost includes maintenance and surveillance for 100 years.
(c) Cost includes dismantlement after 100 years.
(d) No dismantlement assumed.

The acceptability of disposal of highly activated and/or long-lived radioactive materials by burial in a shallow-land burial facility is under consideration by the NRC and needs to be determined. If placement of these materials 
in a deep geologic disposal facility similar to that postulated for high-level radioactive wastes is required in the future, decommissioning costs will be increased by about $\$ 1$ million.

If the bulk of the nonactivated, contaminated stainless steel and nonferrous metals can be decontaminated to levels sufficiently low to permit unrestricted use, additional savings can be realized. However, the appropriate definitions of the amount of radioactivity that would be permitted on such materials when released for unrestricted use are not presently available.

Certain types of data useful to decommissioning analyses are essentially nonexistent at this time. Measurements on activated stainless steel that has been irradiated for an extended period of time (>10 years) to determine the growth of such long-lived radionuclides as ${ }^{59} \mathrm{Ni}$ and ${ }^{94} \mathrm{Nb}$ would be valuable for confirmation of calculations. Similarly, measurements of the growth of radionuclides in irradiated concrete would be helpful in evaluating the radiation dose rates that might be encountered from the activated reactor shield. In particular, the levels of ${ }^{152} \mathrm{Eu}$ and ${ }^{154} \mathrm{Eu}$ resulting from trace amounts of europium present in the concrete are important contributors to the total radiation dose rate from the concrete. In addition, studies to determine the actual levels of radioactivity on the soil surfaces surrounding operating reactor facilities would help to characterize in a realistic manner the residual radioactivity that might be present after 40 years of operation, and would help to quantify the decontamination effort that might be required to release the site for unrestricted use. Selected research programs in these areas are in progress, sponsored by the NRC.

Careful attention during the design and construction phase of a reactor project to simplify the problems of eventual decommissioning would be effective in reducing decommissioning costs and occupational radiation exposure. 
1

• 


\section{CHAPTER 3}

\section{STUDY APPROACH AND BASES}

This chapter contains a description of the approach taken and the major bases for the results in this study. It should be recognized that the study results are specific to this approach and to these major bases, and any application of different approaches or bases could lead to significantly different results.

\subsection{STUDY APPROACH}

The initial effort is to develop a plan with which to accomplish the objective of this study, which is to provide an analysis of the technology, safety and costs of decommissioning a reference BWR power station at the end of its operating life. The plan is developed by a team of key personnel with expertise in the primary areas of interest in the study. The areas of expertise include nuclear reactor station design and operation, decommissioning techniques, chemical decontamination, radiological and chemical toxicant regulations, radiological and industrial safety analyses, health physics, and costbenefit estimating and analyses. The study is then carried out by the same staff or by staff with similar backgrounds.

The first step in conducting the study is to select the reference facility and to characterize it in sufficient depth to perform an engineering and safety analysis of its decommissioning. An existing plant is selected as the reference for this analysis. The reference facility is placed on a generic site, which is also being used in similar and related studies of other fuel cycle facilities. A detailed description of the selected facility is compiled, including information on plant equipment and material sizes, volumes and weights. Predecommissioning conditions for the plant and site are defined, including residual radionuclide inventories, radiation dose rates, and radioactive contamination levels.

The feasible decommissioning modes (i.e., dismantlement, various forms of safe storage, and entombment) and their site-use limitations following 
decommissioning (i.e., restricted use and unrestricted use) are identified. Related regulatory guidance is reviewed, summarized, and used as an aid and basis in the study.

Methods for nuclear facility decommissioning are determined. The methods specified in this study are selected on the basis of engineering judgement, while maintaining a balance of safety and cost. For each of the selected decommissioning modes, tasks and task schedules are developed to conceptually decommission the reference facility by using the methods specified.

Safety analyses are performed for each of the selected decommissioning modes. These analyses include radiological and chemical exposures to the workers and the public from normal decommissioning operations and from potential accidents. Nonradiological industrial accidents to workers are also estimated. The safety analyses use established data and methodology to estimate the release mechanisms, dispersion, and pathways and exposure modes of the released materials.

Costs of decommissioning are estimated for labor, materials, equipment, packaging, transportation, disposal, and, where applicable, continuing care. The estimation data used in this study are identical, insofar as possible, to those used in a previous pressurized water reactor decommissioning study. This provides a basis for comparison of the two studies.

Alternatives for financing decommissioning are examined and compared using the costs from this study.

The primary emphasis and first thrust of this study is on the immediate dismantlement mode of decomissioning; the safe-storage and entombment analyses are, in nature, outgrowths of the dismantlement analysis, in that they rely largely on data generated for dismantlement. For dismantlement, once the reference facility is defined in sufficient detail (including the radiation dose rates and radionuclide inventories at final shutdown) and the radioactivematerial packaging and disposal requirements are defined, the analysis proceeds in the following general manner:

1. Define the decontamination, packaging, and sectioning requirements for each piece of contaminated equipment or material. 
2. Determine the amenable method and resultant time of sectioning.

3. Specify the staff required to perform the tasks.

4. Determine the schedule and sequence of the tasks.

5. Calculate the resultant costs and assess the safety of the tasks.

Following completion of the dismantlement analysis, the analyses for the other two decommissioning modes are undertaken.

\subsection{STUDY BASES}

The study is intended to provide decommissioning information useful to regulators, designers, and operators of BWRs. The study bases are established for all aspects of the study to ensure that the study objective is achieved. The study bases have major impacts on the issues of decommissioning safety, cost, and time. Many aspects of decommissioning may change, depending on each specific facility design, shutdown conditions, and residual contamination levels. The bases used in this study must therefore be carefully examined before the results can be applied to a different facility. These study bases are:

1. The study must yield realistic and up-to-date results. This primary basis is a requisite to meeting the objectives of the study, and provides the foundation for most of the other bases.

2. The study is conducted within the framework of the existing regulations and regulatory guidance. No assumptions are made regarding what future regulatory requirements or guidance might be. It is recognized that future regulatory considerations could have significant impacts on the results of this study.

3. The study evaluates an existing single-reactor facility. This is required to meet the study objectives and the primary basis stated earlier. The facility selected as the reference for study, the WPPSS Nuclear Project No. 2 , satisfies this condition, since it is a single-reactor power station and is basically typical of the current generation of BWR stations. (Decommissioning a multiple-reactor site may be quite different.) 
4. The plant operates for 30 effective full-power years.

5. The estimated radiation dose rates throughout the station are based on measured data from operating reactor stations. These data are measured during refueling and/or maintenance outages.

6. Current and proven decommissioning technology and techniques are used. Where developmental techniques are called for in this study, they are in an advanced state of development and are believed to be ready for the specific application.

7. The financing for decommissioning activities is available as necessary to complete the planned activities without fiscal constraint. Various funding options are available, but the appropriate method should be chosen prior to plant operation to permit the acquisition of sufficient funds before or during decommissioning.

8. A nuclear waste disposal facility is in operation. The existence of an operable disposal facility is requisite to most decommissioning modes.

9. For decommissioning activities immediately following plant shutdown, the staff is drawn largely from the operating personnel of the station, who are very familiar with the facility and its systems.

10. Al1 materials whose radioactivity exceed unrestricted release levels are removed from the site before the site is released for unrestricted use.

11. The performance of decommissioning activities is relatively trouble-free. No scheduling or cost allowances are made for unforeseen events that might impede the conduct of the work, other than for the unavoidable inefficiencies associated with radiation work. This assumption may lead to optimistic results, but is believed to be achievable with good planning and preparation.

12. Decommissioning radiation protection philosophies and techniques conform to the principle of keeping occupational radiation doses As Low As is Reasonably Achievable (ALARA).

13. Costs are in 1978 dollars. 
From these major study bases, more specific bases and assumptions are derived for specific study areas. These specific bases and assumptions are presented in their respective report sections.

Some plausible alternatives to these major study bases are also analyzed for their impacts on decommissioning costs and radiation doses. The five "alternative study bases" analyzed are: 1) different BWR plant sizes, 2) increased radiation dose rates, 3) different contractual arrangements, 4) increased nuclear waste disposal charges, and 5) different BWR containment designs. 


\section{REFERENCES}

1. R. I. Smith, G. J. Konzek and W. E. Kennedy, Jr., Technology, Safety and Costs of Decommissioning a Reference Pressurized water Reactor Power Station, NUREG/CR-0130, Appendix I, U.S. Nuclear Regulatory Commission Report by Pacific Northwest Laboratory, June 1978.

ॠ Available for purchase from the NRC/GPO Sales Program, U.S. Nuclear Regulatory Commission, Washington, D.C. 20555, and the National Technical Information Service, Springfield, Virginia 22161. 
DECOMMISSIONING: ALTERNATIVES, CONSIDERATIONS

AND EXPERIENCE

Once a nuclear reactor reaches the end of its useful life, it must be decommissioned (i.e., retired from service in a condition such that risk to the public is within acceptable bounds). A number of conditions satisfy the requirements of decommissioning. These conditions range from minimal cleanup and subsequent physical security under appropriate licensing restrictions, to complete cleanup and removal of all radioactivity and release of the plant from all licensing restrictions. This chapter deals with the alternatives and the considerations for decommissioning, as well as with the experience from past decommissionings.

\subsection{ALTERNATIVES FOR DECOMMISSIONING}

Three alternatives can be used for decommissioning reactor facilities: dismantlement, safe storage, and entombment. Dismantlement, either immediate or after an extended safe storage period, permits termination of the owner's facility operating license, while safe storage and entombment require the continuance of an amended version of the license and are not necessarily complete modes. (The amended operating license, allowing the licensee to possess but not operate the facility, is termed a "possession-only" license.) (1) A summary of the characteristics of each of these alternatives is presented in Table 4.1-1. Each of these alternatives, as applied to the reference BWR, is defined and discussed in this section.

\subsubsection{Dismantlement}

Dismantlement is the removal from the site of all materials having radioactivity levels greater than permitted for unrestricted use of the property. Therefore, under present regulatory requirements, dismantlement is the only decommissioning alternative that allows termination of the facility operating license in a finite time period. Demolition and removal of the structure following dismantlement is at the option of the owner and local government agencies (not the NRC). Dismantlement of the reference BWR requires removal 
TABLE 4.1-1. Characteristics of the Various Decommissioning Alternatives

\begin{tabular}{|c|c|c|c|}
\hline Alternative & Facility Status & & Plant/Site \\
\hline Dismantlement & $\begin{array}{l}\text { Plant Equipment - removed if radioactive } \\
\text { Continuing Care Staff - none } \\
\text { Security - none } \\
\text { Environmental Monitoring - none } \\
\text { Radioactivity - removed } \\
\text { Surveillance - none } \\
\text { Structures - removal optional } \\
\text { Facility Operating License - terminated }\end{array}$ & $\begin{array}{l}\text { Plant } \\
\text { Site }\end{array}$ & $\begin{array}{l}\text { - Unrestricted } \\
\text { - Unrestricted }\end{array}$ \\
\hline \multicolumn{4}{|l|}{ Safe Storage } \\
\hline Custodial & $\begin{array}{l}\text { Plant Equipment - some operating } \\
\text { Continuing Care Staff - some required } \\
\text { Security - continuous } \\
\text { Environmental Monitoring - continuous } \\
\text { Radioactivity - confined } \\
\text { Surveillance - continuous } \\
\text { Structures - intact } \\
\text { Facility Operating License - amended } \\
\text { version ("possession-only") maintained }\end{array}$ & $\begin{array}{l}\text { Plant } \\
\text { Site }\end{array}$ & $\begin{array}{l}\text { - Restricted } \\
\text { - Restricted }\end{array}$ \\
\hline Passive & $\begin{array}{l}\text { Plant Equipment - none operating } \\
\text { Continuing Care Staff - routine } \\
\text { periodic inspections } \\
\text { Security - remote alarms } \\
\text { Environmental Monitoring - routine } \\
\text { periodic } \\
\text { Radioactivity - immobilized/sometimes } \\
\text { sealed } \\
\text { Surveillance - periodic } \\
\text { Structures - intact } \\
\text { Facility Operating License - amended } \\
\text { version ("possession-only") maintained }\end{array}$ & $\begin{array}{l}\text { Plant } \\
\text { Site }\end{array}$ & $\begin{array}{l}\text { - Restricted, } \\
\text { - Restricted, } \\
\quad \text { some unrestricted (a) }\end{array}$ \\
\hline Hardened & $\begin{array}{l}\text { Plant Equipment - none operating } \\
\text { Continuing Care Staff - none on site } \\
\text { Security - temporary hardened barriers; } \\
\text { fencing and posting; remote alarms } \\
\text { Environmental Monitoring - infrequent } \\
\text { Radioactivity - sealed in hardened } \\
\text { structures } \\
\text { Surveillance - infrequent } \\
\text { Structures - partial removal optional } \\
\text { Facility Operating License - amended } \\
\text { version ("possession-only") maintained }\end{array}$ & $\begin{array}{l}\text { Plant } \\
\text { Site }\end{array}$ & $\begin{array}{l}\text { - Restricted, } \\
\text { some unrestricted (a) } \\
\text { - Restricted, } \\
\text { some unrestricted (a) }\end{array}$ \\
\hline Entombment & $\begin{array}{l}\text { Plant Equipment - none operating } \\
\text { Continuing Care Staff - none on site } \\
\text { Security - hardened barrier; fencing } \\
\text { and posting } \\
\text { Environmental Monitoring - infrequent } \\
\text { Radioactivity - sealed in monolithic } \\
\text { structure } \\
\text { Surveillance - infrequent } \\
\text { Structures - partial removal optional } \\
\text { Facility Operating License - amended } \\
\text { version ("possession-only") maintained }\end{array}$ & $\begin{array}{l}\text { Plant } \\
\text { Site }\end{array}$ & $\begin{array}{l}\text { - Restricted, } \\
\text { some unrestricted (a) } \\
\text { - Restricted, } \\
\text { some unrestricted (a) }\end{array}$ \\
\hline
\end{tabular}

(a) Implies a release of part of the site or the facility for unrestricted use, while maintaining control of the licensed portion that contains radioactive materials above releasable levels. 
of all equipment, structures, and site materials that are radioactively activated or contaminated to levels greater than acceptable residual contamination levels.

Dismantlement can occur immediately following final reactor shutdown, or it can be deferred to a later date in order to allow some decay of radioactivity. The latter alternative requires a period of continuing care prior to dismantlement.

Immediate dismantlement meets the requirements for termination of the facility operating license and renders the BWR facility and site available for unrestricted use within a finite period of time following final reactor shutdown. In this decommissioning mode, large commitments of money (in a relatively short time frame), personnel radiation exposure, and disposal site space are made in exchange for prompt availability of the facility and site for other purposes. Additional considerations include the elimination of continuing security, maintenance, and surveillance requirements (i.e., continuing care for safe storage or entombment), and the availability of the facility operations staff to form a decommissioning work force that is highly knowledgeable about the facility.

Deferred dismantlement includes whatever actions are required at the end of a period of continuing care to terminate the licensee's possession-only license and to release the property for unrestricted use. Some disassembiy and disposal of activated components are still required, but the personnel radiation exposure and the disposal-site space requirements are potentially greatly diminished. Deferred dismantlement cannot, however, rely on the facility operations staff for personnel familiar with the facility. Deferred dismantlement corresponds to "Stage 3 Decommissioning" in International Atomic Energy Agency 1 iterature. (2)

\subsubsection{Safe Storage}

Safe storage comprises those activities required to prepare and maintain the reference BWR property in a condition that places the risk to the public within acceptable bounds and safely stores the property for as long as desired to allow decay of some of the onsite radioactivity. Safe storage 
consists of a period of facility and site preparation, followed by a period of continuing care that encompasses security, surveillance, and maintenance. Since materials having radioactivity levels above unrestricted release levels are still onsite, the possession-only license remains in force throughout the safe storage period.

Three categories of safe storage are possible:

- Custodial safe storage - minimum cleanup and decontamination is made and preventive maintenance on life support and protection systems is performed to prepare the facility. The continuing care period requires full-time, onsite, surveillance crews to maintain the structure and operating equipment and the security of the property. Custodial safe storage is similar to "Stage 1 Decommissioning" in Reference 2 and to the "layaway" mode defined in a previous NRC decommissioning study. (3)

- Passive safe storage - comprehensive cleanup and decontamination sufficient to allow shutdown of all plant systems and installation of strong security barriers and remotely monitored electronic surveillance systems constitute the facility preparations. The continuing care requirements include maintenance of structural integrity and prevention of intrusion into the facility. Passive safe sturage is called "mothballing" in Reference 1 and "protective storage" in Reference 3 .

- Hardened safe storage - facility preparations include the comprehensive cleanup and decontamination of the facility in order to shut down all plant systems, the construction of temporary hardened barriers around areas containing significant quantities of residual radioactivity, and the installation of remotely monitored electronic surveillance systems. The requirements during the continuing care period include maintenance of the barriers and prevention of activities designed to penetrate the barriers. Hardened safe storage is comparable to "Stage 2 Decommissioning" in Reference 2.

Al1 categories of safe storage are open-ended, and some positive action is required at the conclusion of the period of continuing care to release the property for unrestricted use and terminate the possession-only license. 
Depending on the facility. and its operating history, the necessary action can range from a radiation survey (to show that radioactivity has decayed to acceptable levels) to dismantiement and removal of residual radioactive materials. These latter actions, whatever their scale, constitute deferred dismantlement.

Safe storage satisfies the requirements for protection of the public while minimizing, in various degrees, the initial commitments of time, money, occupational radiation exposure, and waste disposal space. This advantage is offset somewhat by the need to maintain the possession-only license and by the associated restrictions placed on the use of the property. This approach requires continuing physical security and surveillance of structural integrity sufficient to ensure public protection.

The commitments that determine the kind of preparation and the kind and length of the continuing care period vary at the choice of the facility owner (with approval of the NRC), and involve considerations of radiation dose and economic trade-offs. The decision to chemically decontaminate the contaminated piping systems during the preparatory period depends largely on the cost and anticipated length of the continuing care period. Since the principal cause of high radiation dose rates in a BWR during and shortly after reactor operation is ${ }^{60} \mathrm{Co}$, a chemical decontamination that achieves a final radioactivity level of one-tenth the original level (decontamination factor of 10) is equivalent to a continuing care (decay) period of approximately 17.5 years. Similarly, a 50-year period of continuing care makes possible a large reduction in personnel exposure and a significant decrease in the need for remote or shielded operations while making the property available for unrestricted use. In addition, much of the radioactive contamination in the facility will decay to releasable levels during a lengthy ( $\geq 110$-year) continuing care period, thus greatly reducing the volume of material requiring disposal and permitting recycle of valuable materials back into commercial channels.

To terminate the possession-only license, even after a continuing care period of more than 100 years, all originally contaminated systems may require dismantling to demonstrate their releasability. In addition, it is anticipated 
that the reactor vessel internals will have to be removed, packaged and transported to a regulated disposal site because of ${ }^{59} \mathrm{Ni}$ and ${ }^{94} \mathrm{Nb}$.

\subsubsection{Entombment}

Entombment is the encasement of nonreleasable radioactive materials in a monolithic structure of concrete or other structural material. The structure should be sufficiently strong and long-lived to ensure retention of the radioactivity until it has decayed to levels that permit unrestricted release of the site. Depending on the approach taken, the entombment period can range from about 100 years to many thousands of years.

Entombment is similar in nature to safe storage in that it also consists of a period of facility and site preparation, followed by a period of continuing care that includes security, surveillance, and maintenance activities. Entombment also requires a possession-only license to remain in force. The facility and site preparations include comprehensive cleanup and decontamination outside of and confinement of nonreleasable materials within the monolithic structure. Continuing care activities are minimal.

Two approaches to entombment are possible: 1) the reactor vessel internals, which have extremely long-lived radioactivity, are removed and shipped to a nuclear waste depository, and 2) the reactor vessel internals are left in place. In each case, as much of the radioactive equipment outside Primary Containment as possible is consolidated and entombed within. In the first case, because of the relatively short half-lives of the entombed radioactivity, it may be possible, without dismantling the structure, to terminate the possession-only license and release the entombment structure for unrestricted use after a continuing care period of about 110 years. (However, present regulations and regulatory guidance do not allow such action without a comprehensive survey to establish that radioactive contamination is within acceptable release limits.) In the second case, existing regulations require the possession-only license to remain in force for an indefinite period of continuing care, unless the reactor vessel internals are removed.

When it becomes desirable to terminate the possession-only license for the entombment mode of decommissioning, dismantling of the entombment structure may be required in the first entombment approach and is required in the 
second approach. This represents a task that is extremely more difficult than dismantling the unentombed facility, since the entombment structure is built to endure for a long period of time. Therefore, the second approach to entombment, and perhaps the first approach also, must be viewed as an almost irreversable commitment to long-term maintenance of the possession-only license. However, dismantlement of the entombment structure is not impossible, only very difficult.

\subsection{CONSIDERATIONS FOR DECOMMISSIONING}

Many considerations must be taken into account in choosing the appropriate decommissioning mode for the specific situation. While not purporting to be a complete or prioritized discussion of all these considerations, this section deals with many of them in qualitative terms according to the following broad categories: economic, licensing, societal, safety, and schedule. It must be recognized that these categories are highly interrelated, but the interrelationships are only alluded to in this section.

\subsubsection{Economic}

While safety during decommissioning is the principal concern of the NRC, economic matters are probably the foremost consideration to stockholders (if a private utility), customers, utility managements, and utility rate commissions.

The following factors that control the economy of decommissioning are discussed:

- property utilization potential

- staffing

- radioactive material disposition

- waste disposal capabilities

- planning and preparation requirements

- taxation

- license and insurance fees

- funding availability.

\subsubsection{Property Utilization Potential}

The potential use of the deactivated plant is a principal economic concern. The site is certified for industrial purposes, and the structures 
and systems are licensed for nuclear power production. As such, they represent a significant investment in time and money. Although retrofitting of some auxiliary systems may be necessary to meet the extant 1 icensing requirements, refurbishing of the primary systems to meet code requirements could facilitate the reactivation of the facility for power production.

However, if reactivation is not desirable or is not possible, use of the property for other purposes should be studied. The results could dictate the mode of decommissioning.

\subsubsection{Staffing}

A sufficient number of properly trained and skilled personnel is a significant cost factor in decommissioning. For decommissioning activities that commence immediately following final reactor shutdown, it is desirable to draw the personnel from the ranks of the plant operating staff. These personnel are very familiar with the structures, systems, radiation work procedures, and specific areas of radiation exposure potential. Specifically, supervisory personnel, health physics personnel, maintenance craft personnel, and personnel trained in conventional decontamination methods and in the operation of the systems required during decommissioning (refer to Table 9.1-2) should be recruited prior to plant shutdown. The supervisory personnel (see Section 9.1.5) are largely responsible for formulating the plans and making the preparations for decommissioning, and, therefore, should be available to begin these duties approximately 2 years before plant shutdown. The other personnel should be available as necessary to augment the planning and preparation effort, to become trained in the operation of any special decommissioning equipment, and, then, to implement the plans.

Some of the operating plant staff may not wish to be involved in the decommissioning effort. It is then necessary to fill vacant positions from elsewhere within the company or from outside labor pools. Hopefully, the local job market can supply any required outside people; but this may not be the case and importation then becomes necessary. These kinds of personnel may require training in radiation work procedures as well as in special equipment operation, which becomes an added expense. 
For decommissioning activities that are performed after a significant length of time following shutdown, personnel must be selected from elsewhere within the company or from the outside labor pool. Again, training becomes a cost factor. Alternatively, the job could be contracted with a firm that specializes in decommissioning work.

\subsubsection{Radioactive Material Disposition}

Several factors pertaining to radioactive material disposition help determine the cost of decommissioning. These are the amounts and kinds of radioactive materials on the property when decommissioning activities are to proceed, and the existing regulatory requirements concerning personnel radiation exposure, unrestricted release levels, and radioactive material handling and disposal. These factors directly affect the following aspects: decontamination and decommissioning procedures, packaging and transportation procedures, and time requirements for implementation. These aspects, in turn, help determine the kind, number, utilization, and efficiency of staff personnel.

\subsubsection{Waste Disposal Capabilities}

A current major concern of nuclear facility owners is the availability of nuclear waste disposal sites. (4) The mode of decommissioning is largely determined by the existence of an available nuclear waste disposal site of sufficient size to handle the associated wastes. The disposal requirements for the highly radioactive and long-lived components in and around the reactor vessel are, as yet, not clearly defined as to whether shallow-land burial is acceptable or deep geologic storage is required.

Another area of concern in this respect is the location and accessability of an operable nuclear disposal site. The cost of shipping the decommissioning wastes to the disposal site is determined in part by the distance traveled and in part by the requirements that are imposed by the states through which the radioactive materials must travel.

Although federal agencies dominate the regulatory process in the shipment of radioactive materials, state highway departments regulate gross vehicle weights and dimensions, as well as some other aspects of radioactive shipments. Currently, about half of the states have adopted the DOT Hazardous Materials Regulations to cover intrastate radioactive material shipments. In addition, 
several states have adopted or proposed additional regulations for other aspects of radioactive material shipments. $(5,6)$ These aspects include:

- special routing

- advance notification for shipments of large quantities

- state inspections of some types

- prohibition of certain types

- prior approval

- requirements of exclusive-use vehicles

- use of pilot vehicles

- speed restrictions

- specific hours of movement

- accompaniment of all shipments by radiation monitoring personnel.

The variation of regulations between adjacent states often requires special considerations for interstate shipments.

There is a potential conflict between some of the proposed state laws and the provisions of the National Transportation Act of 1974 (Public Law 93-633, signed in 1975). This law prohibits the states from adopting laws or regulations more stringent than federal regulations unless state regulations improve transportation safety. Even in this case, such rules can be adopted only if they do not unreasonably burden commerce.

\subsubsection{Planning and Preparation Requirements}

The cost of preparing the detailed decommissioning plans, technical specifications, safety analyses, and documentation may be different for each of the decommissioning modes and should be considered. For example, a comprehensive dismantlement plan is required for dismantlement and entombment, but for safe storage preparations, a less comprehensive initial plan is acceptable. For eventual dismantlement, a complete dismantlement plan would be required at that time.

\subsubsection{Taxation}

A tactor that could have considerable influence on the choice of mode and time frame for decommissioning is the way that the facility is viewed by the local taxing authorities for property tax purposes. For example, it is 
possible that the plant in safe storage or entombment could be taxed at one of the following values: 1) an operating plant, 2) unimproved land, or 3) the land and structures minus the expected additional decommissioning costs (since the retired plant is a negative asset). The first alternative (which is unlikely) would force immediate dismantlement of the plant, since the accumulated tax costs would, in a few years, exceed the cost of dismantlement. The third approach would reduce the taxes to a very nominal amount, since the additional decommissioning costs could exceed the value of the land and structures. In practice, the tax rate will be negotiated between the local tax assessor and the plant owner. It will likely be based on a combination of the second and third situations given above, with the land outside the exclusion area assessed at a value comparable with adjacent similar property and the property within the exclusion area assessed at essentially zero value. Since the outer area of the site may be unrestricted in use once the reactor has been decommissioned, it may be put to productive use to pay its property taxes.

\subsubsection{License and Insurance Fees}

Other economic factors that could have a role in determining the decommissioning mode are the costs of licensing and the costs of nuclear liability insurance. Both, as presently applied, require a significant initial outlay and then diminish as the amount of residual radioactivity is reduced.

Licensing fees are required for amending the facility operating license to a possession-only license, which allows possession but not operation of the facility. Thereafter, inspection fees are levied based on the NRC inspection requirements. Presently, while any spent fuel remains on the site, safeguards inspections must continue as during operation. In addition, annual health, safety and environmental inspections must continue until the possessiononly license is terminated.

The cost of nuclear liability insurance depends on the level of coverage required by NRC as proof of financial protection during decommissioning. If the level must remain the same regardless of the plant condition (which is unlikely), timely termination of the possession-only license is mandatory. 


\subsubsection{Funding Availability}

As with all projects, there are certain fixed costs during decommissioning that continue once the project begins, regardless of the activity towards project completion (i.e., salaries, services, utilities, and maintenance). If insufficient funding delays decommissioning activities, these fixed costs, plus the effect of inflation over the delay period, increase the overall decommissioning cost. Therefore, it is important that sufficient funds are available to complete the planned decommissioning activities as scheduled.

\subsubsection{Licensing}

Licensing in the nuclear industry is basically a question of responsibility for the protection of the workers and the public from undue exposure to regulated radioactive materials. In this respect, an organization is licensable only as it can demonstrate a continued ability and willingness to abide by the license requirements imposed by the NRC. Once the license is granted, the licensee agrees to accept the associated responsibilities until such time as the license is terminated (or transferred to another licensed organization, as allowed by law).

Termination of a possession-only ticense (amended operating license) is conditional on the dismantlement and proper disposal of nonreleasable radioactive materials. While the high occupational exposure from immediate dismantlement is undesirable, the requirements and responsibilities of maintaining the license may overshadow the exposure aspect and make dismantlement expedient. The dynamic nature of government regulation may also make termination of the license desirable.

Another aspect of licensing that must be considered is the license duration and the license renewal process and cost. Licenses are presently subject to a 40-year time limit, at which time they must be renewed. The renewal review requirements comprise financial, safety, and environmental considerations similar to those for a license amendment situation. The costs of documenting these considerations and the NRC review costs for each required license renewal must be taken into account when choosing the appropriate decommissioning mode. 


\subsubsection{Societal}

Another consideration is that of public acceptance of the long-term presence of retired facilities. There is a reasonable probability that once the plant is no longer providing tax revenue and payroll to the community, the public may view the structures as an eyesore, a perceived hazard, or, at the least, an unproductive use of an otherwise useful site. Thus, pressures may mount for the removal of the retired structures. While it is beyond the scope of this study to evaluate the likelihood of this concern, the plant owner should sample local public opinion on this question well in advance of setting his plans for decommissioning.

In the same vein, the NRC presently desires to minimize the number of sites permanently committed to the containment of radioactive materials. Dismantlement and disposal of the reactor vessel internals is the only method whereby this desire can be fulfilled for the reference BWR, even in the long run. Existing règulations allow the various modes of decommissioning that are detailed in Section 4.1. But regulations are dynamic in nature and are subject to societal pressures; and, even though new regulations or changes to present regulations may never forbid the use of a particular decommissioning mode, they could discourage or make impractical the use thereof.

\subsubsection{Safety}

Radiological, industrial, and environmental safety play an important role in decommissioning. Each is regulated by the federal government or the state government, or both, to provide the amount of protection from hazards that is deemed necessary. The selected decommissioning approach should provide the required safety for the workers and the public, and should have minimal adverse impact on the environment.

\subsubsection{Radiological Safety}

In decommissioning a $\mathrm{BWR},{ }^{60} \mathrm{Co}$ is the prime contributor to the total accumulated occupational radiation dose. It appears as activated corrosion product contamination in and on equipment and structural surfaces and as an activation product in structural materials in and around the reactor vessel. Each decommissioning mode results in a different accumulated occupational dose because of different exposure requirements. 
Dose rates throughout the plant, largeiy determined by the amount and decay of ${ }^{60} \mathrm{Co}$, decay to approximately $10 \%$ of the original shutdown values after about 17.5 years in shutdown and $1 \%$ after about 35 years, assuming no decontamination. Therefore, deferring the major decommissioning activity by even 17.5 years produces a significant potential decrease in accumulated occupational dose. This depends, of course, on the required decommissioning activities prior to that point in time and those necessary to complete the license-termination process. Relatively little reduction in total accumulated occupational radiation dose is assumed to result from deferring dismantlement beyond 30 years after placing a pressurized water reactor in passive safe storage. (7) This is also assumed to be the case for a BWR.

\subsubsection{Industrial Safety}

Hazardous situations with the potential for occupational injuries and fatalities will arise during normal activities of each decommissioning mode. The quantity and severity of occurrences associated with a given decommissioning mode depend on the kinds of activities performed and the manpower and time requirements for that mode. As with every industrial operation, proper industrial safety practices during decommissioning will minimize accidents.

\subsubsection{Environmental Safety}

Many of the environmental effects of plant operation will also be evident during decommissioning, but in most cases at greatly diminished levels. The environmental effects that pertain to decommissioning are radiation exposure (already discussed), liquid and airborne radioactive release, and solid radwaste disposal. No thermal discharge is required during decommissioning except, perhaps, that associated with operation of an auxiliary boiler.

At final shutdown of the reference BWR, large volumes of water requiring disposal during any decommissioning mode are scattered throughout the plant. Some of these volumes are in presumably noncontaminated systems and, after sampling, can be released directly to the river via the blowdown line. 0thers, notably those contained in the spent fuel pool, the reactor vessel, the suppression chamber, the condensate storage tanks, and the condenser hotwell, are contaminated in varying degrees and may require processing through the liquid 
radwaste systern prior to discharge. Altogether, these volumes of water represent a large discharge to the environment, but are only about $0.3 \%$ of the normal annual operating plant discharge.

Airborne radioactive releases that result from normal decommissioning activities are small in comparison to normal plant operation. (7) Among the various decommissioning modes, safe storage releases the least amount of airborne radioactivity.

Dismantlement generates large amounts of solid radioactive wastes that require disposal off site. Entombment produces less although the entombed structure becomes a waste disposal site, and safe storage including deferred dismantlement, the least. The major environmental impact of solid radioactive waste disposal is the land area that must be committed to this activity. In addition, shipping these wastes to the disposal site produces the normal transportation noises, exhaust fumes, etc. Therefore, the more wastes, the greater impact.

\subsubsection{Schedule}

A large percentage of the facility decommissioning cost is a fixed level of expenditure that is associated with the time span of the work rather than the specific tasks. Therefore, the optimum schedule for any decommissioning mode is one where the total time involved is the time required to efficiently complete the longest sequence of tasks. This dictates the necessary length of time (the critical path) to complete the entire job, and all other work should be completed within this time span. An optimum-sized, well-trained staff is essential: too many or too few people, as well as undertrained people, hamper the efficient completion of the work, thus increasing both the total cost and the total accumulated occupational radiation exposure. As previously discussed, insufficient funding to complete the work within the critical-path time span also drives these totals upward.

\subsection{EXPERIENCE IN DECOMMISSIONING}

This section contains a review of the experience in decommissioning of nuclear facilities. Because of the many differences in the decommissioned acilities, extrapolation of the costs for decommissioning these facilities 
to large commercial reactors is considered to be generally unreliable. Many of the reactors that have been decommissioned were involved in the U.S. AEC power demonstration program and were operated only for short periods of time. The primary value of past decommissioning experience is in identification of the methods and technologies of decommissioning.

The decommissioning of nuclear facilities is a relatively well-developed technology. In the United States, the term "decommissioning" conventionally means to retire safely from active service. Historically, decommissioning of most nuclear facilities did not result in terminal conditions. In fact, the safe storage and entombment approaches that have been used are recognized as nonterminal. Current NRC decommissioning philosophy promotes a decommissioning approach that ends in the termination of the facility's nuclear license and the release of the property for unrestricted use within a finite period of time.

Past decommissionings of nuclear facilities have been accomplished by dismantlement, safe storage, entombment, or a combination of these alternatives. To date, alternative selection has been based primarily on cost. In addition, the selected approach to decommissioning provided for protection of the workers and the public and for minimal adverse impacts on the environment.

\subsubsection{Nuclear Reactor Decommissioning Experience}

Nuclear reactors for power demonstration, military, and research applications have been safely decommissioned using a variety of decommissioning approaches, and without undue risk to personnel or to the environment. It is the conclusion of this report that similar methods can be safely and successfully applied to a large commercial BWR power plant.

Between 1960 and mid-1976, a total of 65 nuclear reactors were or were scheduled to be decommissioned. (8) of these, five were nuclear power plants, four were demonstration nuclear power plants, six were 1 icensed test reactors, 28 were research reactors, and 22 were critical facilities. Of the 50 licensed research reactors and critical facilities decommissioned or scheduled to be decommissioned by mid-1976, all but four had been or will be totally dismantled, with their licenses terminated. The remaining four will retain a possessiononly license for an indefinite period in safe storage. 
Information on past nuclear reactor decommissionings is presented in Table 4.3-1. Descriptions of some of the more significant reactor decommissionings follow. Most of these descriptions are from Reference 9.

\subsubsection{Carolina-Virginia Tube Reactor (CVTR),} Parr, South Carolina

The CVTR was a 65-MWt, heavy-water cooled and moderated, pressure tube reactor. The decision to decommission the plant was made in 1967 after 4 years of experimental operation. The plan adopted was to deactivate the reactor by the passive safe storage mode, surrender the AEC operating license, and use the Containment Building and Reactor Building for long term storage of remaining radioactive materials under a byproduct $1 i$.cense issued by the state of South Carolina.

A11 fuel and heavy water were shipped offsite. The facility license was changed from operation status to possession-only status, and an authorization was obtainèd from the AEC to decommission the facility. The facility license was replaced by the byproduct license on completion of both the active decommissioning and an AEC inspection. Remaining radioactive materials were stored, where possible, in their normal operating position. The control rod drive system was deactivated. Voids containing radioactive materials were sealed, and access hatches to the Containment Building were bolted shut so that special equipment was required to open them. A double security barrier was placed around all areas containing radioactive material.

The decision to decommission the reactor with minimum dismantling and removal of radioactive materials meant substantial cost-savings and minimum radiation exposure to plant personnel during the operation.

Decommissioning of the CVTR is further described in Reference 10.

4.3.1.2 Hallam Nuclear Power Facility, Hallam, Nebraska

The Hallam Facility was located at the Sheldon Station of the Consumers' Public Power District. It first became operational in 1963. The sodiumcooled, graphite-moderated reactor produced $256 \mathrm{MWt}$. It was retired from service in 1966, and the reactor entombment was completed in 1969. 


\section{TABLE 4.3-1. Information on Past Nuclear Reactor Decommissionings}

\begin{tabular}{|c|c|c|c|c|c|c|c|c|}
\hline Facylity Same and Location & Reactor Type & $\begin{array}{r}\text { Power } \\
\text { Rating(a) }\end{array}$ & $\begin{array}{c}\text { Type of } \\
\text { Decommiss ioning }\end{array}$ & License Status & $\begin{array}{c}\text { Monitoring } \\
\text { System }\end{array}$ & $\begin{array}{l}\text { Safe Storage } \\
\text { Measures }\end{array}$ & $\begin{array}{c}\text { Year } \\
\text { Decommiss ioned }\end{array}$ & $\begin{array}{c}\text { Other } \\
\text { Information }\end{array}$ \\
\hline $\begin{array}{l}\text { HRE-1 (Homogeneous Reactor } \\
\text { Experiment), Oak Ridge, TN }\end{array}$ & Fluid-fuel & $1 \mathrm{MWt}$ & Dismantled & $-(b)$ & - & - & 1954 & - \\
\hline $\begin{array}{l}\text { HRE-2 (Homogeneous Reactor } \\
\text { Experiment), Oak Ridge, TN }\end{array}$ & Flund-fuel & $<1$ MWt & Dismantled & - & - & - & 1954 & - \\
\hline $\begin{array}{l}\text { ARE (Aircraft Reactor Experi- } \\
\text { ment), Oak Ridge, IN }\end{array}$ & Fluid-fuel & $1 \mathrm{MWt}$ & Dismantled & - & - & - & 1955 & - \\
\hline $\begin{array}{l}\text { PM-2A (Portable Medium Power } \\
\text { Plant), Greenland }\end{array}$ & PWR & 10 Mwt & Dismantled & - & - & - & 1964 & - \\
\hline $\begin{array}{l}\text { Hanford Production Reactors, } \\
\text { Richland, WA }\end{array}$ & $\begin{array}{l}\text { Graphite } \\
\text { moderated, water } \\
\text { cooled }\end{array}$ & - & $\begin{array}{l}\text { Custodial Safe } \\
\text { Storage (Lay- } \\
\text { away), 4-Stand- } \\
\text { by, 4-Retired }\end{array}$ & - & $\begin{array}{l}\text { Continuous } \\
\text { survelllance } \\
\text { by DOE }\end{array}$ & $\begin{array}{l}\text { Continuous } \\
\text { maintenance by } \\
\text { DOE }\end{array}$ & $1965-1971$ & $\begin{array}{l}\text { One planned for } \\
\text { dismantling }\end{array}$ \\
\hline $\begin{array}{l}\text { CVIR (Carolina Virginia Tube } \\
\text { Reactor). Parr, SC }\end{array}$ & $\begin{array}{l}\text { Pressure tube, } \\
\text { heavy water } \\
\text { cooled and } \\
\text { moderated }\end{array}$ & 65 Mwt & $\begin{array}{l}\text { Passive Safe } \\
\text { Storage } \\
\text { (mothballed) }\end{array}$ & $\begin{array}{l}\text { Byproduct } \\
\text { State(c) }\end{array}$ & $\begin{array}{l}\text { Periodic } \\
\text { survelllance }\end{array}$ & $\begin{array}{l}\text { welded closure, } \\
\text { locked doors, } \\
\text { security fence }\end{array}$ & $1968^{(d)}$ & - \\
\hline $\begin{array}{l}\text { Hallam Nuclear Power } \\
\text { Facility, Hallam NB }\end{array}$ & $\begin{array}{l}\text { Graphite modera- } \\
\text { ted, sodium } \\
\text { cooled }\end{array}$ & $256 \mathrm{MWt}$ & Entombed & $\begin{array}{l}\text { Operating } \\
\text { authorization } \\
\text { terminated }\end{array}$ & $\begin{array}{l}\text { Periodic } \\
\text { survelllance } \\
\text { by DOE }\end{array}$ & $\begin{array}{l}\text { Welded closure, } \\
\text { concrete cover, } \\
\text { weatherproofed }\end{array}$ & 1969 & $\begin{array}{l}\text { Decommissioning } \\
\text { took } 3 \text { years }\end{array}$ \\
\hline $\begin{array}{l}\text { Piqua Nuclear Power } \\
\text { Facility, Piqua, OH }\end{array}$ & $\begin{array}{l}\text { Organic cooled } \\
\text { and moderated }\end{array}$ & 45 Mwt & Entombed & $\begin{array}{l}\text { Operating } \\
\text { authorization } \\
\text { terminated }\end{array}$ & $\begin{array}{l}\text { Periodic } \\
\text { surve } 117 \text { ance } \\
\text { by DOE }\end{array}$ & $\begin{array}{l}\text { Welded closure, } \\
\text { concrete cover, } \\
\text { waterproofed }\end{array}$ & 1969 & $\begin{array}{l}\text { Decommissioning } \\
\text { took } 3 \text { Years }\end{array}$ \\
\hline $\begin{array}{l}\text { BONUS (Boiling Nuclear } \\
\text { Superheater Power Sta- } \\
\text { tion, Ricon, PR }\end{array}$ & $\begin{array}{l}\text { BWR with nuclear } \\
\text { superheating }\end{array}$ & $50 \mathrm{MWt}$ & Entombed & $\begin{array}{l}\text { Operating } \\
\text { duthorization } \\
\text { terminated }\end{array}$ & $\begin{array}{l}\text { Periodic } \\
\text { survelllance } \\
\text { by DOE }\end{array}$ & $\begin{array}{l}\text { Welded closure, } \\
\text { concrete cover, } \\
\text { security fence }\end{array}$ & 1970 & - \\
\hline $\begin{array}{l}\text { Waiter Reed Research Reactor, } \\
\text { Washington, DC }\end{array}$ & $\begin{array}{l}\text { AI Model L-54, } \\
\text { homogeneous fue } 1\end{array}$ & $50 \mathrm{kWt}$ & Dismantled & - & - & - & 1971 & - \\
\hline Pathfinder, Sioux Falls, SD & $\begin{array}{l}\text { BWR with nuclear } \\
\text { superheating }\end{array}$ & $190 \mathrm{MWt}$ & $\begin{array}{l}\text { Passive Safe } \\
\text { Storage (moth- } \\
\text { balled) with } \\
\text { steam plant } \\
\text { conversion }\end{array}$ & $\begin{array}{l}\text { Byproduct } \\
\text { NRC }(c)\end{array}$ & $\begin{array}{l}\text { Cont inuous } \\
\text { securlty } \\
\text { forcele }\end{array}$ & $\begin{array}{l}\text { Welded closure, } \\
\text { security fence }\end{array}$ & 1972 & $\begin{array}{l}\text { Decommissioning } \\
\text { cost } \$ 37 M\end{array}$ \\
\hline B\&W, Lynchburg, VA & Pool & $6 \mathrm{MWt}$ & $\begin{array}{l}\text { Partially } \\
\text { Dismantled }\end{array}$ & $\begin{array}{l}\text { Byproduct } \\
\text { NRC }\end{array}$ & $\begin{array}{l}\text { Continuous } \\
\text { security } \\
\text { force }\end{array}$ & $\begin{array}{l}\text { Locked doors, } \\
\text { security fence }\end{array}$ & 1972 & - \\
\hline $\begin{array}{l}\text { EBR-1 (Experimental Fast } \\
\text { Breeder Reactor). } \\
\text { Scottsville, } 10\end{array}$ & $\begin{array}{l}\text { Liquid metal } \\
\text { cooled }\end{array}$ & - & $\begin{array}{l}\text { Deactivated, } \\
\text { decontaminated, } \\
\text { converted for } \\
\text { public access }\end{array}$ & - & - & - & 1973 & $\begin{array}{l}\text { Dedicated a } \\
\text { National Monu- } \\
\text { ment in } 1966\end{array}$ \\
\hline $\begin{array}{l}\text { Saxton Nuclear Experimental } \\
\text { Facility, Saxton, PA }\end{array}$ & PWR & 23 MWt & $\begin{array}{l}\text { Passive Safe } \\
\text { Storage } \\
\text { (mothballed) }\end{array}$ & $\begin{array}{l}\text { Possession } \\
\text { only } f(f)\end{array}$ & $\begin{array}{l}\text { Intrusion } \\
\text { alarms }\end{array}$ & $\begin{array}{l}\text { Welded closure, } \\
\text { locked doors, } \\
\text { security fence }\end{array}$ & $197 j$ & $\begin{array}{l}\text { Decommissioning } \\
\text { cost } \$ 25 M\end{array}$ \\
\hline $\begin{array}{l}\text { SEFOR (Southwest Experimental } \\
\text { Fast Oxide Reactor). } \\
\text { Strickler, AR }\end{array}$ & $\begin{array}{l}\text { Sodium: cooled, } \\
\text { fast }\end{array}$ & 20 Mwt & $\begin{array}{l}\text { Passive Safe } \\
\text { Storage } \\
\text { (mothballed) }\end{array}$ & $\begin{array}{l}\text { Byproduct } \\
\text { State }\end{array}$ & $\begin{array}{l}\text { Intrusion } \\
\text { alarms }\end{array}$ & $\begin{array}{l}\text { Welded closure, } \\
\text { locked doors, } \\
\text { security fence }\end{array}$ & 1973 & - \\
\hline $\begin{array}{l}\text { Elk River Reactor, } \\
\text { Elk River, MN }\end{array}$ & $\begin{array}{l}\text { BWR with foss } 11 \\
\text { superheating }\end{array}$ & 58 Mwt & $\begin{array}{l}\text { Dismantled with } \\
\text { steam plant } \\
\text { conversion }\end{array}$ & Termınated $(g)$ & $\begin{array}{l}\text { Not } \\
\text { required }\end{array}$ & Not required & 1974 & $\begin{array}{l}\text { Decommissioning } \\
\text { cost } \$ 615 \mathrm{M}, \\
\text { took } 3 \text { years }\end{array}$ \\
\hline \multicolumn{9}{|c|}{ 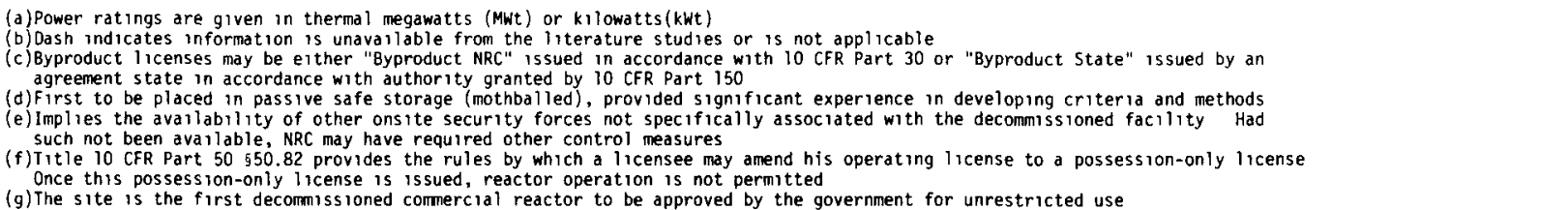 } \\
\hline
\end{tabular}


TABLE 4.3-1. (cont'd)

\begin{tabular}{|c|c|c|c|c|c|c|c|c|c|}
\hline Facility Name and Location & Reactor Type & $\begin{array}{r}\text { Pol } \\
\text { Rat }\end{array}$ & wer & $\begin{array}{c}\text { Type of } \\
\text { Decommissioning }\end{array}$ & License Status & $\begin{array}{c}\text { Moni toring } \\
\text { System }\end{array}$ & $\begin{array}{l}\text { Safe Storage } \\
\text { Measures }\end{array}$ & $\begin{array}{c}\text { Year } \\
\text { Decommissioned }\end{array}$ & $\begin{array}{c}\text { Other } \\
\text { Information }\end{array}$ \\
\hline $\begin{array}{l}\text { ASTR (Aerospace Test } \\
\text { Reactor), U S Air Force, } \\
\text { NARF, Ft. Worth, Tx }\end{array}$ & - & 10 & Mut & Dismantled & - & - & * & 1974 & - \\
\hline $\begin{array}{l}\text { GTR (Ground Test Reactor), } \\
\text { U S Air Force, NARF, } \\
\mathrm{Ft} \text { Worth, TX }\end{array}$ & - & & wht & Dismantled & - & - & - & 1974 & - \\
\hline $\begin{array}{l}\text { RTA (Reactivity Test } \\
\text { Assembly), U.S Air force, } \\
\text { NARF, Ft worth, TX }\end{array}$ & - & & Mwt & Dismantled & - & - & - & 1974 & - \\
\hline FERMI T, Monroe Co MI & $\begin{array}{l}\text { Sodium cooled, } \\
\text { fast }\end{array}$ & 200 & Mwt & $\begin{array}{l}\text { Passive Safe } \\
\text { Storage (moth- } \\
\text { balled) with } \\
\text { steam plant } \\
\text { conversion }\end{array}$ & $\begin{array}{l}\text { Possession } \\
\text { only }\end{array}$ & $\begin{array}{l}\text { Continuous } \\
\text { security } \\
\text { force }\end{array}$ & $\begin{array}{l}\text { Locked doors, } \\
\text { security fence }\end{array}$ & 1975 & $\begin{array}{l}\text { Decormissioning } \\
\text { cost } \$ 695 \mathrm{M}\end{array}$ \\
\hline $\begin{array}{l}\text { PM-3A (Portable Medlum Power } \\
\text { Plant), Antarctica }\end{array}$ & PWR & & MNt & Dismantled & - & - & - & 1977 & - \\
\hline $\begin{array}{l}\text { HTR (Hanford Test Reactor), } \\
\text { Richland, WA }\end{array}$ & $\begin{array}{l}\text { Graphite } \\
\text { moderated }\end{array}$ & $\begin{array}{l}\text { Zero } \\
\text { Powe }\end{array}$ & & Dismantled & - & - & - & 1977 & $\begin{array}{l}\text { Decommissioning } \\
\text { cost \$0 } 18 \mathrm{M}\end{array}$ \\
\hline $\begin{array}{l}\text { IRL (Industrial Reactor } \\
\text { Laboratories Inc Research } \\
\text { Reactor). PIainsboro, NJ }\end{array}$ & Pool & & MWt & $\begin{array}{l}\text { Partialty } \\
\text { dismantied }\end{array}$ & - & - & $\begin{array}{l}\text { Unrestricted } \\
\text { use }\end{array}$ & 1977 & $\begin{array}{l}\text { Decommissioning } \\
\text { cost } \$ 1 M \text {, took } \\
2 \text { years }\end{array}$ \\
\hline GE EVESR, Alameda Co , CA & $\begin{array}{l}\text { BWR with nuclear } \\
\text { superheat ing }\end{array}$ & 17 & Mwt & $\begin{array}{l}\text { Passive Safe } \\
\text { Storage } \\
\text { (mothballed) }\end{array}$ & $\begin{array}{l}\text { Possession } \\
\text { only }\end{array}$ & $\begin{array}{l}\text { Cont inuous } \\
\text { security } \\
\text { force }\end{array}$ & $\begin{array}{l}\text { Locked doors, } \\
\text { security fence }\end{array}$ & - & - \\
\hline NASA Plumbrook, Sandusky, $\mathrm{OH}$ & Light water & 100 & Kwit & $\begin{array}{l}\text { Passive Safe } \\
\text { Storage } \\
\text { (mothballed) }\end{array}$ & $\begin{array}{l}\text { Possession } \\
\text { only }\end{array}$ & $\begin{array}{l}\text { Cont inuous } \\
\text { security } \\
\text { force }\end{array}$ & $\begin{array}{l}\text { Locked doors, } \\
\text { security fence }\end{array}$ & - & - \\
\hline $\begin{array}{l}\text { Peach Bottom 1, } \\
\text { York Co. PA }\end{array}$ & $\begin{array}{l}\text { Gas cooled, } \\
\text { graphite } \\
\text { moderated }\end{array}$ & 115 & Mwt & $\begin{array}{l}\text { Passive Safe } \\
\text { Storage } \\
\text { (mothballed) }\end{array}$ & $\begin{array}{l}\text { Possession } \\
\text { only }\end{array}$ & $\begin{array}{l}\text { Cont inuous } \\
\text { security } \\
\text { force }\end{array}$ & $\begin{array}{l}\text { Not yet estab- } \\
\text { lished }\end{array}$ & & - \\
\hline $\begin{array}{l}\text { VBWR (Vallecitos Bolling } \\
\text { Water Reactor), } \\
\text { Alameda Co, CA }\end{array}$ & BWR & 50 & Mwit & $\begin{array}{l}\text { Passive Safe } \\
\text { Storage (moth- } \\
\text { balled) with } \\
\text { steam plant } \\
\text { conversion }\end{array}$ & $\begin{array}{l}\text { Possession } \\
\text { only }\end{array}$ & $\begin{array}{l}\text { Cont inuous } \\
\text { security } \\
\text { force }\end{array}$ & $\begin{array}{l}\text { Locked doors, } \\
\text { security fence }\end{array}$ & - & - \\
\hline $\begin{array}{l}\text { Westinghouse Test Reactor, } \\
\text { Waltz MIlls, PA }\end{array}$ & Tank & 60 & Mut & $\begin{array}{l}\text { Passive Safe } \\
\text { Storage } \\
\text { (mothballed) }\end{array}$ & $\begin{array}{l}\text { Possessian } \\
\text { only }\end{array}$ & $\begin{array}{l}\text { Cont inuous } \\
\text { security } \\
\text { force }\end{array}$ & $\begin{array}{l}\text { Locked doors, } \\
\text { security fence }\end{array}$ & - & - \\
\hline $\begin{array}{l}\text { SRE (Sodium Reactor } \\
\text { Experiment), } \\
\text { Santa Susand, CA }\end{array}$ & $\begin{array}{l}\text { Graphite } \\
\text { moderated, } \\
\text { sodium }\end{array}$ & 301 & Mwt & $\begin{array}{l}\text { Passive Safe } \\
\text { Storage (moth- } \\
\text { balled - 1967) } \\
\text { dismantling } \\
\text { started } 1976\end{array}$ & - & - & - & $\begin{array}{l}\text { Dismantling } \\
\text { in progress }\end{array}$ & $\begin{array}{l}\text { Decommissioning } \\
\text { costs expected } \\
\text { to be } 2 \$ 10 \mathrm{M}\end{array}$ \\
\hline
\end{tabular}


All fuel and bulk sodium were removed from the site. Residual sodium was rendered inert, and all radioactive residues were removed to a federal repository. Heat exchangers were dismantled and removed. Radioactive components and materials remaining onsite were sealed in underground vaults surrounding the reactor vessel. Two 12.5-mm-thick steel plates were welded over the reactor area, all penetrations to the underground vaults were seal welded, and the entire area was covered with layers of tar, earth, and plastic film.

No special techniques or equipment were developed for this operation. Residual sodium was rendered passive by purging with a gaseous nitrogen-steam mixture. Normal operational procedures were used for the removal of all radioactive materials.

A total of $300,000 \mathrm{Ci}$ of radioactivity, mainly associated with the reactor vessel and internals, was sealed in the reactor and underground vaults. The bulk sodium removed from the primary circuit was slightly radioactive ( $7 \mathrm{Ci}$ in the $250,000-\mathrm{kg}$ shipment). A special sodium-cleaning facility was erected for the decontamination of system components. The site is periodically inspected by State of Nebraska authorities. In addition to being archived, drawings, reports, analyses and photographs relating to the buried structures were encapsulated and placed within the structure in two locations.

Additional details on the retirement of the Hallam facility are reported in References 11,12 , and 13.

\subsubsection{Piqua Nuclear Power Facility, Piqua, Ohio}

The Piqua Facility, an organic cooled, organic moderated, 45-MWt power reactor, was shut down in 1966 and entombed in 1969. The Piqua site was purchased by the federal government and leased to the city of Piqua. The decommissioning activities were undertaken by City of Piqua personnel, with engineering and safety support from Atomics International. Consulting was provided by Battelle Memorial Institute.

A reactor retirement plan, including work specifications and detailed procedures, was prepared. A safety analysis and study evaluation of residual radionuclides were conducted and reported. 
Reactor core components, fuel, and other radioactive materials were shipped to a federal repository using normal procedures. The organic coolant was incinerated. Contaminated piping and equipment inside the Reactor Building were removed or decontaminated, and the above-ground portion of the Reactor Building was converted to a warehouse. The reactor vessel, thermal shield, grid plates, and support barrels remained in place below grade; the vessel was filled with sand and seal welded, and all penetrations into the reactor complex were plugged. The below-ground complex was then sealed with a waterproof barrier and concrete cover. The development of special equipment or techniques was not required.

The total radioactivity sealed in the facility was $260,000 \mathrm{Ci}$. In addition to being archived, detailed records of all operations were duplicated and placed in sealed metal boxes at the site.

Cost estimates or actual cost totals were not available from the literature studied. More detail on the Piqua decommissioning can be found in References 12 and 14.

\subsubsection{Boiling Nuclear Superheater (BONUS) Power Station, Ricon, Puerto Rico}

BONUS was a 50-MWt BWR with nuclear superheat. The reactor ceased operation in 1967, and the operating contract was terminated a year later. The reactor was entombed in 1970. Increasingly stringent AEC design criteria involving expensive retro-fitting, poor economics, low availability, and change in emphasis away from the superheat program led to the decision to decommission. The utility, the Puerto Rico Water Resources Authority, was to convert the decommissioned plant to an exhibition open to the public for a maximum of 5 years. The utility was responsible for implementing decommissioning, preparing documents, and scheduling and carrying out the operations. Control of the program was achieved in accordance with program specifications and detailed procedures. A11 activities except construction of the entombment structure were allowed to be implemented before issuance of the AEC dismantling order.

The work was divided into four phases: 
- Initial radiation survey; sampling of selected plant equipment and piping; shipping of spare unused fuel assemblies; removal of spent fuel from reactor vessel; permanent disabling of control rod drive mechanism.

- Shipping of spent fuel, radioactive sources and wastes; decontamination; preparation for entombment.

- Construction of entombment structure.

- Preparation of documentation for transfer of license; handing facility over for exhibition purposes.

A radiological safety analysis was conducted to assist in the design of the entombment structure. The initial entombed radioactivity total was approximately $50,000 \mathrm{Ci}$. The dose rate at the surface of the entombment structure was not to exceed $0.4 \mathrm{mR} / \mathrm{hr}$ at $1 \mathrm{~cm}$, except for permissible hot spots up to $1 \mathrm{mR} / \mathrm{hr}$ as long as an average surface radiation level of $0.2 \mathrm{mR} / \mathrm{hr}$ was not exceeded.

A hazard assessment was made of the entombed plant for a postulated design-basis accident (severe earthquake followed by tidal wave flood). Even on the basis of the most pessimistic assumptions it was calculated that such an accident would not result in unacceptable radiation doses.

The decommissioning aspects of the BONUS facility are further described in Reference 15.

\subsubsection{Walter Reed Research Reactor, Washington, DC}

The Walter Reed Research Reactor was dismantled in 1971. The facility was an Atomics International Model L-54 homogeneous-fuel reactor having a maximum operating power of $50 \mathrm{kWt}$. The reactor was surrounded by a four-story research institute and was housed $20 \mathrm{ft}$ below ground with only limited access via elevators. Heavy duty cranes and equipment could not be used.

The aqueous and solid fuel was removed in special containers. Recombiner unit water and decontamination solutions were solidified in vermiculite and shipped in shielded stainless steel drums. 
A Darda rocksplitter was used to demolish the thick, dense-concrete biological shield. (16) This tool is a hydraulic device that, when inserted into drilled holes, generates very high lateral pressures to establish fracture planes. Conventional road-surface breakers were then used to separate the concrete. Normal research institute operations continued almost uninterrupted during dismantlement and decontamination. Radioactive materials were removed at night and on weekends.

No information is available on costs or on radiological experience. A brief review of the reactor dismantlement is given in Reference 17.

\subsubsection{Pathfinder, Sioux Falls, South Dakota}

Pathfinder was a 66-MWe BWR with integral nuclear superheater that was placed in passive safe storage. The reactor was shut down in 1967, and the plant was converted to conventional operation using three fossil-fueled boilers. The operating license was eventually replaced by a Part 30 byproduct license. The conversion of the turbine cycle equipment was the major activity reported in open literature. (18) Piping and turbine components were decontaminated during the conversion process. Decontamination fluids were placed in barrels, solidified, and shipped for burial. Over $3000.2-\mathrm{m}^{3}$ barrels of solidified waste were removed from the site. Total decommissioning and conversion was estimated to be $\$ 3.7$ million.

\subsubsection{Saxton Nuclear Experimental Facility, Saxton, Pennsylvania}

The Saxton plant was a 23.5-MWt prototype pressurized water reactor that supplied steam to an existing 10-MWe turbo-generator. The reactor was located in the Saxton Steam Generating Station of the Pennsylvania Electric Company and was operated by the Saxton Nuclear Experimental Corporation (SNEC). Decommissioning was accomplished by placing the facility in passive safe storage. SNEC was responsible for all decommissioning activities, including those of contractors. These activities were carried out in accordance with written procedures approved by SNEC. Decommissioning was completed during 1973. 
Prior to decommissioning, an extensive planning program was carried out which included:

- performing an assessment to determine the optimum way of decommissioning the plant

- preparing the decommissioning plan

- iicensing the plan with the AEC.

Additional information of the planning and licensing for the Saxton facility is given in References 19 and 20.

\subsubsection{Experimental Breeder Reactor-1 (EBR-1)}

Idaho National Engineering Laboratory,

Scottsville, Idaho

EBR-1 was the world's first source of nuclear electricity, first demonstrated in 1951. This fast breeder reactor used a sodium-potassium coolant. EBR-1 suffered a core meltdown accident in 1955. It was eventually decided to make EBR-1 the site of a National Historic Monument, and ceremonies took place in 1966. Public access could not be permitted because of radioactive contamination and hazardous accumulations of NaK. Steps to correct this situation were taken in 1973 when a decontamination and decommissioning program was performed. The program plan was performed and completed by Aerojet Nuclear Company, assisted by Allied Chemical Corporation and Argonne National Laboratory.

Information regarding the deactivation steps is given in Reference 21 .

\subsubsection{Elk River Reactor, Elk River, Minnesata}

The Elk River Reactor was a 58-MWt, indirect-cycle, natural-circulation BWR, built under a USAEC contract and operated by the United Power Association (UPA). It was shut down in 1968 after 4 years of commercial operation. UPA waived its option to purchase the plant, and agreement was eventually reached between the AEC and the UPA to dismantle the plant and restore the site as nearly as possible to its original condition. 
The decommissioning program was carried out in three phases: planning, dismantling, and final site closure.

Dismantling was carried out in three overlapping stages:

- removal of the most highly radioactive components (e.g., reactor internals and pressure vessel)

- removal of systems and equipment outside the biological shield that contained low-level contamination

- removal of noncontaminated structures.

It was decided to use plasma-arc cutting under water to dismantle the inner thermal shield and oxyacetylene cutting in air to dismantle the outer thermal shield and the reactor vessel. Plasma-arc cutting was not used on the outer thermal shield because the high temperatures would have vaporized the lead liner. A full test development program was carried out on the cutting processes. A manipulator for remote handling of the cutting torches was developed.

For the removal of concrete, conventional drilling methods were feasible up to a depth of $0.6 \mathrm{~m}$, but were uneconomical because of the time element involved. Controlled use of explosives $(0.7-\mathrm{kg}$ maximum dynamite charges) was successful in safely removing the biological shield, with no release of radioactive contamination. Charge size was limited because the Reactor Building was located close to an operating electrical generating facility.

The total project cost including technical support services was $\$ 6.15$ million. The highest constitutents of costs were material disposal ( $\$ 1.25$ million), removal and disposal of the bio-shield ( $\$ 1.23$ million), and removal and disposal of the reactor vessel ( $\$ 1.06$ million).

The decommissioning activities are further described in References 22 and 23. 


\subsubsection{Peach Bottom 1, York County, Pennsylvania}

Peach Bottom 1, a 40-MWe, high temperature gas-cooled reactor, was shut down in 1974 after 7 years of commercial operation. The decision to decommission was made because of the high cost of modifications required to meet more stringent safety criteria.

A full evaluation of the implications of decommissioning as regards schedule, safety, costs, and licensing was carried out by the utility, Philadelphia Electric Company, and the SUNTAC Nuclear Corporation. Several decommissioning alternatives were considered in light of the following:

- current state and federal licensing problems

- possible changes in regulations

- licensing obligations throughout the life of each option

- cost of disposal of radioactive materials

- cost of preparing the detailed decommissioning plan, technical specifications, safety analysis report, and environmental report for each option

- decontamination requirements for each option

- schedule considerations influencing the availability of operating staff. The resulting decommissioning plan contained manpower details, schedules of activities, safety analyses, proposed surveillance program, and projected final facility status.

The option chosen for Peach Bottom 1 was passive safe storage. Facility preparations took 24 months and involved reducing the controlled access area to include only the Reactor Containment Building. No significant dismantling of this building took place during the preparations for safe storage. Fuel handling equipment was disabled, decontaminated, and stored in place. A11 penetrations into the containment were cut and capped outside the containment wall. A filtered vent was installed to prevent any pressure build-up in the building. 
No special techniques or equipment were required for the preparations. Normal procedures were used to remove fuel and radioactive materials.

Although final costs for the decommissioning of Peach Bottom 1 are not available, the estimated cost obtained from the pre-decommissioning evaluation was just over $\$ 2$ million at 1974 prices for the passive safe storage decommissioning option, including preparation, continuing care period, and subsequent disposal of radioactive materials.

It was reported that no modifications to the original Peach Bottom 1 design would have made decommissioning significantly easier, and it was also felt that this was probably true of large power reactors being constructed at the time. (24) The cost of any radical changes would be significant, and, in any case, existing design features were inherently beneficial when the passive safe storage option was selected.

\subsubsection{Sodium Reactor Experiment (SRE), Santa Susana, California ${ }^{(25)}$}

The SRE was a 20-MWt, sodium-cooled, graphite-moderated thermal reactor located on a site about $45 \mathrm{~km}$ from the center of Los Angeles. It was the first nuclear reactor in the U.S. to produce power for supply to a commercial power grid. It was operated from 1957 to 1964, when nuclear operations ceased and the fuel was removed. Decommissioning began in 1968, with the plant being placed in passive safe storage. Preparations included decontamination of the operating areas, removal of unnecessary equipment and secondary heat transfer sodium, and storage of the primary sodium coolant. Periodic maintenance and surveillance programs were established.

In 1974, planning and preparation for dismantlement began with the establishment of a staff organization to prepare the program plans. The following philosophy guided this effort: nuclear facility dismantling requires engineering, technology, expertise, and control equivalent to that for a construction project and, in fact, requires more care, skill, and creativity to minimize the effects of radiation and other hazardous agents.

A major tooling and technique development program was initiated in 1975 . The development program culminated in techniques for alcohol reaction of sodium 
under well-controlled conditions, design and fabrication of a remotely operated and programmable polar manipulator equipped with a plasma-arc cutting torch, techniques for explosively cutting component piping, and techniques for removing all contaminated and activated components while preserving the Reactor Building and some facility support systems. Peripheral and noncontaminated support systems were removed in parallel with the tooling and technique development work.

The dismantlement activities began in 1976 and proceeded in the following order:

- removal of primary sodium

- removal of internally contaminated auxiliary equipment without dissection

- underwater, explosive cutting of vessel internals and piping connections

- underwater, plasma-arc segmenting of the vessel and thermal liner

- in-air, remote cutting of thermal rings using oxyacetylene torch.

Yet to be completed are the removal of fuel storage cells, wash cells, reactor vessel biological shield and cavity liner, and contaminated soil; the decontamination of the remaining structures; and the restoration of the site and structures to meet physical safety requirements.

Through mid-1978, the dismantlement of the SRE required about $\$ 9$ million (about $\$ 1.5$ million for development), approximately $3,060 \mathrm{~m}^{3}$ of burial space, and about 63 man-rem of exposure.

The dismantling of the SRE is scheduled to be completed in 1979 at an expected total cost of about $\$ 10$ million. $(26)$

\subsubsection{0ther Nuclear Reactor Decommissioning Experience}

Three Oak Ridge National Laboratory (ORNL) reactors were dismantled in 1954 and 1955. (27) These were Homogeneous Reactor Experiments (HRE-1 and HRE-2 reactors) and the Aircraft Reactor Experiment (ARE reactor).

Some of the Hanford Production Reactors have been retired. ${ }^{(28)}$ The reactor structures were considered to be adequate to safely contain the radioactive material inventory. Fuel was removed, cavities were dried, fuel tubes 
were capped, and the control rods were disconnected. Routine surveillance has been provided. One of the retired reactors is scheduled for dismantlement. (29)

Two nuclear power plants unique to military utilization were the U.S. Army's PM-2A and the U.S. Navy's PM-3A. The PM-2A was a 1.5-MWe power reactor system installed at Camp Century, Northern Greenland. It was completely dismantled and removed from its site in $1964 .{ }^{(30)}$ The complete removal of the PM-3A, a 9.4-MWt unit formerly located at McMurdo Station, Antarctica, took about 2 years and was completed in early 1975.

The SL- I Reactor at the Idaho National Engineering Laboratory was completely dismantled following an accident in 1961. (31) High radiation fields and wide-spread contamination complicated the operation. The reactor and the building were completely demolished, and the radioactive wastes were transferred to a local burial ground.

\subsubsection{Decommissioning History of Nonreactor Nuclear Facilities}

Many other nuclear facilities in the U.S., ranging in size from one-room experimental laboratories to prototype fuel reprocessing plants, have been safely decommissioned. A partial listing of some of these facilities is given in Table 4.3-2. In many cases, the precautions and controls necessary for dealing with plutonium, polonium, and radium had to be considered. It should be noted that these considerations are not normally relevant to decommissioning nuclear reactors. From the variety of facilities shown in Table 4.3-2, it is evident that the technology and expertise to decommission any type of nuclear facility has been effectively and safely demonstrated.

\subsubsection{Lessons From Past Decommissionings}

Past decommissionings have demonstrated some of the aspects of the practicality and acceptability of the various decommissioning approaches. The necessary technology not only exists, but has been safely and successfully applied numerous times to a wide variety of nuclear installations. Because of the unique sizes, locations, and conditions under which past decommissionings took place, no two had identical problems or conditions. However, the basic approach to any mode of decommissioning remains virtually unchanged 
TABLE 4.3-2. Nonreactor Nuclear Facility Decommissioning Information

\begin{tabular}{|c|c|c|c|c|}
\hline Facility & Location & $\begin{array}{c}\text { Year } \\
\text { Decommissioned }\end{array}$ & $\begin{array}{c}\text { Type of } \\
\text { Decommissioning }\end{array}$ & Reference \\
\hline $\begin{array}{l}\text { Polonium-210 Facilities } \\
\text { (Units III \& IV) }\end{array}$ & Miamisburg, $\mathrm{OH}$ & 1950 & $\begin{array}{l}\text { Partial Disman- } \\
\text { tlement; decon- } \\
\text { taminated to } \\
\text { release levels }\end{array}$ & 32 \\
\hline $\begin{array}{l}\text { Cave Facility } \\
\text { (Radium-226 and } \\
\text { Actinium- } 227 \\
\text { Processing Facility) }\end{array}$ & Miamisburg, $\mathrm{OH}$ & 1967 & $\begin{array}{l}\text { Partial Entomb- } \\
\text { ment, remainder } \\
\text { decontaminated } \\
\text { to release levels }\end{array}$ & $s$ \\
\hline $\begin{array}{l}\text { SM Facility (Space } \\
\text { Programs Plutonium-238 } \\
\text { Facility) }\end{array}$ & Miamisburg, $\mathrm{OH}$ & 1972 & $\begin{array}{l}\text { Decontaminated } \\
\text { and placed in } \\
\text { Passive Safe } \\
\text { Storage (moth- } \\
\text { balled) awaiting } \\
\text { final disposi- } \\
\text { tion by DOE } \\
\text { (formerly ERDA) }\end{array}$ & 32 \\
\hline $\begin{array}{l}\text { Plutonium Filter Facil- } \\
\text { ity (Building 12) }\end{array}$ & Los Alamos, NM & 1973 & Dismantled & 33 \\
\hline $\begin{array}{l}\text { Laboratory for Plutonium } \\
\text { Criticality Studies } \\
\text { (P-11) }\end{array}$ & Richland, WA & 1974 & Dismantled & 34 \\
\hline $\begin{array}{l}\text { Plutonium Physics Study } \\
\text { Building No. } 21\end{array}$ & Los Alamos, NM & 1975 & Dismantled & 35 \\
\hline
\end{tabular}

(i.e., gathering the manpower, performing the planning and preparation, and implementing the desired decommissioning operations). This fundamental course of events varies only in the numerous plant-specific refinements applied to the various stages of decommissioning. The area of greatest challenge lies in improving job-specific technology, such as remote cutting equipment and decontamination techniques.

Past decommissionings have led to more careful consideration of the socioeconomic impacts on the local communities, the physical impacts on the environment, and the facility design impacts on the facilitation of decommissioning.

Improvements in decommissioning techniques will occur. Witness the development and practical use of plasma-arc cutting techniques and the improvements in explosive techniques employed during the dismantlement of the Elk River Reactor and the Sodium Reactor Experiment. These and other techniques can be expected to be further improved, directly impacting decommissioning costs. 


\subsubsection{Ongoing Experience}

Radiation field buildup effects on personnel exposure are a recognized problem area that can impede operational maintenance and inspection and can impact decommissioning operations. Efforts currently in progress to reduce radiation level buildup include methods for reduction of corrosion product formation in the reactor primary system, methods for cost-effective primary system decontamination, more effective filter and purification systems, and modifications to operational techniques that have a direct influence on radiation fields. The gathering of available data is under way to allow assessment of the overall extent and seriousness of the problem across the industry.

Ongoing industrial programs concerning radiation exposure control and decommissioning include:

- concentrated chemical decontamination at Dresden 1 (BWR with steam generator)

- dilute on-line chemical decontamination at Dresden 2 or Quad Cities 1 and 2 (BWRs)

- steam generator replacement programs at Surry and Turkey Point (PWRs)

- steam generator chemical decontamination at Indian Point 1 (PWR). When completed, these programs will yield significant information on decommissioning (e.g., chemical decontamination methods, steam generator removal technology, and associated exposure reduction techniques).

During reactor operations, the radiation levels in many areas are dominated by radiation from internally contaminated piping and equipment, and minimal efforts, if any, are made to keep structural surface contamination cleaned up. After 40 years of operation, these areas may have fairly high radiation levels. For example, at Dresden 1 it is purported that, although chemical decontamination of the test loop was effective, considerable radiation levels were still present as surface contamination on floors and surrounding structures following that effort. This surface contamination was quite high $(2 \mathrm{R} / \mathrm{hr}$ ), but prior to loop decontamination it was not controlling. 
This phenomenon may well be encountered in BWR decommissioning and may have an effect on the occupational exposures and on the volumes of waste for disposal.

A U.S. Department of Energy (DOE), formerly ERDA, program is establishing methods, costs, and priorities for the decommissioning of retired, contaminated DOE facilities at Hanford. $(37,38)$ Active programs are under way at Hanford to demonstrate the techniques for dismantling and consolidating contaminated equipment and facilities. (39)

In March 1975, the Peach Bottom End-of-Life Program, cosponsored by DOE and EPRI, was initiated. The prime objective of the program is to validate specific reactor design codes by comparison with actual measurements at Peach Bottom 1. Such end-of-1ife research programs, when appropriately correlated with decommissioning planning, can significantly advance nuclear plant design and fuel development technology. (40)

The NRC is currently sponsoring several Pacific Northwest Laboratory research projects that deal with the following aspects of decommissioning:

- long-lived activation products in reactor construction materials ${ }^{(41)}$

- characteristic radionuclide contamination throughout LWR power stations

- decontamination as a precursor to decommissioning. 


\section{REFERENCES}

1. Regulatory Guide 1.86, Termination of Operating Licenses for Nuclear Reactors, U.S. Atomic Energy Commission, June 1974.

2. Decommissioning of Nuclear Facilities, IAEA-179, International Atomic Energy Agency, Vienna, Austria, 1975.

3. K. J. Schneider and C. E. Jenkins, Technology, Safety and Costs of Decommissioning a Reference Nuclear FueT Reprocessing PTant, NUREG-0278, U.S. Nuclear Regulatory Commission Report by Pacific Northwest Laboratory, October 1977.*

4. L. C. Owen, "Current Solid Radwaste Concerns," Trans. Am. Nucl. Soc. 30:557, November 1978 .

5. C. K. Beck, "Intergovernmental Relationships in the Transport of Radioactive materials," Proceedings of the Second Annual Legislative Workshop, CONF-730588, Oak Ridge, TN, May 1973.

6. W. A. Brobst, "The State of State Regulations," Proceedings of the 4th International Symposium on Packaging and Transportation of Radioactive Material, CONF-840901, Miami Beach, FL, September 1974.

7. R. I. Smith, G. J. Konzek and W. E. Kennedy, Jr., Technology Safety and Costs of Decommissioning a Reference Pressurized water Reactor Power Station, NUREG/CR-0130, U.S. Nuclear Regulatory Commission Report by Pacific Northwest Laboratory, June 1978. **

8. G. Lear and P. B. Erickson, "Decommissioning and Decontamination of Licensed Reactor Facilities and Demonstration Nuclear Power Plants," Proceedings of the First Conference on Decontamination and Decommissioning (D\&D) of ERDA Facilities, CONF-750827, pp. 37-45, August 1975.

9. A. Martin, et al., A Prel iminary Study of the Decommissioning of Nuclear Reactor Installations, ANS Report No. 155, Associated Nuclear Services, Epsom, Surrey, England, July 1977.

10. W. Willoughby and H. T. Babb, "CVTR," Nuclear News, 13:48, June 1970.

11. A. Giambusso, "Four Decommissioning Case Histories," Nuclear News, 13:40, June 1970 .

12. W. F. Heine and B. F. Ureda, "Decontamination and Disposition of Hallam and Piqua Reactors," Proceedings of the First Conference on Decontamination and Decommissioning (D\&D) of ERDA Facilities, CONF-750827, p. 139, August 1975.

*Available for purchase from the National Technical Information Service, Springfield, Virginia 22161.

** Available for purchase from the NRC/GPO Sales Program, U.S. Nuclear Regulatory Commission, Washington, D.C. 20555, and the National Technical Information Service, Springfield, Virginia 22161. 
13. Retirement of Hallam Nuclear Power Facility, AI-AEC-12709, Atomics Internationa 1, Canoga Park, CA, May 1970.

14. C. W. Wheelock, Retirement of the Piqua Nuclear Power Facility, AI-AEC12832, Atomics International, Canoga Park, CA, April 1970.

15. Boiling Nuclear Superheater Power Station Decommissioning Final Report, WRA-B-70-500, Docket-1154-2, Puerto Rico Water Resources Authority and United Nuclear Corporation, September 1970.

16. "A World's First: Darda Splitter Used for Dismantling a Reactor," Construction, February 21, 1972.

17. B. G. Bass and E. C. Holman, "The Walter Reed Research Reactor Dismantling Project," Trans. Am. Nucl. Soc., 15:897, November 1972.

18. M. N. Bjeldanes, "PATHFINDER," Nuclear News, 13:56, June 1970.

19. R. J. Reckman and C. R. Montgomery, "Planning and Licensing for the Decommissioning of the Saxton Nuclear Experimental Facility," ASME Publication 73-WA/NE-8, November 1973.

20. Saxton Decommissioning Plan and Safety Analys is Report, AEC Docket No. 50-146/106, Saxton Nuclear Experimental Corporation, General Publ ic Utilities System, Reading, PA, April 1972.

21. J. D. Cerchione, et a1., "EBR-1 and Borax-V Reactor Deactivation," Trans. Am. Nucl. Soc., 8:114, June 1965.

22. R. Blumberg, "Technology for Dismantling Large Radioactive Structural Components," Proceedings of the First Conference on Decontamination and Decommissioning (D\&D) of ERDA Facilities, CONF-750827, p. 71, August 1975.

23. B. J. Davis, "Elk River Reactor Dismantling," Proceedings of the First Conference on Decontamination and Decommissioning (D\&D) of ERDA FaciTities, CONF-75-827, p. 83, August 1975.

24. R. J. Stouky and E. J. Kohler, "Planned Decommissioning of the Peach Bottom Unit 1 High Temperature Gas Cooled Reactor," ASME Publication 73-WA/NE-7, November 1973.

25. G. W. Meyers and W. D. Kittinger, "Progress Report on Dismantling of the Sodium Reactor Experiment," IAEA-SM-234/20, presented at American Nuclear Society Winter Meeting, Washington, DC, November 1978.

26. G. W. Meyers and W. D. Kittinger, "Progress Report on Decommissioning of the Sodium Reactor Experiment," Trans. Am. Nucl. Soc., 30:553, November 1978. 
27. S. E. Bea 11, "Experiences in the Decommissioning and Dismantling of Three ORNL Experimental Reactors," Trans. Am. Nucl. Soc., 8:113, June 1965.

28. S. L. Nelson, "Operational Procedures in Deactivation of the Hanford Production Reactors," Trans. Am. Nucl. Soc., 8:116-117, June 1965.

29. J. F. Nemec, et a1., "Production Reactor Decommissioning - The Planning Phase," Trans. Am. Nucl. Soc., 30:551, November 1978.

30. J. P. Franklin, "Removal of the PM-2A Nuclear Power Plant from Camp Century (U.S. Army)," Trans. Am. Nucl. Soc., 8:117, June 1965.

31. Final Report of SL-7 Recovery Operation, May 1961 through July 1962, ID0-19371 (1962).

32. J. M. Garner, W. P. Davis, "A Summary Review of Mound Laboratory's Experience in D\&D of Radioactive Facilities (1949-1973), "Proceedings of the First Conference on Decontamination and Decommissioning (D\&D) of ERDA Facilities, CONF-750827, pp. 225-231, August 1975.

33. E. L. Christensen, et al., "Demolition of Building 12, An 01d Plutonium Filter Facility," Proceedings of the First Conference on Decontamination and Decommissioning (D\&D) of ERDA Facilities, CONF-750827, pp. 303-324, August 1975.

34. M. N. Raile, "Demolition and Removal of Plutonium-Contaminated Facilities at Hanford," Trans. Am. Nucl. Soc., 22:758, November 1975.

35. E. J. Cox, et al., "Disposition of TA-33-21, A Plutonium Contaminated Experimental Facility, "Proceedings of the First Conference on Decontamination and Decommissioning (D\&D) of ERDA Facilities, CONF-750827, pp. 165-206, August 1975.

36. S. G. Sawochka, N. P. Jacob, and W. L. Pearl, Primary System Shutdown Radiation Levels at Nuclear Power Generating Stations, EPRI 404-2, Electric Power Research Institute Report by Nuclear Water and Waste Technology Corporation, San Jose, CA, December 1975.

37. K. W. Harmon, "PNL Studies of D\&D at Hanford," Proceedings of the First Conference on Decontamination and Decommissioning (D\&D) of ERDA Facilities, CONF-750827, pp. 345-365, August 1975.

38. J. W. Litchfield and J. C. King, Planning for Decommissioning and Decontamination of Hanford Nuclear Facilities, BNWL-SA-6450, Battel7e, Pacific Northwest Laboratories, Richland, WA, September 1977.

39. C. W. Manry, et al., Hanford Production and Waste Management Master Plan, ARH-2956, Atlantic Richfield Hanford Company, Richland, WA, JuTy 1974. 
40. E. J. Kohler, K. P. Steward, and J. V.Iacono, "Peach Bottom Decommissioning and Component Removal," Conference on Reactor Operating Experience, Trans. Am. Nucl. Soc., Vol 26, Supp1. 7, p. 51, August 1977.

41. J. C. Evans, C. L. Wilkerson, R. W. Sanders, and L. A. Rancitelli, "LongLived Activation Products in Reactor Construction Materials, "presented at American Nuclear Society Conference on Decontamination and Decommissioning of Nuclear Facilities, Sun Valley ID, September 1979. 


\section{REGULATORY CONSIDERATIONS FOR DECOMMISSIONING}

In decommissioning, the 1 icensee must be aware of applicable regulatory requirements. This chapter identifies and discusses existing regulations, guides, and standards that apply to decommissioning the reference BWR. The presentation is according to the following phases of decommissioning: planning and preparation, active decommissioning, and continuing care. The conclusions of this chapter follow this presentation.

Regulations and guidelines in this area are dynamic. National policy relating to decommissioning of LWR fuel-cycle facilities is changing, and new regulations are forthcoming. For example, the U.S. Nuclear Regulatory Commission (NRC) is considering the development of a more explicit overall policy for decommissioning nuclear facilities. (1) In addition, it has issued a plan for developing four items related to decommissioning: 1) a general decommissioning policy, 2) the appropriate changes in regulations, 3) the detailed information needed for use in decommissioning decisions, and 4) guidance for the facilitation of decommissioning. (2) The information found in this chapter reflects the current status of federal regulations and guidelines that can be applied to decommissioning the reference BWR. A comprehensive review and analysis of current regulations related to decommissioning of commercial nuclear facilities is given in Reference 3.

\subsection{PLANNING AND PREPARATION}

During the planning and preparation phase of decommissioning prior to final shutdown, the licensee, with NRC approval, decides on and plans how to accomplish the final disposition of the plant. After choosing the appropriate decommissioning mode, the licensee's major preparatory effort is to provide the necessary documentation for amending the facility operating license to a "possession-only" license (and renewing the license) and, if required, for obtaining an NRC dismantling order. 
This section discusses the regulations and regulatory guides that pertain to the planning and preparation phase of decommissioning, in the following sequence: licensing, licensing and insurance costs, and financial qualification.

\section{1 .1 Licensing}

The facility operating license is regulated by 10 CFR Part 50 , (a) Licensing of Production and Utilization Facilities. In 10 CFR 50.51, (b) "Duration of License, Renewal," the operating license is permitted to be valid for a maximum of 40 years. Upon expiration, the 1 icense may be either renewed or terminated. The requirements that must be met to terminate the operating license are presented in 10 CFR 50.82, "Application for Termination of Licenses." Regulatory Guide 1.86 , (c) Termination of Operating Licenses for Nuclear Reactors, amplifies 10 CFR 50.82 and describes the acceptable decommissioning alternatives, as well as the methods for satisfying 10 CFR 50.82. Regulatory Guide 1.86 specifies the procedures and the documentation requirements for amending the facility operating license to a possession-only license and for obtaining a dismantling order. In addition, it delineates the applicability of the possession-only license and the dismantling order to the various decommissioning modes, the surveillance and security requirements if the final decommissioning status requires a possession-only license, and the procedures for terminating the license.

The possession-only license allows the licensee to possess, but not operate, the facility. It permits unloading, storing, and subsequent shipping of the spent reactor fuel, as well as the minor work associated with preparation for custodial safe storage or passive safe storage. It is the governing license in all decommissioning modes, but a dismantling order is also required in the case of dismantlement or preparations for hardened safe storage or entombment. The possession-only license, or an agreement-state byproduct license, remains in force during the continuing care period of safe storage or entombment, and must be renewed every 40 years.

(a)Acronym for U.S. Code of Federal Regulations, Title 10, Part 50 (typical). (b)Acronym for Section 50.51 of 10 CFR Part 50 (typical).

c) Regulatory Guides in this appendix refer to those issued by NRC. 
The possession-only license deletes the technical specifications regarding plant operation (and associated surveillance requirements) that are not applicable to decommissioning, but maintains those that are necessary to ensure protection of the workers and the public during decommissioning. It also contains the authority to possess and handle byproduct material, source material, and special nuclear material as governed by 10 CFR Part 30, Rules of General Applicability to Licensing of Byproduct Material, 10 CFR Part 40, Licensing of Source Material, and 10 CFR Part 70, Special Nuclear Material.

In requesting to amend a facility operating license to a possessiononly license, the licensee must provide the following information, as specified by Regulatory Guide 1.86:

- a description of the current status of the facility

- an inventory of the radioactive materials and their location in the facility

- a description of the decommissioning activities to be performed

- a description of measures to be taken to prevent criticality or reactivity changes and to minimize releases of radioactivity from the facility

- any proposed changes to the technical specifications that reflect the possession-only facility status and the decommissioning activities to be performed

- a safety analysis of both the activities to be accomplished and the proposed changes to the technical specifications.

This information becomes the decommissioning plan for custodial safe storage or passive safe storage.

If major plant changes are planned (as is the case with preparations for hardened safe storage, with preparations for entombment, or with dismantlement), an NRC dismantling order is required to proceed. The request for a dismantling order must be accompanied by a dismantlement plan that includes, but is not 
limited to, the following information, as specified by 10 CFR 50.82 and clarified in Regulatory Guide 1.86:

- a description of the ultimate status of the plant

- a description of the dismantling activities, including radioactive waste disposal and site decontamination, and the associated environmental and safety precautions

- a safety analysis of the dismantling activities, including any effluents that may be released

- a safety analysis of the plant in its ultimate status.

Regulatory Guide 1.70, Standard Format and Content of Safety Analysis

Reports for Nuclear Power Plants, Regulatory Guide 4.2, Preparation of Environmental Reports for Nuclear Power Plants, and References 4 and 5 may be of interest to the licensee during preparation of the license amendment request and the dismantlement plan.

If 1 icense expiration is imminent, a request for renewal should be submitted with the amendment application. The renewal process defined by 10 CFR 50.51 is not specific as to procedural and documentational requirements. However, the license renewal request will presumably require the same review process and, thus, the same informational input as the license amendment application. Hence, a combined license amendment and license renewal request is both cost and time effective.

The following subsections deal with the regulations and regulatory guides that pertain to the documentational requirements of a license amendment request or a dismantlement plan.

\subsubsection{Radioactive Waste Handling Plan}

Regardless of the decommissioning mode, radioactive waste will be accumulated, treated, packaged, stored, and transported to a disposal site. Small quantities of radioactive liquid or gaseous effluents may be released at the site, in accordance with existing regulations. Regulations defining 
the requirements for protecting the public and the decommissioning workers during such activities are found in 10 CFR Part 50, Licensing of Production and Utilization Facilities, 10 CFR Part 20, Standards for Protection Against Radiation, and 10 CFR Part 71, Packaging of Radioactive Materials for Transport and Transportation of Radioactive Material Under Certain Conditions. Means for complying with these regulations must be defined in the license amendment request or the dismantlement plan. These are the same requirements that the licensee must address in his application to construct and operate a BWR.

\subsubsection{Quality Assurance Plan}

As part of the 1 icense amendment request or the dismantlement plan, quality assurance of the decommissioning activities should be addressed "... to prevent or mitigate the consequences of postulated accidents that could cause undue risk to the health and safety of the public," as stated in 10 CFR Part 50 , Appendix B, "Quality Assurance Criteria for Nuclear Power Plants and Fuel Reprocessing Plants." The requirements in Appendix B pertain to such topics as design, purchasing, and fabrication, but do not specifically address decommissioning. Additional guidance is also found in the NRC's Standard Review Plan, Section 17.1, "Quality Assurance During the Operating Phase" (4) and in Regulatory Guide 1.143, Design Guidance for Radioactive Waste Management Systems, Structures, and Components Installed in Light-Water-Cooled Nuclear Power Plants. The principles and objectives of such guidance should be applied to all décommissioning activities.

\subsubsection{Security and Safeguards Plans}

Security and safeguards plans should be part of the license amendment request or the dismantlement plan. Although security and safeguards during decommissioning are not specifically addressed in the regulations, the intent of the regulations for operating plants remains the same during decommissioning, insofar as they apply. These subjects are discussed in 10 CFR 50.34 (c), "Physical Security Plan," Regulatory Guide 1.17, Protection of Nuclear Power Plants Against Industrial Sabotage, and 10 CFR Part 73, Physical Protection of Plants and Materials. 


\subsubsection{Environmental Plans}

The environmental information that is supplied with the license amendment request or the dismantlement plan should satisfy the requirements of 10 CFR Part 51, Licensing and Regulatory Policy and Procedure for Environmental Protection, and the intent of Section 51.21, "Applicant's Environmental Report - Operating License Stage." It states in 10 CFR $51.5(\mathrm{~b})(7)$ that license amendments or dismantling orders authorizing decommissioning may or may not require an NRC environmental impact statement. If judged that such is not required, a negative declaration and an environmental impact appraisal must be prepared by the NRC in accordance with 10 CFR 51.7 and 10 CFR 51.50 (d). (a)

\subsubsection{Licensing and Insurance Costs}

Other considerations of significant concern, mainly to the licensee, are the cost of licensing fees and the cost of the insurance that is required during decommissioning. These costs are dictated by the type and quantity of radioactive and/or special nuclear materials involved, the type of operation being conducted, and, correspondingly, the type of license.

Licensing fees are addressed in 10 CFR Part 170. The schedule of fees for facility operating license amendments and renewals is listed in 10 CFR 170.22. The schedule of fees for routine inspections are listed in 10 CFR 170.23 and 10 CFR 170.24.

The financial protection requirements during plant operation are given in 10 CFR Part 140 . The levels of protection required during decommissioning are not specifically defined.

\subsubsection{Financial Qualification}

The financial qualification of the licensee is an important area considered by the NRC during the review of an operating license application and each year thereafter. Regulations covering this area are found in 10 CFR 50.33(f) and Appendix $C$ of of 10 CFR Part 50. Both address the necessity of sufficient funds to operate the facility " ... for the period of the license or for 5 years,

(a)A negative declaration is a document prepared by the NRC that states that it has decided not to prepare an environmental impact statement for a particular action, and that an environmental impact appraisal setting forth the basis for that determination is available for public record. 
whichever is greater, plus the estimated cost of permanently shutting the facility down and maintaining it in a safe condition." However, neither specifically addresses decommissioning of the facility. Appendix $F$ of 10 CFR Part 50, al though intended specifically for fuel reprocessing plants, states that the license application shall include information showing that the applicant is financially qualified "... to provide for the removal and disposal of radioactive wastes, during operation and upon decommissioning of the facility."

\subsection{ACTIVE DECOMMISSIONING}

Active decommissioning begins immediately following final plant shutdown, and consists of either dismantlement, preparations for safe storage, or preparations for entombment. This section discusses the regulations, regulatory guides, and national standards that apply to the basic aspects of active decommissioning of the reference BWR. Most of these basic aspects are similar in nature to many of plant operation; and the regulatory controls and national standards that govern plant operation of these aspects also apply to active decommissioning, although very few of them specifically mention decommissioning activities. The basic areas of active decommissioning are: 1icensing, occupational radiation safety, public radiation safety, special nuclear material handling, radioactive waste handling, industrial safety, and license termination and facility release.

\subsubsection{Licensing}

The possession-only license is regulated generally by 10 CFR Part 50, Licensing of Production and Utilization Facilities and specifically by 10 CFR 50.82, "Application for Termination of Licenses." Further guidance on the general limitations of the possession-only license is given in Regulatory Guide 1.86, Termination of Operating Licenses for Nuclear Reactors.

Situations that exceed the limitations of the possession-only license may arise during the course of active decommissioning. (Regulatory Guide 1.86 refers to these situations as "unrelated safety questions.") This type of situation is regulated by 10 CFR 50.59, "Changes, Tests and Experiments." 


\subsubsection{Occupational Radiation Safety}

Because of the highly radioactive materials and contaminated work locations in the reference BWR during active decommissioning, occupational radiation exposure control is of major importance. 0ccupational radiation safety is regulated by 10 CFR Part 20, Standards for Protection Against Radiation. The maximum permissible limits for occupational radiation exposure are presented in 10 CFR 20.101, "Exposure of Individuals to Radiation in Restricted Areas, and 10 CFR 20.103, "Exposure of Individuals to Concentrations of Radioactive Materials in Air in Restricted Areas." However, these limits are tempered by the operating philosophy of As Low As is Reasonably Achievable (ALARA) as explained in 10 CFR 20.1(c). This philosophy is described in Regulatory Guide 8.8, Information Relevant to Ensuring that Occupational Radiation Exposure at Nuclear Power Stations will be As Low As Reasonably Achievable, and in Regulatory Guide 8.10, Operating Philosophy For Maintaining Occupational Radiation Exposure As Low As Is Reasonably Achievable.

Additional information on how to comply with the ALARA concept can be found in the NRC Standard Review Plan, Section 12.1, "Assuring That Occupational Radiation Exposures Are As Low As Is Reasonably Achievable." ${ }^{(4)}$ Besides 10 CFR Part 20 and Regulatory Guide 8.8 some of the more relevant regulations and guidance cited in Section 12.1 are given below:

- 10 CFR Part 19, Notices, Instructions and Reports to Workers; Inspections

- Regulatory Guide 1.8, Personnel Selection and Training

- Regulatory Guide 1.16, Reporting of Operating Information

- Regulatory Guide 1.39, Housekeeping Requirements for Water Cooled Nuclear Power Plants

- Regulatory Guide 8.2, Guide for Administrative Practices in Radiation Monitoring

- Regulatory Guide 8.3, Film Badge Performance Criteria

- Regulatory Guide 8.6, Standard Test Procedures for G-M Counters 
- Regulatory Guide 8.7, Direct Reading and Indirect Reading Pocket Dosimeters

- Regulatory Guide 8.9, Acceptable Concepts, Models, Equations and Assumptions for a Bioassay Program

- ANSI N13.12, Control of Radioactive Surface Contamination of Material, Equipment and Facilities to be Released for Uncontrolled Use, American National Standards Institute (Published for national trial and use in 1978)

- ANSI N18.9-1972, Administrative Controls for Nuclear Power Plants, American National Standards Institute (1972)

- ANSI Z88.20-1969, Procedures for Respiratory Protection, American National Standards Institute (1969)

- USBM-23, Respiratory Protective Services for Use in Atmospheres Containing Radioactive Materials, U.S. Bureau of Mines (1973).

\subsubsection{Public Radiation Safety}

Public radiation exposure that results from decommissioning the reference BWR must also comply with 10 CFR Part 20. The maximum public exposure limits for external exposure are specified in 10 CFR 20.105, "Permissible Levels of Radiation in Unrestricted Areas." Limits for internal exposure pathways are given in 10 CFR 20.106 "Radioactivity in Effluents to Unrestricted Areas." As in the case of occupational exposure, 10 CFR 20.1 (c) requires application of the ALARA principle to the control of public radiation exposures and releases of radioactive materials to the environs. Appendix I of 10 CFR Part 50 provides numerical guides for establishing design objectives and limiting conditions of operation in order to meet the ALARA criterion for radioactive materials in effluents from operating light-water reactors. (Although Appendix I applies specifically to gaseous and liquid effluents from an operating light-water reactor, the possession-only license will undoubtedly require adherence during decommissioning.)

The Environmental Protection Agency (EPA) is in the process of assuming the lead role in regulating public radiation exposure. The EPA public radiation 
exposure 1imits, defined in 40 CFR Part 190, Environmental Radiation Protection Standards for Nuclear Power Operations, are now in effect.

As presently written, the EPA limits apply to uranium fuel-cycle operations that directly support the production of electricity, but not to waste management. Limits for waste management are being developed and may well apply to decommissioning. When in effect, the EPA limits, which are more restrictive for direct external exposure than those in 10 CFR 20.105, will govern all aspects of public radiation exposure. (The appropriate sections of 10 CFR Part 20 are being revised to reflect this.) However, since Appendix I of 10 CFR Part 50 is more restrictive than 40 CFR Part 190 for internal exposure from light-water reactors effluents, Appendix I will guide this aspect for light-water reactors.

\subsubsection{Special Nuclear Materials Handling}

Safeguards and security precautions must continue after plant shutdown until all special nuclear materials that come under regulatory control are removed from the plant. Regulations defining the required precautions are found in 10 CFR Part 70, Special Nuclear Materials, and 10 CFR Part 73, Physical Protection of $\mathrm{Plant}$ Materials. The highly radioactive nature of the remaining special nuclear material (i.e., irradiated fuel) makes its theft very unlikely. The principal concern is to protect against acts of sabotage that could endanger the safety of the work force and the public.

As the final step in disposing of the fuel, a final cumulative Material Unaccounted For (MUF) value must be established. This is generally not too difficult, since it is based on a piece count of the fuel rods. Likely sources of MUF at a BWR are misplaced fuel rods and pellets lost from severely damaged fuel rods, all of which will most probably be found as the spent fuel pool is emptied.

\subsubsection{Radioactive Waste Handling}

The decommissioning of a BWR entails the disposal of radioactive materials. Little guidance currently exists on the final disposition of the highly radioactive reactor vessel components and other highly contaminated pieces of equipment. Shallow-land burial of these "high-level" wastes is currently 
being reviewed. A review of the regulations that pertain to the licensing and operation of radioactive waste disposal facilities is not in the scope of this study. Reference 6 discusses this matter in detail.

Regulations that govern the packaging and transport of radioactive materials are designed to prevent the dispersal of radioactivity to the environs and to protect the public and the transportation workers during shipment. There is some overlapping of federal responsibility for regulating the safe packaging and transport of radioactive materials. This responsibility lies primarily with the Department of Transportation (DOT) and secondarily with the NRC. A "Memorandum of Understanding" between DOT and NRC, signed in 1966 and revised in 1973, calls for cooperation and delineates the responsibilities of each agency.

The DOT is responsible for safety standards governing packaging and shipping containers and for their labeling, classification, and marking. The NRC develops performance standards and reviews designs for Type $B$, fissile, and large-quantity packages. The DOT requires NRC approval to use these packages. (8) The DOT also implements safety standards for the mechanical condition of carrier equipment and for the qualifications of carrier personnel. The Federal Aviation Administration (FAA), the Interstate Commerce Commission (ICC), and the U.S. Coast Guard also exercise some regulatory authority over the shipment of radioactive materials.

The following federal regulations are applicable to the packaging and transport of radioactive materials:

- 10 CFR Part 71 - NRC regulations for packaging and shipment of radioactive materials

- 10 CFR Part 73 - NRC regulations for the protection of special nuclear material in transit

- 14 CFR Part 102 - FAA regulations for shipment of radioactive materials by air

- 47 CFR Parts 146 and 149 - U.S. Coast Guard Regulations governing the shipment of radioactive materials by water 
- 49 CFR Parts 170 to 199 - DOT regulations regarding the transport of hazardous materials.

The U.S. Department of Energy (formerly ERDA) has prepared a more detailed review of the regulations pertaining to the transport of radioactive material.

\subsubsection{Industrial Safety}

During active decommissioning of a BWR, industrial safety (i.e., not related to radiation safety) and occupational work conditions are regulated by the Occupational Safety and Health Administration of the U.S. Department of Labor under 29 CFR Parts 1900 to end.

\subsubsection{License Termination and Facility Release}

One of the goals of decommissioning the reference BWR is to terminate the 7 icense and release the plant for unrestricted use. To do this, the residual radioactive contamination must be at an acceptable level for public protection. Several attempts have been made to define the acceptable residual radioactive contamination levels for unrestricted use of materials, but no allencompassing regulatory position is available. Because of this, Chapter 8 of this report presents a suggested methodology for determining acceptable levels for unrestricted release of the reference BWR.

Guidance on acceptable residual contamination levels is found in Regulatory Guide 1.86 and the proposed ANSI Standard N13.12, Control of Radioactive Surface Contamination on Materials, Equipment and Facilities to be Released for Uncontrolled Use. Additional guidance can be inferred from information developed for plutonium in soils. $(10,11)$ The EPA is in the process of finalizing its guidance on the environmental limits for unrestricted use of soils contaminated with transuranium elements.

Termination of the possession-only license is regulated by 10 CFR 50.82, with guidance on procedural matters presented in Regulatory Guide 1.86.

\subsection{CONTINUING CARE}

Continuing care deals with surveillance and maintenance of the plant in a safe storage mode or in entombment. Primary concerns during this period are for public and occupational safety and for licensing. 


\subsubsection{Public and 0ccupational Safety}

Requirements for public and occupational safety during the continuing care phase of decommissioning remain identical to those during active decommissioning (see Sections 5.2.2 and 5.2.3). The requirements in this area are specified by the possession-only license, which likely will not be changed for continuing care.

\subsubsection{Licensing}

The NRC possession-only license, which is regulated by 10 CFR Part 50 remains in force during continuing care (see Regulatory Guide 1.86). Alternatively, the NRC's regulatory authority for the continuing care situation can be relinquished to an agreement state under 10 CFR. Part 150, Exemptions and Continued Regulatory Authority in Agreement States Under Section 274. Section 274(b) of the Atomic Energy Act of 1954, as amended, requires agreement state programs to be compatible with NRC regulations. The NRC requires that agreement state programs reflect the NRC's lead in the area of decommissioning.

The license and premises can be transferred to another organization that will provide continuing care services. If the other organization is already licensed to handle radioactive materials, procedures for license transfer that are given in Regulatory Guide 1.86 can be used; if not, 10 CFR 50.80, "Transfer of Licenses," regulates the transfer.

A maximum license duration of 40 years is specified by 10 CFR 50.51, "Duration of License, Renewal." License renewal is also regulated by 10 CFR 50.51 , al though no renewal procedure is stipulated.

Regulatory Guide 1.86 and 10 CFR 50.82 present the guidance and regulations for terminating the license at the end of the continuing care period. In most cases, some dismantlement will be required to ensure that the contamination levels in the plant are at or below acceptable residual contamination levels. The regulatory requirements discussed in Section 5.2 of this chapter will apply in these cases. A dismantling order, discussed in Section 5.1.1 of this chapter, is also required in these cases. 


\subsection{CONCLUSIONS}

This review of existing regulations and guidelines shows that, in general, regulations are in place to cover the subject of decommissioning of the reference BWR. In some cases (security, safeguards, quality assurance), the existing regulations do not speak specifically to the question of decommissioning, but they can readily be interpreted as being applicable.

The following suggestions are made for improving present regulations:

- Centralize or provide an index for all regulations that pertain to decommissioning.

- Modify the existing regulations that apply to decommissioning to include reference to such application.

- Clearly define the financial qualifications and responsibilities of the 1 icensee for decommissioning.

- Specify which of the existing regulations that govern public radiation dose take precedence during the decommissioning of a light-water reactor.

- More clearly define "high-level waste" (with respect to the highly radioactive reactor vessel components) and the associated disposal requirements.

- Provide a common, identifiable source of acceptable residual radioactive contamination levels for unrestricted release of materials, structures, and sites.

- Specify the license renewal requirements for and during decommissioning. Other $i$ tems that need consideration are:

- decommissioning facilitation

- decommissioning plans prior to plant construction

- general decommissioning philosophy. 


\section{REFERENCES}

1. Federal Register, Vol. 43, No. 49, p. 10371, March 13, 1978.

2. Plan for Reevaluation of NRC Policy on Decommissioning of Nuclear Facilities, NUREG-0436, Revision 1, Office of Standards Development, U.S. Nuclear Regulatory Commission, December 1978.*

3. A. H. Shilling et al, Decommissioning Commercial Nuclear Facilities: A Review and Analys is of Current Regulations, NUREG/CR-0677, U.S. Nuclear Regulatory Commission Report by Pacific Northwest Laboratory and Battelle Human Affairs Research Centers, August 1979.*

4. Standard Review Plan for the Review of Safety Analysis Reports for Nuclear Power Plants, NUREG-75/087, Office of Nuclear Reactor

Regulation, U.S. Nuclear Regulatory Commission, September 1975. **

5. Environmental Standard Review Plans for the Environmental Review of Construction Permit Application for Nuclear Power Plants (Draft), NUREG-0158, Office of Nuclear Reactor Regulation, U.S. Nuclear

Regulatory Commission, January 1977. (Free upon written request from the USNRC, Division of Technical Information and Document Control, Wash.,DC 20555.)

6. J. J. Cohen et al., Determination of Performance Criteria for HighLevel Solidified Nuclear Waste, NUREG-0279, Lawrence Livermore Laboratory for U.S. Nuclear Regulatory Commission, July 1977. **

7. C. K. Beck, "Intergovernmental Relationships in the Transport of Radioactive Materials," Proceedings of the Second Annual Legislative Workshop, CONF-730588, May 1973.

8. W. M. Rogers, Jr., "State and Federal Roles in Regulating the Transportation of Radioactive Materials," Proceedings of the 4th International Symposium on Packaging and Transportation of Radioactive Material, CONF-740901, September 1974.

9. U.S. Energy Research and Development Administration, Alternatives for Managing Wastes from Reactor and Post-Fission Operations in the LWR Fuel Cycle, ERDA 76-43, Vol. 5, Appendix 3, May 1976.

10. J. W. Healy, A Proposed Interim Standard for Plutonium in Soils, LA-5483-MS, Los Alamos Scientific Laboratory, Los Alamos, NM, January 1974.

11. A. J. Hazle and Bert L. Crist, Colorado's Plutonium-in-Soil Standard, Colorado Department of Health, Occupational and Radiological Health Division, Denver, C0, 1975.

12. U.S. Environmental Protection Agency, Proposed Guidance on Dose Limits for Persons Exposed to Transuranium Elements in the General Environment, EPA 520/4-77-016, September 1977.

*Available for purchase from the NRC/GPO Sales Program, U.S. Nuclear Regulatory Commission, Washington, D.C. 20555, and the National Technical Information Service, Springfield, Virginia 22161.

Available for purchase from the National Technical Information Service, Springfield, Virginia $22161 . \quad 5-15$ 
• 


\section{FINANCING OF DECOMMISSIONING}

This chapter discusses alternative approaches to providing funds for decommissioning a BWR power station. Only alternative financial mechanisms for ensuring the availability of adequate funds are discussed. Legal-institutional issues (e.g., who should collect the funds and how the funds should be administered) are outside the scope of the study and are not considered. The discussion in this chapter is qualitative in nature, and numerical examples are relegated to Appendix A.

At the present time, the federal government has very little direct involvement in decommissioning financing considerations. NRC regulations simply require the applicant for an operating license to demonstrate the financial resources to cover the estimated costs of both operating and permanently shutting down the facility. (1) However the importance of financial assurance for decommissioning was recently recognized by the Congress of the United States in the Uranium Mill Tailings Control Act of 1978. (2) This act amends the Atomic Energy Act of 1954, providing explicit authority for NRC to require an adequate bond, surety, or other financial arrangement by uranium mill licensees to ensure site cleanup and reclamation prior to license termination. Furthermore, NRC is considering financial requirements within the broader context of an overall reevaluation of its policies on decommissioning nuclear facilities.

\subsection{NEED FOR ASSURANCE OF DECOMMISSIONING FUNDS}

Both federal and state governments have the responsibility to protect the health and safety of their citizens. In connection with this responsibility, a state in which a nuclear power plant is located has several financial concerns. It is concerned with the utility having sufficient funds to decommission the plant after shutdown and the availability of funds for unexpected contingencies during both plant operation and plant decommissioning. If the utility defaults or goes bankrupt, the state may have to assume financial responsibility for decommissioning. 
Two factors combine to provide a reasonably high degree of certainty that a utility will be financially capable of decommissioning a nuclear power plant. Utilities generally have significant assets and, because of their regulated monopoly status, are allowed to recover their expenses and earn a reasonable return on their capital investment. Moreover, public interest considerations relating to utilities essential services to society suggest that a utility would not be allowed to become insolvent except in very rare instances. For certain non-investor-owned utilities with the ability to raise funds through taxes (e.g., certain municipal utilities), the argument against insolvency is especially convincing. Nevertheless, some form of financial assurance for decommissioning may be desirable. First, since most nuclear power plants are expected to operate 30 to 40 years and ultimate decommissioning may be delayed 50 to 100 years following final shutdown, predicting the financial stability of the utility involved is uncertain at best. Second, the utility may postpone decommissioning because it has no direct economic incentive to decommission a shutdown plant. Finally, a severe accident such as occurred at Three Mile Island Generating Station II in March, 1979, may financially cripple even a large, well-insured utility. For these reasons, there is a need to take steps to ensure the availability of funds for decommissioning.

\subsection{ALTERNATIVE APPROACHES FOR PROVIDING DECOMMISSIONING FUNDS}

Ensuring the availability of funds for decommissioning after a nuclear power plant has ceased to produce any revenue should be addressed prior to plant startup. The eventual cost of decommissioning should be considered as much a part of nuclear power generation costs as is the cost of fuel, and decommissioning costs should be borne equitably by the consumers of the power produced during plant operation.

NRC is considering five criteria to evaluate the relative effectiveness of alternative decommissioning financing methods. ${ }^{(4)}$ These criteria are:

1. the degree of decommissioning assurance provided;

2. the cost of providing the assurance;

3. the extent to which the consumers of the plant's power equitably share the costs of decommissioning; 
4. the flexibility to respond to changes in inflation and interest rates, reactor life, and estimated decommissioning costs; and

5. the ability to accommodate different ownership and jurisdictional arrangements .

Criterion 1 is considered most important; criteria 2 and 3 are next in importance; and criteria 4 and 5 must be met for a financing alternative to receive further consideration. ${ }^{(4)}$

There are three principal financing alternatives for decommissioning a nuclear power station that satisfy the above criteria to varying degrees:

- a prepaid decommissioning reserve controlled by an outside entity

- an internal decommissioning reserve, either funded or unfunded

- a funded reserve or sinking fund controlled by an outside entity.

Combinations of these alternatives can also be used. These alternatives are discussed in the following subsections. A fourth alternative, payment of decommissioning costs from utility revenues when the funds are required, is considered in less detail because it fails to meet criteria 1 and 3 . Other alternatives, such as bonding or insurance pools, are considered briefly, principally in regard to decommissioning after a premature shutdown.

\subsubsection{Prepaid Decommissioning Reserve}

This alternative involves payment of the total expected decommissioning cost (in year-of-startup dollars) to an outside entity prior to the start of operations at the nuclear power plant. The funds remain completely outside the control of the utility during the operating lifetime of the plant. The outside entity invests and manages the funds until needed for decommissioning. No states are known to use this financing approach at the present.

Ideally, the outside entity would be an agency of the state. This arrangement not only provides stability in the care and management of the funds but could also provide a significant tax advantage. The Internal Revenue Service (IRS) does not tax income accruing to the government of any political subdivision of the U.S. ${ }^{(5)}$ A state agency might therefore be able to invest the decommissioning proceeds in high-yielding treasury bills or in secure 
industrial bonds without tax liability for the interest earned. Historically, this type of investment has yielded a real return of 1 to $3 \%$ per year (i.e., a return of 1 to $3 \%$ per year greater than the rate of inflation). Although this return has not been obtainable at certain times in recent years, there is still a strong likelihood that a state agency not subject to federal taxes can invest the funds so the rate of growth of the decommissioning reserve at least matches the rate of decommissioning cost escalation due to inflation.

For federal income tax purposes, it is unlikely that the money paid to the outside entity by an investor-owned utility can be treated as expenses in the year of payment since the payment is actually a prepaid expense. The IRS generally requires payments of this type to be capitalized and amortized in the same way as is the capital cost of the plant. Thus, the decommissioning cost prepayment and the plant capital cost would be included in the rate base, and capital recovery would be accomplished via normal depreciation accounting methods.

The prepayment financing alternative meets the five selection criteria reasonably wel1. Of the three discussed financing alternatives, this alternative provides the greatest assurance that decommissioning funds will be available. If the fund is not subject to federal taxes, the return realized could exceed the utility's after-tax cost of capital, suggesting that the consumer may benefit more by having the funds in an outside escrow account than by having the funds reinvested in the utility's capital structure. This approach is equitable to electricity consumers because the revenues to recover the prepaid expense are collected over the entire operating life of the plant. The prepaid financing approach seems to satisfy criterion 5 and can satisfy criterion 4 as long as the responsible regulatory agency has the power to direct the utility to make future payments to the fund if estimated decommissioning costs escalate faster than the fund's return on investment.

\subsubsection{Internal Unfunded Decommissioning Reserve}

An internal unfunded decommissioning reserve is the approach most prevalent in states with nuclear power plants. The most common procedure is to add the estimated cost of decommissioning as a negative salvage value to the original 
cost of the plant. Each year, the utility credits an unfunded reserve for decommissioning from operating revenues. At the end of the plant's operating life, the total accumulated negative salvage value depreciation is to equal the estimated cost of decommissioning (in year-of-startup dollars).

For investor-owned utilities, the recovery of future decommissioning expenses is complicated by federal tax regulations. Revenues collected for the decommissioning reserve are considered as taxable income. (6) However, the expense of decommissioning is presently not deductible until it is incurred (i.e., after plant shutdown). (7) Conceptually, the revenue requirements for this financing approach can be set so the sum of the after-tax revenues each year, compounded at the utility's after-tax cost of capital, provide the required after-tax decommissioning funds.

The chief disadvantage of the internal decommissioning reserve is the relative lack of decommissioning assurance as compared to the other two financing options, particularly with respect to premature decommissioning. From a cost and equity standpoint, it is difficult to generalize conclusions since the analysis is quite dependent both on taxing and accounting practices and on financial assumptions. A principal advantage of this approach is that it fits easily into existing rate-making practices and does not require a new entity to oversee or manage the decommissioning funds.

\subsubsection{Sinking Fund Payment to an Outside Escrow Account}

Under this financing option, the utility makes periodic payments to an outside escrow account, where the funds are invested in securities until they are needed for decommissioning. At least one state, Pennsylvania, has adopted this financing method.

If the escrow account is managed by a state agency, there is a good possibility that the income generated by the escrow account will not be subject to federal income taxes. It may also be possible to structure the account so an investor-owned utility's payments can be made from untaxed revenue. (4) If the escrow payment is not taxed, the utility's annual revenue requirement is simply equal to the annual payment. 
This approach seems to satisfy all five evaluation criteria reasonably well. It provides the flexibility needed to meet criteria 4 and 5. It provides reasonable assurance of the availability of decommissioning funds, with the principal risk being that a plant may be shutdown prematurely before adequate funds are collected. This approach is reasonably equitable, and payments to the fund can fluctuate with inflation so consumers are paying for decommissioning in dollars of constant purchasing power. The relative cost of this al ternative is subject to assumptions on tax, accounting, and financial practices.

\subsubsection{Payment from Revenue when Needed}

Under this option, the utility takes no action until the funds are needed for decommissioning. At that time, the decommissioning costs are paid out of current revenues. The costs are an allowable expense, thus no income taxes are paid on that portion of the revenue. Exactly how this approach would be handled with regard to the utility's rate structure is unclear.

This option has the same disadvantage as the internal reserve option, a relative lack of assurance that the funds will be available. It has the additional disadvantage that the costs will be borne by people who do not benefit from the plant's operation.

\subsection{FINANCIAL PROVISIONS FOR PREMATURE PLANT SHUTDOWN}

With the last three funding alternatives, there is a risk that sufficient funds will not be available to pay for decommissioning if the nuclear power plant is shutdown prematurely. If the utility is financially unable to provide the funds needed for decommissioning, the state or federal government may have to pay for these activities. Several options are available to reduce this risk of unavailability of funds in the event of premature shutdown. These include one or more of the following:

- a large initial payment to a sinking fund prior to plant startup

- higher per-unit payments (in constant-value dollars) to a sinking fund during the early years of plant operation 
- a surety bond posted by the utility

- a decommissioning assurance insurance pool.

These risk-reducing options are discussed in the following subsections.

\subsubsection{Large Initial Payment}

A large initial cash payment is made to the sinking fund prior to plant startup. The size of the payment is flexible and depends on a number of factors, including the financial resources of the utility, the probability of premature shutdown, the extent of anticipated funding problems, and the anticipated operating life of the facility. An initial payment of about 10 to $20 \%$ of the total estimated decommissioning costs (in year-of-startup dollars) might be required.

The principal advantage of this option is the increased assurance it provides for meeting decommissioning costs. The principal disadvantage is the possibility of financial hardship on the utility, as under the prepayment funding alternative. A lesser disadvantage is the potential for inequitable distribution of decommissioning costs among the power consumers.

\subsubsection{Higher Initial Sinking Fund Payments}

For this option, payments to the sinking fund (in constant-value dollars) are initially higher than the average unit cost and then decline with time. The precise sliding scale is determined by the state utility commission and the utility. One possible approach is to maintain fixed payments in nominal dollars over the lifetime of the facility, with the payments based on costs estimated in year of decommissioning dollars. This option can be combined with the largeinitial-payment option.

The advantages and disadvantages of this option are comparable to those of the large-initial-payment option. This option's main advantage is the added assurance that adequate funds are available for decommissioning in the event of premature shutdown. A disadvantage is that power consumers during the early years will pay a disproportionate share of the decommissioning expenses. 


\subsubsection{Surety Bond}

This option requires the utility to post surety bond (performance bond). The main problem with this is the difficulty of obtaining a long-term commitment of this magnitude from a surety company. If a utility is somehow able to obtain a bond, it may have to provide $100 \%$ collateral. ${ }^{(8)}$ Another problem is the cost of a bond, which is likely 1 to $2 \%$ per year of the guaranteed amount. (9) This represents a significant cost burden on the power consumers.

A surety bond has two advantages. First, it is potentially manageable (less burdensome) for a small company that is unable to make a large initial cash payment. Second, it distributes decommissioning costs to the power consumers more equitably than a large initial cash payment.

\subsubsection{Insurance Pool}

This option for ensuring adequate premature decommissioning funding requires utilities (and operators of other nuclear fuel-cycle facilities) to make payments into a decommissioning assurance pool. The pool is obligated to pay for a decommissioning a facility if the operator defaults. One problem with this option is the setting of appropriate premiums. To establish premiums, the pool administrator is required to estimate the likelihood of nonperformance or partial performance and the magnitude of the fund required to offset anticipated funding shortfalls. Another problem is the probability that a decommissioning assurance pool might have to be established by the federal government, requiring congressional action.

\subsection{PROVISIONS FOR CONTINGENCY COSTS}

This section provides a brief discussion of the issues associated with contingency cost protection for nuclear power plant decommissioning. Contingency costs here do not refer to ordinary cost overruns incurred during decommissioning, which can be handled by building a reasonable contingency factor into the sinking fund payments. Rather, the concern is with unexpected factors, such as corrective action needed for unexpected radionuclide releases or unanticipated requirements caused by changing regulations, or by unanticipated rates of inflation. 
The important issue is who should bear the risk if decommissioning costs exceed available trust funds. This issue should be covered by the nuclear license or by the contract agreement used in setting up the decommissioning fund. In general, however, it is appropriate that the utility bear the overrun, primarily because it benefitted from plant operation and has ultimate responsibility for decommissioning regardless of the existence of a trust fund to cover the decommissioning costs. Moreover, the utility will want to complete decommissioning to mitigate future liability. If a sufficient trust fund is not available, the utility still has decommissioning responsibility, regardless of the cost.

If the utility is financially incapacitated at the time of the decommissioning cost overruns, the burden of these excess costs may fall to the state and/or federal government. This possibility should encourage regulatory agencies to be diligent in licensing and in monitoring nuclear plants to correct operating practices that may aggravate decommissioning problems, as well as to prevent changing regulations that may cause exhorbitant decommissioning cost overruns. 


\section{REFERENCES}

1. 10 CFR 50.33(f), Code of Federal Regulations, "Contents of Applications, General Information."

2. The Uranium Mill Tailings Control Act of 1978 (92 Stat. 3201 ).

3. Plan for Reevaluation of NRC Policy on Decommissioning of Nuclear Nuclear Facilities, NUREG-0436, 43 Federal Register 10370, March 13, 1978.*

4. Robert S. Wood, Assuring the Availability of Funds for Decommissioning Nuclear Facilities, NUREG-0584, draft report issued JuTy 1979.**

5. Internat Revenue Code, Section 115.

6. Ibid, Section $67(a)$.

7. Ibid, Section 162 .

8. Task Force Report on Bonding and Perpetual Care of Licensed Nuclear Activities, Conference of Radiation Control Program Directors, p. 21 , Apri1 1976 .

9. Financial Alternatives for Stabilization, Reclamation, and Long-Term Monitoring and Maintenance of Uranium Mill Tailings Piles, Science Applications, Inc., p. 18, Los Angeles, CA, October 1977.

Available for purchase from the NRC/GPO Sales Program, U.S. Nuclear Regulatory Commission, Washington, D.C. 20555, and the National Technical Information Service, Springfield, Virginia 22161.

** Available for free upon written request from the U.S. Nuclear Regulatory Commission, Division of Technical Information and Document Control, Washington, D.C. 20555. 


\section{CHAPTER 7}

\section{CHARACTERISTICS OF THE REFERENCE BWR POWER STATION}

This chapter contains a brief description of the characteristics of the reference BWR power station, summarizing the detailed information contained in Appendices $B$ through $E$ in Volume 2. Included are descriptions of both the reference site and the reference facility. Also included are estimates of the radiation dose rates and surface contamination levels, the radionuclide inventories, and the chemical inventory at the station at the time of final reactor shutdown. The information presented is typical of large, present-generation, BWR power stations.

\subsection{THE REFERENCE SITE}

A reference site, described briefly in this section, is used in assessing the public safety effects of decommissioning a BWR by various alternative methods. The characteristics of the reference site are representative of existing and potential nuclear reactor sites in the midwestern or middle southeastern United States. The detailed information supporting this abbreviated site description is found in Appendix $B$ in Volume 2, which is developed from information contained in References 1 and 2 .

Individual features of this reference site vary from those of any specific BWR site. However, it is believed that use of a reference site rather than any specific site results in a more meaningful overall analysis of potential impacts associated with decommissioning nuclear power facilities. Site-specific assessments will be required for the safety analysis and the environmental report submitted with the request for license amendment prior to actively decommissioning a specific facility.

The $4.7-\mathrm{km}^{2}$ reference site is a rectangle $2 \mathrm{~km}$ by $2.35 \mathrm{~km}$ in dimension, with a river of moderate site running through one corner. The plant facilities are located inside a $0.12-\mathrm{km}^{2}$ fenced portion of the site. The minimum distance from the point of plant airborne releases to the outer site boundary is $1 \mathrm{~km}$. 
The reference site is located in a rural area with a relatively low population density. About $80 \%$ of the land in the vicinity of the site is farmed. High population densities are located at distances of 10 to $80 \mathrm{~km}$, and gradually reducing population densities are encountered out to $180 \mathrm{~km}$. The closest moderately large city, population 40,000 , is about $30 \mathrm{~km}$ distant. The nearest large city, with 1.8 million inhabitants, is about $50 \mathrm{~km}$ away. The total population in a radius of $80 \mathrm{~km}$ is 3.52 million.

The climate at the site is typical for internal continental areas, with wide temperature variations and moderate precipitation. Meteorology information used in this study is averaged from 16 nuclear reactor sites, with an annual average atmospheric dispersion factor $\left(\bar{X} / Q^{\prime}\right)$ of about $5 \times 10^{-8} \mathrm{sec} / \mathrm{m}^{3}$ at the closest site boundary.

In this study, the reference site is assumed to be slightly contaminated with radioactive material as a result of deposition from normal operating effluents over a 30-EFPY plant operating life. It is further assumed that any accidental release of radioactive material during operation is cleaned up immediately following the event. Estimates of the maximum contamination levels on the reference site at plant shutdown are given in Section 7.4.

\subsection{THE REFERENCE FACILITY}

The reference nuclear power plant in this study is a 3320-MWt' (1155-MWe) boiling water reactor (BWR) being built by the Washington Public Power Supply System (WPPSS). The plant is designated as the WPPSS Nuclear Project No. 2 (WNP-2) and is located near Richland, Washington. It is of the BWR/5 class and the Mark-II containment design, and is expected to start operation in 1982.

The principal plant systems and structures are described briefly in this section. More detailed information is found in Appendix $C$ in Volume 2, which is primarily based on the WPPSS Nuclear Project No. 2 Final Safety Analys is Report. $^{(4)}$

\subsubsection{Nuclear Power Generation System}

The nuclear power generation system of the reference BWR is illustrated in Figure 7.2-1. The principal components and systems of interest are the 


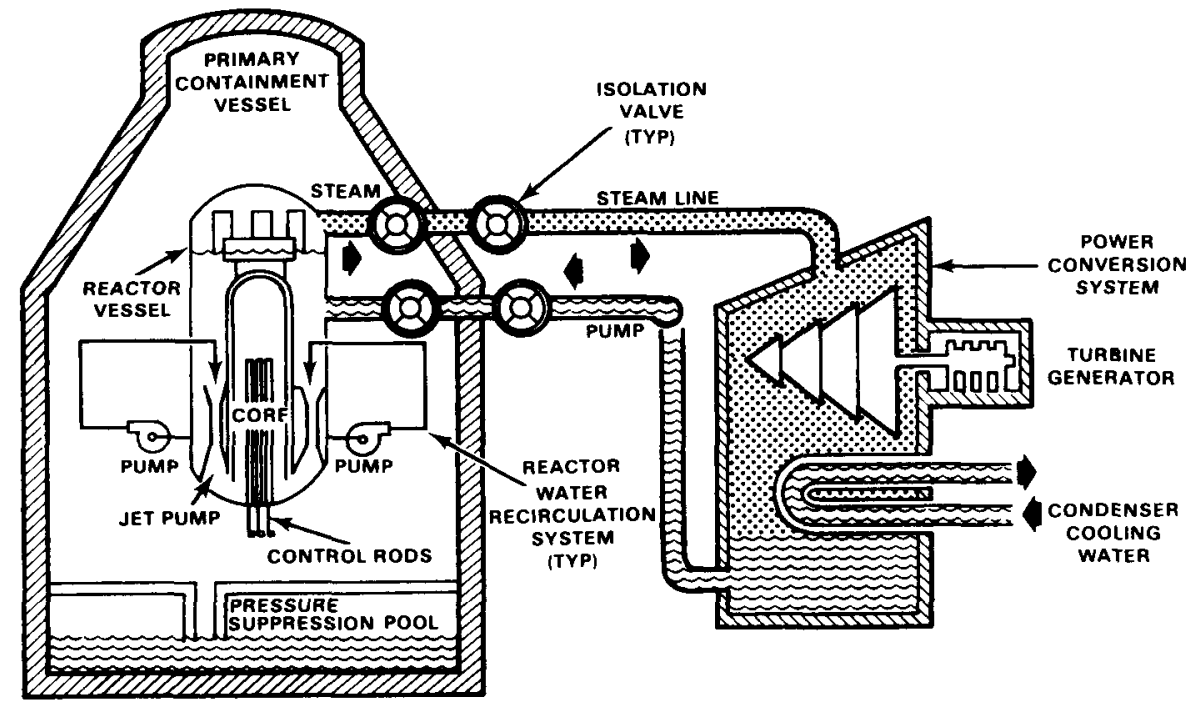

FIGURE 7.2-1. Nuclear Power Generation System

reactor vessel (containing the nuclear core and steam generation equipment), the reactor water recirculation system, and the power conversion system.

\subsubsection{Reactor Vessel and Internals}

The reactor vessel is a right circular cylinder with a permanently attached hemispheric bottom and a removable hemispheric top, as illustrated in Figure 7.2-2. The vessel is made of carbon steel about $0.171 \mathrm{~m}$ thick, with the inside clad with stainless steel about $3 \mathrm{~mm}$ thick. The approximate dimensions of the vessel are $22.2 \mathrm{~m}$ in height and $6.7 \mathrm{~m}$ in outer diameter. The mass of the vessel is nearly $750 \mathrm{Mg}$ empty.

The major reactor internal components are the core (fuel, flow channels, control rods, and instrumentation), the core support structure (including the core shroud, top fuel guide, and core support plate), the shroud head and steam separator assembly, the steam dryer assembly, the jet pumps, the feedwater spargers, and the core spray lines. 


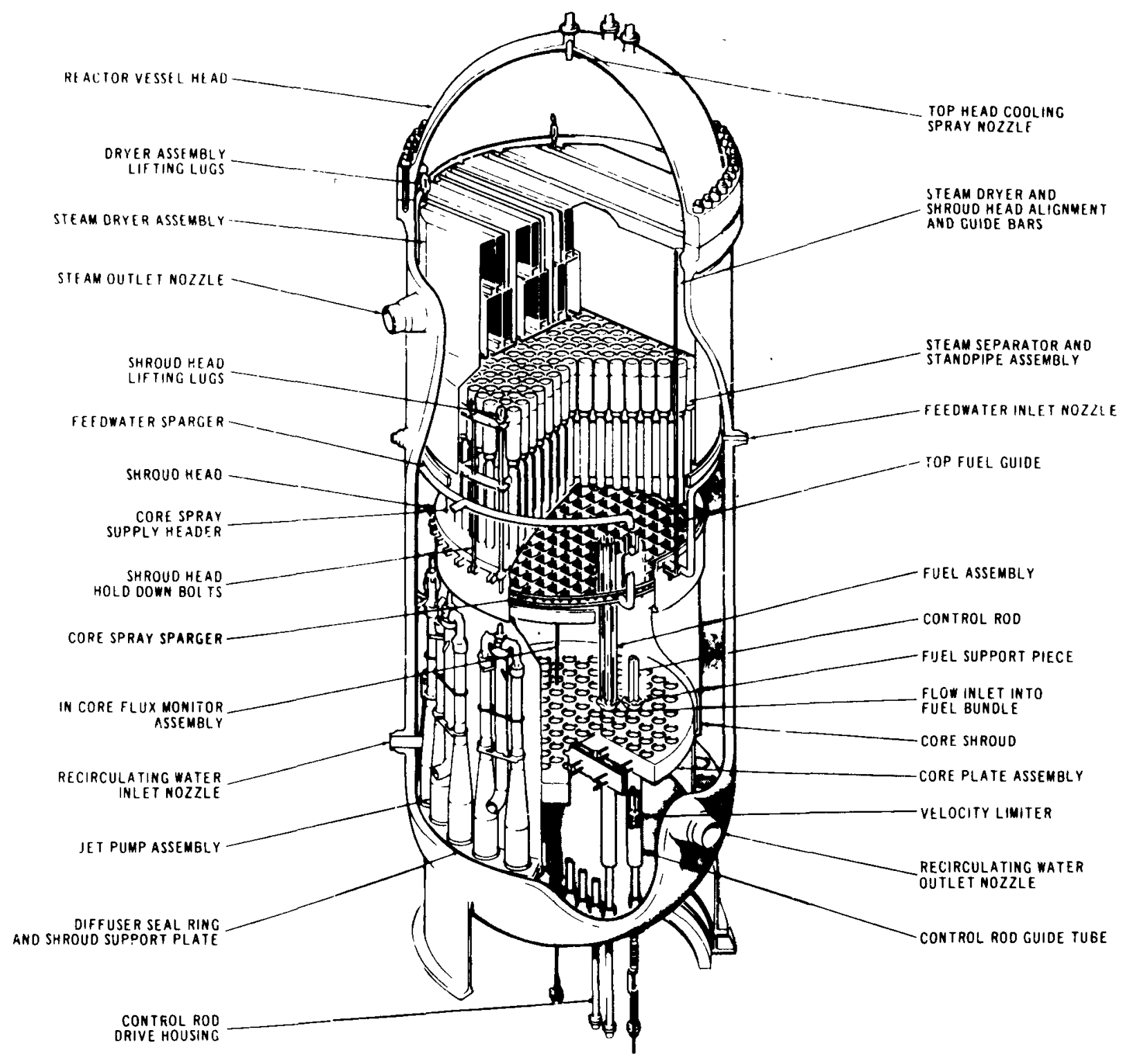

FIGURE 7.2-2. Reactor Vessel and Internals

\subsubsection{Reactor Water Recirculation System}

The reactor water recirculation system, shown in Figure 7.2-3, has two loops external to the reactor vessel but inside the primary containment vessel. Each loop contains a pump, two motor-operated isolation valves, and one hydraulically operated flow-control valve. Each loop supplies reactor 

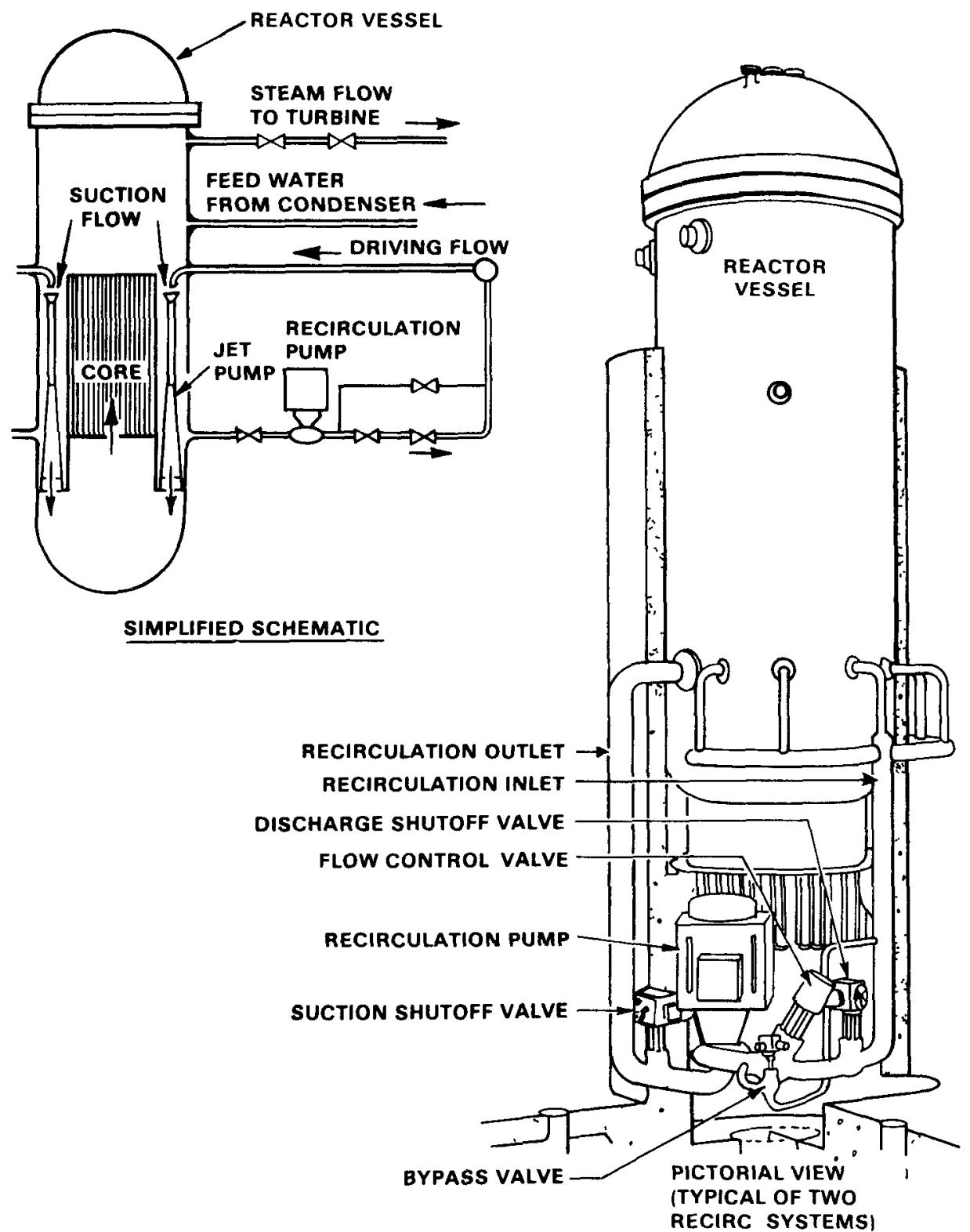

FIGURE 7.2-3. Reactor Water Recirculation system

water to ten jet pumps located inside the reactor vessel in the annular region between the core shroud and the vessel wall (refer to Figure 7.2-2).

\subsubsection{Power Conversion System}

The power conversion system converts the usable energy from the steam produced in the reactor vessel to electricity, condenses the steam, and heats 
the condensate and pumps it back to the reactor as feedwater. The system, shown in Figure 7.2-4, consists of a large steam turbine and generator, moisture separator-reheaters, a single-pass condenser, motor-driven condensate and condensate booster pumps, a full-flow condensate demineralizer system, turbine-driven feedwater pumps, and six stages of feedwater heating.

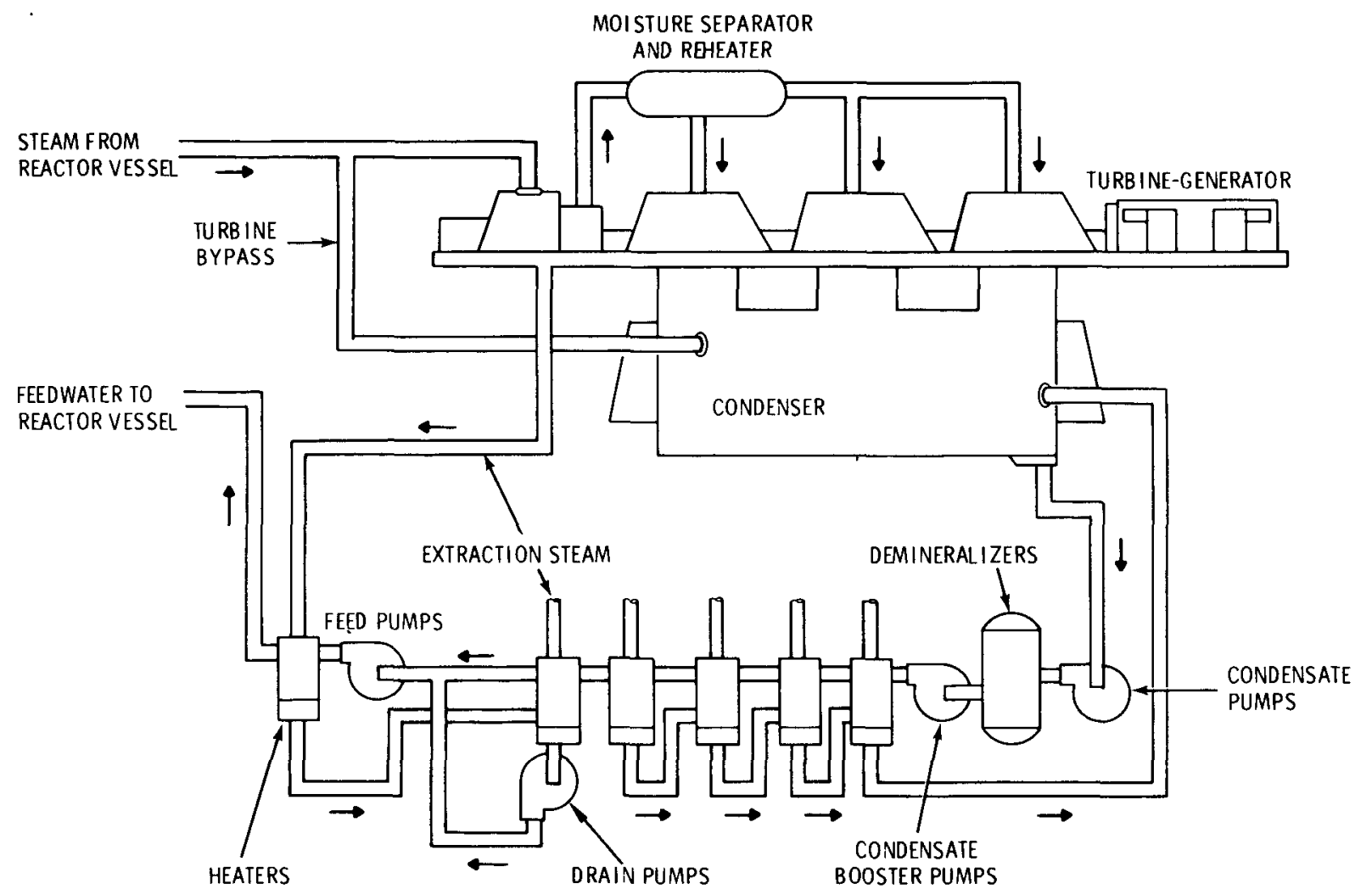

FIGURE 7.2-4. Power Conversion System

\subsubsection{Plant Structures}

The arrangement of the structures on the reference BWR plant site is illustrated in Figure 7.2-5. The structures of primary interest during decommissioning are the Reactor Building, the Turbine Generator Building, and the Radwaste and Control Building. These buildings contain radioactive materials that require special handling during decommissioning. The other structures, if removed, are conventionally demolished. 


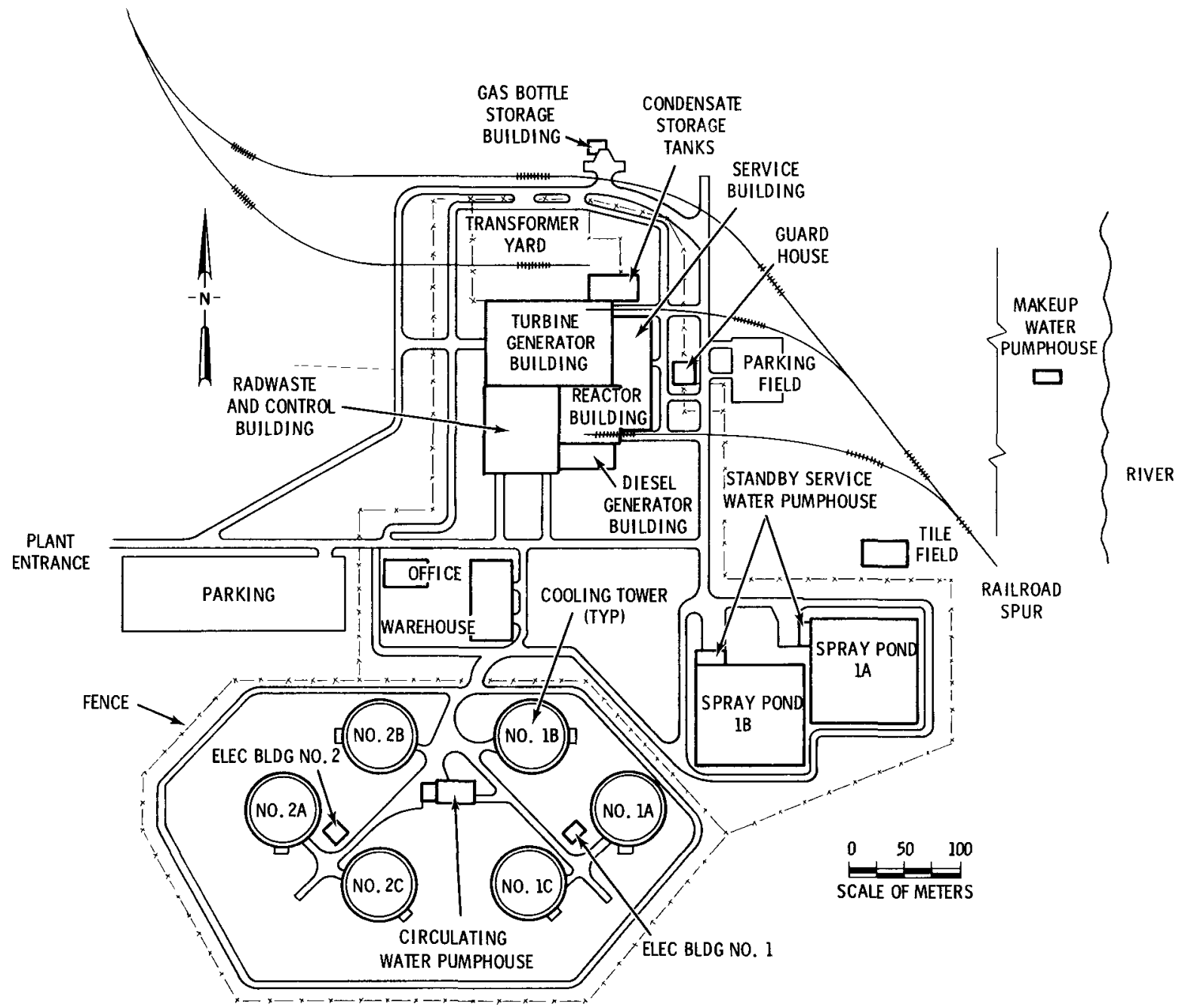

FIGURE 7.2-5. Site Layout of the Reference BWR Power Plant

The buildings in the main complex are in close proximity to each other, but are physically separate from one another both above and below grade.

\subsubsection{Reactor Building}

The Reactor Building, containing the nuclear steam supply system and its auxiliaries, is constructed of reinforced concrete capped by metal siding and roofing supported by structural steel. As shown in Figure 7.2-6, the building surrounds the primary containment vessel, a free-standing steel pressure vessel. The maximum exterior dimensions of the Reactor Building are $41.9 \mathrm{~m}$ by $52.9 \mathrm{~m}$ in plan, $70.2 \mathrm{~m}$ above grade, and $10.6 \mathrm{~m}$ below grade to the bottom of the foundation mat. 


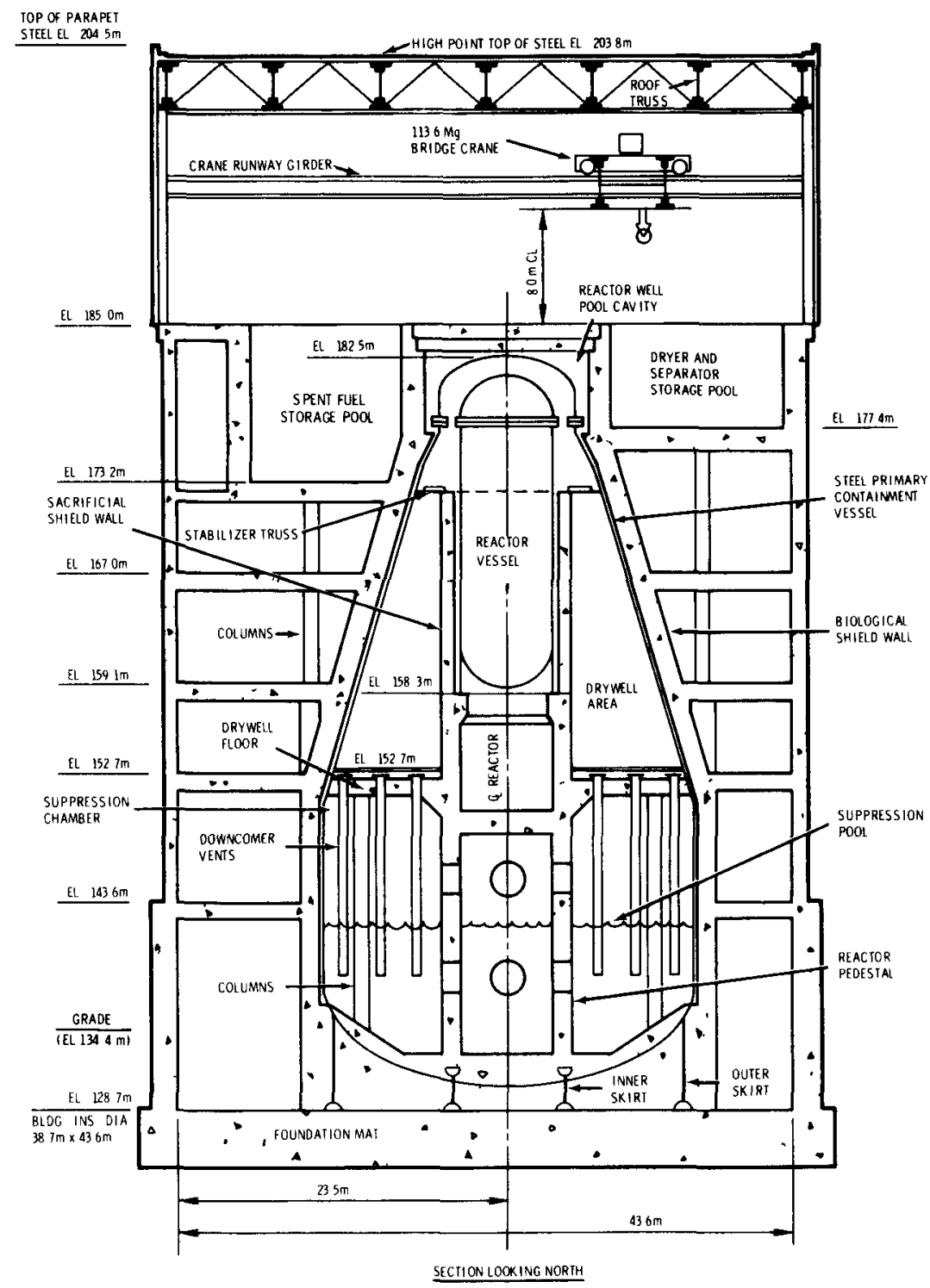

FIGURE 7.2-6. Reactor Building

\subsubsection{Turbine Generator Building}

The Turbine Generator Building contains the power conversion system equipment and auxiliaries. It is constructed of reinforced concrete capped by steel-supported metal siding and roofing, and is approximately $58.8 \mathrm{ri}$ by $91.4 \mathrm{~m}$ in plan and $42.5 \mathrm{~m}$ high. There are two floors above the ground floor. Two 
steel tanks for condensate storage are located within a reinforced concrete dike just outside the building.

\subsubsection{Radwaste and Control Building}

The Radwaste and Control Building houses, among other systems, the condenser off gas treatment system, the radioactive liquid and solid waste systems, the condensate demineralizer system, the reactor water cleanup demineralizer system, and the fuel pool cooling and cleanup demineralizer system. The building is constructed of reinforced concrete and metal-sided and-roofed structural steel, with two full floors and one partial floor above the ground floor. It is approximately $63.7 \mathrm{~m}$ by $48.8 \mathrm{~m}$ in plan and $32 \mathrm{~m}$ in overall height.

\subsubsection{Other Structures}

The remaining buildings of the reference BWR site complex, described briefly here, are assumed in this study to be uncontaminated with radioactive material.

Diesel Generator Building. The Diesel Generator Building contains the emergency-power diesel generators and their associated equipment. It is constructed of reinforced concrete and is approximately $48.5 \mathrm{~m}$ by $24.4 \mathrm{~m}$ in plan and $13.4 \mathrm{~m}$ in height. It has one complete floor above the ground floor, with a partial floor above that.

Service Building. The Service Building houses the main plant administrative offices, the main machine shop, and the makeup water treatment system. It contains two stories above grade and a partial substructure. The building is about $25 \mathrm{~m}$ by $52 \mathrm{~m}$ in plan adjacent to the Turbine Generator Building and about $18 \mathrm{~m}$ by $32 \mathrm{~m}$ adjacent to the Reactor Building, and is approximately $10 \mathrm{~m}$ high above grade with a $6-\mathrm{m}$ substructure. It is constructed of precast concrete above grade and reinforced concrete below grade.

Cooling Tower Complex. The six cooling towers are of the circular, mechanical-draft design. Each has six fans on top, is $18.3 \mathrm{~m}$ high and $61.0 \mathrm{~m}$ in diameter, and is made largely of precast concrete modules on a reinforced concrete basin. 
The Circulating Water Pumphouse is a single-story, steel-framed structure above ground with a reinforced concrete substructure. It is $19 \mathrm{~m}$ by $40 \mathrm{~m}$ in lateral dimension, $12 \mathrm{~m}$ above and $9 \mathrm{~m}$ below grade. The two electrical buildings are single-story, steel-framed buildings, each $12 \mathrm{~m}$ by $15 \mathrm{~m}$ in plan and $5 \mathrm{~m}$ in height.

Spray Pond Complex. The two spray ponds are $73-\mathrm{m}$ by $74-\mathrm{m}$ by $4.6-\mathrm{m}-\mathrm{deep}$ reinforced concrete basins. Each is constructed integrally with a Standby Service Water Pumphouse, which is likewise made of reinforced concrete. Each pumphouse is $9.5 \mathrm{~m}$ by $18.3 \mathrm{~m}$ in $\mathrm{plan}$ and $9.8 \mathrm{~m}$ high, with an 8.5 -m-deep pump chamber below.

Makeup Water Pumphouse. The Makeup Water Pumphouse, constructed of reinforced concrete, is located on the bank of the river that runs through a corner of the site. The building contains a pump pit substructure $6.7 \mathrm{~m}$ square inside in plan and $12.7 \mathrm{~m}$ in depth, with a superstructure approximately $23.5 \mathrm{~m}$ by $11.0 \mathrm{~m}$ inside and $5.2 \mathrm{~m}$ from the operating floor to the top of the roof slab.

Office Building. The Office Building is a structural steel building with insulated metal siding and a concrete slab floor. It is approximately $20 \mathrm{~m}$ by $30 \mathrm{~m}$ in plan and $5 \mathrm{~m}$ high at the roof crown.

Warehouse. The Warehouse is similar to the office building in construction, and is approximately $30 \mathrm{~m}$ by $60 \mathrm{~m}$ in plan and $5 \mathrm{~m}$ high at the roof crown.

Guard House. The Guard House is constructed of reinforced concrete below grade and a precast concrete exterior above grade. The substructure is $7.6 \mathrm{~m}$ by $23 \mathrm{~m}$ in plan and $5 \mathrm{~m}$ deep. The superstructure, approximately $15 \mathrm{~m}$ by $23 \mathrm{~m}$ in plan and $5 \mathrm{~m}$ in height, houses a central surveillance complex surrounded on all sides by reinforced concrete walls and slabs. This interior structure is $7.6 \mathrm{~m}$ by $10.1 \mathrm{~m}$ inside in plan.

Gas Bottle Storage Building. The Gas Bottle Storage Building is a precast concrete structure with a reinforced concrete foundation and floor slab, and is rectangular in plan $(9 \mathrm{~m}$ by $8 \mathrm{~m}$ ) and in elevation ( $4 \mathrm{~m}$ above grade). The floor is approximately $1 \mathrm{~m}$ above grade, at the same height as a 4-m-square concrete loading dock adjoining the building. 


\subsection{RADIATION DOSE RATE AND CONCRETE SURFACE CONTAMINATION DATA}

The radiation dose rate in any specific area affects the planning of decommissioning work with respect to temporary shielding, work sequences, decontamination, and radiation exposure. Once these factors have been studied to determine the most efficient work sequence, it is possible to estimate the radiation exposure time and the resultant occupational dose for each task. It is necessary to limit individual exposures in high radiation areas to allow effective use of personnel in both high and low dose rate areas.

The degree to which concrete surfaces are contaminated determines how much surface requires removal and how much contaminated concrete rubble requires disposal.

This section presents summaries of data presented in Appendix $D$ in Volume 2 concerning radiation dose rates and concrete surface contamination for the reference BWR at final shutdown, except the dose rates from the activated components in and around the reactor vessel which are summarized in Section 7.4.

\subsubsection{Estimated Radiation Dose Rates at Shutdown}

Measured shutdown radiation dose rate data were obtained from seven operational BWRs, three dual-unit plants and one single-unit plant. These plants are Dresden Units 2 and 3 and Quad Cities Units 1 and 2 operated by Commonwealth Edison Company, Peachbottom Units 2 and 3 operated by Philadelphia Electric Company, and Monticello operated by Northern States Power Company. At the time of the measurements, the reactors had operated commercially for from 3 to 8 years. Actual data on the sources of radiation and corresponding dose rates were provided by the health physics personnel at all four sites. Composites are created from these data and are used as radiation dose rates in the reference BWR at final shutdown. Typical samples of the composite radiation dose rates are shown in Table 7.3-1. Detailed lists of these radiation dose rates are contained in Figures D.1-1 through D.1-7 in Appendix D.

\subsubsection{Estimated Concrete Surface Contamination Levels at Shutdown}

Measured concrete surface contamination level data were obtained from the same four operational BWR sites as were the dose rate data. Typical samples of 
TABLE 7.3-1. Typical Radiation Dose Rates in the Reference BWR at Shutdown(a)

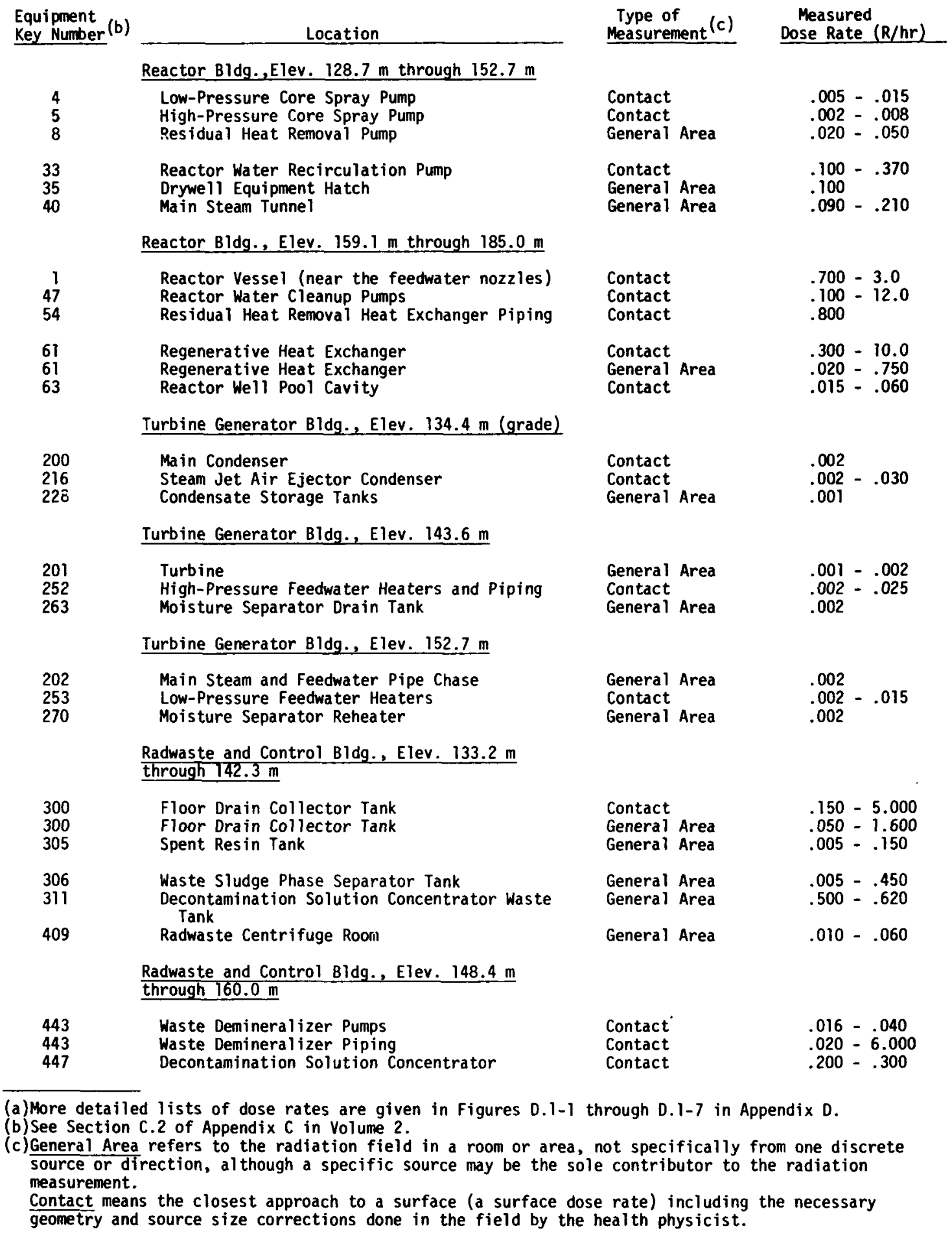


composites of these data are 1isted in Table 7.3-2 (see next page). More detailed lists of measured concrete surface contamination data are provided in Figures D.2-1 through D.2-7 in Appendix $D$.

\subsubsection{Contaminated Concrete Rubble Volumes Removed During \\ Immediate Dismantlement}

The volumes of contaminated concrete rubble estimated removed during immediate dismantlement of the reference BWR are summarized in Table 7.3-3 for the Reactor Building (outside Primary Containment), the Primary Containment, the Turbine Generator Building, and the Radwaste and Control Building. The maximum measured contamination level in each location is also displayed. These quantities are derived from data given in Figures D.2-1 through D.2-7.

TABLE 7.3-3. Contaminated Concrete Rubble Volumes Removed During Immediate Dismantlement of the, Reference BWR(a)

\begin{tabular}{|c|c|c|}
\hline Building (b) & $\begin{array}{c}\text { Maximum Measured } \\
\text { Contamination Leve1s }(\mathrm{c}) \\
(\mathrm{cpm} / 100 \mathrm{~cm} 2) \\
\end{array}$ & $\begin{array}{c}\text { Estimated Tota } \\
\text { Rubble Volumes }(d) \\
\left(\mathrm{m}^{3}\right)\end{array}$ \\
\hline Reactor Building (e) & $>500 k(f)$ & 204.5 \\
\hline Primary Containment & $2000 k$ & 155.8 \\
\hline Turbine Generator Building & $100 \mathrm{k}$ & 105.8 \\
\hline Radwaste and Control Building & $300 \mathrm{k}$ & 203.4 \\
\hline
\end{tabular}

(a)More detailed lists of contaminated concrete rubble volumes are provided in Figures $0.2-1$ through $0.2-7$ in Appendix $D$.

(b) other buildings and facilities on the reference BWR site are assumed to have no contamination.

(c) Measurements taken during maintenance outages at operating BWRs.

(d) Based on a contamination thickness of $0.051 \mathrm{~m}$.

(e) Includes all areas of the Reactor Ruilding except inside Primary Containment. (f) $500 \mathrm{k}$ stands for $500,000 \mathrm{cpm} / 100 \mathrm{~cm}^{2}$ (typical).

\subsection{RADIONUCLIDE INVENTORIES}

The radionuclide inventories at the time of final reactor shutdown (excluding the irradiated spent fuel) are of two types: 1) neutron-activated components in and surrounding the reactor core, and 2) surface contamination from fission products and activated corrosion products deposited inside certain 


\section{TABLE 7.3-2. Typical Measured Concrete Surface Contamination Levels in the Reference BWR at Shutdown(a)}

Associated

Equipment

Key Number (b)

2,3
33
34
35
40
${ }_{N A}(e)$

46

47

61,62

200

214

218

252

253

258

201

270

302

360

379

407

408

432

433

NA
Location

Reactor B7dg., Elev. $128.7 \mathrm{ml}$ through $152.7 \mathrm{~m}$

Suppression Chamber

Reactor Water Recirculation Pump Area (Drywell Floor)

Drywell Personnel Lock Room

Drywell Equipment Hatch Room

Main Steam Tunnel

CRD Repair Room, Elev. $152.7 \mathrm{~m}$

Measured

Contamination

Level (c)

$\left(\mathrm{cpm} / 100 \mathrm{~cm}^{2}\right)$

Reactor B1dg., Elev. $159.1 \mathrm{~m}$ through $185.0 \mathrm{~m}$

Control Rod Drive Module Areas

Reactor Water Cleanup Pump Rooms

Reactor Water Cleanup Regenerative

and Non-Regenerative HX Room

$0.3-2.5 k^{(d)}$

2-2000k

$0.2-30 k$

$0.4-2 k$

$0.1-12.5 k$

$0.6-35 k$

Turbine Generator B1dg., Elev. 134.4 (grade)

Main Condenser Area

Reactor Feedwater Pump Rooms

Catalytic Recombiner Room

$0.2-2.5 k$

$0.5-9$

$0.2-20 k$

Turbine Generator B7dg., Elev. $143.6 \mathrm{~m}$

High-Pressure Feedwater Heater Area

Low-Pressure Feedwater Heater Area

Turbine By-Pass Valve Assembly Area

$0.2 \mathrm{k}$

$0.2-2.1 k$

$30-100 k$

Turbine Generator Bldg., Elev. $152.7 \mathrm{~m}$

Turbine Area

Moisture Separator Reheater Area

$0.1-0.4 k$

$0.1+1.0 k$

Radwaste and Control Bldg., Elev. $133.2 \mathrm{~m}$ through 142.3 m

Condensate Phase Separator Tank Area

$0.5-150 k$

$0.6-90 k$

Sol id Radwaste Hopper Mixer Room

$0.2-6.2 k$

quipment Removal Plugs and Filter

Demineralizer Removal Room (Elev. $154.5 \mathrm{~m}$ )

Concentrator Waste Measuring Tank Room

Cleanup Hold Pump Areas, Valve and Pump Rooms

$80 \mathrm{k}$

$2.8-10 k$

Fuel Poot Hold Pump Rooms

Hot Machine Shop (Elev. $148.4 \mathrm{~m}$ )
$2.5-200 k$

$<0.1 k$

(a) Hore detailed lists of measured concrete surface contamination data are provided in Figures $D .2-1$ through $D .2-7$ in Appendix $D$.

(b) Numbers used in Figures $D .2-7$ through $0.2-7$ to identify the location of concrete surface contamination.

(c) Composite of measurements taken during maintenance outages at operating BWRs.

(d) $0.3-2.5 \mathrm{k}$ stands for 300 to $2,500 \mathrm{cpm} / 100 \mathrm{~cm}^{2}$ (typical).

(e) Indicates "not available." 
piping and equipment systems, on some structural surfaces, and on the site. This section presents a summary of the information contained in Appendix $E$ in Volume 2 .

Details of the calculational methods used for estimating the radionuclide inventories at the reference BWR are presented in Appendix $E$. It should be recognized that the radionuclide inventories are calculated based on current operational data applied to the reference plant, and are not directly applicable to any specific operating BWR. Prior to decommissioning a BWR, site-specific measurements of the mixtures and levels of radionuclides present are required.

A total of six reference radionuclide inventories are characterized for this study. These inventories are used to help estimate the total radioactivity present at the site, the disposal requirements and costs, and the impact of decommissioning operations on public safety. They are also used to demonstrate the suggested methodology for determining acceptable residual radioactive contamination levels.

\subsubsection{Neutron-Activated Components}

Radioactive material is produced in the structural components in and around the reactor vessel because of interactions with neutrons produced in the reactor fuel during operation. Three basic types of materials are used in and around the reactor vessel: stainless steel (type 304), carbon steel (type SA 533), and reinforced concrete. This subsection contains summaries of the radionuclide inventories for, the total radioactivity in, and selected dose rates for the neutron-activated components.

\subsubsection{Radionuclide Inventories in Neutron-Activated Materials}

The radionuclide inventories calculated for the neutron-activated materials at final reactor shutdown are presented as follows: Table 7.4-1 for stainless steel (reference radionuclide inventory 1), Table 7.4-2 for carbon steel (reference radionuclide inventory 2), and Table 7.4-3 for reinforced concrete (reference radionuclide inventory 3 ). Reference radionuclide inventory 3 accounts for the radionuclides both in the concrete and in the carbon-steel reinforcing material in the sacrificial shield. 


\section{TABLE 7.4-1.
Reference Radionuclide Inventory
Neutron-Activated Stainless Steel (ả)}

\begin{tabular}{|c|c|c|}
\hline Radionuclide & $\begin{array}{c}\text { Radioactivity } \\
\text { Concentration } \\
\text { at Shutdown } \\
\left(\mathrm{Ci} / \mathrm{m}^{3}\right) \\
\end{array}$ & $\begin{array}{l}\text { Fractional } \\
\text { Radioactivity } \\
\text { at Shutdown }\end{array}$ \\
\hline $\begin{array}{l}{ }_{10}^{3} \mathrm{H} \\
1{ }^{14} \mathrm{Be}\end{array}$ & $\begin{array}{l}4.65 \times 10^{-4} \\
2.63 \times 10^{-6} \\
1.05 \times 10^{2}\end{array}$ & $\begin{array}{c}1.63 \times 10^{-10} \\
3.68 \times 10^{-5}\end{array}$ \\
\hline $\begin{array}{l}32 p p \\
33 p p \\
35\end{array}$ & $\begin{array}{l}1.11 \times 10^{2} \\
6.65 \times 10^{2} \\
5.52 \times 10^{1}\end{array}$ & $\begin{array}{l}3.89 \times 10^{-5} \\
2.33 \times 10^{-4} \\
1.94 \times 10^{-5}\end{array}$ \\
\hline $\begin{array}{l}36 \mathrm{Cl} \\
51 \mathrm{Cl} \\
54 \mathrm{Mn}\end{array}$ & $\begin{array}{l}2.69 \times 10^{-4} \\
1.45 \times 10^{6} \\
8.50 \times 10^{3}\end{array}$ & $\begin{array}{l}5.09 \times 10^{-1} \\
2.98 \times 10^{-3}\end{array}$ \\
\hline $\begin{array}{l}55 \\
59 \mathrm{Fe} \\
58 \mathrm{Fe} \\
{ }^{\mathrm{Co}}\end{array}$ & $\begin{array}{l}9.22 \times 10^{5} \\
2.74 \times 10^{4} \\
2.10 \times 10^{4}\end{array}$ & $\begin{array}{l}3.24 \times 10^{-1} \\
9.61 \times 10^{-3} \\
7.37 \times 10^{-3}\end{array}$ \\
\hline $\begin{array}{l}60 \\
59 \mathrm{Co} \\
53_{\mathrm{Ni}}\end{array}$ & $\begin{array}{l}3.36 \times 10^{5} \\
6.36 \times 10^{2} \\
8.75 \times 10^{4}\end{array}$ & $\begin{array}{l}1.18 \times 10^{-1} \\
2.23 \times 10^{-4} \\
3.07 \times 10^{-2}\end{array}$ \\
\hline $\begin{array}{l}65 \mathrm{Zn} \\
93 \mathrm{Zn} \\
95_{\mathrm{Zr}}\end{array}$ & $\begin{array}{l}3.23 \times 10^{1} \\
8.15 \times 10^{-6} \\
1.41 \times 10^{-2}\end{array}$ & $\begin{array}{r}1.13 \times 10^{-5} \\
4.21 \times 10^{-5}\end{array}$ \\
\hline $\begin{array}{r}93 \mathrm{~m}_{\mathrm{Nb}} \\
94_{\mathrm{Nb}} \\
95_{\mathrm{Nb}}\end{array}$ & $\begin{array}{l}1.35 \times 10^{-1} \\
1.50 \times 10^{0} \\
1.20 \times 10^{2}\end{array}$ & $\begin{array}{l}4.74 \times 10^{-8} \\
5.26 \times 10^{-7} \\
4.21 \times 10^{-5}\end{array}$ \\
\hline $\begin{array}{r}93_{\mathrm{Mo}} \\
99_{\mathrm{Tc}} \\
108 \mathrm{~m}_{\mathrm{Ag}}\end{array}$ & $\begin{array}{l}3.26 \times 10^{-1} \\
3.18 \times 10^{-2} \\
7.36 \times 10^{-2}\end{array}$ & $\begin{array}{l}1.14 \times 10^{-7} \\
1.12 \times 10^{-8} \\
2.58 \times 10^{-8}\end{array}$ \\
\hline $\begin{array}{r}108 \\
{ }^{109 m_{A g}} \\
109^{\mathrm{Cd}}\end{array}$ & $\begin{array}{l}8.67 \times 10^{1} \\
3.61 \times 10^{0} \\
3.42 \times 10^{0}\end{array}$ & $\begin{array}{l}3.04 \times 10^{-5} \\
1.27 \times 10^{-6} \\
1.20 \times 10^{-6}\end{array}$ \\
\hline $\begin{array}{l}110 \mathrm{~m} \\
110^{\mathrm{Ag}} \\
151 \mathrm{Ag} \\
15 \mathrm{Sm}\end{array}$ & $\begin{array}{l}8.04 \times 10^{0} \\
2.02 \times 10^{2} \\
2.12 \times 10^{-2}\end{array}$ & $\begin{array}{l}2.82 \times 10^{-6} \\
7.09 \times 10^{-5} \\
7.44 \times 10^{-9}\end{array}$ \\
\hline $\begin{array}{r}152 \\
154 \mathrm{Eu} \\
160 \mathrm{Eu} \\
166 \mathrm{~m}_{\mathrm{Ho}} \\
\end{array}$ & $\begin{array}{l}1.12 \times 10^{-3} \\
3.12 \times 10^{-4} \\
9.48 \times 10^{-4} \\
7.84 \times 10^{-4} \\
\end{array}$ & $\begin{array}{l}3.93 \times 10^{-10} \\
1.09 \times 10^{-6} \\
3.33 \times 10^{-10} \\
2.75 \times 10^{-10} \\
\end{array}$ \\
\hline Totals & $2.85 \times 10^{6}$ & 1.00 \\
\hline
\end{tabular}

(a)Calculated at the inner surface of the 304 stainless steel core shroud, at the axial midplane of the fuel zone, for 30 EFPY of operation; these data are a summary of the data presented in

Table E.1-l in Appendix E.
(b) Indicates a value of less than $1.00 \times 10^{-10}$. 
TABLE 7.4-2. Reference Radionuclide Inventory 2, Neutron-Activated Carbon Steel(a)

\begin{tabular}{|c|c|c|}
\hline Radionuclide & $\begin{array}{c}\text { Radioactivity } \\
\text { Concentration } \\
\text { at Shutdown } \\
\left(\mathrm{Ci} / \mathrm{m}^{3}\right) \\
\end{array}$ & $\begin{array}{l}\text { Fractional } \\
\text { Radioactivity } \\
\text { at Shutdown }\end{array}$ \\
\hline $\begin{array}{l}{ }^{14} \mathrm{C} \\
{ }_{32}^{\mathrm{C}} \mathrm{P} \\
{ }_{\mathrm{S}}\end{array}$ & $\begin{array}{l}6.77 \times 10^{-3} \\
9.20 \times 10^{-1} \\
1.76 \times 10^{-2}\end{array}$ & $\begin{array}{l}1.84 \times 10^{-5} \\
2.51 \times 10^{-3} \\
4.80 \times 10^{-5}\end{array}$ \\
\hline $\begin{array}{l}51 \\
54 \mathrm{Cr} \\
55_{\mathrm{Fe}}^{\mathrm{Mn}}\end{array}$ & $\begin{array}{l}1.75 \times 10^{0} \\
1.06 \times 10^{2} \\
3.35 \times 10^{2}\end{array}$ & $\begin{array}{l}4.77 \times 10^{-3} \\
2.89 \times 10^{-2} \\
9.13 \times 10^{-1}\end{array}$ \\
\hline $\begin{array}{l}59 \\
58 \mathrm{Fe} \\
60 \mathrm{Co} \\
{ }_{\mathrm{Co}}\end{array}$ & $\begin{array}{l}9.44 \times 10^{0} \\
1.49 \times 10^{0} \\
6.49 \times 10^{0}\end{array}$ & $\begin{array}{l}2.57 \times 10^{-2} \\
4.06 \times 10^{-3} \\
1.77 \times 10^{-2}\end{array}$ \\
\hline $\begin{array}{l}59 \\
63^{\mathrm{Ni}} \\
655_{\mathrm{Zn}}\end{array}$ & $\begin{array}{l}1.46 \times 10^{-2} \\
1.73 \times 10^{0} \\
1.88 \times 10^{-6}\end{array}$ & $\begin{array}{l}3.98 \times 10^{-5} \\
4.71 \times 10^{-3} \\
5.12 \times 10^{-9}\end{array}$ \\
\hline $\begin{array}{l}98 \mathrm{Sr} \\
91 \mathrm{Sr} \\
95 \mathrm{Zr}\end{array}$ & $\begin{array}{l}5.24 \times 10^{-13} \\
2.25 \times 10^{-13} \\
1.62 \times 10^{-4}\end{array}$ & $\begin{array}{l}1.43 \times 10^{-15} \\
6.13 \times 10^{-16} \\
4.41 \times 10^{-7}\end{array}$ \\
\hline $\begin{array}{l}93 \mathrm{~m}_{\mathrm{Nb}} \\
94 \mathrm{Nb} \\
95 \mathrm{Nb}\end{array}$ & $\begin{array}{l}3.90 \times 10^{-4} \\
8.30 \times 10^{-7} \\
3.76 \times 10^{-4}\end{array}$ & $\begin{array}{l}1.06 \times 10^{-6} \\
2.26 \times 10^{-9} \\
1.02 \times 10^{-6}\end{array}$ \\
\hline $\begin{array}{l}93 \\
99 \\
9 \mathrm{Mc}\end{array}$ & $\begin{array}{l}9.39 \times 10^{-4} \\
2.64 \times 10^{-4} \\
\end{array}$ & $\begin{array}{l}2.56 \times 10^{-6} \\
7.19 \times 10^{-7} \\
\end{array}$ \\
\hline Totals & $3.67 \times 10^{2}$ & 1.00 \\
\hline
\end{tabular}

(a)Calculated at the inner surface of the SA 533 carbon steel reactor vessel, at the axial midplane of the fuel zone, for 30 EFPY of operation; these data are a summary of the data presented in Table E.1-2 in Appendix E. 
TABLE 7.4-3. Reference Radionuclide Invenfory 3, Neutron-Activated Concrete(a)

\begin{tabular}{|c|c|c|}
\hline Radionucl ide & $\begin{array}{l}\text { Radioactivity } \\
\text { Concentration } \\
\text { at Shutdown } \\
\left(\mathrm{Ci} / \mathrm{m}^{3}\right) \\
\end{array}$ & $\begin{array}{l}\text { Fractional } \\
\text { Radioactivity } \\
\text { at Shutdown }\end{array}$ \\
\hline $\begin{array}{l}{ }_{14}^{3} \mathrm{H} \\
32_{\mathrm{P}}^{\mathrm{C}}\end{array}$ & $\begin{array}{l}2.58 \times 10^{-6} \\
1.36 \times 10^{-4} \\
4.35 \times 10^{-2}\end{array}$ & $\begin{array}{l}6.72 \times 10^{-7} \\
3.54 \times 10^{-5} \\
1.13 \times 10^{-2}\end{array}$ \\
\hline $\begin{array}{l}{ }^{35} \mathrm{~S} \\
36 \\
37 \mathrm{Cl}\end{array}$ & $\begin{array}{l}3.25 \times 10^{-3} \\
1.21 \times 10^{-6} \\
3.08 \times 10^{-2}\end{array}$ & $\begin{array}{l}8.46 \times 10^{-4} \\
3.15 \times 10^{-7} \\
8.02 \times 10^{-3}\end{array}$ \\
\hline $\begin{array}{l}39 \\
40^{\mathrm{Ar}} \\
41_{\mathrm{K}} \\
\mathrm{Ca}\end{array}$ & $\begin{array}{l}5.69 \times 10^{-3} \\
3.67 \times 10^{-5} \\
7.90 \times 10^{-4}\end{array}$ & $\begin{array}{l}1.48 \times 10^{-3} \\
9.55 \times 10^{-6} \\
2.06 \times 10^{-4}\end{array}$ \\
\hline $\begin{array}{l}{ }^{45} 6_{\mathrm{Ca}} \\
\left.{ }^{5}\right]_{\mathrm{Cr}}(\mathrm{b})\end{array}$ & $\begin{array}{l}3.91 \times 10^{-1} \\
2.10 \times 10^{-6} \\
1.11 \times 10^{-2}\end{array}$ & $\begin{array}{l}1.02 \times 10^{-1} \\
5.47 \times 10^{-7} \\
2.89 \times 10^{-3}\end{array}$ \\
\hline $\begin{array}{l}54 \mathrm{Mn}^{(\mathrm{b})} \\
55^{\mathrm{Fe}}(\mathrm{b}) \\
59_{\mathrm{Fe}} \mathrm{Fb}^{(\mathrm{b})}\end{array}$ & $\begin{array}{l}9.60 \times 10^{-3} \\
3.15 \times 10^{-1} \\
1.01 \times 10^{-1}\end{array}$ & $\begin{array}{l}2.50 \times 10^{-3} \\
8.20 \times 10^{-1} \\
2.63 \times 10^{-2}\end{array}$ \\
\hline $\begin{array}{l}58 \mathrm{Co}^{(\mathrm{b})} \\
60 \mathrm{Cb} \\
59_{\mathrm{Ni}} \mathrm{Co}^{(\mathrm{b})}\end{array}$ & $\begin{array}{l}3.00 \times 10^{-3} \\
6.45 \times 10^{-2} \\
1.24 \times 10^{-4}\end{array}$ & $\begin{array}{l}7.81 \times 10^{-4} \\
1.68 \times 10^{-2} \\
3.23 \times 10^{-5}\end{array}$ \\
\hline $\begin{array}{l}63_{\mathrm{Ni}}(\mathrm{b}) \\
93 \mathrm{~m}^{\mathrm{Nb}} \\
93_{\mathrm{Mo}}\end{array}$ & $\begin{array}{l}1.47 \times 10^{-2} \\
3.05 \times 10^{-6} \\
7.36 \times 10^{-6}\end{array}$ & $\begin{array}{l}3.83 \times 10^{-3} \\
7.94 \times 10^{-7} \\
1.92 \times 10^{-6}\end{array}$ \\
\hline $\begin{array}{r}99 \\
108 \mathrm{Tc} \\
108 \mathrm{Ag} \\
108 \mathrm{Ag}\end{array}$ & $\begin{array}{l}4.08 \times 10^{-6} \\
9.73 \times 10^{-8} \\
1.24 \times 10^{-4}\end{array}$ & $\begin{array}{l}1.06 \times 10^{-6} \\
2.53 \times 10^{-8} \\
3.23 \times 10^{-5}\end{array}$ \\
\hline $\begin{array}{r}109 \mathrm{~m}_{\mathrm{Ag}} \\
109_{\mathrm{Cg}} \\
110 \mathrm{~m}_{\mathrm{Ag}}\end{array}$ & $\begin{array}{l}2.56 \times 10^{-10} \\
2.17 \times 10^{-10} \\
6.83 \times 10^{-5}\end{array}$ & $\begin{array}{l}6.67 \times 10^{-11} \\
5.65 \times 10^{-11} \\
1.78 \times 10^{-5}\end{array}$ \\
\hline $\begin{array}{l}110 \\
151^{\mathrm{Ag}} \\
152 \mathrm{Sm} \\
\mathrm{Eu}\end{array}$ & $\begin{array}{l}1.74 \times 10^{-3} \\
1.30 \times 10^{-3} \\
1.00 \times 10^{-2}\end{array}$ & $\begin{array}{l}4.53 \times 10^{-4} \\
3.39 \times 10^{-4} \\
2.60 \times 10^{-3}\end{array}$ \\
\hline $\begin{array}{r}154 \\
166 \mathrm{~m}_{\mathrm{Ho}} \\
\end{array}$ & $\begin{array}{l}1.31 \times 10^{-3} \\
3.91 \times 10^{0} \\
\end{array}$ & $\begin{array}{l}3.41 \times 10^{-4} \\
1.02 \times 10^{-6} \\
\end{array}$ \\
\hline Totals & $3.84 \times 10^{0}$ & 1.00 \\
\hline
\end{tabular}

(a) Calculated at the inner surface of the concrete portion of the sacrificial shield, at the axial midplane of the fuel zone, for 30 EFPY of operation; these data are a summary of the data in Table E.1-3 in Appendix $E$.

(b) Due largely to structural steel in the sacrificial shield. 
These inventories are calculated using the thermal neutrons flux distribution at the axial midplane of the fuel zone for 30 EFPY of operation. They are designed to represent maximum values of the neutron-induced radioactivity present at the reference BWR at final shutdown. Thus, the radioactivity concentrations listed in Tables 7.4-1 through 7.4-3 are the maximum concentrations used in this study.

The calculated buildups of selected radionuclides in the core shroud are illustrated in Figure 7.4-1, with the concentration of each radionuclide normalized to unity at $30 \mathrm{EFPY}$. As might be expected, the shorter-lived radionuclides, such as ${ }^{55} \mathrm{Fe}$ and ${ }^{60} \mathrm{Co}$, reach an equilibrium concentration after about 23 years, while the concentrations of the long-lived radionuclides, such as ${ }^{59} \mathrm{Ni}$ and ${ }^{94} \mathrm{Nb}$, increase almost linearly with increased irradiation time.

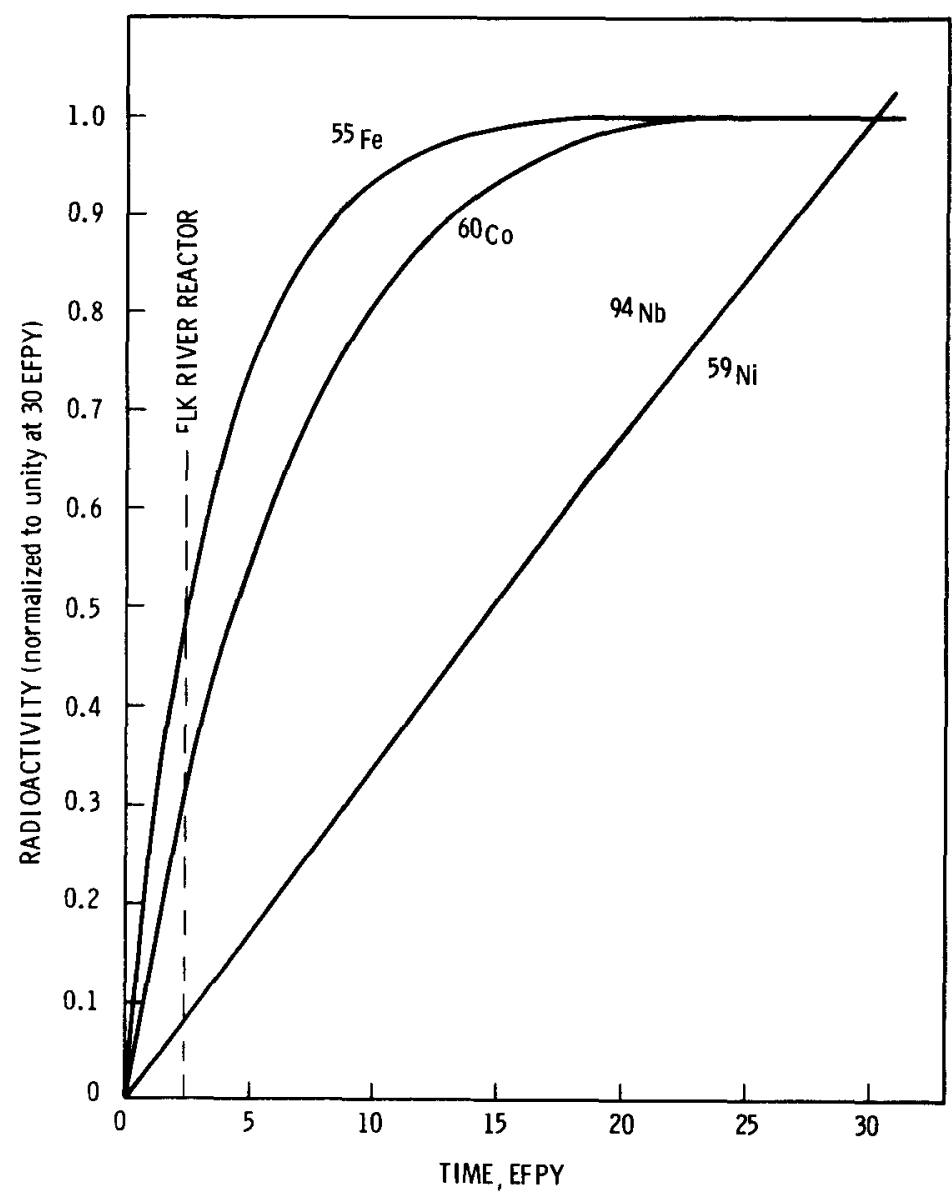

FIGURE 7.4-1. Calculated Buildup of Selected Activation Products in the Core Shroud as a Function of Time at Full Power 
For perspective, the Elk River Reactor had operated for about 2.5 EFPY when it was dismantled. Based on the calculations for this study, the levels of the long-lived radionuclides at Elk River were less than $10 \%$ of those that will be present in the reference BWR after $30 \mathrm{EFPY}$. The shorter-lived radionuclides, $1 \mathrm{ike}{ }^{55} \mathrm{Fe}$ and ${ }^{60} \mathrm{Co}$, probably reached $50 \%$ or less of their 30 -EFPY values at Elk River.

\subsubsection{Total Radioactivity in Neutron-Activated Components}

The total radioactivity in neutron-activated components is summarized in Table 7.4-4. Radioactivity totals in the reactor vessel and its internal components range from about $0.5 \mathrm{Ci}$ in a single control rod guide tube to about 6.3 million $\mathrm{Ci}$ in the core shroud. The sacrificial shield is calculated to

\section{TABLE 7.4-4. Estimated Total Radioactivity in}

\section{Neutron-Activated Components(a)}

\begin{tabular}{|c|c|c|c|}
\hline Component (quantity) & $\begin{array}{l}\text { Estimated } \\
\text { Activated } \\
\text { Volume }\left(\mathrm{m}^{3}\right) \\
\end{array}$ & $\begin{array}{l}\text { Radioactivity per } \\
\text { Component (Ci) } \\
\end{array}$ & $\begin{array}{r}\text { Estimated Total } \\
\text { Radioactivity (Ci) }\end{array}$ \\
\hline $\begin{array}{l}\text { Core Shroud (1) } \\
\text { Jet Pump Assembly (10) }\end{array}$ & $\begin{array}{l}3.75 \\
0.076\end{array}$ & $\begin{array}{l}6.30 \times 10^{6} \\
2.00 \times 10^{3}\end{array}$ & $\begin{array}{l}6.30 \times 10^{6} \\
2.00 \times 10^{4}\end{array}$ \\
\hline $\begin{array}{l}\text { Reactor Vessel (1) } \\
\text { Cladding } \\
\text { Shell Wall }\end{array}$ & $\begin{array}{l}0.428 \\
15.26\end{array}$ & $\begin{array}{l}4.58 \times 10^{2} \\
1.70 \times 10^{3}\end{array}$ & $2.16 \times 10^{3}$ \\
\hline $\begin{array}{l}\text { Sacrificial Shield (1) } \\
\text { Inner Shell } \\
\text { Reinforced Concrete Region } \\
\text { Outer Shell }\end{array}$ & $\begin{array}{r}2.19 \\
73.30 \\
6.22\end{array}$ & $\begin{array}{l}1.03 \times 10^{2} \\
3.47 \times 10^{1} \\
5.39 \times 10^{1}\end{array}$ & $1.66 \times 10^{2}$ \\
\hline $\begin{array}{l}\text { Steam Separator Assembly (1) } \\
\text { Shroud Head Plate } \\
\text { Steam Separator Risers }\end{array}$ & $\begin{array}{l}0.841 \\
0.376\end{array}$ & $\begin{array}{l}8.65 \times 10^{3} \\
9.52 \times 10^{2}\end{array}$ & $9.60 \times 10^{3}$ \\
\hline $\begin{array}{l}\text { Top Fuel Guide (1) } \\
\text { Orificed Fuel Support (193) } \\
\text { Core Support Plate (1) }\end{array}$ & $\begin{array}{l}0.310 \\
0.0036 \\
2.54\end{array}$ & $\begin{array}{l}3.01 \times 10^{4} \\
3.63 \times 10^{2} \\
6.50 \times 10^{2}\end{array}$ & $\begin{array}{l}3.01 \times 10^{4} \\
7.01 \times 10^{2} \\
6.50 \times 10^{2}\end{array}$ \\
\hline $\begin{array}{l}\text { Incore Instrument Strings (55) } \\
\text { Control Rod (185) } \\
\text { Control Rod Guide Tube (185) } \\
\text { Total }\end{array}$ & $\begin{array}{l}0.00026 \\
0.0019 \\
0.0024\end{array}$ & $\begin{array}{l}1.99 \times 10^{2} \\
9.61 \times 10^{2} \\
5.12 \times 10^{-1}\end{array}$ & $\begin{array}{l}1.10 \times 10^{4} \\
1.78 \times 10^{5} \\
9.47 \times 10 \\
6.55 \times 106\end{array}$ \\
\hline
\end{tabular}

(a)These data are summarized from Table E.1-6 in Appendix E. 
contain about $166 \mathrm{Ci}$, and the total radionuclide inventory in all neutronactivated components of the reference BWR is about $6.6 \mathrm{million} \mathrm{Ci}$. The activated portion of the core shroud contains about $96 \%$ of the total radioactivity in the neutron-activated components.

\subsubsection{Dose Rates for Selected Neutron-Activated Components}

The radiation dose rates from neutron-activated components are of concern in determining waste transportation and disposal requirements. Computed dose rates for selected components at the time of final reactor shutdown are presented in Table 7.4-5. Only those radionuclides in reference radionuclide inventories 1, 2, and 3 that significantly contribute to the dose rates (either at shutdown or after a long decay time) are included.

TABLE 7.4-5. Calculated Radiation Dose Rates from Selected Neutron-Activated Reference BWR Components (a)

\begin{tabular}{|c|c|c|c|c|c|c|c|}
\hline Component & bOCo (gamma) & प94\$ए (gamma) & $\begin{array}{l}\text { Calculated Dose } \\
55 \mathrm{Fe}(\mathrm{IB}, \text { ganma) } \\
\end{array}$ & $\begin{array}{l}\text { from Selected Radic } \\
59 \mathrm{Ni} \text { (IB, gamma)(b) }\end{array}$ & 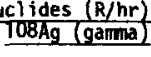 & T52Eu (gamma) & 154Eu (ganma) \\
\hline $\begin{array}{l}\text { Core Shroud } \\
\text { Inner Surface } \\
\text { Outer Surface }\end{array}$ & $\begin{array}{l}1.2 \times 10^{5} \\
3.3 \times 10^{4}\end{array}$ & $\begin{array}{l}7 \times 10^{-1} \\
2 \times 10^{-1}\end{array}$ & $\begin{array}{l}8 \times 10^{-2} \\
1 \times 10^{-2}\end{array}$ & $\begin{array}{l}7 \times 10^{-2} \\
2 \times 10^{-2}\end{array}$ & $\begin{array}{c}2 \times 10^{-2} \\
-\cdots(c)\end{array}$ & $2 \times 10^{-4}$ & $5 \times 10^{-1}$ \\
\hline $\begin{array}{l}\text { Reactor Vessel } \\
\text { Inner Surface } \\
\text { Outer Surface }\end{array}$ & $\begin{array}{l}1.4 \times 10^{1} \\
1.4 \times 10^{-1}\end{array}$ & $\begin{array}{l}1 \times 10^{-4} \\
4 \times 10^{-9}\end{array}$ & $\begin{array}{l}3 \times 10^{-5} \\
1 \times 10^{-6}\end{array}$ & $\begin{array}{l}2 \times 10^{-5} \\
7 \times 10^{-8}\end{array}$ & $\begin{array}{l}--\cdot \\
-\cdots\end{array}$ & 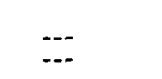 & --. \\
\hline $\begin{array}{l}\text { Sacrificial Shield } \\
\text { Inner Surface } \\
\text { Outer Surface }\end{array}$ & $\begin{array}{l}3.2 \times 10^{-1} \\
9 \times 10^{-4}\end{array}$ & --- & $\begin{array}{l}3 \times 10^{-6} \\
1 \times 10^{-8}\end{array}$ & $\begin{array}{l}2 \times 10^{-7} \\
1 \times 10^{-9}\end{array}$ & $8 \times 10^{-8}$ & $7 \times 10^{-3}$ & $7 \times 10^{-5}$ \\
\hline
\end{tabular}

(a)Calculated at a distance of $10 \mathrm{~mm}$ from the surface of the activated component, at the axial midplane of the fuel zone, and at final reactor shutdown: these data are identical to those presented in Table E.1-7 in Appendix E.

(b) IB means "inner bremsstrahlung."
(c) Indicates the quantity was not calculated.

The time dependence of radioactivity concentrations and dose rates of selected radionuclides is shown in Figure 7.4-2. The data are those calculated for the core shroud. The decay rate of ${ }^{63} \mathrm{Ni}$ controls the reduction of the total radioactivity present after the first 10 years; however, the decay rate of ${ }^{60}$ Co controls the reduction of the radiation dose rate for the first 70 years. After that time, the dose rate is increasingly dominated by ${ }^{94} \mathrm{Nb}$. The dose rate is the significant factor in decommissioning work, since it directly affects occupational radiation exposure and has a strong influence on work plans and methods. 


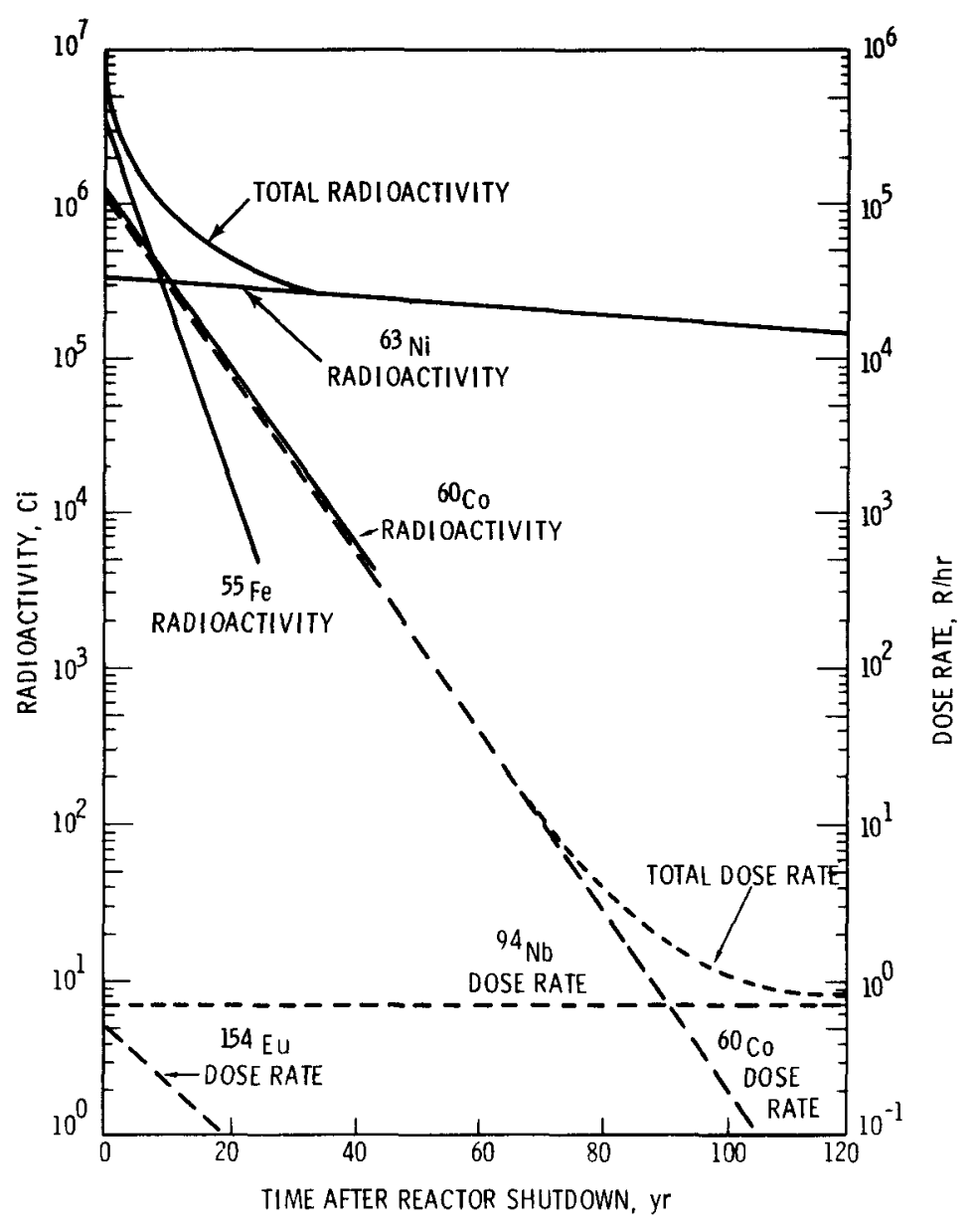

FIGURE 7.4-2. Time Dependence of Radioactivity and Dose Rate in the Neutron-Activated Core Shroud

\subsubsection{Surface Contamination}

Both activated corrosion products (from structural materials in contact with the reactor water) and fission products (from leaking fuel) contribute to the radionuclide mixtures and levels of surface contamination. This subsection contains summaries of the radionuclide inventories and depositions of both internal surface contamination in piping and equipment and external surface contamination inside the reference BWR and on the surrounding site. 


\subsubsection{Internal Surface Contamination}

Specific alloys used in the structural components of the reactor coolant system play a major role in the composition of the internal surface contamination. The activated corrosion product ${ }^{60} \mathrm{Co}$ is dominant in a BWR because of the abundance of its parent in structural materials, its large-formation cross section, its energetic decay, and its relatively long decay half-life. Cobalt-58 is only a minor source of radiation in a BWR, while in a PWR it is a significant contributor to the shutdown radiation levels. (5) Depending on the type of condenser tubes and condensate polishing system used, ${ }^{65} \mathrm{Zn}$ could be an isotope of concern.

Mobile fission products from leaking reactor fuel also contribute to the internal surface contamination. Their concentrations are directly related to the number of leaking fuel elements in the reactor core and thus will change during plant operation.

It is not within the scope of this study to fully investigate the complex mechanisms that influence the deposition of activated corrosion products and fission products on the internal surfaces of BWR equipment and piping; nor is it within the study scope to predict with any certainty the radionuclide mixture present on piping surfaces at the time of reactor shutdown. After a review of literature on the subject, the composition of internal surface contamination assumed in this study is based on the radionuclides found in a BWR sludge sample. ${ }^{(6)}$ This composition is used as reference radionuclide inventory 4 and is summarized in Table 7.4-6. Reference radionuclide inventory 4 contains representative levels of both activated corrosion products and fission products present in the reactor water systems.

\subsubsection{External Surface Contamination in the Reference BWR}

The mixtures of radionuclides found on external structural surfaces in the reference BWR is calculated based on an accumulation of the radionuclides present in the reactor water on a surface over the 30 EFPY plant life. (7) The resulting mixture accounts for both continuous accumulation and radioactive decay. External surface radioactive contamination at shutdown is characterized by reference radionuclide inventory 5 , which is shown in Table 7.4-7. 
TABLE 7.4-6. $\begin{aligned} & \text { Reference Radionuclide Inventory } 4 \\ & \text { BWR Internal Surface Contamination }(a)\end{aligned}$

\begin{tabular}{|c|c|}
\hline Radionuclide & $\begin{array}{l}\text { Fractional } \\
\text { Radioactivity } \\
\text { at Shutdown }\end{array}$ \\
\hline $\begin{array}{l}51 \mathrm{cr} \\
54^{\mathrm{m}} \\
59_{\mathrm{Fe}}^{\mathrm{me}}\end{array}$ & $\begin{array}{l}2.1 \times 10^{-2} \\
3.9 \times 10^{-1} \\
2.5 \times 10^{-2}\end{array}$ \\
\hline $\begin{array}{l}58 \mathrm{CO} \\
60 \mathrm{Co} \\
65 \mathrm{Co}\end{array}$ & $\begin{array}{l}9.3 \times 10^{-3} \\
4.7 \times 10^{-1} \\
6.1 \times 10^{-3}\end{array}$ \\
\hline $\begin{array}{r}95 \\
95_{\mathrm{Nb}}^{\mathrm{Zr}} \\
103_{\mathrm{Ru}}\end{array}$ & $\begin{array}{l}4.0 \times 10^{-3} \\
4.0 \times 10^{-3} \\
2.3 \times 10^{-3}\end{array}$ \\
\hline $\begin{array}{l}106 \mathrm{Ru} \\
134_{\mathrm{Cs}} \\
137_{\mathrm{Cs}}\end{array}$ & $\begin{array}{l}2.8 \times 10^{-3} \\
1.9 \times 10^{-2} \\
3.4 \times 10^{-2}\end{array}$ \\
\hline $\begin{array}{l}141 \mathrm{ce} \\
144 \mathrm{ce} \\
\text { Total }\end{array}$ & $\begin{array}{l}3.0 \times 10^{-3} \\
\frac{8.1 \times 10^{-3}}{1.0}\end{array}$ \\
\hline $\begin{array}{l}\text { (a) Based on a } \\
\text { sample and } 1 \\
\text { Reference } 6 \\
\text { are a summa } \\
\text { presented 1 } \\
\text { in Appendix }\end{array}$ & $\begin{array}{l}\text { UR sludge } \\
\text { sis given in } \\
\text { These data } \\
\text { of the data } \\
\text { Table E.2-1 } \\
\text {. }\end{array}$ \\
\hline
\end{tabular}

TABLE 7.4-7. Reference Radionuclide Inventory 5, BWR Structural Surface External Contamination

\begin{tabular}{|c|c|}
\hline Radionuclide $^{(a)}$ & $\begin{array}{l}\text { Fractional } \\
\text { Radioactivity } \\
\text { at Shutdown } \\
\end{array}$ \\
\hline $\begin{array}{l}32 \mathrm{p} \\
51 \mathrm{cr} \\
54 \mathrm{mn}\end{array}$ & $\begin{array}{l}1.1 \times 10^{-3} \\
5.3 \times 10^{-2} \\
7.2 \times 10^{-4}\end{array}$ \\
\hline $\begin{array}{l}55 \\
59 \mathrm{Fe} \\
58 \mathrm{Fe} \\
58 \mathrm{Co}\end{array}$ & $\begin{array}{l}3.7 \times 10^{-1} \\
5.3 \times 10^{-4} \\
5.6 \times 10^{-3}\end{array}$ \\
\hline $\begin{array}{l}{ }^{60} \mathrm{co} \\
63^{6 \mathrm{Mi}} \\
6{ }^{\mathrm{Mn}}\end{array}$ & $\begin{array}{l}2.9 \times 10^{-1} \\
3.4 \times 10^{-3} \\
1.8 \times 10^{-2}\end{array}$ \\
\hline $\begin{array}{l}{ }^{89}{ }_{9} \mathrm{Sr} \\
90_{\mathrm{r}}\end{array}$ & $\begin{array}{l}2.0 \times 10^{-3} \\
1.5 \times 10^{-2} \\
1.5 \times 10^{-2}\end{array}$ \\
\hline $\begin{array}{l}91 \mathrm{r} \\
955 \\
95 \\
\mathrm{Nb}^{\mathrm{rr}}\end{array}$ & $\begin{array}{l}8.1 \times 10^{-4} \\
1.6 \times 10^{-4} \\
1.6 \times 10^{-4}\end{array}$ \\
\hline $\begin{array}{c}103 \mathrm{Ru} \\
106_{\mathrm{Ru}} \\
110 \mathrm{~m}_{\mathrm{Ag}}\end{array}$ & $\begin{array}{l}2.9 \times 10^{-4} \\
3.9 \times 10^{-4} \\
8.8 \times 10^{-6}\end{array}$ \\
\hline $\begin{array}{l}129 \mathrm{~m} \\
131 \mathrm{Te} \\
134 \mathrm{Is}\end{array}$ & $\begin{array}{l}4.9 \times 10^{-4} \\
1.5 \times 10^{-2} \\
8.8 \times 10^{-3}\end{array}$ \\
\hline $\begin{array}{l}136 \mathrm{Cs} \\
137 \mathrm{Cs} \\
140_{\mathrm{Ba}}\end{array}$ & $\begin{array}{l}1.0 \times 10^{-4} \\
1.8 \times 10^{-1} \\
2.0 \times 10^{-3}\end{array}$ \\
\hline $\begin{array}{l}140 \mathrm{La} \\
141 \mathrm{Ca} \\
144 \mathrm{Ce}\end{array}$ & $\begin{array}{l}2.0 \times 10^{-3} \\
2.9 \times 10^{-4} \\
2.9 \times 10^{-4}\end{array}$ \\
\hline $\begin{array}{l}143 \mathrm{Pr} \\
147_{\mathrm{Md}} \\
\text { Total }\end{array}$ & $\frac{2.0 \times 10^{-4}}{1.2 \times 10^{-5}}$ \\
\hline
\end{tabular}

(a)Radionuclides wi th half-1ives greater than 8 days and shortilved daughters of long-lived parents are included; these data are a sumary of the data
presented in Table E.2-9 in Appendix E. 


\subsubsection{External Surface Contamination on the Site}

Radionuclides are assumed to be deposited on the reference site as a result of normal BWR operation over 30 EFPY of service. Accidental releases are not expected to significantly increase the radioactivity present on the reference site, and are not considered in this analysis. Annual airborne radionuclide releases from operating BWRs vary widely and are dependent on such plant factors as size, operating conditions, and gaseous radwaste systems. For this study, the airborne releases are based on releases reported from 23 operating BWRs for 1975. ${ }^{(8)}$ Because fuel failures were higher during this period than at present, these values may produce an overestimate of normal releases expected over a plant's operating life. Ground depositions on the site are estimated as described in Appendix $E$. The radionuclide depositions on the reference BWR site at shutdown following normal BWR operation for 30 EFPY are listed in Table 7.4-8 as reference radionuclide inventory 6 .

Table 7.4-8. Reference Radionuclide Inventory 6, Reference BWR Site Surface Contamination (a)

$$
\begin{aligned}
& \text { Deposited } \\
& \text { Radioactivity }
\end{aligned}
$$

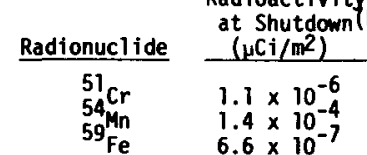

$$
\begin{aligned}
& { }_{60}^{58} \mathrm{co} \quad 1.2 \times 10^{-5} \\
& \begin{array}{ll}
60 & \mathrm{CO} \\
\mathrm{Zn} & 1.9 \times 10^{-3}
\end{array} \\
& \begin{array}{ll}
{ }^{89} \mathrm{Sr} & 4.1 \times 10^{-4} \\
{ }_{90}^{90} \mathrm{Sr} & 1.0 \times 10^{-2} \\
{ }_{\mathrm{Y}} & 1.0 \times 10^{-2}
\end{array} \\
& \begin{array}{ll}
95 & 2 r \\
95 & 2.6 \times 10^{-6} \\
106_{\mathrm{Ru}}^{\mathrm{ND}} & 2.6 \times 10^{-6} \\
& 2.7 \times 10^{-5}
\end{array} \\
& 110 \mathrm{mil} / \mathrm{Ag} \quad 1.5 \times 10^{-6} \\
& \begin{array}{ll}
124 \mathrm{Ag} & 1.5 \times 10^{-6} \\
125 \mathrm{Sb} & 1.1 \times 10^{-8} \\
13 \mathrm{Sb} & 9.7 \times 10^{-8}
\end{array} \\
& 131 \mathrm{I} \quad 1.8 \times 10^{-5} \\
& \begin{array}{ll}
133 \mathrm{I} & 1.6 \times 10^{-6} \\
134 \mathrm{Cs} & 8.5 \times 10^{-4}
\end{array} \\
& 136 \mathrm{Cs} \quad 6.9 \times 10^{-8} \\
& \begin{array}{ll}
137 \mathrm{Cs} & 1.4 \times 10^{-2} \\
140 \mathrm{Ba} & 1.2 \times 10^{-4}
\end{array} \\
& 140 \mathrm{La} \quad 1.2 \times 10^{-4} \\
& 141^{\mathrm{Ce}} \quad 3.0 \times 10^{-6} \\
& \frac{{ }^{7} \mathrm{Ce}}{\text { Total }} \frac{8.8 \times 10^{-6}}{3.8 \times 10-2}
\end{aligned}
$$

(a) Based on 1975 revorted air-

borne radionuclide releases

from 23 operating BuRs (Refe-

rence 8 ); these data are a

sumary of data presented in

Table E.2-12 in Appendix E.

(b) Based on 30 EFPY of operation. 


\subsubsection{Surface Contamination Deposition in the Reference BWR}

The surface contamination deposition in the reference BWR is based on dose rate information from operating BWRs, which is summarized in Section 7.3. The dose rates used to determine radioactivity depositions both on internal piping surfaces and building structural surfaces as well as the calculated radioactivity deposition levels and the associated reference radionuclide inventories are listed in Table 7.4-9. The geometries, material thicknesses, and radiation shielding models used to calculate these radioactivity depositions are discussed in detail in Section E.2 of Appendix E.

TABLE 7.4-9. Summary of Surface Contamination Deposition Data ${ }^{(a)}$

\begin{tabular}{|c|c|c|c|}
\hline Category & $\begin{array}{l}\text { Dose Rate } \\
(\mathrm{mR} / \mathrm{hr})(\mathrm{a})\end{array}$ & $\begin{array}{c}\text { Radioactivity } \\
\text { Deposition } \\
\text { Level } \\
\left(\mathrm{Ci} / \mathrm{m}^{2}\right)(\mathrm{b}) \\
\end{array}$ & $\begin{array}{c}\text { Reference } \\
\text { Radionuclide } \\
\text { Inventory } \\
\text { Number } \\
\end{array}$ \\
\hline $\begin{array}{l}\text { Internal Surfaces } \\
\text { Piping } \\
\text { Reactor Water } \\
\text { Steam/Air } \\
\text { Condensate }\end{array}$ & $\begin{array}{l}7.0 \times 10^{2} \\
7.0 \times 10 \\
5.0 \times 10\end{array}$ & $\begin{array}{l}1.1 \times 10^{0} \\
5.0 \times 10^{-3} \\
5.0 \times 10^{-2}\end{array}$ & $\begin{array}{l}4 \\
4 \\
4\end{array}$ \\
\hline $\begin{array}{l}\text { Equipment } \\
\text { Reactor Water } \\
\text { Steam/Air } \\
\text { Turbine }\end{array}$ & $1.0 \times 10^{4}$ & $\begin{array}{l}3.6 \times 10^{-1} \\
5.0 \times 10^{-3(b)} \\
5.0 \times 10^{-4(c)}\end{array}$ & $\begin{array}{l}4 \\
4 \\
4\end{array}$ \\
\hline $\begin{array}{l}\text { Condensate } \\
\text { Condenser/Feedwater } \\
\text { Heaters } \\
\text { Concentrated waste } \\
\text { Tanks }\end{array}$ & & $\begin{array}{l}5.0 \times 10^{-2(b)} \\
5.0 \times 10^{-3(c)} \\
5.0 \times 10^{0(c)}\end{array}$ & $\begin{array}{l}4 \\
4 \\
4\end{array}$ \\
\hline $\begin{array}{l}\text { External Surfaces } \\
\text { Low-Level Contamina- } \\
\text { tion } \\
\text { High-Level Contamina- } \\
\text { tion }\end{array}$ & $\begin{array}{l}1.0 \times 10^{1(d)} \\
1.0 \times 10^{2(d)}\end{array}$ & $\begin{array}{l}2.5 \times 10^{-3} \\
2.5 \times 10^{-2}\end{array}$ & $\begin{array}{l}5 \\
5\end{array}$ \\
\hline
\end{tabular}

(a) From information supporting and presented in Tables E.2-4, E.2-6 and E.2-10 in Appendix E.

(b) Assumed the same as for the corresponding piping.

(c) The turbine and the condenser/feedwater heaters are assumed to be a factor of 10 less contaminated than the steam/air and condensate piping, respectively; the concentrated waste tanks are assumed to be a factor of 100 more contaminated than the condensate piping.

(d) The assumed dose rate $1 \mathrm{~m}$ in air from the surface. 
The estimated radioactivity depositions, both on internal piping and equipment surfaces and on external structural surfaces in the reference BWR, are summarized in Table 7.4-10. A total of $8.5 \times 10^{3} \mathrm{Ci}$ of reference radionuclide inventory 4 is estimated to be present on internal piping and equipment surfaces. For external structural surfaces, a total of about $110 \mathrm{Ci}$ of reference radionuclide inventory 5 is estimated to be present. Further details on the estimated contamination by specific equipment items and building location are given in Section E.2.

TABLE 7.4-10. Summary of Surface Contamination in the Reference BWR(a)

\begin{tabular}{|c|c|c|}
\hline $\begin{array}{l}\text { Category } \\
\text { Building }\end{array}$ & $\begin{array}{l}\text { Estimated } \\
\text { Total } \\
\text { Surface } \\
\text { Area }\left(\mathrm{m}^{2}\right) \\
\end{array}$ & $\begin{array}{c}\text { Deposited } \\
\text { Radioactivity } \\
\text { (Ci) }\end{array}$ \\
\hline \multicolumn{3}{|l|}{ Internal Surfaces } \\
\hline Piping & $3.4 \times 10^{4}$ & $2.2 \times 10^{3}$ \\
\hline \multicolumn{3}{|l|}{ Equipment } \\
\hline $\begin{array}{l}\text { Reactor Building } \\
\text { Turbine Generator Building } \\
\text { Radwaste and Control Building }\end{array}$ & $\begin{array}{l}8.6 \times 10^{3} \\
2.0 \times 10^{5} \\
1.4 \times 10^{3}\end{array}$ & $\begin{array}{l}1.9 \times 10^{3} \\
1.2 \times 10^{3} \\
3.2 \times 10^{3} \\
\end{array}$ \\
\hline Subtotal, Internal Surfaces & & $8.5 \times 10^{3(b)}$ \\
\hline \multicolumn{3}{|l|}{ External Surfaces } \\
\hline $\begin{array}{l}\text { Reactor Building } \\
\text { Turbine Generator Building } \\
\text { Radwaste and Control Building. }\end{array}$ & $\begin{array}{l}5.2 \times 10^{3} \\
1.9 \times 10^{3} \\
2.0 \times 10^{3}\end{array}$ & $\begin{array}{l}7.4 \times 10^{1} \\
4.4 \times 10^{0} \\
3.6 \times 10^{1} \\
\end{array}$ \\
\hline Subtotal, External Surfaces & & $\frac{1.1 \times 10^{2(c)}}{3}$ \\
\hline Total & & $8.6 \times 10^{3}$ \\
\hline
\end{tabular}

(a)Based on information presented in Tables E.2-5 and E.2-10 in Appendix E.

(b) Internal surface radioactivity is defined as reference radionuclide inventory 4.

(c) External structural surface radioactivity is defined as reference radionuclide inventory 5 . 
The reduction of the dose rate with time because of radioactive decay of a mixture of activated corrosion products and fission products is shown in Figure 7.4-3. In the figure, the total dose rate is normalized to unity at shutdown and is based on reference radionuclide inventory 4 . The activated corrosion product ${ }^{60} \mathrm{Co}$ controls the dose rate of the mixture until about 50 years after final shutdown, when ${ }^{137}$ Cs begins to dominate. Dose rates from piping, equipment, and structural surfaces are a significant factor in planning decommissioning operations. As shown in the figure, the dose rate from the mixture of radionuclides in reference inventory 4 is reduced by about a factor of 100 at about 30 years after shutdown.

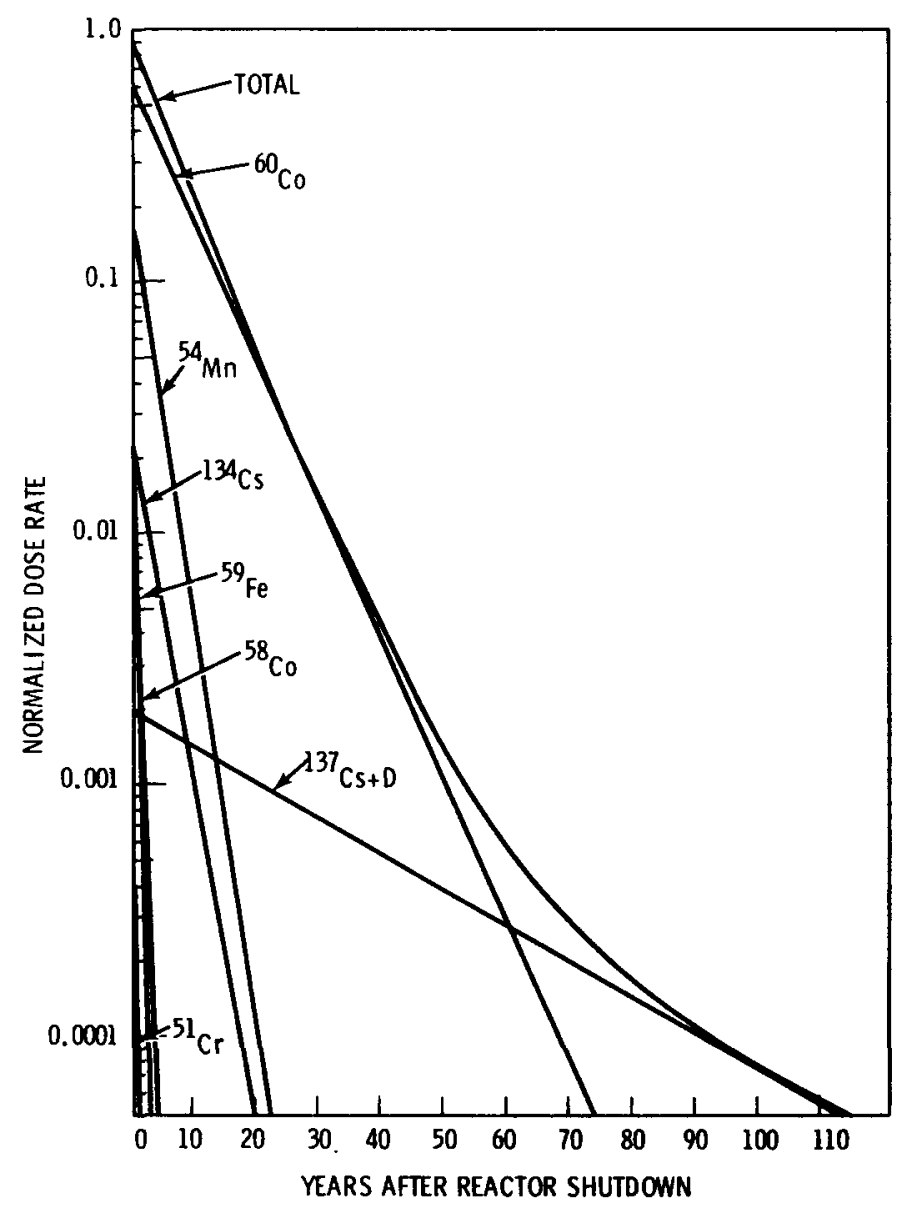

FIGURE 7.4-3. Radioactive Decay of Deposited Internal Surface Contamination 


\subsection{CHEMICAL INVENTORY}

The expected annual chemical usage during operation of the reference BWR is shown in Table 7.5-1. A nominal 3-month inventory of chemicals is kept on hand. Most of these chemicals are assumed to be used or removed prior to decomissioning and, for this study, the inventory of these chemicals at the start of decommissioning is assumed to be limited to residuals in vessels and piping.

TABLE 7.5-1. Expected Annual Chemical Usage During Reference BWR Operation

\begin{tabular}{lcccc}
\multicolumn{1}{c}{ Chemical } & $\begin{array}{c}\text { Expected Annual } \\
\text { Usage }(\mathrm{kg})\end{array}$ & & Purpose \\
\cline { 1 - 1 } Sulfuric Acid & $2.2 \times 10^{5}$ to $4.5 \times 10^{5}$ & $\begin{array}{c}\text { Control of } \mathrm{pH} \text { in cooling water and } \\
\text { regeneration of makeup water demin- } \\
\text { eralizer }\end{array}$ \\
Chlorine & $3.2 \times 10^{4}$ & $\begin{array}{c}\text { Prevention of biological growth } \\
\text { Sodium Hydroxide }\end{array}$ & $1.8 \times 10^{3}$ & $\begin{array}{c}\text { Makeup water demineralizer regenera- } \\
\text { tion }\end{array}$ \\
Alum & $2.6 \times 10^{1}$ & Clarification of primary makeup water
\end{tabular}




\section{REFERENCES}

1. U.S. AEC, Final Environmental Statement Concerning Proposed Rule-Making Action: Numerical Guides for Design Objectives and Limiting Conditions for Operation to Meet the Criteria "As Low As Practicable" for Radioactive Material in Light Water-Cooled Nuclear Power Reactor Effluents, WASH-1258, Directorate of Regulatory Standards, Volume 1 of 3 , Figure $6 \mathrm{~B}-1, \mathrm{p} .6 \mathrm{~B}-43$ and Figure 6C-8, p. 6C-12, July 1973.

2. U.S. AEC, Final Environmental Statement Related to Operation of Monticello Nuclear Generating Plant, Docket No. 50-263, pp. II-15 to II-26, November 1972.

3. U.S. AEC Regulatory Guide 1.86, Termination of Operating Licenses for Nuclear Reactors, June 1974.

4. WPPSS Nuclear Project No. 2 Final Safety Analysis Report, Washington Public Power Supply System, Richland, WA, March 1977.

5. R. I. Smith, G. J. Konzek and W. E. Kennedy, Jr., Technology, Safety and Costs of Decommissioning a Reference Pressurized Water Reactor Power Station, NUREG/CR-0130, Section 7, U.S. Nuclear Regulatory Commission Report by Pacific Northwest Laboratory, June 1978. *

6. S. G. Sawochka, N. P. Jacob and W. L. Pearl, Primary System Shutdown Radiation Levels at Nuclear Power Generating Stations, EPRI 404-2, Final Report, Prepared by Nuclear Water and Waste Technology for the Electric Power Research Institute, Palo Alto, CA, pp. 8-24, 1975.

7. U.S. NRC, Calculation of Releases of Radioactive Materials in Gaseous and Liquid Effluents from Boiling Water Reactors (BWR - Gale Code), NUREG-0016, Table 2-2, pp. 2-3, 2-5, Apri1 1976. **

8. U.S. NRC, Radioactive Materials Released from Nuclear Power Plants (1975), NUREG-0218, March 1977. **

\footnotetext{
${ }^{\star}$ Available for purchase from the NRC/GPO Sales Program, U.S. Nuclear Regulatory Commission, Washington, D.C. 20555, and the National Technical Information Service, Springfield, Virginia 22161.

**Available for purchase from the National Technical Information Service, Springfield, Virginia 22161.
} 


\title{
CHAPTER 8
}

\author{
SUGGESTED METHODOLOGY FOR DETERMINING \\ ACCEPTABLE RESIDUAL RADIOACTIVE CONTAMINATION \\ LEVELS FOR THE DECOMMISSIONED BWR
}

This chapter contains a discussion of a suggested methodology for determining acceptable levels of residual radioactive contamination for decommissioned nuclear facilities. A demonstration of this methodology, using the reference radionuclide inventories and reference site associated with the reference BWR, is also presented.

Detailed information about the mixture of radionuclides found in the reference BWR facility and on its site prior to decommissioning is contained in Appendix E. Descriptions of the reference site and facility are presented in Appendices $B$ and $C$, respectively. Discussion of the radiation dose models and parameters used to determine acceptable radioactive contamination levels is presented in Appendix F.

\subsection{TECHNICAL APPROACH}

The ultimate disposition of a decommissioned nuclear facility and its surrounding site depends on the degree and type of radioactive contamination present. Examination of existing guidelines and regulations shows a need for a general method of deriving acceptable levels of radioactive contamination to permit the unrestricted release of any decommissioned nuclear facility or site. (1) Currently, some guidance exists that defines levels of radioactive surface contamination that are acceptable to the U.S. Nuclear Regulatory Commission (NRC) for the termination of operating licenses. $(2,3)$ other guidance addresses specific types of nuclear facilities or accident situations involving radioactivity. ${ }^{(4-9)}$

None of these guidelines are flexible enough to accommodate the various radionuclide mixtures or site-specific features found at each unique nuclear facility. This suggests that the methodology used to calculate the acceptable levels of residual radioactive contamination at decommissioned 
nuclear facilities should be based on a general concept capable of accommodating these unique radionuclide mixtures and site-specific features. One such general concept is to compare established annual dose limits with calculated annual doses to members of the public to determine acceptable radioactive contamination levels. The contamination levels derived from a maximum annual dose concept take into account the exposure of individuals to contamination remaining at a decommissioned facility or on its site following unrestricted release.

\subsubsection{Terminology and Definitions}

The following terminology and definitions are used in developing a methodology for determining acceptable residual radioactive contamination levels based on annual dose:

Organs of Reference. The organs of the human body for which radiation doses are calculated. For this study, the organs of reference are the total body, lungs, bone, and thyroid. The total body is the head and trunk of the human body and includes active blood-forming organs, eye lenses, and gonads.

Exposure Pathways. The potential routes by which people may be exposed to radionuclides or radiation. Radiation exposure pathways in the environment that are considered in this study are: external exposure to contamination deposited on the ground, ingestion of food products containing radionuclides, and inhalation of airborne radionuclides. Radiation exposure pathways inside the BWR facility are: external exposure from contaminated or activated room surfaces or equipment and inhalation of airborne radionuclides. External exposure from airborne radionuclides (air submersion) is not considered, since previous decommissioning studies have shown this exposure pathway to be insignificant compared to the others. $(1,10,11)$

Decay Periods. The mixtures of radionuclides in the residual inventories are constantly changing because of radioactive decay, resulting in annual doses that vary with time. This time dependence is demonstrated by calculating the doses at shutdown and at 10,30, 50, and 100 years after shutdown of the reference BWR. 
Maximum-Exposed Individual. The individual who receives the maximum radiation dose to an organ of reference. The maximum-exposed individual is assumed to reside at the location of the highest airborne radionuclide concentration. Maximized exposure pathway parameters are used.

Annual Dose. The radiation dose equivalent calculated during any year following the start of continuous exposure. It is the sum of the dose received by an organ of reference during the year of interest from all exposure pathways and the dose received during that year from radionuclides deposited in the organ of reference during the previous years.

Maximum Annual Dose. The largest of the annual doses calculated to occur during the 50 years following the start of continuous exposure.

Additional terminology, radiation dose models and parameters, and derivations of the equations used to determine the annual dose are contained in Appendix $F$ of Volume 2 .

\subsubsection{Definition of Use Categories}

During the planning stages of decommissioning, a variety of future uses for the BWR facility and/or site can be considered. These future uses fall into two general categories:

- Restricted Use - permits activities at the decommissioned BWR within a nuclear-license restriction. Since this category requires a continuation of a nuclear license, the residual radioactive contamination levels may be similar to those found at other licensed operating nuclear facilities. Therefore, public and occupational exposure are controlled by the restrictions imposed by the nuclear license.

- Unrestricted Use - permits, without license restrictions, public use of the released portions of the decommissioned BWR. For this study, the potential exposure to members of the public from residual radioactive contamination is assumed limited to an annual dose of $50 \mathrm{mrem}$ to the maximum-exposed individual. In general, decommissioning the reference site may result in return of the land to public use. 
No attempt is made to define all of the possible specific uses that may fall into these general categories. Continuing care is required to enforce the license restrictions of the restricted use category for the time period involved.

The unrestricted use category is the only one for which example acceptable residual contamination levels are calculated in this study. Acceptable contamination levels are calculated for 1) a reference room within the facility and 2) on the reference site. As a demonstration of the methodology, the site is assumed to be used for farming activities after decommissioning.

\subsubsection{Acceptable Radioactive Contamination Level Methodology}

Determination of acceptable radioactive contamination levels for the reference BWR is necessarily linked with other decommissioning considerations. The relationship of these levels to both generic and site-specific studies is shown in Figure 8.1-1.

Acceptable radioactive contamination levels are calculated using a previously developed methodology, ${ }^{(1)}$ together with the reference radionuclide inventories, the facility design, and the site parameters discussed in detail in the appendices. The methodology for determining acceptable radioactive contamination levels is based on the assumption that an annual radiation dose limit is established for decommissioned nuclear facilities. Currently, there are no unique regulations or specific guidance on acceptable annual radiation doses to individuals working in the decommissioned facility or living on the decommissioned site. Guidance that could be interpreted as recommending annual radiation dose limits for decommissioned properties includes:

- Recommendations of the International Commission on Radiological Protection (ICRP), Publication 9. (12)

- Surgeon General's Guidelines (DHEW).

- Appendix I of 10 CFR 50, Guides for Design Objectives for Light-WaterCooled Nuclear Power Reactors (NRC).

- Proposed Federal Guidance for the Environmental Limits of Transuranium Elements (EPA). (15)

- 40 CFR 190, Environmental Radiation Protection Standards for Normal Operations of Activities in the Uranium Fuel Cycle (EPA). (16) 


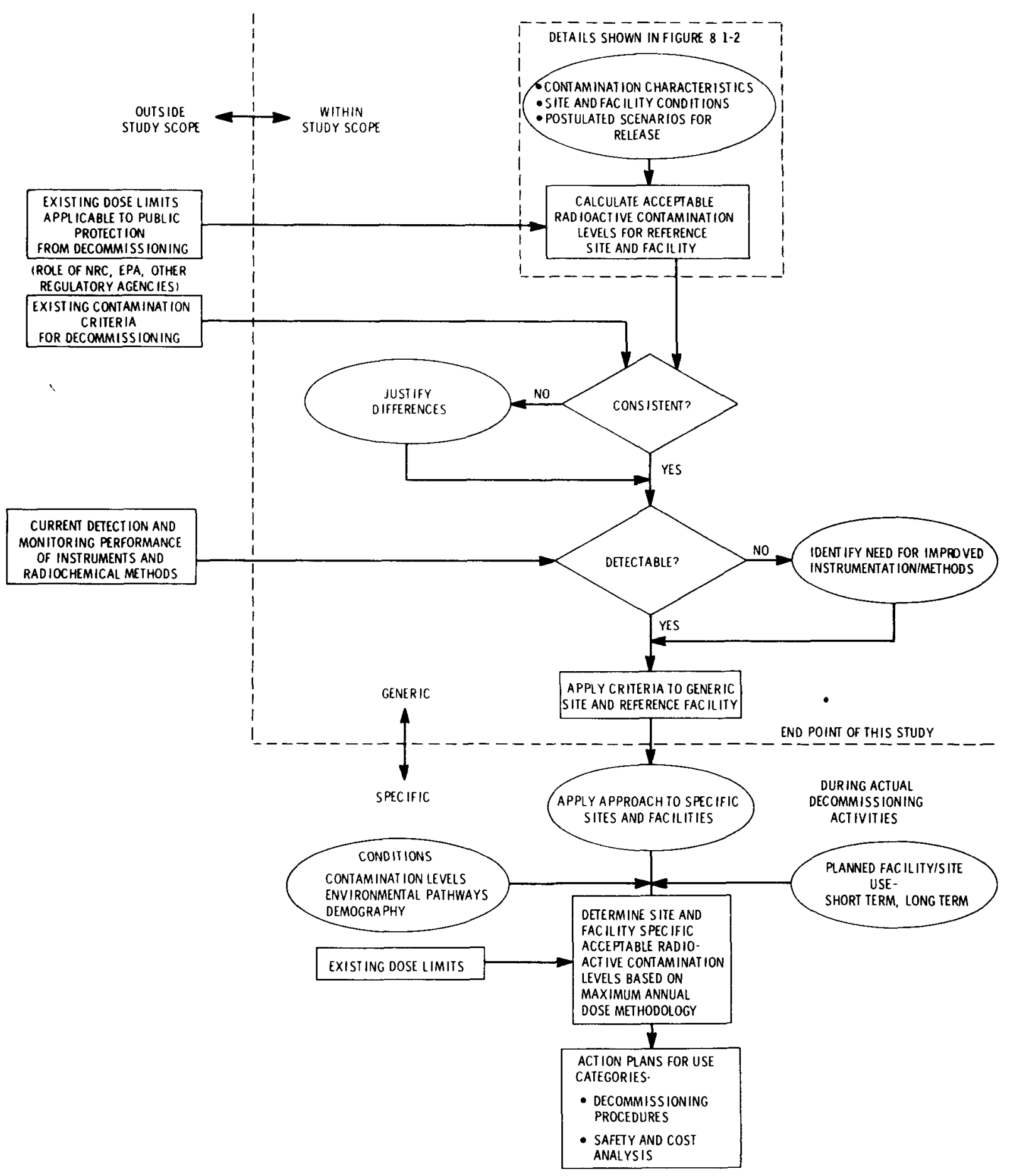

FIGURE 8.1-1. Relationship of Acceptable Radioactive Contamination Levels to Generic and Site-Specific Studies 
None of this guidance, written to provide limits for operating nuclear facilities, specifically addresses decommissioned nuclear facilities or sites. However, this guidance suggests annual total body radiation dose limits ranging from 3 to $500 \mathrm{mrem} / \mathrm{yr}$. (1)

It is beyond the scope of this study to recommend annual radiation dose limits for public exposure to radioactive materials. Instead, acceptable residual radioactive contamination levels are calculated for a single assumed annual radiation dose 1 imit of $50 \mathrm{mrem} / \mathrm{yr}$. The selection of this assumed limit is not intended, nor should it be inferred as a recommendation for restricting public radiation exposure from decommissioned nuclear facilities. Corresponding levels for any other radiation dose 1 imit can be found through direct ratio. It is also assumed that any annual dose limit established for decommissioning applies to the maximum annual dose to any organ of reference, thus ensuring that applicable regulatory limits on annual radiation dose will not be exceeded.

The methodology for determining radioactive contamination levels, based on annual radiation dose, is illustrated in Figure $8.1-2$ and is briefly discussed below:

Calculation of the Maximum Annual Radiation Dose for the Use Category Selected

For this study, the maximum annual radiation dose during 50 years of continuous exposure after decommissioning is calculated using the dose models discussed in Appendix F. Characteristic radionuclide inventories at the reference BWR, used in the calculations, are presented in Appendix E. Maximum annual radiation doses are calculated for the decay periods of interest to illustrate the time dependence of the radionuclide inventories. Site-specific exposure pathway parameters, defined for the reference site in Appendix $B$, are used in these dose calculations. After decommissioning unrestricted use of the facility and site is assumed.

Comparison of the Maximum Annual Dose to the Annual Dose Limit

For this study, since assumed or calculated levels of contamination are used, no direct comparison is made. Rather, the quantities of the radionuclide 


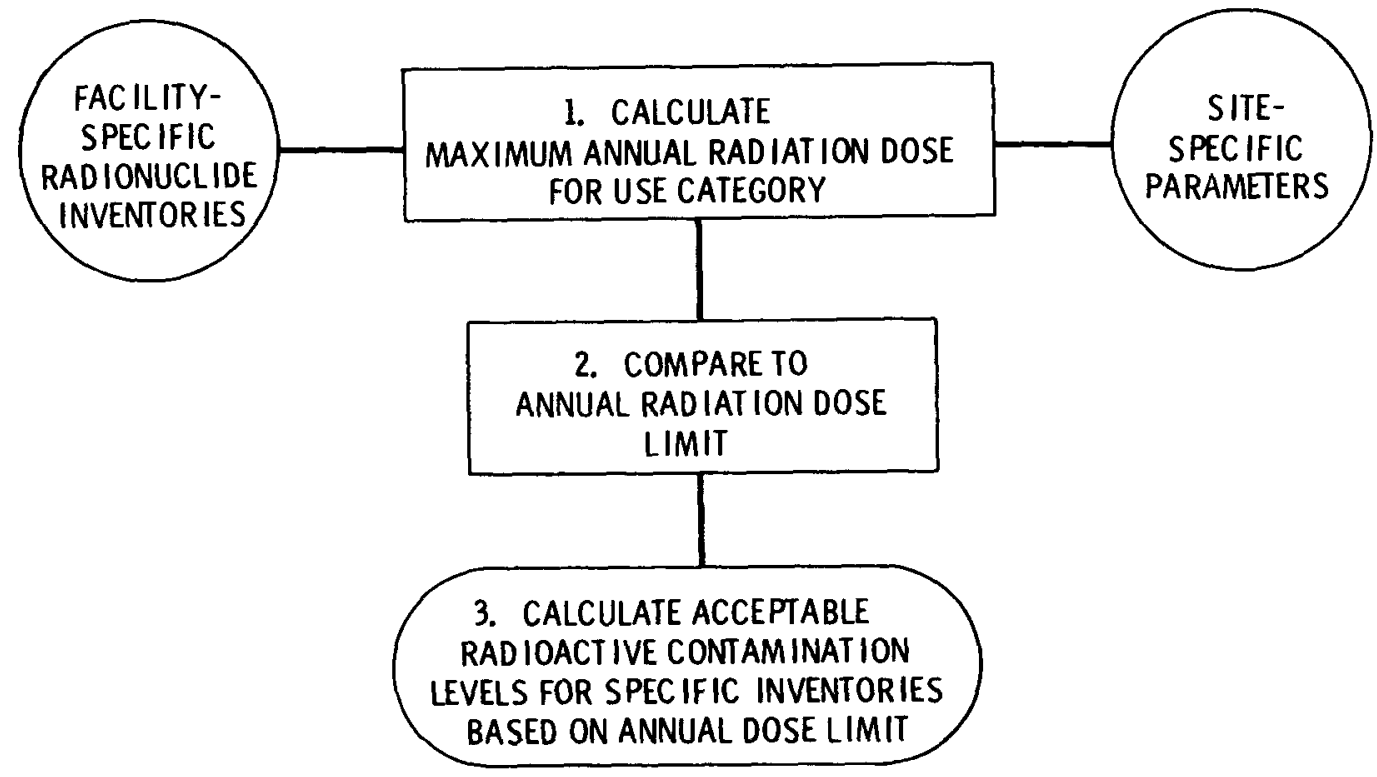

FIGURE 8.1-2. Suggested Methodology for Determining Acceptable Residual Radioactive Contamination Levels

inventories corresponding to a dose of $50 \mathrm{mrem} / \mathrm{yr}$ are calculated to demonstrate the suggested methodology both for the facility and for the site. In sitespecific studies that use measured radioactivity levels this step can be used as a decision point to determine the need for further decontamination efforts.

Calculation of Acceptable Levels Based on the Assumed Dose Limit

The acceptable radioactive contamination levels in the decommissioned reference BWR facility and on its site are calculated and presented in the next section. These reported levels are determined by selecting the largest calculated organ dose derived from a11 exposure pathways. Acceptable contamination levels are reported in units of $\mu \mathrm{Ci} / \mathrm{m}^{2}$ of surface area.

\subsection{EXAMPLE CALCULATIONS OF ACCEPTABLE RADIOACTIVE CONTAMINATION LEVELS FOR} THE DECOMMISSIONED REFERENCE BWR

The methodology for developing acceptable contamination levels is best demonstrated by calculating example levels for the reference BWR facility and $i$ ts site. 


\subsubsection{Acceptable Residual Radioactive Contamination Levels in the Reference BWR Facility}

Example acceptable radioactive contamination levels for the decommissioned reference BWR facility are calculated for the surface contamination characterized by reference radionuclide inventory 5 , using the methodology presented in Appendix $F$. Contamination is assumed to accumulate on a surface for the entire 30 effective full-power years (EFPY) of BWR operating life as a result of a postulated reactor water leak. The quantity of surface contamination in the reference BWR is difficult to predict, since it is specific to each BWR, and is best determined by measurement on a case-by-case basis at the time of shutdown. Therefore, surface contamination levels are normalized to $1 \mu \mathrm{Ci} / \mathrm{m}^{2}$ at shutdown. To perform the calculations, it is necessary to predict the isotopic composition of this contamination. The actual radioactivity levels and isotopic composition at the facility are important in determining the degree of decontamination required; however, only the isotopic composition is necessary to determine the acceptable radioactive contamination levels.

The residual radioactive contamination levels present during decommissioning are assumed to be appropriately monitored and suitably recorded. The decommissioning operations discussed in Chapter 9 and Appendix I are designed to remove surface radioactive contamination until the residual levels are acceptable for unrestricted use. These acceptable contamination levels for the facility are derived here based on radioactive surface contamination, with the assumption that all volumetric wastes generated during decommissioning are disposed of as radioactive wastes.

Acceptable radioactive contamination levels in the reference BWR facility are calculated based on reference room model, as discussed in Section F.3.1 of volume 2. The room is assumed to have a floor surface area of $154 \mathrm{~m}^{2}$ and walls $3 \mathrm{~m}$ high. A uniform deposition of radioactive contamination is assumed to be present on all of its surfaces (i.e., the floor, walls, and ceiling). For the maximum annual dose calculations, airborne radionuclide concentrations in the BWR facility are calculated using a constant resuspension factor of $5 \times 10^{-6} \mathrm{~m}^{-1}$, as discussed in Section F.3. Results of actual measurements 
of airborne radionuclide concentrations in decommissioned facilities could alter the allowable contamination levels calculated here.

The maximum annual doses to workers in the decommissioned BWR facility after it is released for unrestricted use, are calculated using a 40-hour work week of continuing exposure for 50 years. Calculated maximum annual doses for the decay periods of interest are shown in Table F.4-1. Calculated doses to selected organs of reference for inhalation and external exposure pathways are listed for radionuclides that contribute at least $0.5 \%$ to the organ dose. Ingestion pathways for workers in the decommissioned BWR facility are assumed to be non-existent.

Acceptable radioactive contamination levels for the most restrictive organs of reference are next calculated for a maximum annual dose of $50 \mathrm{mrem}$ per year. These levels are expressed in units of microcuries per $\mathrm{m}^{2}\left(\mu \mathrm{Ci} / \mathrm{m}^{2}\right)$, and are shown for the decay times of interest in Table 8.2-1.

TABLE 8.2-1. Example Acceptable Residual Radioactive Contamination Levels for Inside the Reference BWR $(a)$

Time Exposure

Begins

(Years after

Shutdown) (b)

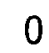

10

30

50

100

\begin{tabular}{lll}
$\begin{array}{ll}\text { Limiting } \\
\text { Organ of } \\
\text { Reference }\end{array}$ & $\begin{array}{l}\text { Dominant } \\
\text { Radionuclide } \\
\text { Contributor } \\
\text { To Dose }\end{array}$ \\
\cline { 1 - 1 } Lungs & & ${ }^{60} \mathrm{Co}$ \\
Lungs & & ${ }^{60} \mathrm{Co}$ \\
Lungs & ${ }^{137} \mathrm{Cs} /{ }^{60} \mathrm{Co}$ \\
Bone & ${ }^{137} \mathrm{Cs}$ \\
Bone & ${ }^{137} \mathrm{Cs}$
\end{tabular}

Acceptable Residual Contamination Levels $\left(\mu \mathrm{Ci} / \mathrm{m}^{2}\right)$

0.55

0.45

0.68

0.78

0.82

(a)Corresponding to the annual dose of $50 \mathrm{mrem} / \mathrm{yr}$.

(b) The time that continuous exposure begins.

External exposure is the dominant exposure pathway at all decay times, with only a small contribution from inhalation. However, it is the inhalation contribution to the total radiation dose that determines the most restrictive 
organ of reference. At shutdown and 10 years after, the acceptable radioactive contamination levels are controlled by the dose from ${ }^{60} \mathrm{Co}$ to the lungs. At longer decay times after shutdown, the acceptable contamination levels become dominated by the dose to bone from ${ }^{137} \mathrm{Cs}$ and its short-lived daughter ${ }^{137 \mathrm{~m}_{\mathrm{Ba}}}$. The change in the acceptable radioactive contamination level with time reflects the change in the residual mixture with time, because of radioactive decay. Since external exposure from contaminated room surfaces is the dominant exposure pathway, and since the higher-energy gammas from ${ }^{60} \mathrm{Co}$ are more penetrating than either the beta from ${ }^{137} \mathrm{Cs}$ or the lower-energy gamma from its daughter ${ }^{137_{\mathrm{m}} \mathrm{Ba}}$, the acceptable contamination level of the mixture is more restrictive at shorter decay times, when ${ }^{60} C_{0}$ is present in relatively larger quantities.

\subsubsection{Acceptable Residual Radioactive Contamination Levels on the Reference BWR Site}

Information about the nature and mixture of radionuclides present on the BWR site as a result of 30 EFPY of operation is based on reported atmospheric radioactivity releases from 23 operating BWR power plants. (17) The radionuclide inventory for the site is shown as reference radionuclide inventory 6 in Table E.2-10 of Volume 2. The radioactive contamination level present on the site is calculated using the dry deposition model discussed in Section E.2.3.1. Careful accounting of radioactive decay and daughter-product ingrowth is performed to obtain the radionuclide mixtures present at the various decay periods after plant shutdown.

Airborne concentrations of radionuclides in the environment are calculated using the time-dependent resuspension factor discussed in Section F.3.2 of Volume 2. At plant shutdown, the radionuclides are assumed to be mixed in soil to a depth of $10 \mathrm{~mm}$, with no mechanical mixing or weathering effects. After decommissioning, the site is assumed to be used for farming, and plowing is assumed to mix the radioactive contamination to a depth of $0.15 \mathrm{~m}$. A dry soil "surface-density" factor of $224 \mathrm{~kg} / \mathrm{m}^{2}$ mixed to a depth of $0.15 \mathrm{~m}$, is used to determine the soil radioactivity concentration. It should be noted that the radioactive contamination levels defined for the site in Table E.2-10 are probably higher than those that might be encountered at an actual BWR. This 
is primarily because no credit is taken for weathering effects on the radioactive contamination, either during the BWR operating life or during the decay periods following shutdown. For specific sites, comprehensive measurements will be necessary at shutdown to characterize the quantity and mixture of the deposited radioactive contamination.

Maximum annual doses calculated for reference radionuclide inventory 6 are listed in Table F.4-2 at the decay times of interest for each of four organs of reference. This table contains the calculated doses for each exposure pathway, with listings of those radionuclides contributing $0.5 \%$ or more to the annual dose to any organ. Calculated residual radioactive contamination levels on the decommissioned BWR site for the organs of reference, corresponding to an annual dose limit of $50 \mathrm{mrem}$, are listed in Table 8.2-2.

TABLE 8.2-2. Example Residual Radioactive Contamination Levels for the Decommissioned BWR Site(a)

\begin{tabular}{|c|c|c|c|c|c|c|}
\hline $\begin{array}{l}\text { Time Exposure } \\
\text { Begins }\end{array}$ & & & $\begin{array}{l}\text { Dominant } \\
\text { Radionuclide }\end{array}$ & $\begin{array}{l}\text { Acceptable Residual } \\
\text { Radioactive Surface }\end{array}$ & $\begin{array}{r}\text { Accepta } \\
\text { Contamina } \\
\end{array}$ & $\begin{array}{l}\text { le Soil } \\
\text { ion Levels }\end{array}$ \\
\hline $\begin{array}{l}\text { (Years after } \\
\text { Shutdown)(b) }\end{array}$ & $\begin{array}{l}\text { Maximum } \\
\text { Year(c) }\end{array}$ & $\begin{array}{r}\text { Organ of } \\
\text { Reference }\end{array}$ & $\begin{array}{l}\text { Contributors } \\
\text { To Dose }\end{array}$ & $\begin{array}{c}\begin{array}{c}\text { Contamination Levels } \\
\left(\mu \mathrm{Ci} / \mathrm{m}^{2}\right)\end{array} \\
\end{array}$ & $\begin{array}{l}\text { Mixed to } 10 \mathrm{~mm} \\
(\mathrm{pC} \mathrm{i} / \mathrm{g}) \\
\end{array}$ & $\begin{array}{l}\text { Mixed to } 0.15 \mathrm{~m} \\
(\mathrm{pCi} / \mathrm{g})\end{array}$ \\
\hline 0 & 20 & Total Body & ${ }^{90} \mathrm{Sr}+{ }_{0}^{(d)}$ & 0.64 & 43 & 2.8 \\
\hline & 21 & Bone & ${ }^{90} S r+D$ & 0.17 & 11 & 0.73 \\
\hline & 1 & Lungs & ${ }^{137} \mathrm{Cs}+\mathrm{D} /{ }^{60} \mathrm{Co}_{0}$ & 8.6 & 580 & 38 \\
\hline & 1 & Thyroid & ${ }^{137} \mathrm{Cs}+\mathrm{D} /{ }^{60} \mathrm{Co}$ & 8.6 & 580 & 38 \\
\hline 10 & 20 & Total Body & ${ }^{90} S r+D$ & 0.42 & 28 & 1.8 \\
\hline & 21 & Bone & ${ }^{90} S r+0$ & 0.12 & 8.0 & 0.53 \\
\hline & 1 & Lungs & ${ }^{137} \mathrm{Cs}+\mathrm{D} /{ }^{60} \mathrm{Co}$ & 8.3 & 560 & 36 \\
\hline & 1 & Thyroid & ${ }^{13 /} \mathrm{Cs}+\mathrm{D} /{ }^{60} \mathrm{Co}$ & 8.3 & 560 & 36 \\
\hline 30 & 20 & Total Body & ${ }^{90} \mathrm{Sr}+\mathrm{D}$ & 0.41 & 28 & 1.8 \\
\hline & 21 & Bone & ${ }^{90} \mathrm{Sr}+\mathrm{O}$ & 0.11 & 7.4 & 0.48 \\
\hline & 1 & Lung & ${ }^{137} \mathrm{Cs}+\mathrm{D}$ & 9.1 & 610 & 40 \\
\hline & 1 & Thyroid & ${ }^{137} \mathrm{Cs}+0$ & 9.1 & 610 & 40 \\
\hline 50 & 20 & Total Body & ${ }^{90} \mathrm{Sr}+\mathrm{D}$ & 0.41 & 28 & 1.8 \\
\hline & 21 & Bone & ${ }^{90} \mathrm{Sr}+\mathrm{D}$ & 0.11 & 7.4 & 0.48 \\
\hline & 1 & Lung & ${ }^{137} \mathrm{Cs}+\mathrm{D}$ & 9.2 & 620 & 40 \\
\hline & 1 & Thyroid & ${ }^{137} C_{S}+D$ & 9.2 & 620 & 40 \\
\hline 100 & 20 & Total Body & ${ }^{90} S r+D$ & 0.42 & 28 & 1.8 \\
\hline & 21 & Bone & ${ }^{90} \mathrm{Sr}+\mathrm{D}$ & 0.12 & 8.0 & 0.53 \\
\hline & 1 & Lung & ${ }^{137} \mathrm{Cs}+\mathrm{D}$ & 8.7 & 580 & 38 \\
\hline & 1 & Thyroid & ${ }^{137} \mathrm{Cs}+\mathrm{D}$ & 8.7 & 580 & 38 \\
\hline $\begin{array}{l}\text { (a) Correspond } \\
\text { (b) The time th } \\
\text { (c) The year in } \\
\text { exposure. } \\
\text { (d) }+ \text { D means }\end{array}$ & $\begin{array}{l}\text { to an } \\
\text { contin } \\
\text { hich th }\end{array}$ & $\begin{array}{l}\text { nual dose } \\
\text { us exposur } \\
\text { maximum ar }\end{array}$ & $\begin{array}{l}50 \mathrm{mrem} / \mathrm{yr} \text { to } \\
\text { egins. } \\
1 \text { dose occurs }\end{array}$ & $\begin{array}{l}\text { ific organs of ref } \\
\text { lowing the start of }\end{array}$ & $\begin{array}{l}\text { ce. } \\
\text { tinuous }\end{array}$ & \\
\hline
\end{tabular}


For each decay time shown in Table 8.2-2, the most restrictive contamination level results from the annual dose to bone 21 years after the start of continuous exposure. This dose is controlled by ${ }^{90} \mathrm{Sr}$ and its daughter ${ }^{90} \mathrm{Y}$ in the radionuclide mixture, which are accumulated in the body by ingestion of site-grown farm products. A summary of the acceptable residual radioactive contamination levels, based on the dose to bone, is listed in Table 8.2-3.

\begin{tabular}{|c|c|c|c|}
\hline \multirow{2}{*}{$\begin{array}{l}\text { Time Exposure } \\
\text { Begins } \\
\text { Years after } \\
\text { hutdown) (b) }\end{array}$} & \multirow{2}{*}{$\begin{array}{l}\text { Acceptable Residual } \\
\text { Radioactive Surface } \\
\text { Contamination Levels } \\
\quad\left(\mu \mathrm{Ci} / \mathrm{m}^{2}\right)(\mathrm{c}) \\
\end{array}$} & \multicolumn{2}{|c|}{$\begin{array}{c}\text { Acceptable Soil } \\
\text { Contamination Levels } \\
\end{array}$} \\
\hline & & $\begin{array}{l}\text { Mixed to } 10 \mathrm{~mm} \\
(\mathrm{pC} i / \mathrm{g})\end{array}$ & $\begin{array}{l}\text { Mixed to } 0.15 \mathrm{~m} \\
(\mathrm{pCi} / \mathrm{g})\end{array}$ \\
\hline 0 & 0.17 & 11 & 0.73 \\
\hline 10 & 0.12 & 8.0 & 0.53 \\
\hline 30 & 0.11 & 7.4 & 0.48 \\
\hline 50 & 0.11 & 7.4 & 0.48 \\
\hline 100 & 0.12 & 8.0 & 0.53 \\
\hline
\end{tabular}

(a) Corresponding to an annual dose of $50 \mathrm{mrem} / \mathrm{yr}$ to the bone.

(b) The time that continuous exposure begins.

(c) Based on external exposure from contaminated ground and on internal exposure from ingestion and inhalation, as discussed in Appendix F.

\subsubsection{Acceptable Radioactive Contamination Levels on BWR Equipment}

A recent study describes a generic methodology for estimating potential radiation doses to man from recycling radioactively contaminated metals reclaimed during decommissioning nuclear facilities. (18) The methodology is demonstrated for 27 radionuclides from six recycle pathways with a contamination level of $10 \mathrm{pCi} / \mathrm{g}$. The results in Reference 18 are for a generic case and several key assumptions are made to obtain radiation dose estimates to exposed population groups. However, the methodology presented in Reference 18 should be useful in determining acceptable radioactive contamination levels for decommissioned BWR equipment. 
Release of much of the non-activated BWR equipment after decontamination could be covered by standards developed by the ANSI Committee $\mathrm{N13.12.} \mathrm{(9)} \mathrm{The}$ complexities of decontaminating equipment for public release are great and are briefly discussed in Appendix $\mathrm{N}$ of Volume 2. Because decommissioning an actual BWR requires special procedures to release equipment on a piece-by-piece basis, no further effort is made in this report to analyze equipment-release conditions.

\subsection{EXISTING GUIDANCE ON RESIDUAL RADIOACTIVE CONTAMINATION}

Existing guidance on acceptable radioactive contamination levels for unrestricted release of decommissioned nuclear facilities is found in Regulatory Guide $1.86^{(2)}$ and the draft ANSI Standard N13.12. (9) The levels reflected in these standards are listed in Tables 8.3-1 and 8.3-2. The levels shown in Tables 8.3-1 and 8.3-2 are based on instrumentation capabilities for general categories of radionuclides, while the levels developed in this study

TABLE 8.3-1. Regulatory Guide 1.86 Acceptable Surface Contamination Levels (2)

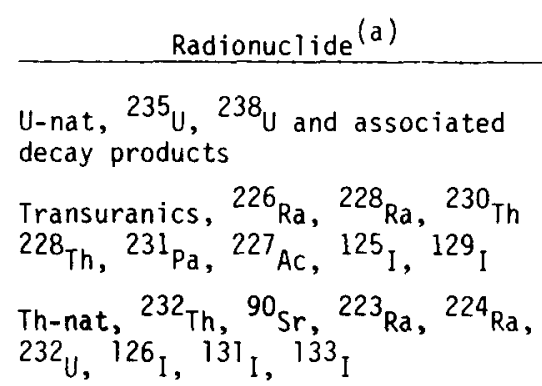

Beta-gamma emitters (nuclides with decay modes other than alpha emission or spontaneous fission) except ${ }^{90} \mathrm{Sr}$ and others noted above

$\begin{array}{lll}\text { Average }(b, c) & \text { Maximum }(b, d) & \text { Removable }{ }^{(b, e)} \\ 5000 \mathrm{dpm} x / 100 \mathrm{~cm}^{2} & 15000 \mathrm{dpm} \times / 100 \mathrm{~cm}^{2} & 1000 \mathrm{dpm} \times 100 \mathrm{~cm}^{2} \\ 100 \mathrm{dpm} / 100 \mathrm{~cm}^{2} & 300 \mathrm{dpm} / 100 \mathrm{~cm}^{2} & 20 \mathrm{dpm} / 100 \mathrm{~cm}^{2} \\ 1000 \mathrm{dpm} / 100 \mathrm{~cm}^{2} & 3000 \mathrm{dpm} / 100 \mathrm{~cm}^{2} & 200 \mathrm{dpm} / 100 \mathrm{~cm}^{2}\end{array}$

$5000 \mathrm{dpm}, / 100 \mathrm{~cm}^{2} \quad 15000 \mathrm{dpm}, / 100 \mathrm{~cm}^{2}, 1000 \mathrm{dpm}, 1 / 100 \mathrm{~cm}^{2}$

(a) Where surface contamination by both alpha- and beta-ganma-emitting nuclides exists, the limits established for alpha- and beta-gamma-emitting nuclides apply independently.

(b) Used in this table, dpm (disintegrations per minute) means the rate of emission by radioactive material as determined by correcting the counts per minute observed by an appropriate detector for background, efficiency, and geometric factors associated with the instrumentation.

(c) Measurements of average contaminant should not be averaged over more than $1 \mathrm{~m}^{2}$. For objects of less surface area, the average should be derived for each object.

(d) The maximum contamination level applies to an area of not more than $100 \mathrm{~cm}^{2}$

(e) The amount of removable radioactive material per $100 \mathrm{~cm}^{2}$ of surface area should be determined by wiping that area with dry filter or soft absorbent paper, applying moderate pressure, and assessing the amount of radioactive material on the wipe with an appropriate instrument of known efficiency. When removable contamination on objects of less surface area is determined, the pertinent levels should be reduced proportionally and the entire surface wiped. 
TABLE 8.3-2. ANSI N13.12 Surface Contamination Limits (9)

Radionuclide ${ }^{(a)}$

Group 1:

Nuclides for which the nonoccupational $\mathrm{MPC}_{\mathrm{a}}(\mathrm{b})$ is $2 \times 10^{-13} \mathrm{Ci} / \mathrm{m}^{3}$ or less or for which the nonoccupational $\mathrm{MPC}_{\mathrm{w}}(\mathrm{c})$ is $2 \times 10^{-7} \mathrm{Ci} / \mathrm{m}^{3}$ or less; includes Ac-227;

Am-241, -242m, -243; Cf-249, -250, -251, -252; Cm-243, $-244,-245,-246,-247,-248 ; \mathrm{I}-125, \mathrm{I}-129 ; \mathrm{Np}-237$;

$\mathrm{Pa}-231 ; \mathrm{Pb}-210 ; \mathrm{Pu}-238,-239,-240,-242,-244$; Ra-226, -228 ; Th-228, -230 .

Group 2:

Those nuclides not in Group 1 for which the nonoccupational $\mathrm{MPC}_{\mathrm{a}}$ is $1 \times 10^{-12} \mathrm{Ci} / \mathrm{m}^{3}$ or for which the nonoccupationa) $M P C_{W}$ is $1 \times 10-6 \mathrm{Ci} / \mathrm{m}^{3}$ or less; includes $\mathrm{Es}-254$;

Fm-256; I-126, -131, -133; Po-210; Ra-223; Sr-90; Th-232; U-232.

Group 3:

Those nuclides not in Group 1 or Group 2.

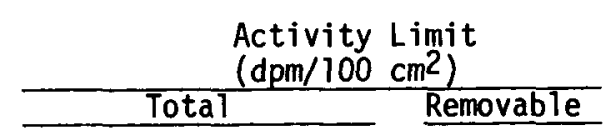

Nondetectable ${ }^{(d)}$

$$
2000(\alpha)^{N o n d e t e c t a b l e} e^{(\beta, \gamma)^{(e)}}
$$

\footnotetext{
(a)Values presented here are obtained from 10 CFR Part 20. The most limiting of all given MPC values (e.g., soluble vs. insoluble) are to be used. In the event of the occurrence of mixtures of radionuclides, the fraction contributed by each constituent of its own limit shall be determined and the sum of the fractions must be less than 1 .

(b) $M P C_{a}$ : maximum permissible concentration in air applicable to continuous exposure of members of the public as published by or derived from an authoritative source such as NCRP., ICRP or NRC (10 CFR Part 20 Appendix B Table 2, Column 1).

(c) $M P C_{W}$ : maximum permissible concentration in water applicable to members of the public.

(d) The instrument utilized for this measurement shall be calculated to measure at least $100 \mathrm{pCi}$ of any Group-l contaminants uniformly spread over $100 \mathrm{~cm}^{2}$.

(e) The instrument utilized for this measurement shall be calibrated to measure at least $1 \mathrm{nCi}$ of any Group-2 beta or gamma contaminants uniformly spread over an area equivalent to the sensitive area of the detector. NOTE: Direct survey for unconditional release should be performed in areas where the background is $\leq 100 \mathrm{c} / \mathrm{m}$. When the survey must be performed in a background exceeding $100 \mathrm{c} / \mathrm{m}$, it may be necessary to use the indirect survey method to provide the additional sensitivity required.
}

using the pathways analysis approach are based on an assumed maximum annual dose of $50 \mathrm{mrem}$. Using the maximum annual dose as the general basis for determining acceptable radioactive contamination levels permits the necessary flexibility for considering the various radionuclide mixtures expected at decommissioned nuclear facilities. 


\subsection{SUMMARY OF EXAMPLE ACCEPTABLE CONTAMINATION LEVELS}

The calculated acceptable levels of radioactivity reported in Tables 8.2-2 and 8.2-3 are summarized in Table 8.4-1. In this table, the acceptable residual radioactivity levels for the facility are characterized as surface contamination. For the site, the surface contamination values are presented along with mass contamination values, in units of radioactivity per unit mass. The conversion from surface to mass contamination units is done assuming that the contamination is mixed in soil to a depth of $10 \mathrm{~mm}$ before plowing and to a depth of $0.15 \mathrm{~m}$ after.

TABLE 8.4-1. Summary of the Calculated Acceptable Residual Radioactive Contamination Levels for the Reference BWR Facility and Site

\begin{tabular}{|c|c|c|c|c|c|}
\hline & \multirow{3}{*}{$\begin{array}{c}\text { Time Exposure } \\
\text { Begins } \\
\text { (Years after } \\
\text { Shutdown (a) } \\
\end{array}$} & \multirow[b]{3}{*}{$\begin{array}{l}\text { Limiting } \\
\text { Organs } \\
\end{array}$} & \multicolumn{3}{|c|}{$\begin{array}{l}\text { Acceptable Residual Contamination Levels } \\
\text { Corresponding to an Annual Dose of } 50 \mathrm{mrem} / \mathrm{yr}\end{array}$} \\
\hline & & & Surface & Soil Cont & mination \\
\hline & & & $\frac{\text { Contamination }}{\left(\mu \mathrm{Ci} / \mathrm{m}^{2}\right)}$ & $\frac{\text { Mixed to } 10 \mathrm{~mm}}{(\mathrm{pCi} / \mathrm{g})}$ & $\frac{\text { Mixed to } 0.15 \mathrm{~m}}{(\mathrm{pCi} / \mathrm{g})}$ \\
\hline \multirow[t]{2}{*}{ BWR Facility (b) } & 0 & Lungs & $5.5 \times 10^{-1}$ & -- & -- \\
\hline & 100 & Bone & $8.2 \times 10^{-1}$ & --- & -- \\
\hline \multirow[t]{2}{*}{ BWR Site } & 0 & Bone & $1.7 \times 10^{-1}$ & $1.1 \times 10^{1}$ & $7.3 \times 10^{-1}$ \\
\hline & 100 & Bone & $1.2 \times 10^{-1}$ & $8.0 \times 10^{0}$ & $5.3 \times 10^{-1}$ \\
\hline
\end{tabular}

(a)The time that continuous exposure begins.

(b) In the facility, a determination of acceptable surface radioactive contamination levels, based on the mixture of the radionuclides, is assumed to be used to help determine the necessary decommissioning procedures.

In summary, in the BWR facility, the acceptable contamination levels are dominated by external exposure: from ${ }^{60} \mathrm{Co}_{0}$ at short decay times and from

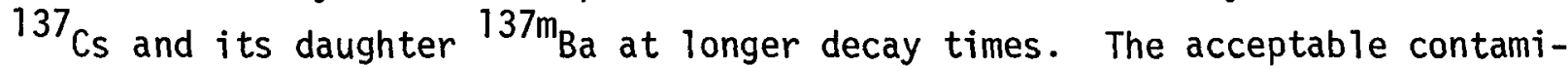
nation levels increase with time as the contribution of ${ }^{60}$ Co decreases (because of radioactive decay) relative to the contribution of the longer-lived and

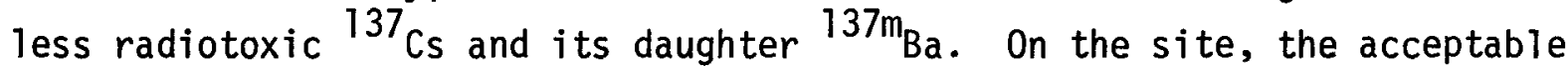
contamination levels are dominated by the dose to bone from ${ }^{90} \mathrm{Sr}$ and its short-lived daughter ${ }^{90} \mathrm{Y}$. The dominant exposure pathway is the ingestion of site-grown farm products. The acceptable radioactive contamination level 
decreases with time, reflecting the radioactive decay of short-lived fission products in the initial radionuclide mixtures.

\subsection{RADIATION DETECTION CAPABILITIES}

Federal regulations require environmental monitoring of LWR nuclear power stations for radioactivity released during normal operations. (19) other regulations $(20)$ require that a licensee conduct surveys of radiation levels or concentrations of radioactive contaminants to ensure compliance with 10 CFR Part 20 limits. Specifically, Paragraph 20.1(c) of 10 CFR Part 20 states that every reasonable effort should be made by the licensee to maintain radiation exposure "as low as reasonably achievable." Guidance on environmental sampling techniques to help meet these regulations is found in Regulatory Guides, (21-23) and in procedures developed by the DOE Environmental Measurements Laboratory. (24)

To ensure compliance with these regulations, personnel at operating BWRs routinely monitor both effluent and environmental levels of radioactivity. With the existence of annually recorded monitoring data and established sampling and laboratory measurement techniques, the ability already exists to identify radioactive species and to verify the radioactive contamination levels that correspond to the calculated acceptable contamination levels listed in Tables 8.2-1 and 8.2-2. A general discussion of environmental regulations or guidance and definition of the Lower Limit of Detection (LLD) for common laboratory methods is presented in this section. The laboratory methods discussed can be used to analyze samples from either the BWR facility or its site.

The LLD is defined in Regulatory Guide 4.16 as being the smallest concentration of radioactive material in a sample that has a $95 \%$ probability of being detected above the system background. (25) For a particular counting system, the LLD is mathematically expressed by:

$$
L L D=\frac{4.66 S_{b}}{3.7 \times 10^{4} E V Y \exp (-\lambda \Delta t)}
$$


where:

LLD - the lower limit of detection, $\mu \mathrm{Ci} / \mathrm{ml}$

4.66 - a factor relating the $95 \%$ confidence limit of a one-sided confidence factor for measurements where the background counting time equals the sample counting time

$\mathrm{S}_{\mathrm{b}}$ - the standard deviation of the instrument background counting rate, counts/second

$3.7 \times 10^{4}$ - the number of disintegrations per second per $\mu \mathrm{Ci}$

E the detector counting efficiency, counts observed per disintegration

V the sample volume, me

$Y$ - the fractional radiochemical yield; only applies when a radiochemical separation is performed on the sample

$\lambda$ - the radioactive decay constant for the particular radionuclide, seconds $^{-1}$

$\Delta t$ - the time elapsed between sample collection and counting.

The values of these parameters should be based on the actual characteristics of the system used, not on theoretically predicted values.

The LLD varies with the type of instrumentation used, the mixture of radionuclides in the sample, the counting time selected, the sample size, and the counting geometry. Using sodium iodide (NaI) detectors, the LLD levels for samples containing single or simple parent-daughter radionuclide pairs are listed in Table 8.5-1, (23) together with the example acceptable residual soil contamination levels for reference radionuclide inventory 6 (contamination mixed in the top $10 \mathrm{~mm}$ of soi1). Comparison of the values in the last two columns of the table shows that only ${ }^{60} \mathrm{Co},{ }^{90} \mathrm{Sr}$, and ${ }^{137} \mathrm{Cs}$ could be readily detectable using $\mathrm{NaI}$ detector systems. Laboratory analysis with more sensitive equipment would be necessary to determine the relative radioactivity of the other radionuclides for use in the pathways analysis. 
TABLE 8.5-1. Comparison of Lower Limits of Detection for NaI Systems with Calculated Example Acceptable Residual Soil Contamination Levels, for Selected Radionuclides(a)

\begin{tabular}{|c|c|c|c|c|}
\hline \multirow[b]{2}{*}{ Analys is } & \multicolumn{3}{|c|}{ Lower Limit of Detection (b) } & \multirow{2}{*}{$\begin{array}{c}\text { Example Acceptable } \\
\text { Residual Soil } \\
\text { Contamination Level } \\
\text { (pCi/kg, Dry) } \\
\end{array}$} \\
\hline & $\begin{array}{l}\text { Water } \\
(\mathrm{pCi} / \mathrm{l})\end{array}$ & $\begin{array}{c}\text { Vegetation } \\
(\mathrm{pCi} / \mathrm{kg} \text {, Wet })\end{array}$ & $\begin{array}{r}\text { Soil } \\
\text { (pCi/kg, Dry) }\end{array}$ & \\
\hline $3_{H}($ HTO $)$ & 300 & $300^{(d)}$ & $\ldots(e)$ & $\ldots--(f)$ \\
\hline${ }^{54} \mathrm{Mn}$ & 15 & 150 & 50 & 40 \\
\hline $58,60 \mathrm{Co}_{\mathrm{O}}$ & 15 & 150 & 50 & 540 \\
\hline${ }^{65} \mathrm{Zn}$ & 30 & 300 & 100 & 3.2 \\
\hline${ }^{89} \mathrm{Sr}(\mathrm{c})$ & 10 & 10 & 150 & 120 \\
\hline${ }^{90} \mathrm{Sr}(\mathrm{c})$ & 2 & 2 & 30 & 2800 \\
\hline${ }^{95} \mathrm{Zr}-\mathrm{Nb}$ & 10 & 150 & 100 & 0.75 \\
\hline${ }^{106} \mathrm{Ru}-\mathrm{Rh}$ & 10 & 150 & 100 & 7.8 \\
\hline $129_{\mathrm{I}}(\mathrm{c})$ & 2 & 10 & $-\ldots(e)$ & \\
\hline $131_{I}(c)$ & 0.4 & 2 & $\ldots(e)$ & 5.2 \\
\hline 134,137 Cs & 15 & 150 & 100 & 4000 \\
\hline $140 \mathrm{Ba}-\mathrm{La}$ & 15 & 150 & 100 & 34 \\
\hline$u^{(c)}$ & 2 & 50 & 30 & $-\ldots(f)$ \\
\hline Pu-Alpha $(c)$ & 0.01 & 5 & 1 & $---(f)$ \\
\hline
\end{tabular}

(a) This table is based on similar values given in Regulatory Guide 4.8 , (23) with adjustments and additions reflecting current experience at a commercial radioanalytical laboratory.

(b) The normal Lower Limit of Detection is defined in HASL 300, Appendix D (Rev. 8/74), (24) at the 95\% confidence level. The LLD for radionuclides analyzed by gamma spectrometry varies according to the number of radionuclides encountered in environmental samples.

(c) Assumed dose 1 imit is $50 \mathrm{mrem} / \mathrm{yr}$, contamination mixed with top $10 \mathrm{~mm}$ of soil.

(d) After chemical extraction.

(e) Indicates that no data i's available for these radionuclides in dry soil samples.

(f) Indicates that the radionuclide is not included in reference radionuclide inventory 6 . 
It should be noted that the LLDs for mixtures of radionuclides (as postulated for reference radionuclide inventory 6) would be expected to be significantly higher than those listed in Table 8.5-1 due to possible interferences between gamma rays of similar energy. Thus, quantitative measurements at these concentrations are far more difficult.

To overcome the interference problem it may be necessary to utilize more sophisticated detectors such as germanium-lithium (Ge[Li]) semiconductors. Typical values of the LLD for a Ge(Li) detection system are given in Table 8.5-2, together with example acceptable residual soil contamination levels (contamination mixed in the top $10 \mathrm{~mm}$ of soil). The LLD values given are for samples consisting of air filters containing mixtures of fission products. The sample postulated for the acceptable residual level values has a volume of soil $50 \mathrm{~mm}$ in diameter and $25 \mathrm{~mm}$ thick. Comparison of the LLDs with the example acceptable residual levels in Table $8.5-2$ shows that few radionuclides $\left({ }^{60} \mathrm{Co},{ }^{137} \mathrm{Cs}\right)$ can be successfully measured at levels corresponding to a dose of $50 \mathrm{mrem} / \mathrm{yr}$ to the maximum-exposed individual. However, if the relative composition of the mixture of radionuclides can be satisfactorily determined by careful laboratory means, and if this mixture is constant at all locations, the two radionuclides that can be measured at the example acceptable level can serve to monitor compliance with the $50 \mathrm{mrem} / \mathrm{yr}$ dose limitation. 
TABLE 8.5-2. Comparison of Lower Limits of Detection for a Typical Ge(Li) System with Calculated Example Acceptable Residual Soil Contamination Levels, for a Mixture of Fission Products

\begin{tabular}{|c|c|c|c|c|c|}
\hline Radionucl ide & $\begin{array}{r}G e(L i) L L D \\
\operatorname{dpm} / \text { Sample }(a, b)\end{array}$ & $\begin{array}{l}\text { Example Acceptable } \\
\text { Residual Soil } \\
\text { Contamination Leyel } \\
\text { dpm/Sample(a,c) } \\
\end{array}$ & Radionuclide & $\begin{array}{c}G e(L i) \text { LLD } \\
\text { dpm/Sample }(a, b) \\
\end{array}$ & $\begin{array}{c}\text { Example Acceptable } \\
\text { Residual Soil } \\
\text { Contamination Level } \\
\text { dpm/Sample(a,c) } \\
\end{array}$ \\
\hline${ }^{7} \mathrm{Be}$ & 68 & $\ldots(d)$ & ${ }^{106} \mathrm{Ru}$ & 68 & 0.75 \\
\hline${ }^{54} \mathrm{Mn}$ & 4 & 3.9 & ${ }^{125} \mathrm{Sb}$ & 21 & 0.0030 \\
\hline${ }^{57} \mathrm{Co}$ & 3 & --- & $131_{I}$ & 7 & 0.51 \\
\hline${ }^{58} \mathrm{Co}$ & 4 & 0.33 & ${ }^{137} \mathrm{Cs}$ & 7 & 390 \\
\hline${ }^{60} \mathrm{Co}$ & 5 & 54 & ${ }^{140} \mathrm{Ba}$ & 5 & 3.3 \\
\hline${ }^{65} \mathrm{Zn}$ & 9 & 0.32 & ${ }^{141} \mathrm{Ce}$ & 5 & 0.084 \\
\hline $88 y$ & 5 & -- & ${ }^{144} \mathrm{Ce}$ & 24 & 0.24 \\
\hline${ }^{95} \mathrm{zr}$ & 11 & 0.075 & ${ }^{147} \mathrm{Nd}$ & 59 & $\cdots$ \\
\hline${ }^{103} \mathrm{Ru}$ & 8 & -- & & & \\
\hline
\end{tabular}

(a) The sample was in a 50-mm-diameter by 25-mm-deep sample-holder.

(b) For a detector efficiency of $1.2 \%$ for $137 \mathrm{Cs}$ and a counting time of 1000 minutes.

(c) Assumed dose limit is $50 \mathrm{mrem} / \mathrm{yr}$, contamination mixed with top $10 \mathrm{~mm}$ of soil.

(d) Indicates that the radionuclide is not included in reference radionuclide inventory 6 . 


\section{REFERENCES}

1. K. J. Schneider and C. E. Jenkins, Technology, Safety and Costs of Decommissioning a Reference Nuclear Fuel Reprocessing Plant, NUREG-0278, Section 6, Prepared by Pacific Northwest Laboratory for the U.S. Nuclear Regulatory Commission, October 1977.*

2. U.S. NRC, Termination of Operating Licenses for Nuclear Reactors, Regulatory Guide 1.86, June 1974.

3. U.S. NRC, Guidelines for Decontamination of Facilities and Equipment Prior to Release for Unrestricted Use or Termination of Licenses for By-product, Source or Special Nuclear Material, November 1976.

4. U.S. Code of Federal Regulations, Title 49, Part 173, "Transportation," Superintendent of Documents, GP0, Washington, DC, 20555, 1976.

5. U.S. ERDA, "Prevention Control and Abatement of Air and Water Pollution," U.S. ERDA Manual, Chapter 0510, April 2, 1975.

6. J. W. Healy, A Proposed Interium Standard for Plutonium in Soils, LA-5483-MS, Los ATamos Scientific Laboratory, Los ATamos, NM, January 1974.

7. C. E. Guthrie and J. P Nichols, Theoretical Possibilities and Consequences of Major Accidents in 233 $\mathrm{U}$ and $239 \mathrm{Pu}$ Fuel Fabrication and Radioisotopes Processing Plants, ORNL-3441, Oak Ridge National Laboratory, Oak Ridge, TN 37380, Apri7 1964.

8. A. J. Hazle and B. L. Crist, Colorado's Plutonium-Soil Standard, Colorado Department of Health, Occupational and Radiological Health Division Denver, CO, 1975.

9. ANSI Standard N13.12, Control of Radioactive Surface Contamination on Materials, Equipment and Facilities to be Released for Uncontrolled Use, Published for ANSI National Trial and Use in August 1978.

10. R. I. Smith, G. J. Konzek and W. E. Kennedy, Jr., Technology, Safety and Costs of Decommissioning a Reference Pressurized Water Reactor Power Station, NUREG/CR-0130, Section 8, Prepared by Pacific Northwest Laboratory for the U.S. Nuclear Regulatory Commission, June 1978. **

11. C. E. Jenkins, E. S. Murphy and K. J. Schneider, Technology, Safety and Costs of Decommissioning a Reference Small Mixed 0xide Fuel Fabrication Plant, NUREG/CR-0129, Section 8, Prepared by Pacific Northwest Laboratory for the U.S. Nuclear Regulatory Commission, February 1979. **

12. "Recommendations of the International Commission on Radiological Protection," ICRP Publication 9, Pergamon Press, London, 1966.

ॠAvailable for purchase from the National Technical Information Service, Springfield, Virginia 22161.

** Available for purchase from the NRC/GPO Sales Program, U.S. Nuclear Regulatory Commission, Washington, D.C. 20555, and the National Technical Information Service, Springfield, Virginia 22161. 
13. Surgeon General, U.S. Public Health Service, Surgeon General's Guidelines, "Use of Uranium Mill Tailings for Constructive Purposes," Hearings Before the Subcommittee on Raw Materials of the Joint Committee on Atomic Energy, October 28 and 29, 1971, pp. 52-54, 1971.

14. Code of Federal Regulations, Title 10, Part 50, Appendix I, "Licensing of Production and Utilization Facilities," Superintendent of Documents, GP0, Washington, DC, 20555, 1976.

15. U.S. Environmental Protection Agency, Proposed Guidance on Dose Limits for Persons Exposed to Transuranium Elements in the General Environment, EPA 520/4-77-016, September 1977.

16. U.S. Code of Federal Regulations, Title 40, Part 190, "Environmental Radiation Protection Standards for Nuclear Power Operations," Superintendent of Documents, GPO, Washington DC, 20555, January 1977.

17. U.S. NRC, Radioactive Materials Released from Nuclear Power Plants (1975), NUREG-0218, March 1977.*

18. F. R. O'Donnell et a1., Potential Radiation Dose to Man from Recycle of Metals Reclaimed from a Decommissioned Nuclear Power Plant, NUREG/CR-0134, ORNL/NUREG/TM-215, Prepared by Oak Ridge National Laboratory for the U.S. Nuclear Regulatory Commission, December 1978.**

19. U.S. Code of Federal Regulations, Title 10, Part 50, Appendix A, "Licensing of Production and Utilization Facilities," General Design Criteria 64, Superintendent of Documents, GPO, Washington, DC 20555, 1976.

20. U.S. Code of Federal Regulations, Title 10, Part 20, "Standards for Protection Against Radiation," Superintendent of Documents, GPO, Washington, DC 20555, 1978.

21. Directorate of Regulatory Standards, Measurements of Radionuclides in the Environment, Sampling and Analysis of Plutonium in Soil, Regulatory Guide 4.5, U.S. Nuclear Regulatory Commission, Washington, DC, May 1974.

22. Directorate of Regulatory Standards, Measurements of Radionuclides in the Environment, Strontium-89 and Strontium-90 Analysis, Regulatory Guide 4.6, U.S. Nuclear Regulatory Commission, Washington, DC, May 1974.

23. Directorate of Regulatory Standards, Environmental Technical Specifications for Nuclear Power Plants, Regulatory Guide 4.8, U.S. Nuclear Regulatory Commission, Washington, DC, December 1975.

24. J. H. Harley, Ed., HASL Procedures Manual, HASL-300, Supplement 5, Health and Safety Laboratory, HASL-300 Rev., New York, NY, August 1977.

*Available for purchase from the National Technical Information Service, Springfield, Virginia 22161.

**Available for purchase from the NRC/GPO Sales Program, U.S. Nuclear Regulatory Commission, Washington, D.C. 20555, and the National Technical Information Service. Springfield, Virginia 22161. 
25. Directorate of Regulatory Standards, Measuring, Evaluating, and Reporting Radioactivity in Releases of Radioactive Materials in Liquid and Airborne Effluents from Nuclear Fuel Processing and Fabrication Plants, Regulatory Guide 4.16, U.S. Nuclear Regulatory Commission, Washington, DC, March 1978.

26. J. H. Harley, Ed., HASL Procedures Manual, HASL-300, Supplement 2, Health and Safety Laboratory, New York, NY, August 1974. 
1

0 
CHAPTER 9

\section{DECOMMISSIONING ACTIVITIES AND MANPOWER REQUIREMENTS}

This chapter contains information concerning the activities and manpower requirements for the three different approaches to decommissioning the reference BWR: 1) immediate dismantlement, 2) passive safe storage, and 3) entombment. Information on deferred dismantlement is also included. The information presented here is a summary of the appropriate sections of Appendices $H, I, J$ and $K$ in Volume 2, which, respectively, contain the generic decommissioning information and the details for the three decommissioning modes. The three modes are described and discussed in more detail in Chapter 4.

\subsection{IMMEDIATE DISMANTLEMENT ACTIVITIES AND MANPOWER REQUIREMENTS}

Immediate dismantlement is the decommissioning mode that leads to the earliest termination of the utility's nuclear license. Compared to the other two decommissioning modes, immediate dismantlement results in a greater occupational radiation dose and a greater cost in the first few years after final reactor shutdown. Planning and preparation activities, dismantlement activities, and the schedule and manpower requirements for immediate dismantlement are presented in this section.

\subsubsection{Planning and Preparation Activities}

Immediate dismantlement of the reference BWR is a complex undertaking, and its success depends greatly on good planning and completion of preparatory work before final reactor shutdown. Planning and preparation for immediate dismantlement is accomplished during the 2 years prior to final reactor shutdown.

Planning and preparation activities include the following:

- satisfying regulatory requirements

- gathering and analyzing data

- developing detailed work plans and procedures 
- designing, procuring, and testing special equipment

- selecting and training staff

- selecting specialty contractors

- removing accumulated spent fuel and unneeded spent fuel storage racks

- installing additional HEPA filters.

These activities are discussed in the following subsections.

\subsubsection{Satisfying Regulatory Requirements}

The current status of NRC regulatory requirements is presented in Chapter 5. Activities undertaken to satisfy these regulatory requirements are described in this subsection.

The major requirements are: 1) providing the necessary documentation for amending the facility operating license to "possession-only" status and 2) obtaining an NRC dismantling order.

In requesting an amended license, the licensee must provide:

- a description of the current facility status

- an inventory of the onsite radioactive materials

- a description of the proposed decommissioning activities

- a description of the proposed measures to prevent criticality and to minimize radioactive releases

- any proposed changes to the technical specifications (e.g., deletion of specifications relating solely to plant operation)

- safety analyses of both the proposed activities and the proposed specification changes.

An NRC dismantling order is required for immediate dismantlement. The request for such an order must include a dismantlement plan providing:

- a description of the ultimate facility status

- a description of the dismantling activities (including radioactive material disposal and site decontamination) and the associated environmental and safety precautions 
- a safety analysis of the dismantlement and any resultant releases

- a safety analysis of the plant in its ultimate status.

In addition to the aforementioned documentation, the licensee must submit a radioactive waste handling plan, a quality assurance plan, an environmental report, and security and safeguards plans. Updated information concerning the financial qualification of the licensee may also be required (see Section 5.1 of Chapter 5 for further details).

\subsubsection{Gathering and Analyzing Data}

A large body of data is gathered and analyzed during the planning and preparation phase of decommissioning. These data help satisfy the regulatory requirements discussed in the previous subsection, particularly the inventory of radioactive materials and the various safety analyses. In addition, they provide the bases for planning the decommissioning tasks and for selecting the appropriate methods and equipment.

Included in this activity is a comprehensive survey of radiation dose rates and contamination levels in the facility. This survey, taken after final reactor shutdown, provides information for determining decontamination and temporary shielding requirements. It also provides initial data on radiation dose rates likely to be encountered during the various decommissioning tasks.

\subsubsection{Developing Detailed Work Plans and Procedures}

Detailed work plans and procedures are developed based on the information gathered during data gathering and resultant analyses and provided to the NRC with the license amendment and dismantling order requests. These detailed plans and procedures contain all the information required to actually carry out the decommissioning tasks. They address the following items:

- decommissioning methods

- schedules and sequences of events

- radioactive waste management

- contamination control 
- radiological and industrial safety

- equipment requirements.

Quality assurance, security, and environmental constraints are also considered. The plans and procedures cover all aspects of the decommissioning project.

\subsubsection{Designing, Procuring, and Testing Special Equipment}

Any special equipment required to complete the decommissioning project is identified during planning and preparation. Designs and specifications are prepared for each item required. When the item is procured, it is inspected to verify that it meets specifications and complies with applicable $Q A$ and safety requirements. It is then tested to ensure that it performs as required. The testing also serves to train personnel in the use of the equipment and to provide pertinent data on its operation.

\subsubsection{Selecting and Training Staff}

At the start of planning and preparation, a decommissioning organization is created within the utility. Staffing requirements are identified, and critical positions are filled with key engineering and operating personnel. The personnel are trained as required to fulfill their roles in the organization; special emphasis is given to the use of new and unique equipment and procedures. Organization of the decommissioning staff is discussed in detail later in this section.

\subsubsection{Selecting Specialty Contractors}

During planning and preparation, the decommissioning planning staff identifies and selects the specialty contractors required to decommission the facility. These contractors perform unique services outside of the expertise or capability of the utility staff. After the needs are identified, contractors are invited to bid on the required work packages. Contractual agreements are concluded prior to the start of the actual decommissioning, if possible, to ensure the uninterrupted completion of the project. Specialty contractor requirements are also discussed later in this section. 


\subsubsection{Removing Accumulated Spent Fuel and Unneeded Spent Fuel Storage Racks}

Any spent fuel stored from previous refueling activities is removed from the spent fuel storage pool and shipped to a repository. In addition, for immediate dismantlement, the spent fuel storage racks in excess of those required for final reactor defueling are removed and shipped offsite. By removing these excess items prior to the start of the actual decommissioning, extra space is made available in the spent fuel storage pool for interim storage and packaging of activated materials removed from the reactor vessel.

\subsubsection{Installing Additional HEPA Filters}

Prior to the start of the actual decommissioning tasks, HEPA filters are installed outboard of the blowers in the HVAC exhaust systems of the Reactor Building and the Turbine Generator Building. (The Radwaste and Control Building HVAC system is already equipped with HEPA filters, see Section C.4.3 of Appen$\operatorname{dix} C$ in Volume 2). These filters are installed to lessen the atmospheric release of airborne radioactivity generated during immediate dismantlement, because many of the tasks are expected to generate airborne contamination that exceeds that produced during normal plant operation.

\subsubsection{Immediate Dismantlement Activities}

The activities and requirements for immediate dismantlement of the reference BWR are discussed in this subsection, including decontamination, disassembly and disposal, quality assurance, environmental surveillance, specialty contractors, and essential systems and services.

\subsubsection{Decontamination}

At final reactor shutdown, significant radioactive contamination is present on the surfaces of process systems and equipment. Decontamination is necessary to remove the bulk of this radioactive contamination from selected systems and components. The objectives of the decontamination effort are twofold: first, to reduce the radiation levels throughout the facility in order to minimize personnel exposure during disassembly; and second, to attempt to 
clean as much material as possible to unrestricted levels, thereby permitting salvage of valuable material and reducing the quantities of material that must be packages and shipped to a disposal site.

In this study, however, for several reasons, no credit is taken for the potential effectiveness of the decontamination effort in achieving reductions of the radioactive contamination to levels that permit unrestricted release of the material. First, the effectiveness of the methods has not been demonstrated for the type of large-scale application postulated here. Second, the levels of residual radioactivity that are permitted on material that is returned to the commercial stream are not defined by any regulation. Third, depending on the acceptable limits of residual radioactivity, the costs of adequate radiation surveys and possible repeated cleanings to achieve releasability may be greater than the salvage value of the released material.

The two methods used for system decontamination of the reference BWR are:

- chemical decontamination (recirculatory and single-pass methods)

- water jet contamination.

Decontamination methods are discussed in detail in Section G.1 of Appendix G in Volume 2. The advantages and disadvantages of chemical decontamination methods that can be used for decontaminating the reference BWR are shown in Table G.1-1 in Appendix G. For systems to be decontaminated by recirculation of the decontaminating solution through the system, a 5 wt\% EDTA/citrox solution is assumed used. A $10 \mathrm{wt} \%$ phosphoric acid solution is assumed used on those systems to be decontaminated by a single pass of the decontaminating solution. Systems to be chemically decontaminated are selected on the following bases in descending order of importance:

- expected contact radiation dose rate after draining (systems or components with expected dose rates of $<15 \mathrm{mR} / \mathrm{hr}$ are not considered)

- flow capabilities

- operational heating capabilities

- size. 
Three categories of systems and components in the reference BWR that are selected for chemical decontamination are: 1) six reactor piping systems, recirculatory (some with jumpers); 2) the three contaminated drain piping systems, single-pass; and 3 ) the liquid and solid radwaste processing systems, recirculatory (using mobile chemical decontamination units).

The six reactor piping systems to be decontaminated include the reactor water recirculation system, the reactor water cleanup system, the residual heat removal system, the low-pressure core spray system, and the fuel pool cooling and cleanup system. The three contaminated drain piping systems include the miscellaneous waste (radioactive) system, the equipment drain (radioactive) system, and the floor drain (radioactive) system. The liquid radwaste processing systems are extensions of the drain systems and have identical names, and the solid radwaste system is termed the process waste (radioactive) system.

Before dismantlement, the water jet is used to decontaminate the following:

- suppression pool

- reactor well pool

- dryer and steam separator storage pool

- spent fuel storage pool

- internal surfaces of the condensate storage tanks

- internal surfaces of the main condenser

- external surfaces of the contaminated components in the liquid and solid radwaste system.

In general, water-jet decontamination proceeds concurrently with draining the contaminated water from tanks and pools.

\subsubsection{Disassembly and Disposal}

Disassembly of the reference BWR is started after the reactor is defueled, systems and components are decontaminated, and temporary shielding is installed where a comprehensive radiation survey indicates the need. 
The exact component removal sequence within a given system or locality is dictated by the component's accessibility and the anticipated personnel exposures during removal. When possible, items that contribute significantly to the general level of exposure in the work area are either removed first or are temporarily shielded while the work goes on. Systems are unbolted at flanges when possible and cut into manageable sections, using an appropriate cutting device (plasma-arc torch, arc saw, oxyacetylene torch, or power hack saw). Piping is cut into lengths compatible with standard shipping boxes. Similarly, tanks and pool liners are cut into plate segments appropriately sized. In this study, all initially contaminated materials are assumed to remain contaminated to greater than unrestricted use levels, even after decontamination, and are packaged for disposal as radioactive waste.

Packaging of radioactive materials for disposal is accomplished in accordance with DOT regulations published in 49 CFR Parts 173 through 178, and with NRC regulations published in 10 CFR Part 71 and Regulatory Guide 7.1. Containers are lined with shielding material when necessary to reduce surface dose rates to acceptable levels. Some items such as heat exchangers may have openings welded shut and shipped using the outer shell of the exchanger as the container.

Shipping of packaged contaminated materials from the facility to a waste burial site is accomplished using trucking companies that specialize in transporting special materials. The volume of materials to be transported and the number of shipments required are estimated in Section I.3 of Appendix I.

The reactor vessel internals are removed from the reactor vessel with the vessel and the reactor well filled with water. Components welded in place in the reactor vessel are cut loose using an underwater plasma-arc torch. These components are moved under water from the vessel to the dryer and separator storage pool. There they are cut (with a plasma-arc torch or an arc saw) into pieces that fit into DOT-approved shipping containers for transport to the disposal site. The neutron-activated components are placed in B3 shielded shipping containers and the contaminated materials are packaged in standard shipping boxes, $1.2 \mathrm{~m} \times 1.2 \mathrm{~m} \times 2.4 \mathrm{~m}$, or in specially made boxes. The plasmaarc torch that is used to cut the core shroud into packageable-height rings is guided by a remotely controlled manipulator installed in the reactor vessel. 
The reactor vessel is remotely cut into rings for removal to the dryer and separator storage pool. Circumferential cuts of the vessel wall are made in air with an oxyacetylene torch guided by the manipulator. While a ring is being cut from the vessel, the vessel is filled with water to a level just below the circumferential cut line. The rings are sectioned under water in the dryer and separator storage pool into pieces that fit into appropriate shipping containers.

Small contaminated equipment is removed and packed in standard shipping boxes. Large contaminated equipment having no external smearable contamination is sealed by welding steel plates over all openings. Such equipment is then shipped to a burial ground, using the outer shell as the packaging. Contaminated equipment that is too large to be shipped as a unit is cut up either into segments that will fit into standard shipping boxes or into segments that can be sealed with welded steel plates.

Contaminated concrete is removed using a concrete spaller, which is assumed to remove a surface layer about $50 \mathrm{~mm}$ thick. The rubble is packaged in standard shipping boxes for disposal.

Techniques for disassembly of the reference BWR are described generically in Appendix G. A detailed discussion of the dismantlement of the reference BWR is given in Section I.I of Appendix I.

\subsubsection{Quality Assurance}

An extensive quality assurance program is carried on throughout the decommissioning effort to assure that all applicable regulations are met, to assure that the work is performed according to plan, to assure that the work does not endanger public safety, and to assure the safety of the decommissioning staff.

During the 2-year period prior to shutdown, QA personnel are active in the following areas:

- reviewing decommissioning plans for quality assurance involvement

- preparing inspection/test procedures as work plans are developed 
- reviewing designs of test equipment for quality input

- ordering any inspection/test equipment required to perform the quality assurance/quality control function

- receiving procured equipment and verifying acceptance

- qualifying suppliers for fabrication of radioactive shipping containers

- preparing inspection/test procedures to be imposed on contractors

- preparing inspection plans for shipment of radioactive materials, containers, trucks, etc.

- finalizing the formal quality assurance plan.

The QA efforts during the actual dismantlement period include the following:

- performing QA functions for procurements

- qualifying suppliers

- auditing all project activities

- monitoring worker performance for compliance with work procedures

- verifying compliance of radioactive shipments with appropriate procedures and regulations

- performing dimensional, visual, nondestructive examinations or other required inspection services to assure compliance with work plans

- maintaining auditable files on the QA audits

- preparing a final report on overall performance of the dismantlement program with regard to the $Q A$ function.

More details of the anticipated elements of an appropriate quality assurance program for the dismantlement effort are given in Section G.5 of Appendix G. 


\subsubsection{Environmenta.l Surveillance}

An abbreviated version of the environmental monitoring program carried on during plant operation is continued during the dismantlement period. The purpose of the program is to identify and quantify any releases of radioactivity to the surrounding areas resulting from the dismantlement activities. The proposed program, detailed in Section G. 6 of Appendix G, is sufficient to permit evaluation of any significant releases. For emergency situations involving releases from events such as fires or malicious acts that may necessitate prompt emergency action to minimize the risk to the public, additional short term surveillance efforts are required.

After dismantlement is complete, a reduced 1-year follow-up program of environmental monitoring is carried out by the same organization that performed the earlier program.

\subsubsection{Specialty Contractors}

During decommissioning, specialty contractors are employed to provide services beyond the capability of the utility's decommissioning staff. Use of these contractors increases the overall cost-effectiveness of the project by improving the efficiency of specialty operations and reducing the need for specialized staff training. In addition, specialized experience gained from similar projects is directly applied to the decommissioning by these contractors, thus reducing the mistakes and wasted effort inherent in learn-as-you-go situations.

The specialty contractors used during immediate dismantlement of the reference BWR are:

- environmental monitoring specialists, for implementing the environmental surveillance program discussed previously

- explosive specialists, for breaking up the sacrificial shield

- hauling contractors, for transport of packaged radioactive materials to a disposal site 
- temporary radwaste handling and solidification support, for radwaste handling and final cleanup after the installed radwaste handling systems are decontaminated.

If following dismantlement the facility is demolished and the site is restored, demolition and landscaping contractors are also required.

\subsubsection{Essential Systems and Services}

All or parts of certain facility systems and services must remain in place and in service until all radioactive material is either removed from the facility or secured on the site, to prevent the release of significant quantities of radionuclides (or other hazardous materials) to the environment. Some systems and services are required for cleanup and disassembly activities. 0ther systems provide personnel health and safety protection. The required systems and services are listed in Table 9.1-1, together with the justification for retaining each.

As dismantlement is completed in areas within the facility, the essential systems and services in these areas are deactivated and, if contaminated, removed as required. Continuous service to the remaining work areas is maintained as long as necessary.

\subsubsection{Immediate Dismantlement Schedule}

The schedule and sequence of immediate dismantlement tasks is shown in Figure 9.1-1. Detailed schedules and manpower estimates for the immediate dismantlement of each of the three buildings are presented in Section I.2 of Appendix I in Volume 2. Initial planning for dismantlement of the reference BWR begins about 2 years before final shutdown of the reactor, as discussed previously in Section 9.1.1 and shown in Figure 9.1-1.

After final shutdown, the reactor is defueled. The spent fuel is shipped to an offsite respository after an initial 120-day cooling period. Initially, efforts are directed at draining contaminated systems. Dismantlement begins with removal of the reactor vessel internals, removal of the Reactor Building piping, and removal of the turbine. Dismantlement of equipment in the Radwaste and Control Building is delayed until nearly all of the contaminated water 
TABLE 9.1-1. Systems and Services Required During Immediate Dismantlement

\section{System or Service}

\section{Electrical Power}

HVAC Systems

Condensate Supply System

Plant Makeup Water Treatment System

Fire Protection System

Compressed Air Systems

(control and service)

Communications Systems

Radiation Monitoring Systems

Radwaste Systems

Fuel Pool Cooling and Cleanup System

\section{Reactor Building Closed}

Cooling Water System

Plant Service Water System

Auxiliary Boiler

Chemical Feed System

Fuel 0i1 System

Security Systems
Justification

Operation of electrical equipment including HVAC, lighting, and radiation monitoring

Ventilation and radioactive contamination confinement

water supply to spent fuel pool and radwaste systems

Decontamination, cleanup, fire protection, and potable water

Health and safety

Operation of pneumatic controls and tools;

personnel fresh air supply

Facilitate and coordinate decommissioning activities

Personnel safety considerations

Treatment of radioactive liquids and solids

Cleanup and cooling of water in spent fuel storage pool while spent fuel is there; in reactor well and dryer and separator pool during defueling and reactor vessel/internals removal

Secondary cooling of other systems

Air compressor cooling

HVAC heating and radwaste concentration

Radwaste handling and water demineralization

Auxiliary boiler operation

Public safety and plant protection considerations 
1 


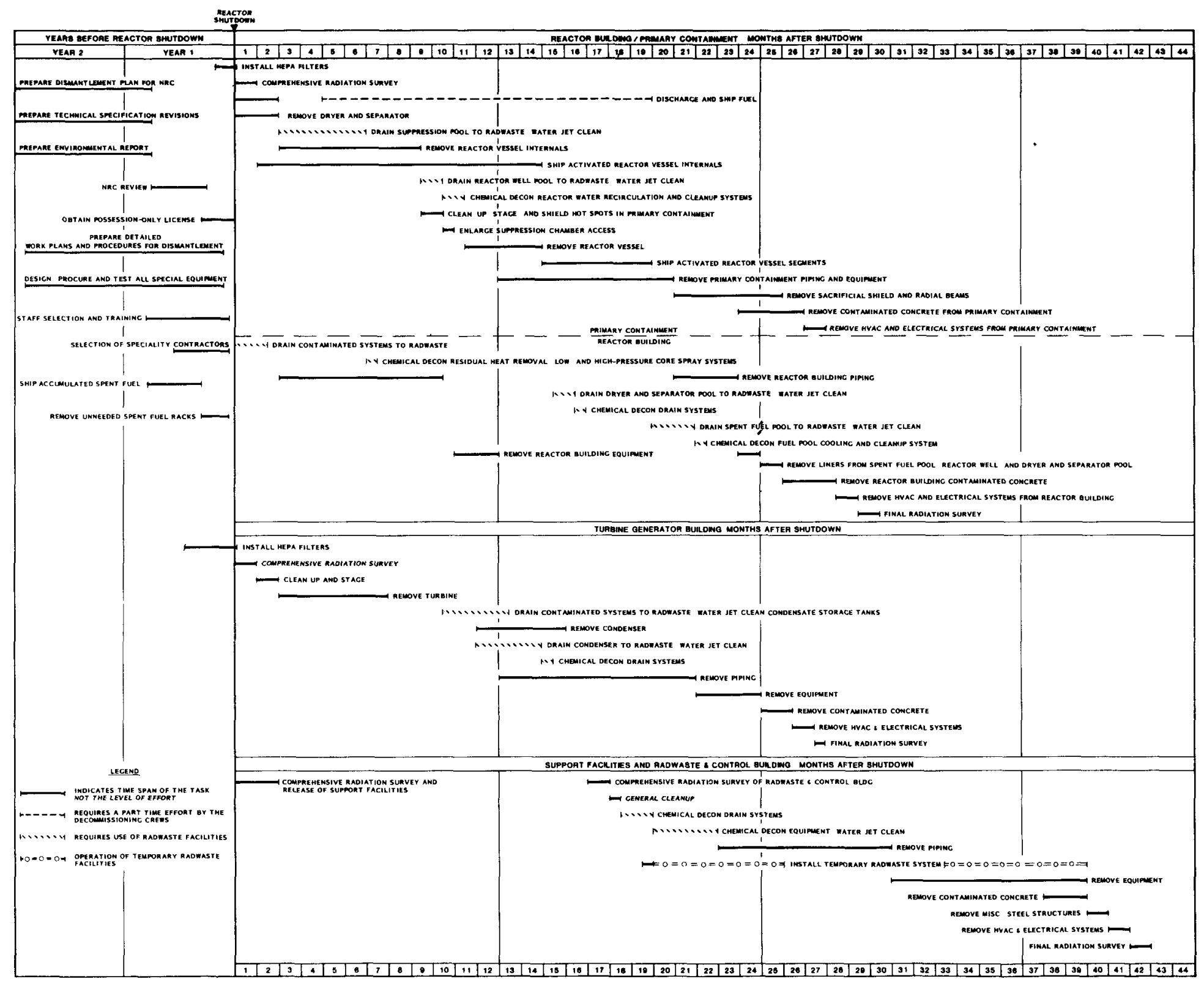

FIGURE 9.1-1. Overall Task Schedule and Sequence for Immethe Reference BWR

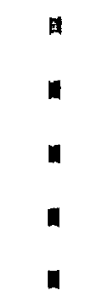

a

i


from the other buildings has been processed. As shown in Figure 9.1-1, immediate dismantlement of the reference BWR is completed in 42 months.

\subsubsection{Immediate Dismantlement Staff Requirements}

In this subsection, the organization of the decommissioning staff and the types and numbers of decommissioning workers needed for immediate dismantlement are discussed.

\subsubsection{Organization of the Decommissioning Staff}

The decommissioning staff for the reference BWR is organized as shown in Figure 9.1-2. Two main and three auxiliary parallel branches report to a decommissioning superintendent. The operational branch, under a decommissioning engineer, plans and performs the actual decommissioning tasks. The safety branch, under a health and safety supervisor, plans and conducts both radiological and industrial safety programs. The auxiliary branches handle security, financial, and quality assurance matters.

The primary decommissioning activities are performed on a two-shift, 5-day-per-week basis. However, support activities (i.e., system decontamination and draining, spent-fuel/activated material shipping, radwaste system operation and security functions) are carried out on a three-shift, around-the-clock, 7-day-per-week basis. In addition, the main control room is manned full time for operation of the essential systems and services.

The basic working unit is the shift, which is supervised by a shift engineer. The crew on each shift includes: a crew leader (typically a reactor operator), utility operators, and laborers, plus craftsmen (e.g., welders, pipefitters, electricians, and air-balance technicians) and health physics technicians assigned as needed. Craftsmen and health physics technicians on the support crews report directly to the crew leaders because, on the third shift and on weekends, these crew leaders are the only supervisory personinel on plant. Craftsmen and health physics technicians assigned to the regular decommissioning crews report to the crafts supervisor and the senior health physics technician on the shift, respectively. 


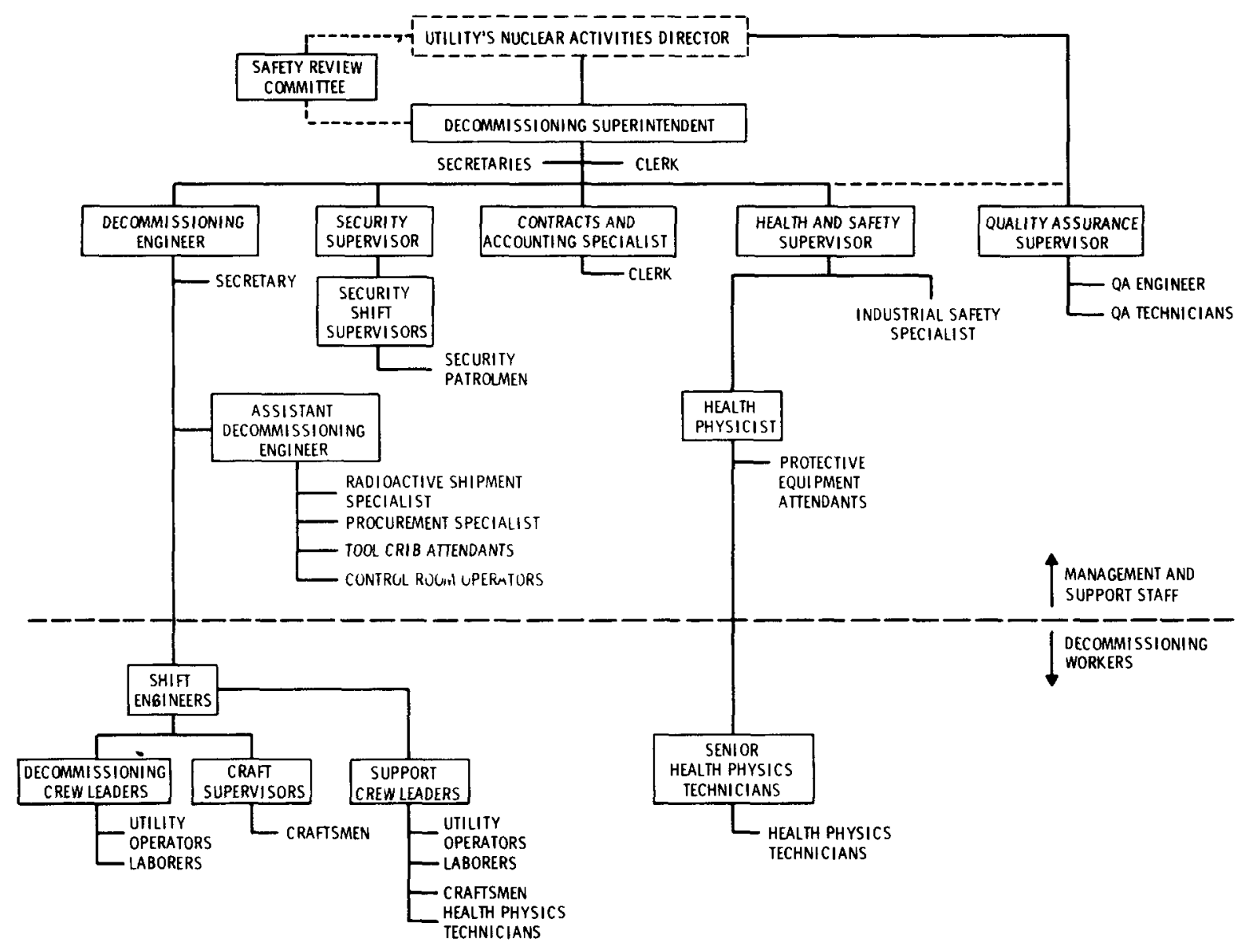

FIGURE 9.1-2. Decommissioning Staff Organization

Detailed knowledge of and familiarity with the reference BWR increases the effectiveness of the decommissioning staff. Consequently, staff positions are fill with facility operations and maintenance personnel to the maximum extent possiole. Specialty contractors and consultants are hired as needed to assist in areas outside the staff's expertise or capability.

This discussion is limited to the decommissioning staff, and does not include utility staff members involved in predecommissioning activities prior to final plant shutdown.

Key decommissioning staff members perform the functions described in the following subsections. 
Decommissioning Superintendent. Directly responsible to corporate management, the superintendent coordinates and oversees all decommissioning activities. He directs the decommissioning engineer and the health and safety supervisor, as well as security, quality assurance, and contracts and accounting, to ensure the safety and cost-effectiveness of the decommissioning project. He provides necessary liaison with regulatory agencies and utility management.

Decommissioning Engineer. This person supervises the decommissioning support personnel and assists the decommissioning superintendent in developing detailed work procedures. He writes specifications for special equipment and tools that must be procured or fabricated. He also prepares reports requested by the decommissioning engineer.

Shift Engineer. Responsible for carrying out the actual decommissioning work during a shift, this person supervises the crew leader and craft supervisor. He reports to the decommissioning engineer. As he supervises the day-to-day performance of the shift, he recommends changes in procedures and schedules to improve the safety and/or cost effectiveness of the project.

Crew Leader. Reporting to the shift engineer, this individual directs the work crews in the performance of the actual decommissioning tasks.

Craft Supervisor. This person is responsible for maintenance of essential plant equipment and services, as well as for assigning craft labor to particular decommissioning tasks. He instructs craftsmen in their assigned tasks and ensures the availability of required tools and supplies.

Security Supervisor. This person is responsible for site security during decommissioning. He supervises the security personnel and, if necessary, provides liaison with offsite civil authorities. The security shift supervisor directs shift activities.

Contracts and Accounting Specialist. As an experienced accountant, this individual is responsible for the financial aspects of the project. He prepares procurement documents and contracts and, with approval from the decommissioning superintendent and the decommissioning engineer, disburses funds. He maintains up-to-date financial accounts and provides the decommissioning superintendent with regular summary reborts. 
Health and Safety Supervisor. This person (typically a senior health physicist) recommends and enforces safety policy, both radiological and industrial. He advises the decommissioning superintendent on all safety matters. He maintains the occupational radiation exposure records, and also develops and implements the environmental survey (via a specialty contractor) and the emergency preparedness programs. He supervises and is assisted by the industrial safety specialist and the health physicist.

Health Physicist. Responsible for ensuring compliance with radiation work procedures, this individual directs the activities of the health physics technicians, who monitor all decommissioning activities, measure and record on-the-job radiation dose information, and operate the plant laboratory facilities, including sampling and analysis.

The senior health physics technician assigns and trains the others on the shift.

Quality Assurance Supervisor. This person is responsible for preparing the quality assurance plan for decommissioning and works with the decommissioning engineer to implement it. To ensure the independence of the quality assurance program, he reports directly to corporate headquarters. He supervises a quality assurance unit, which maintains audit- and job-performance records and verifies that established safety review procedures are followed. (See Section G.5 of Appendix $G$ for further discussion of quality assurance functions.)

Safety Review Committee. This committee advises corporate management (the utility's nuclear activities director) and the decommissioning superintendent on safety-related matters. It has six voting members: two from corporate headquarters and four independent consultants. The decommissioning superintendent, the quality assurance supervisor, the decommissioning engineer, and the health and safety supervisor are nonvoting members. Resolution of all issues requires agreement by a majority of the consultants. The committee meets about once a month during active decommissioning. The decommissioning superintendent implements the committee's decisions. 


\subsubsection{Immediate Dismantlement Manpower}

Based on the schedule for dismantling the various systems and the estimated dose to accomplish each task, the types and number of decommissioning workers needed to complete the radiation-zone work in the allotted time and within the assumed radiation dose limits are determined. Whole-body radiation doses to the decommissioning workers are limited in accordance with 10 CFR 20.101. The supervisors, utility operators, and health physics technicians are assumed to be long-time radiation workers whose annual exposure is limited to 5 rem per year by the formula $5(\mathrm{~N}-18)$ of 10 CFR 20.101 (b)(2). The craftsmen and laborers are assumed to have had little prior radiation exposure and, therefore, under 10 CFR 20.101(b)(1) and (2) may receive up to 3 rem per quarter, within the limitation of the formula $5(\mathrm{~N}-18)$. In those instances where manpower estimates for physically accomplishing a task result in an average dose for each person in excess of the limits above, additional manpower is assigned to the tasks to keep the occupational dose below the set limits. In the manpower tables following, the manpower shown is adequate both to accomplish the task and to meet the occupational dose limits.

In Table 9.7-2, the estimated number of decommissioning workers of each type is shown for each month of the immediate dismantlement effort. A total of about 4000 man-months of "hands-on" effort is required.

Staff labor requirements for immediate dismantlement of the reference BWR are given in Table 9.1-3. The requirements are given in equivalent man-years for the 2 years before and the 4 years following final reactor shutdown and include the management and support staff, as well as the decommissioning workers. A tota 1 effort of just over 600 man-years is estimated for completion of immediate dismantlement.

\subsection{PASSIVE SAFE STORAGE ACTIVITIES AND MANPOWER REQUIREMENTS}

The passive safe storage approach to decommissioning satisfies the requirements for protection of the public, while minimizing, in various degrees, the initial commitments of time, money, occupational radiation dose, and nuclear waste repository space. This advantage is offset somewhat by the need to maintain the nuclear license, by the associated restrictions placed on the use of 
1 
TABLE 9.1-2. Overal1 Decommissioning Worker Requirements for Immediate Dismantlement of the Reference BWR

\begin{tabular}{|c|c|c|c|c|c|c|c|c|c|c|c|c|c|c|c|c|c|c|c|c|c|c|c|c|c|c|c|c|c|c|c|c|c|c|c|c|c|c|c|c|c|}
\hline \multicolumn{2}{|l|}{ SUMMAAY/MANPOWEA } & \multicolumn{40}{|c|}{ SUMMAAY MAN-MONTHS PER WORKING MONTH } \\
\hline LABOR GAADE & TOTAL M/M & $1 \mid 2$ & 3 & 4 & 5 & 8 & 7 & 8 & $\cdot$ & 10 & 11 & 12 & 13 & 14 & 15] & 16 | & 17 | & 18 1 1 & 102 & 2021 & \begin{tabular}{l|l|l|l|l|l|l}
21 & 22 \\
\end{tabular} & 23 & 24 & 25. & 26 & 27 & 28 & 20 & 30 & 31 & 32 & 33 & 34 & 35 & 36 & 37 & 38 & 39 & 40 & 41 & 42 \\
\hline SHIFT ENCINEER & 84.0 & 2 & 2 & 2 & 2 & 2 & 2 & 2 & 2 & 2 & 2 & 2 & 2 & 2 & 2 & 2 & 2 & 2 & 2 & 2 & 2 & 2 & 2 & 2 & 2 & 2 & 2 & 2 & 2 & 2 & 2 & 2 & 2 & 2 & 2 & 2 & 2 & 2 & 2 & 2 & 2 \\
\hline CREW LEADER & 338.1 & $\begin{array}{lll}6.2 & 12.7\end{array}$ & 714.81 & 14.8 & 14.8 & 14.8 & 14.91 & 10.61 & 12.71 & 19.11 & 19.1 & 14.8 & 14.8 & 14.8 & 17 & 1710 & 0.61 & 12.714 & & 0.410. & 0.48 .3 & 32 & 2 & 2 & 2 & 2 & 2 & 2 & 2 & 2 & 2 & 2 & 2 & 2 & 2 & 2 & 2 & 2 & 2 & 2 & - \\
\hline UTLLIY OPERATOR & 1265.4 & 35.141 .4 & 453.95 & 53.9 & 53.9 & 53.96 & 49.63 & 34.84 & 40.45 & 51.85 & 52.7 & 47.9 & 51.95 & 51.95 & 54.2 & 50.228 & 28.83 & 88.445 & 5.950 & 50.252. & 2.243 .4 & 432 & 24 & 14 & 14 & 13 & 12 & 12 & 10 & 10 & 10 & 10 & 10 & 10 & 10 & 10 & 12 & 12 & 2 & 2 & - \\
\hline LABORER & 651.0 & -4 & 16 & 16 & 16 & 16 & 16 & 12 & 15 & 11 & 10 & 22 & 24 & 24 & 24 & 121 & 12 & $14 \quad 1$ & 131 & $12 \quad 20$ & $20 \quad 22$ & 24 & 36 & 38 & 30 & 22 & 15 & 11 & 8 & 12 & 12 & 12 & 12 & 12 & 12 & 12 & 20 & 20 & 4 & 8 & - \\
\hline CRAFT SUFERVISOR & 82.0 & 2 & 2 & 2 & 2 & 2 & 2 & 2 & 2 & 2 & 2 & 2 & 2 & 2 & 2 & 2 & 2 & 2 & 2 & 2 & 2 & 2 & 2 & 2 & 2 & 2 & 2 & 2 & 2 & 2 & 2 & 2 & 2 & 2 & 2 & 2 & 2 & 2 & 2 & 2 & - \\
\hline CRAFTSISAN & 998.0 & 18 & 28 & 28 & 28 & 28 & 28 & 20 & 18 & 13 & 14 & 34 & 44 & 44 & 40 & 28 & 28 & 33 & 29 & 28 & 36 & 52 & 48 & 46 & 31 & 32 & 27 & 23 & 16 & 10 & 10 & 10 & 10 & 10 & 10 & 10 & 10 & 10 & 10 & 8 & - \\
\hline SEMYOR H & 94. & 4 & 2 & 2 & 2 & 2 & 2 & 2 & 2 & 2 & 2 & 2 & 2 & 2 & 2 & 2 & 4 & 2 & 2 & 2 & 2 & 2 & 2 & 2 & 2 & 3 & 2 & 2 & 3 & 2 & 2 & 2 & 2 & 2 & 2 & 2 & 2 & 2 & 2 & 2 & 2 \\
\hline HEALTH PHYSICS TECHNICIAN & 532.4 & 18.214 .3 & 312.41 & 12.41 & & 12.4 & 12.5 & 6.2 & $8.3 \mathrm{H}$ & 15.31 & 16.7 & & 12.4 & & & 14.610 & 10.21 & & & 2.412 & 2.410 .3 & 322 & 22 & 20 & 15 & 15 & 13 & 13 & 12 & 13 & 13 & 13 & 13 & 13 & 13 & 13 & 13 & 13 & 2 & 2 & 2 \\
\hline
\end{tabular}

TABLE 9.1-2. Overal1 Decommissioning Worker Requirements for

Immediate Dismantlement
of the Reference BWR

$9-23$
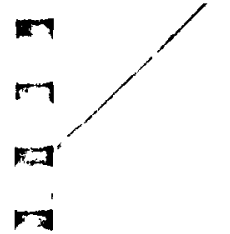

t. 1

4. 1

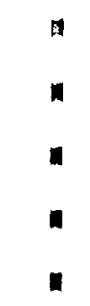
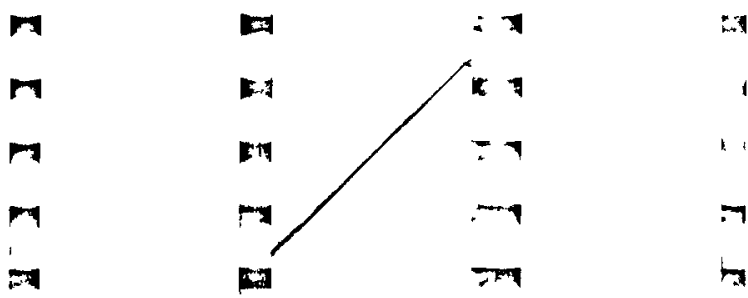

n

a

c.

t)

$\rightarrow$

1 
TABLE 9.1-3. Staff Labor Requirements for Immediate Dismantlement

Position

Time Relative to Final Reactor Shutdown (year)
$\frac{-2}{\text { Annual Staff Labor Requirement } \frac{-1}{3}} \frac{4}{4} \frac{4}{\text { (man-years)(a) }}$

Total Staff

Labor Required

(man-years)

Management and Support Staff

Decomissioning Superintendent Secretary

clerk

Decomissioning Engineer

Assistant Decommissioning Engineer

Radioactive Shipment Specialist.

Procurement Specialist

Tool Crib Attendant

Control Room Operator (c)

Security Supervisor
Security Shift Superyisor(d)

Security Patrolman(d)

Contracts and Accounting Specialist

Health and Safety Supervisor

Heal th Physicist

Protective Equipment Attendant

Industrial Safety Specialist

Quality Assurance Supervisor

Quality Assurance Engineer

Quality Assurance Technician

Consul tant (Safety Review)

Subtotals, Management and Support Staff

Decommissioning Workers (e)

Shift Engineer

Crew Leader(f)

Utility Operator $(g)$

Laborer

Craft Supervisor

Craftsman

Senior Health Physics Technician Health Physics Technician $(h)$

Subtotals, Decommissioning Workers

Totals

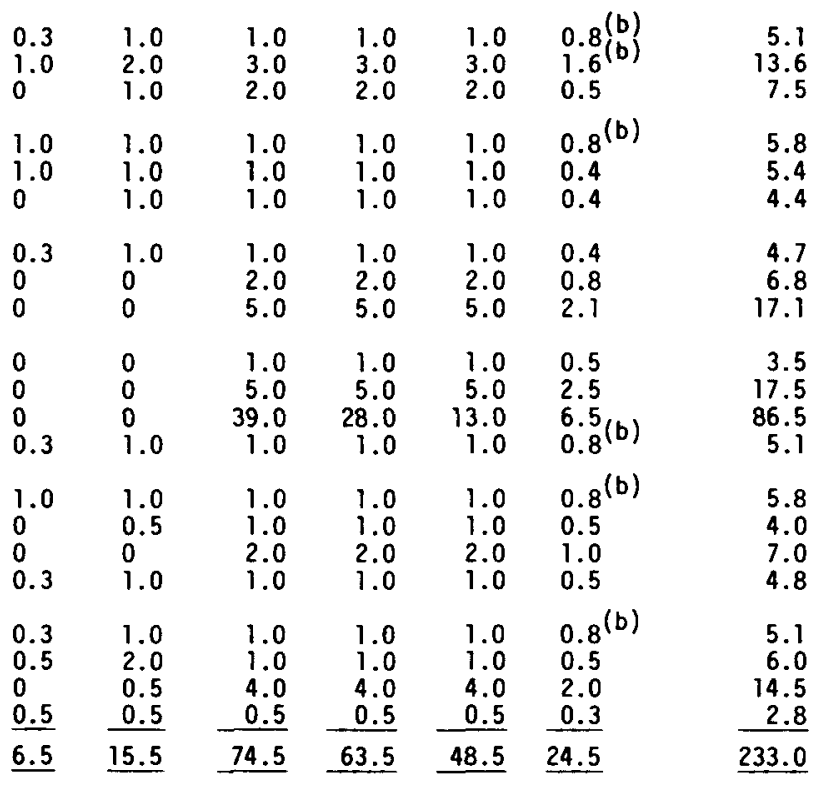

\begin{tabular}{|c|c|c|c|c|c|c|}
\hline $\begin{array}{l}1.0 \\
0\end{array}$ & $\begin{array}{l}2.0 \\
1.0\end{array}$ & $\begin{array}{r}2.0 \\
15.7\end{array}$ & $\begin{array}{r}2.0 \\
12.0\end{array}$ & $\begin{array}{l}2.0 \\
2.0\end{array}$ & $\begin{array}{l}1.0 \\
0.8\end{array}$ & $\begin{array}{l}10.0 \\
31.5\end{array}$ \\
\hline $\begin{array}{l}0 \\
0 \\
0\end{array}$ & $\begin{array}{l}3.2 \\
0 \\
0.6\end{array}$ & $\begin{array}{r}55.0 \\
12.9 \\
2.0\end{array}$ & $\begin{array}{r}49.6 \\
19.8 \\
2.0\end{array}$ & $\begin{array}{r}12.4 \\
16.3 \\
2.0\end{array}$ & $\begin{array}{l}3.3 \\
5.3 \\
0.8\end{array}$ & $\begin{array}{r}123.5 \\
54.3 \\
7.4\end{array}$ \\
\hline $\begin{array}{l}0 \\
0\end{array}$ & $\begin{array}{r}10.0 \\
1.0 \\
3.0 \\
\end{array}$ & $\begin{array}{r}22.4 \\
2.5 \\
14.3 \\
\end{array}$ & $\begin{array}{r}37.2 \\
2.2 \\
14.9 \\
\end{array}$ & $\begin{array}{r}19.6 \\
2.1 \\
14.0 \\
\end{array}$ & $\begin{array}{l}4.0 \\
1.0 \\
3.8 \\
\end{array}$ & $\begin{array}{r}93.2 \\
8.8 \\
50.0 \\
\end{array}$ \\
\hline 1.0 & 20.8 & 126.8 & 139.7 & 70.4 & $\underline{20.0}$ & 378.7 \\
\hline 7.5 & 36.3 & 201.3 & 203.2 & 118.9 & 44.5 & 611.7 \\
\hline
\end{tabular}

(a) Rounded to the next higher 0.1 man-year.

(b) Includes an additional 4 months following active decommissioning in order to complete the documentation and other unspecified license and contract termination requirements.

(c)Based on one operator per shift in the control room, three shifts per day, 7 days per week.

(d) Based on 10 CFR Part 73 and information obtained from Washington Public Power Supply System; includes both response and access-control personnel on a three-shift, 7-day-week basi's.

(e) Requirements during the 4 years following reactor shutdown are based on Table I.2-2, unless otherwise noted; individual man-month requirements in Table $\mathrm{I} .2-2$ are rounded to the next higher 1.0 man-month in calculating these requirements.

(f)Based on a constant loading of 15 people through month 19 following reactor shutdown, with additional personnel added as required to meet schedule demands during that period, and diminishing thereafter as the schedule allows.

(g)Based on a constant loading of 55 people through month 21 following reactor shutdown, diminishing as the schedule allows, except during months 30 through 37 when 12 trained personnel are maintained to meet the requirements during months 38 and 39.

(h)Based on a constant loading of 13 people through month 39 following reactor shutdown, with additional personnel added as required to meet schedule demands during that period. 
the property, and by the need for eventual dismantlement of the facility. After an initial preparatory period following plant shutdown, this mode requires continuing physical security and surveillance (continuing care) of structural integrity to ensure public protection. Planning and preparation activities, passive safe storage preparations activities, schedule and manpower estimates, and continuing care activities and requirements for the reference BWR are discussed in the following subsections.

Deferred dismantlement at the end of the continuing care period is discussed in Section 9.4 .

\subsubsection{Planning and Preparation Activities}

Successful implementation of passive safe storage for the reference BWR is dependent both on good planning and on completion of preparatory work before final reactor shutdown. Planning and preparation for passive safe storage is assumed accomplished during the 18 months prior to final reactor shutdown.

The planning and preparation activities for passive safe storage, with one exception, are essentially the same as those described in Section 9.1.1 for immediate dismantlement and are not discussed further here. The one exception is that all of the spent fuel storage racks are left intact and in-place for the duration of the continuing care period.

\subsubsection{Passive Safe Storage Preparations Activities}

The activities and requirements to prepare the reference BWR for passive safe storage include:

- decontamination and immobilizing contamination

- systems deactivation and isolation of contaminated areas

- reduction of plant exclusion area

- quality assurance

- environmental surveillance

- specialty contractors

- essential systems and services.

These are discussed in the following subsections. 


\subsubsection{Decontamination and Immobilizing Contamination}

At final reactor shutdown, significant radioactive contamination is present on the surfaces of process systems and equipment. Decontamination is relied upon to remove the bulk of this radioactive contamination from selected systems and components. The objectives of the decontamination effort are to reduce the radiation levels and to immobilize radioactive contamination throughout the facility in order to minimize personnel exposure during subsequent decommissioning tasks and later during continuing care activities.

Decontamination of Process Systems. Two process system decontamination methods are used: chemical decontamination and watér-jet cleaning. The decontamination activities required for passive safe storage are identical to those for immediate dismantlement, which are discussed in Section 9.1.2.1

Although all the decontamination activities specified for immediate dismantlement are assumed for passive safe storage preparations in their entirety, some of the water-jet cleaning tasks and some equipment decontamination tasks may or may not be performed, at the discretion of the facility owner. In addition, the total volume of radioactively contaminated water that is generated from miscellaneous sources over the active decommissioning period is reduced because the time period is less. A lesser volume of contaminated water means that less radioactive ion exchange resins are produced, thus decreasing the disposal costs.

Decontamination of Ventilation Systems. The exhaust ductwork from the Reactor Building (including Primary Containment), the Turbine Generator Building, and the Radwaste and Control Building is decontaminated as required. Decontamination procedures used during plant operations are generally followed. It is expected that the decontamination effort will consist primarily of hot water flushes to remove dirt and grease. Chemical solutions may be used if there is significant buildup of contamination. The first stage of the HEPA filters is replaced during these operations, where necessary. Subsequent stages of HEPA filters are replaced only if replacement is required due to damage or high-pressure drop. 
Decontamination and Isolation of the Reactor Refueling Pools. After the fuel is removed, the reactor vessel is secured using normal procedures. The reactor well pool cavity and the dryer and separator storage pool cavity are drained and decontaminated.

The reactor well pool is isolated by installing the existing concrete cover blocks; thus, no further decommissioning of that pool is required. The dryer and separator storage pool cavity is isolated by installing a welded, carbon steel cover over the cavity area. In addition, a HEPA-filtered vent pipe, integral to the welded cover, is provided to allow for changes in air pressure and temperature.

After the last fuel shipment has left the site, the spent fuel storage pool cavity is drained and decontaminated. The cavity is isolated in a manner similar to that described above for the dryer and separator storage pool cavity.

Mechanical Decontamination and Fixing of Residual Contamination. Mechanical decontamination of structures is carried out only in areas, such as hallways and corridors, that contribute significantly to the radiation doses to surveillance and maintenance personnel. Drilling and spalling or jackhammering are used. The contaminated materials that are removed are packaged and either shipped to a burial site or placed in one of the areas that is isolated prior to the continuing care period. Combustible materials are packaged and shipped offsite for disposal.

Some residual amounts of low-level contamination may be present in areas outside the isolated areas. These areas typically contain amounts of radioactivity that do not contribute significantly to occupational radiation dose rates in the facility. This contamination is immobilized by covering it with paint or other protective coatings to prevent the contamination from becoming airborne.

\subsubsection{Systems Deactivation and Isolation of Contaminated Areas}

Only essential safety systems such as radiation detection alarms, security monitors, and fire detection and portable fire fighting equipment remain in operation during passive safe storage. All other equipment and systems are 
placed in a condition that provides maximum safety with minimum maintenance. Whenever possible, equipment is left in a condition that permits later salvage.

Portions of the facility containing significant amounts of radioactivity are isolated from trepassing by tamper-proof barriers. Indirect access routes, however unlikely, are also sealed. Such routes may include, but are not $1 \mathrm{im-}$ ited to, access through large vessels, tanks, or large-diameter pipes that could allow such trespass, willful or otherwise.

A pressure-equalization line is provided between the outside environment and the interiors of the Reactor Building, the Turbine Generator Building, and the Radwaste and Control Building. The pipes used for this purpose are provided with replaceable absolute filters. The lines prevent pressure differentials caused by changes in temperature and atmospheric pressure from developing between the inside and the outside of sealed areas.

\subsubsection{Reduction of Plant Exclusion Area}

In addition to the above activities, the exclusion area surrounding the plant is reduced to a minimum size, as depicted in Figure 9.2-1. The structures and site surfaces outside of the new exclusion area but within the previous site perimeter fence are assumed to be surveyed and released for unrestricted use without further effort.

The final plant condition proceeding into continuing care is one with the transportable radioactivity either removed or immobilized, but with significant quantities (millions of curies) of fixed radioactivity remaining in the primary containment vessel (see Figure 7.2-6 in Chapter 7).

\subsubsection{Quality Assurance}

An extensive quality assurance program is carried on throughout the decommissioning effort to assure that all applicable regulations are met, to assure that the work is performed according to plan, to assure that the work does not endanger public safety, and to assure the safety of the decommissioning staff. The quality assurance program for passive safe storage is essentially the same as that for immediate dismantlement, which is described in Section 9.1.2.3. 


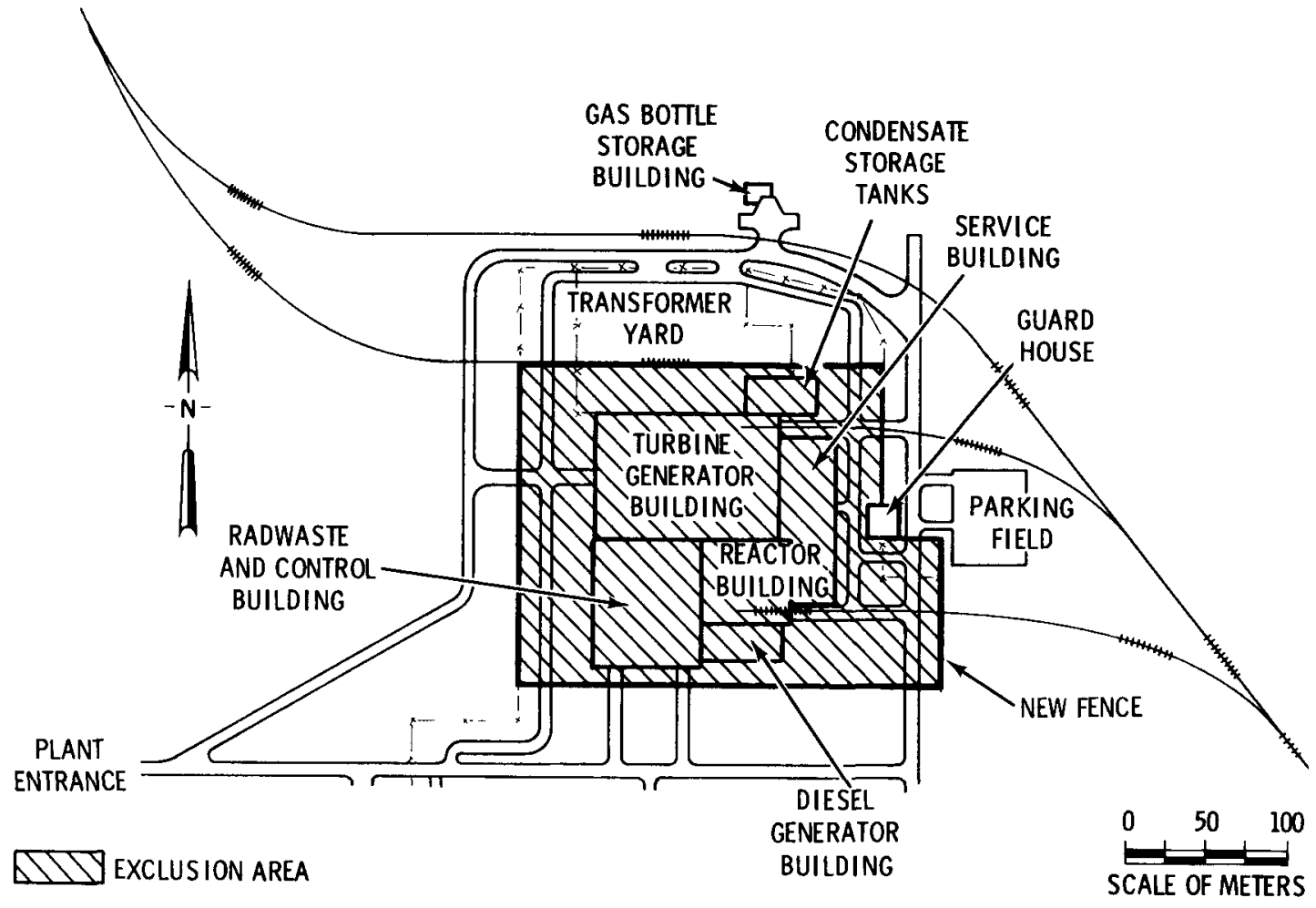

FIGURE 9.2-1. Plot Plan of the Exclusion Area for Passive Safe Storage

\subsubsection{Environmental Surveillance}

The required levels of environmental surveillance during the preparations for passive safe storage differ from those during continuing care. An abbreviated version of the environmental monitoring program carried on during plant operation is continued during the preparations for passive safe storage. This program is the same as that for immediate dismantlement (see Section 9.1.2.4).

\subsubsection{Specialty Contractors}

As with immediate dismantlement, specialty contractors are required both for preparations for passive safe storage and for continuing care.

The specialty contractors required during preparations for passive safe storage of the reference BWR are: 
- environmental monitoring specialists, for implementing the environmental surveillance program discussed previously.

- hauling contractors, for transport of packaged radioactive materials to a disposal site

- temporary radwaste handling and solidification support, for radwaste handling and final cleanup after the installed radwaste handling systems are decontaminated.

- commercial security agency, for installing, operating, and maintaining electronic surveillance systems.

\subsubsection{Essential Systems and Services}

The required systems and services for preparations for passive safe storage differ from those required for continuing care. Specific systems and services must remain in service until radioactive and/or contaminated materials are decontaminated, fixed in place, or removed from the facility, to prevent the release of significant quantities of radionuclides or other hazardous materials to the environment. The systems and services required for preparations for passive safe storage are the same as those required for immediate dismantlement, which are discussed in Section 9.1.2.6.

\subsubsection{Passive Safe Storage Schedule}

The schedule and sequence of passive safe storage decommissioning tasks is shown in Figure 9.2-2. Further schedule details are presented in Section J.4 of Appendix J. Initial planning for passive safe storage of the reference BWR begins about 18 months before final shutdown.

After final shutdown, the reactor is defueled. The spent fuel is shipped to an offsite location after an initial 120-day cooling period. Initial efforts are directed at draining contaminated systems. Decommissioning activities in the Radwaste and Control Building are delayed until nearly all of the contaminated water from the other buildings has been processed. As shown in Figure 9.2-2, preparations for passive safe storage are completed in about 30 months. 


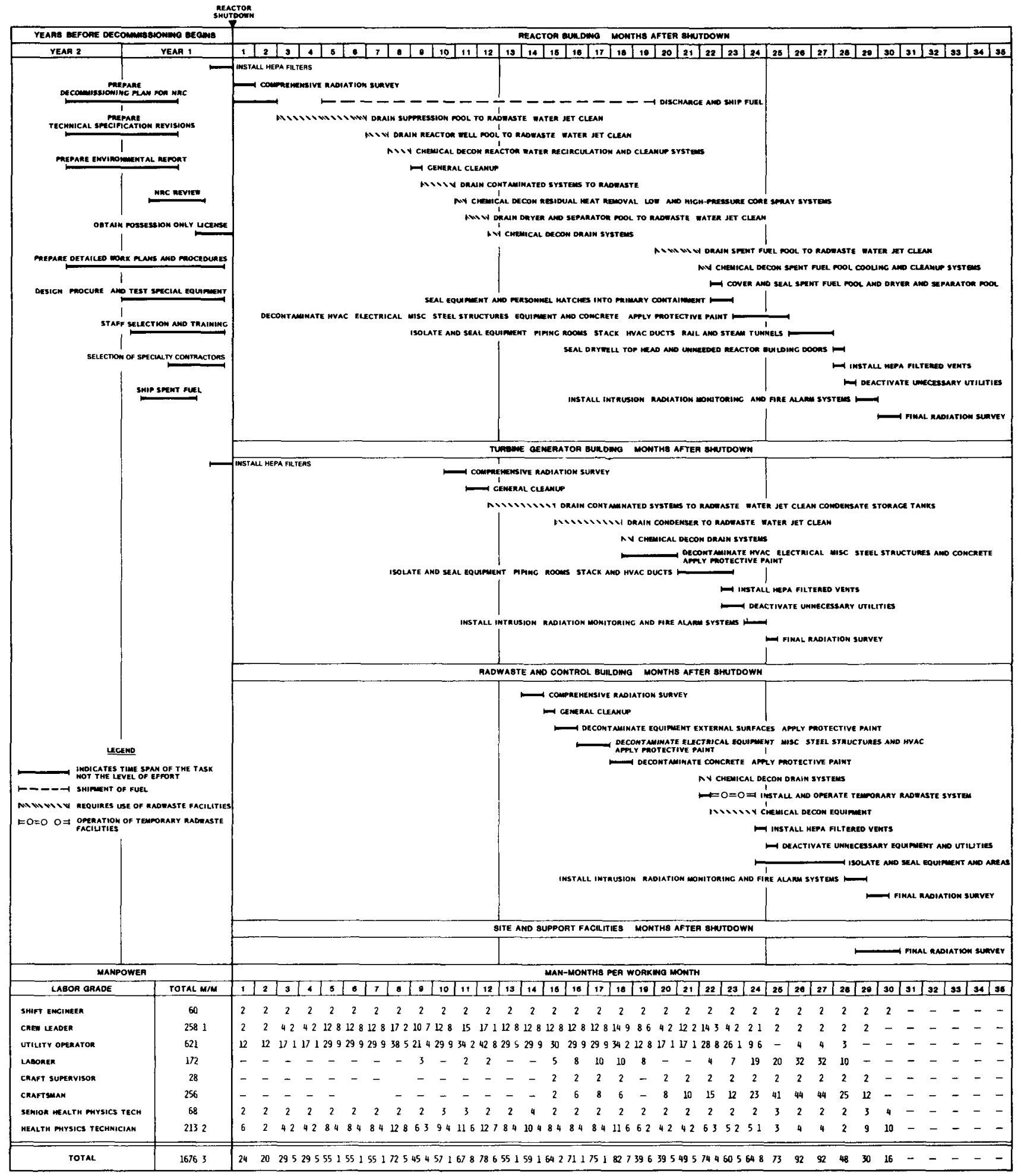

FIGURE 9.2-2. Task Schedule and Sequence of Preparations for Passive Safe Storage 


\subsubsection{Pasive Safe Storage Preparations Staff Requirements}

The organization and functions of the passive safe storage decommissioning staff are the same as those for immediate dismantlement, as discussed in Section 9.1.4.1.

Estimates of manpower requirements are based on the preparations for passive safe storage schedule and take into account both radiation dose limits and manpower limits needed to complete the individual tasks. The estimated number of decommissioning workers in each category is shown for each month of preparations for passive safe storage at the bottom of Figure 9.2-2. A total of about 1700 man-months of "hands-on" effort is required. This total, however, does not include extra manpower that is maintained during certain periods to meet fluctuating peak demands.

The total staff labor requirements for preparations for passive safe storage of the reference BWR are given in Table 9.2-1. The requirements are given in equivalent man-years for the 2 years before and the 3 years following final reactor shutdown, and include the management and support staff as well as the decommissioning workers. A total effort of approximately 385 man-years is estimated for completion of preparations for passive safe storage.

\subsubsection{Continuing Care Activities and Requirements}

Activities at the reference BWR site during the continuing care period that follows placing the facility in passive safe storage include routine inspection, preventive and corrective maintenance on safety systems, and a regular program of radiation and environmental monitoring. Action is initiated immediately to correct any unusual or potentially unsafe condition detected during the surveillance program. In addition to the routine tasks, a comprehensive inspection of the facility is performed annually by qualified thirdparty inspectors. Because of the massive construction of the main building structures, deterioration of the buildings sufficient to require major repairs is considered unlikely.

The continuing care period lasts until final disposition of the facility is made. The length of this period is determined by a cost-benefit analysis 


\section{TABLE 9.2-1. Staff Labor Requirements for Preparations for Passive Safe Storage}

Position

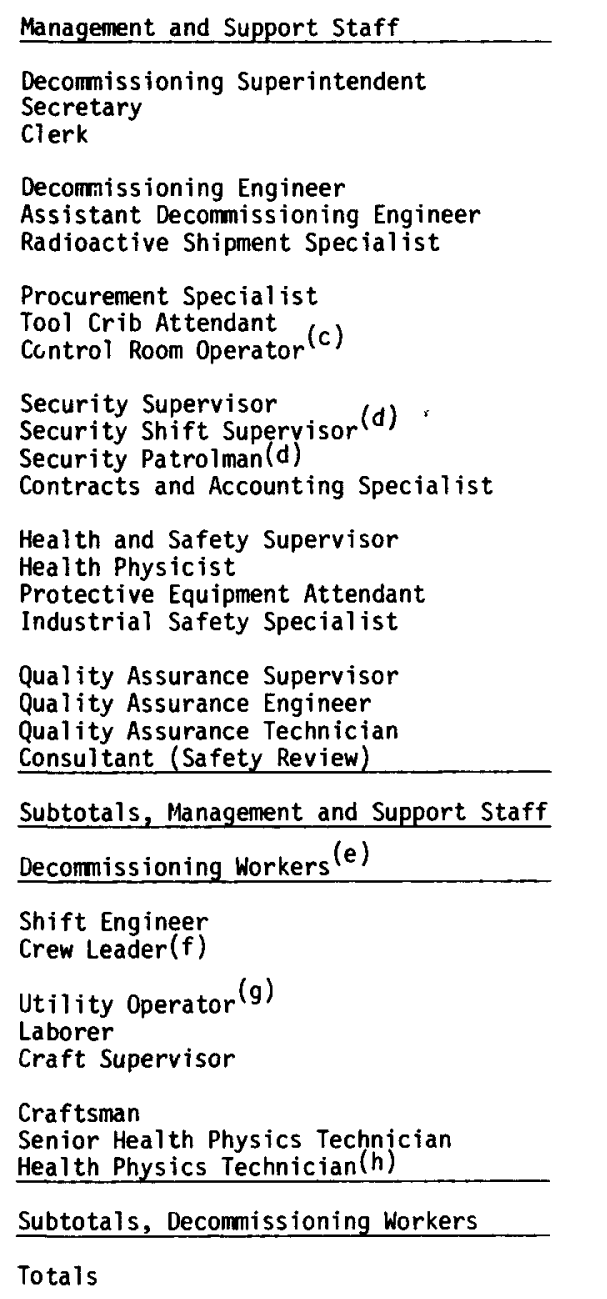

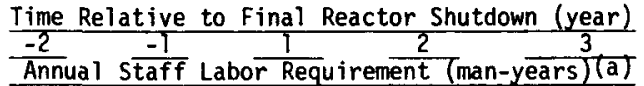

Total Staff Labor Required (man-years)

\begin{tabular}{|c|c|c|c|c|c|}
\hline $\begin{array}{l}0.5 \\
0.5 \\
0\end{array}$ & $\begin{array}{l}1.0 \\
2.0 \\
1.0\end{array}$ & $\begin{array}{l}1.0 \\
3.0 \\
2.0\end{array}$ & $\begin{array}{l}1.0 \\
3.0 \\
2.0\end{array}$ & $\begin{array}{l}0.8(b) \\
1.6^{(b)} \\
0.5\end{array}$ & $\begin{array}{r}4.3 \\
10.1 \\
5.5\end{array}$ \\
\hline $\begin{array}{l}0.5 \\
0.5 \\
0\end{array}$ & $\begin{array}{l}1.0 \\
1.0 \\
1.0\end{array}$ & $\begin{array}{l}1.0 \\
1.0 \\
1.0\end{array}$ & $\begin{array}{l}1.0 \\
1.0 \\
1.0\end{array}$ & $\begin{array}{l}0.8^{\text {(b) }} \\
0.4^{\text {b }} \\
0.4\end{array}$ & $\begin{array}{l}4.3 \\
3.9 \\
3.4\end{array}$ \\
\hline $\begin{array}{l}0.2 \\
0 \\
0\end{array}$ & $\begin{array}{l}1.0 \\
0 \\
0\end{array}$ & $\begin{array}{l}1.0 \\
2.0 \\
5.0\end{array}$ & $\begin{array}{l}1.0 \\
2.0 \\
5.0\end{array}$ & $\begin{array}{l}0.4 \\
0.8 \\
2.1\end{array}$ & $\begin{array}{r}3.6 \\
4.8 \\
12.1\end{array}$ \\
\hline $\begin{array}{l}0 \\
0 \\
0 \\
0.2\end{array}$ & $\begin{array}{l}0 \\
0 \\
0 \\
1.0\end{array}$ & $\begin{array}{r}1.0 \\
5.0 \\
39.0 \\
1.0\end{array}$ & $\begin{array}{r}1.0 \\
5.0 \\
28.0 \\
1.0\end{array}$ & $\begin{array}{l}0.5 \\
2.5 \\
6.5 \\
0.8(b)\end{array}$ & $\begin{array}{r}2.5 \\
12.5 \\
73.5 \\
4.0\end{array}$ \\
\hline $\begin{array}{l}0.5 \\
0 \\
0 \\
0.2\end{array}$ & $\begin{array}{l}1.0 \\
0.5 \\
0 \\
1.0\end{array}$ & $\begin{array}{l}1.0 \\
1.0 \\
2.0 \\
1.0\end{array}$ & $\begin{array}{l}1.0 \\
1.0 \\
2.0 \\
1.0\end{array}$ & $\begin{array}{l}0.8^{(b)} \\
0.5 \\
1.0 \\
0.5\end{array}$ & $\begin{array}{l}4.3 \\
3.0 \\
5.0 \\
3.7\end{array}$ \\
\hline $\begin{array}{l}0.2 \\
0.3 \\
0 \\
0.3 \\
\end{array}$ & $\begin{array}{l}1.0 \\
2.0 \\
0.5 \\
0.5 \\
\end{array}$ & $\begin{array}{l}1.0 \\
1.0 \\
2.0 \\
0.5 \\
\end{array}$ & $\begin{array}{l}1.0 \\
1.0 \\
2.0 \\
0.5 \\
\end{array}$ & $\begin{array}{l}0.8^{(b)} \\
0.5 \\
1.0 \\
0.3 \\
\end{array}$ & $\begin{array}{l}4.0 \\
4.8 \\
5.5 \\
2.1 \\
\end{array}$ \\
\hline 3.9 & 15.5 & 72.5 & 61.5 & 23.5 & 176.9 \\
\hline $\begin{array}{l}0.5 \\
0\end{array}$ & $\begin{array}{l}2.0 \\
1.0\end{array}$ & $\begin{array}{r}2.0 \\
15.0\end{array}$ & $\begin{array}{r}2.0 \\
13.3\end{array}$ & $\begin{array}{l}1.0 \\
0.9\end{array}$ & $\begin{array}{r}7.5 \\
30.2\end{array}$ \\
\hline $\begin{array}{l}0 \\
0 \\
0\end{array}$ & $\begin{array}{l}3.0 \\
0 \\
0.6\end{array}$ & $\begin{array}{r}45.0 \\
0.6 \\
1.0\end{array}$ & $\begin{array}{r}32.1 \\
3.0 \\
2.0\end{array}$ & $\begin{array}{l}1.0 \\
8.0 \\
0.9\end{array}$ & $\begin{array}{r}81.1 \\
11.6 \\
4.5\end{array}$ \\
\hline $\begin{array}{l}0 \\
0 \\
0 \\
\end{array}$ & $\begin{array}{r}10.0 \\
1.0 \\
3.0 \\
\end{array}$ & $\begin{array}{r}5.0 \\
2.2 \\
13.0 \\
\end{array}$ & $\begin{array}{l}8.0 \\
2.2 \\
9.1 \\
\end{array}$ & $\begin{array}{r}14.0 \\
1.4 \\
2.7 \\
\end{array}$ & $\begin{array}{r}37.0 \\
6.8 \\
27.8 \\
\end{array}$ \\
\hline 0.5 & 20.6 & 83.8 & 71.7 & 29.9 & 206.5 \\
\hline 4.4 & 36.1 & 156.3 & 133.2 & 53.4 & 383.4 \\
\hline
\end{tabular}

(a) Rounded to the next higher 0.1 man-year.

(b) Includes an additional 4 months following active decommissioning in order to complete the documentation and other unspecified license and contract termination requirements.

(c) Based on one operator per shift in the control room, three shifts per day, 7 days per week.

(d) Based on 10 CFR Part 73 and information obtained from Washington Public Power Supply System; includes both response and access contrnl personnel on a three-shift, 7-day-week basis.

(e) Requirements during the 3 years, following final reactor shutcown are based on Figure J.4-7, unless otherwise noted; individual man-month requirements in Figure J.4-1 are rounded to the next higher 1.0 man-month in calculating these requirements.

(f) Based on a constant loading of 15 people tlirough month 22 following reactor shutdown, with additional personnel added as required to meet schedule demands during that period, and diminishing thereafter as the schedule allows.

(g) Based on constant loadings of 45 people through month 12 following final reactor shutdown and 35 people from month 13 through month 23 , and diminishing thereafter as the schedule allows.

(h) Based on a constant loading of 13 people through month 18 following reactor shutdown, with additional personnel added as required to meet schedule demands during that period, and diminishing thereafter as the schedule allows except during months 29 and 30 when 10 trained people are required to meet the schedule requirements. 
that balances the costs of surveillance and maintenance against the decreased dismantlement costs and land use values, as well as by societal or regulatory issues.

\subsubsection{Quality Assurance}

A modest quality assurance program is anticipated to be carried on throughout the continuing care period to assure that the surveillance, security, and maintenance work does not endanger public safety or the safety of the continuing care staff. This program also assures that all applicable quality assurance, quality control, and record-keeping regulations and requirements are met.

\subsubsection{Environmental Surveillance}

An abbreviated version of the environmental monitoring program conducted during plant operation is carried out during continuing care. The purpose of this program is to identify and quantify releases of radioactivity to the environment. Details of this program, including the anticipated requirements, are discussed in Section G.6 of Appendix G.

\subsubsection{Security}

The protection of the public, principally against the consequences of their own actions, is an important dimension of the security program during the continuing care period of passive safe storage. Conventional security detection and notification systems normally used to protect the utility against loss or damage are augmented by audible alarms. These alarms, strategically located outside secured radiation zones, loudly warn an intruder of his potential danger. Silent sensors simultaneously alert offsite security personnel.

Physical security to prevent inadvertent radiation exposure of continuing care personnel is provided by multiple-locked barriers. The presence of these barriers makes unauthorized entry in to areas where radiation or contamination is present extremely difficult. Locks on the gates in the fence around the facility provide the first line of security. The fence is maintained in good condition throughout the continuing care period. Facility security is maintained at all times by intrusion alarms and high-security locks on exterior doors. Intrusion, fire, and radiation detection systems are remotely monitored 
by an offsite commercial security agency. Security agency personnel respond immediately or summon assistance as necessary, depending on the situation indicated by the detection system alarms.

Routine patrol checks by onsite guards are not considered to be costeffective. By contracting for the services of a reputable private security agency, the facility owner is assured of adequate surveillance and prompt response to alarms without overloading the local law enforcement unit. Liaison with local law enforcment agencies is maintained and their assistance called for only when necessary.

A representative, who is responsible for controlling authorized access into and movement within the facility, is designated by the utility (see Section 9.2 .5 .5$)$.

\subsubsection{Essential Systems and Services Requirements}

Systems and services required during continuing care are listed in Table J.2-2 in Appendix $\mathrm{J}$, together with the justification for retaining each.

\subsubsection{Continuing Care Staff Requirements}

The staff organization shown in Figure 9.2-3 takes over the surveillance, maintenance, and security tasks for the duration of the continuing care period. The surveillance and maintenance is supervised by one part-time employee known as the surveillance and maintenance representative. In addition to controlling authorized access into and movement within the facility, he is charged with the responsibilities of appropriate actions and notifications regarding breaches of security, upkeep of plant surveillance and maintenance programs, and administrative reporting of these events as required by state and federai regulations.

\subsection{ENTOMBMENT ACTIVITIES AND MANPOWER REQUIREMENTS}

The entombment mode of decommissioning may require continuation of the utility's possession-only license in perpetuity, unless the long-lived radioactivity is removed initially or the entombment structure is reopened and the materials stored inside are surveyed and released or shipped to a disposal site. In the first few years after final reactor shutdown, entombment results in occupational radiation exposures and costs significantly greater than 


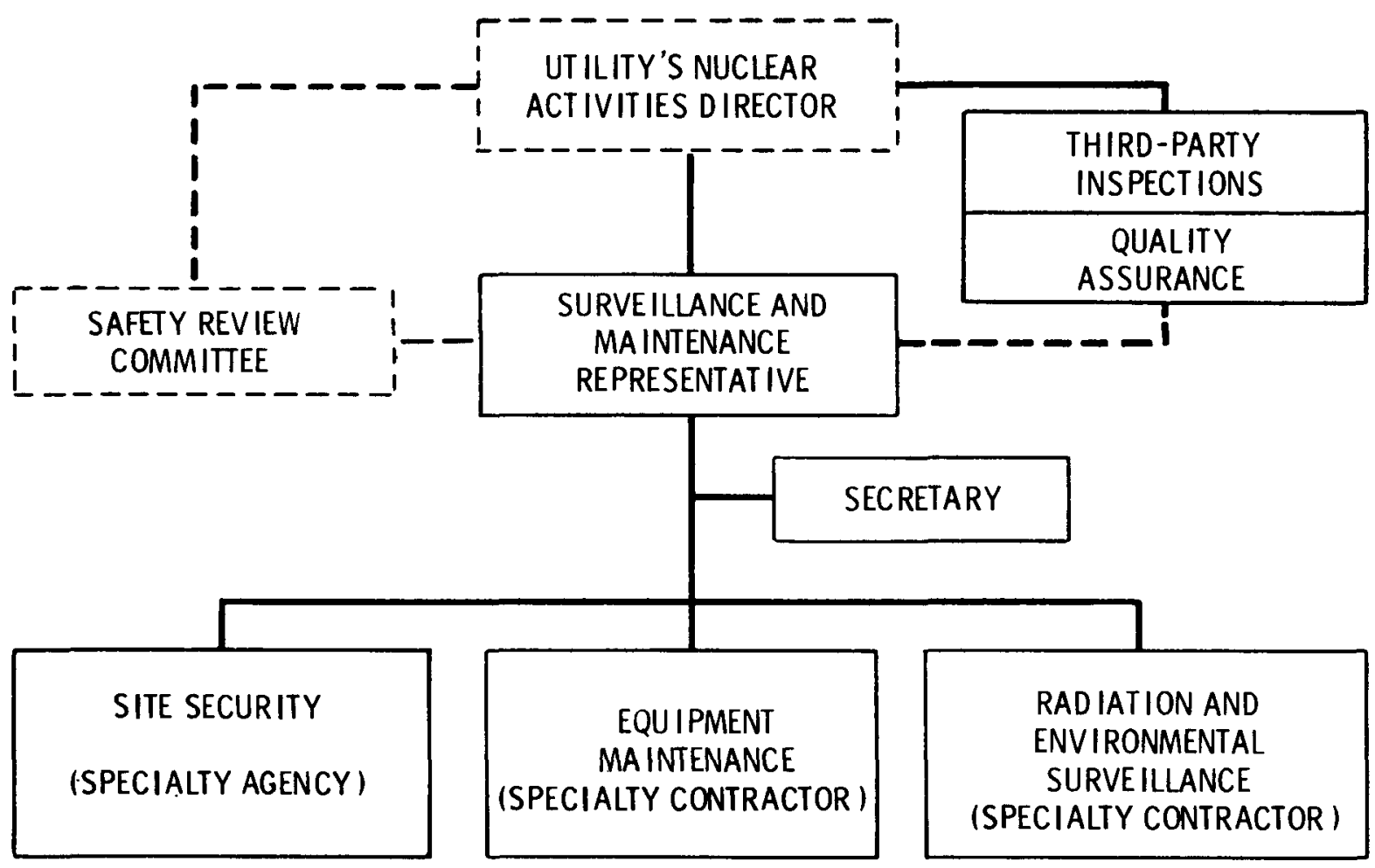

FIGURE 9.2-3. Staff Organization for the Passive Safe Storage Continuing Care Period

those for passive safe storage but somewhat less than those for immediate dismantlement. Planning and preparation, entombment activities, and the schedules and manpower requirements for entombment of the reference BWR are discussed in the following subsections.

\subsubsection{Planning and Preparation Activities}

Entombment of the reference BWR is a complex undertaking and, consequently, the success of the project is greatly dependent upon good planning and upon completion of preparatory work before final reactor shutdown. Planning and preparation for entombment is assumed accomplished during the 2 years prior to final reactor shutdown.

The planning and preparation activities for entombment are essentially the same as those described in Section 9.1.1 for immediate dismantlement and are not discussed further here. 


\subsubsection{Entombment Activities}

The major activities and requirements to accomplish entombment of the reference BWR are:

- decontamination

- preparation of the entombment structure

- disassembly and disposition of radioactive materials

- quality assurance

- environmental surveillance

- specialty contractors

- essential systems and services.

These activities are discussed in the following subsections.

\subsubsection{Decontamination}

At final reactor shutdown, significant radioactive contamination is present on the surfaces of process systems and equipment. Decontamination is relied upon to remove the bulk of this radioactive contamination from selected systems and components. The objective of the decontamination effort during entombment is to reduce the radiation levels throughout the facility in order to minimize personnel exposure during subsequent tasks. Two system decontamination methods are used: chemical decontamination and water-jet cleaning.

The decontamination activities required for entombment are identical to those for immediate dismantlement, as discussed in Section 9.1.2.1, and are not discussed further here.

\subsubsection{Preparation of the Entombment Structure}

The postulated entombment structure for the reference BWR is the steel primary containment vessel enclosed with the concrete biological shield, both of which rest on the Reactor Building foundation mat. All penetrations through the vessel and the shield are sealed. Inside the vessel, plates are welded over the equipment and personnel access openings and the stub ends of cut-off piping. Openings in the biological shield are then filled with reinforced concrete. Finally, the removable concrete Primary Containment head plugs are grouted in place. In addition, new hatches are cut through the drywell floor 
to facilitate the placement of radioactive materials in the wetwell. All of this work is carried out concurrently with the placement of radioactive materials inside the structure. Preparation of the entombment structure is discussed in detail in Seection K.1.2 of Appendix K (Volume 2).

To provide a secondary barrier around the entombment structure, the Reactor Building is assumed to be left standing and is sealed to prevent unauthorized access after the entombment structure is filled and sealed. The steam tunnel and railroad tunnel are sealed with reinforced concrete. All but one of the external building doors are welded shut; the remaining door is locked and fitted with an intrusion-alarm device. Additional intrusion alarms and other surveillance equipment are installed in strategic locations throughout the building.

\subsubsection{Disassembly and Disposition of Radioactive Materials}

Two entombment scenarios, both using the entombment structure described above, are considered in this study. In scenario 1, the neutron-activated reactor vessel internals are removed and shipped offsite for disposal. In scenario 2, the reactor vessel internals are left in place. In both scenarios, as much as possible of the radioactive material in the plant is placed within the entombment structure. However, there is insufficient room in the entombment structure for all contaminated materials, so both scenarios require some waste to be packaged and shipped offsite for disposal.

The disassembly and disposition of materials is carried out in the same manner as that described for immediate dismantlement (see Section 9.1.2.2) with two exceptions: 1) only part of the radioactive materials resulting from entombment require offsite disposal, and 2) only a minor amount of disassembly work is carried out inside the primary containment vessel.

The first exception is described previously and is not discussed further here. Additional details concerning the entombment structure's capacity for waste and the amount of material assumed to be shipped offsite are presented in Sections K.1.3 and K.3.1 of Appendix K.

The second exception results from the use of the primary containment vessel as the entombment structure. Radioactive materials already present in the vessel do not require disassembly and removal. However, some disassembly is performed. 
Short lengths of the piping penetrating the vessel are removed to allow sealwelding of the penetrations at the vessel wall. In addition, wetwell downcomer pipes and some floor gratings and associated framework are removed to facilitate placement of contaminated materials inside the structure and to allow more efficient use of the structure's internal volume.

Disassembly techniques are described generically in Appendix G. A detailed discussion of entombment is presented in Section K. 1 of Appendix K.

\subsubsection{Quality Assurance}

An extensive quality assurance program is carried on throughout the decommissioning effort, to ensure that all applicable regulations are met, that the work is performed according to plan, and that the work does not endanger the safety of the public or of the decommissioning staff. The quality assurance program for entombment is essentially the same as that for immediate dismantlement, as described in Section 9.1.2.3. A more detailed review of the anticipated elements of an appropriate quality assurance program for entombment is given in Section G.5 of Appendix G.

\subsubsection{Environmental Surveillance}

An abbreviated version of the environmental monitoring program carried on during plant operation is continued during the entombment period. This program is the same as that for immediate dismantlement (see Section 9.1.2.4). Details of the program are discussed in Section G.6 of Appendix G.

\subsubsection{Specialty Contractors}

The specialty contractors required during entombment of the reference BWR are:

- environmental monitoring specialists, for implementing the environmental surveillance program previously discussed

- hauling contractors, for transport of packaged radioactive materials to a disposal site

- temporary radwaste handling and solidification support, for radwaste handling and final cleanup after the installed radwaste handling systems are decontaminated. 
If, following entombment, excess facility structures are demolished and the site restored, demolition and landscaping contractors are also required.

\subsubsection{Essential Systems and Services}

All or parts of certain facility systems and services must remain in place and in service until all radioactive material is either removed from the facility or secured on the site, to prevent the release of significant quantities of radionuclides (or other hazardous materials) to the environment. Some systems and services are required for cleanup and disassembly activities, and others provide personnel health and safety protection. The systems and services essential for entombment are the same as those given in Section 9.1.2.6 for immediate dismantlement.

\subsubsection{Entombment Schedule}

The schedule and sequence of scenario-l entombment tasks is shown in Figure 9.3-1. Further schedule details are presented in Section K.2 of Appendix $\dot{K}$. The schedule for scenario-2 entombment is the same except for the deletion of three tasks in the Reactor Building: 1) remove dryer and separator, 2) remove reactor vessel internals, and 3) ship activated components. These deletions do not affect the other tasks or the overall length of the schedule because they are not critical path items.

$\mathrm{Pl}$ anning and preparation (see Section 9.3.1) begins about 2 years before final shutdown of the reactor. After final shutdown, the reactor is disabled and defueled as required to obtain a possession-only license. The spent fuel is shipped to an offsite location after an initial 120-day cooling period. Initial efforts are directed at draining contaminated systems, and equipment disassembly begins with removal of the reactor vessel internals and removal of the turbine. Disassembly of equipment in the Radwaste and Control Building is delayed until nearly all of the contaminated water from the other buildings has been processed. As indicated in Figure 9.3-1, entombment is completed in about 47 months. 
•।

• 


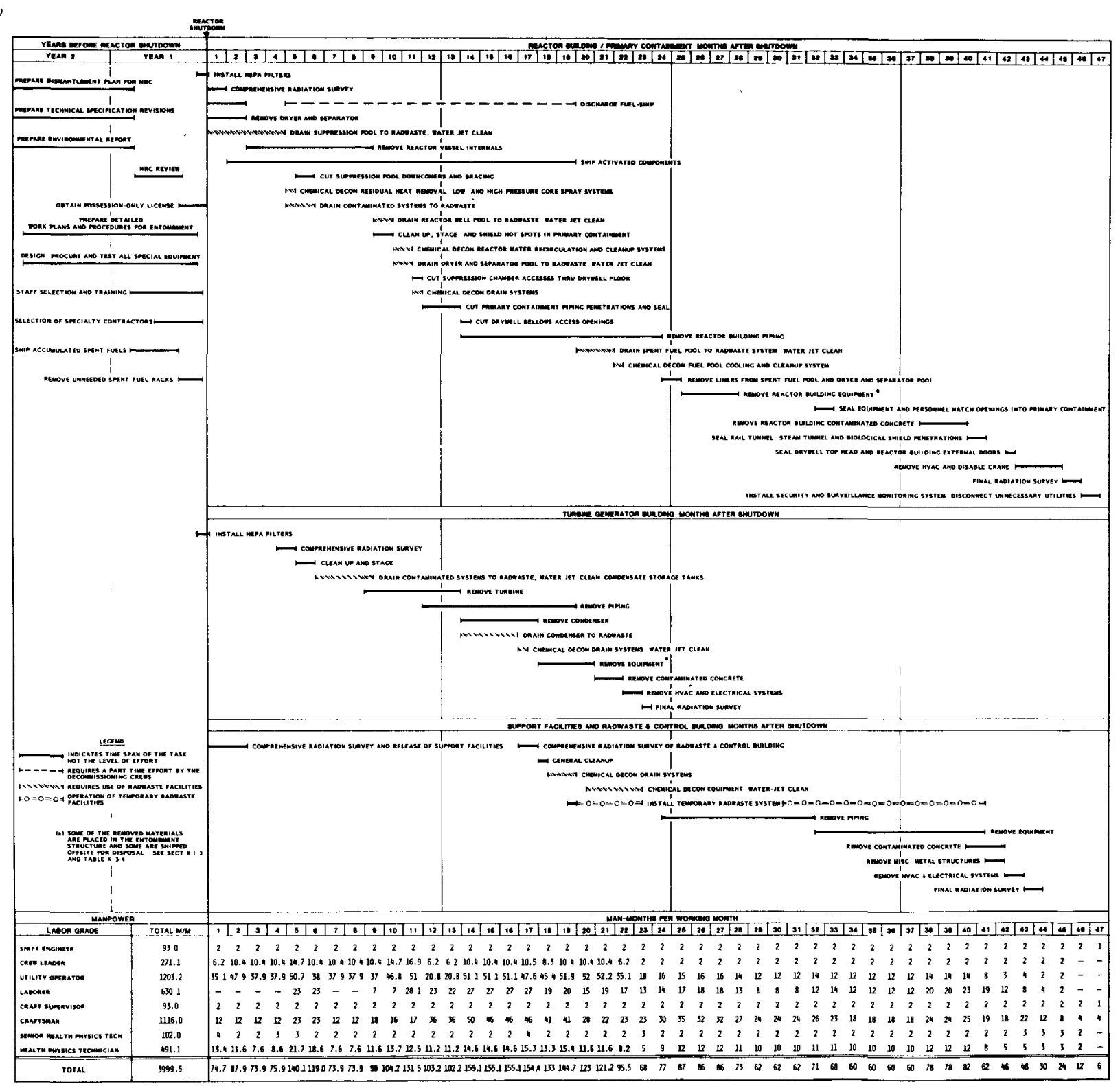

FIGURE 9.3-1. Overall ScheduTe and Sequence and Decommissioning Worker Requirements for Scenario-
Entombment Tasks

$9-43$

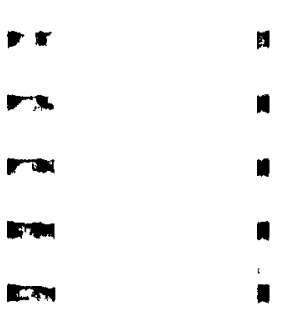

in

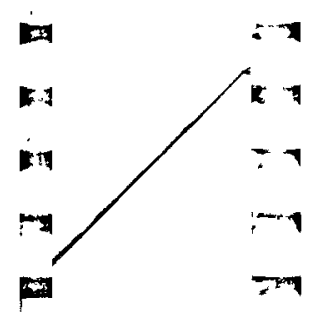

3
1
7
7
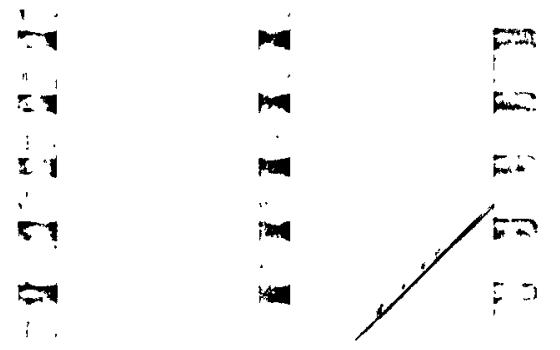



\subsubsection{Entombment Staff Requirements}

The organization of the entombment decommissioning staff and the functions of the various staff members are the same as those for immediate dismantlement, as shown in Figure 9.1-2 and discussed in Section 9.1.4.1.

Estimates of manpower requirements are based on the entombment schedule and take into account both radiation exposure limits and actual manpower needed to complete the individual tasks. The estimated number of decommissioning workers of each category is shown for each month of entombment at the bottom of Figure 9.3-1. A total of about 4000 man-months of "hands-on" effort is required. This total, however, does not include the extra manpower maintained during certain periods of time to meet peak demands later in the project.

Total staff labor requirements for scenario-l entombment of the reference BWR are given in Table 9.3-1. The requirements are given in equivalent man-years for the 2 years before and the 4 years following final reactor shutdown, and include the management and support staff as well as the decommissioning workers. A total effort of about 630 man-years is estimated for completion of scenario 1. For scenario-2 entombment, the total staff labor requirement is just over 590 man-years.

The manpower requirements for entombment are discussed in detail in Section K.2 of Appendix K.

\subsection{DEFERRED DISMANTLEMENT ACTIVITIES AND MANPOWER REQUIREMENTS}

Deferred dismantlement achieves the degree of decontamination necessary for termination of the possession-only license for the reference BWR after some period of safe storage or entombment. The facility and site must be shown to have residual radioactivity levels low enough to permit unrestricted use.

The same basic operations are assumed performed during deferred dismantlement as are performed during immediate dismantlement. The reactor vessel internals have sufficiently high radiation dose rates to require disassembly and sectioning under water, even after a 100-year decay period, due to the presence of ${ }^{94} \mathrm{Nb}$. Thus, the same semi-remote cutting techniques are employed. Similarly, portions of the reactor vessel may be sufficiently radioactive to require 


\section{TABLE 9.3-1. Staff Labor Requirements for Scenario-1 Entombment}

\begin{tabular}{|c|c|c|c|c|c|c|c|}
\hline \multirow[b]{2}{*}{ Management and Support Staff } & \multicolumn{6}{|c|}{$\begin{array}{l}\text { Time Relative to Final Reactor Shutdown (year) } \\
\frac{-2}{\frac{-1}{\text { Annual }}} \frac{1}{\text { Staff Labor Requirement } \frac{2}{3}} \frac{4}{\text { (man-years)(a) }}\end{array}$} & \multirow[t]{2}{*}{$\begin{array}{l}\text { Total S } \\
\text { Labor Re } \\
\text { (man-ye }\end{array}$} \\
\hline & & & & & & & \\
\hline $\begin{array}{l}\text { Decommissioning Superintendent } \\
\text { Secretary } \\
\text { Clerk }\end{array}$ & $\begin{array}{l}0.3 \\
1.0 \\
0\end{array}$ & $\begin{array}{l}1.0 \\
2.0 \\
1.0\end{array}$ & $\begin{array}{l}1.0 \\
3.0 \\
2.0\end{array}$ & $\begin{array}{l}1.0 \\
3.0 \\
2.0\end{array}$ & $\begin{array}{l}1.0 \\
3.0 \\
2.0\end{array}$ & $\begin{array}{l}1.2(\mathrm{~b}) \\
2.4(\mathrm{~b}) \\
0.9\end{array}$ & $\begin{array}{r}5.5 \\
14.4 \\
7.9\end{array}$ \\
\hline $\begin{array}{l}\text { Decommissioning Engineer } \\
\text { Assistant Decomissioning Engineer } \\
\text { Radioactive Shipment Specialist }\end{array}$ & $\begin{array}{l}1.0 \\
1.0 \\
0\end{array}$ & $\begin{array}{l}1.0 \\
1.0 \\
1.0\end{array}$ & $\begin{array}{l}1.0 \\
1.0 \\
1.0\end{array}$ & $\begin{array}{l}1.0 \\
1.0 \\
1.0\end{array}$ & $\begin{array}{l}1.0 \\
1.0 \\
1.0\end{array}$ & $\begin{array}{l}1.2^{\text {(b) }} \\
0.7 \\
0.7\end{array}$ & $\begin{array}{l}6.2 \\
5.7 \\
4.7\end{array}$ \\
\hline $\begin{array}{l}\text { Procurement Specialist } \\
\text { Tool Crib Attendant } \\
\text { Control Room Operator (c) }\end{array}$ & $\begin{array}{l}0.3 \\
0 \\
0\end{array}$ & $\begin{array}{l}1.0 \\
0 \\
0\end{array}$ & $\begin{array}{l}1.0 \\
2.0 \\
5.0\end{array}$ & $\begin{array}{l}1.0 \\
2.0 \\
5.0\end{array}$ & $\begin{array}{l}1.0 \\
2.0 \\
5.0\end{array}$ & $\begin{array}{l}0.7 \\
1.4 \\
3.6\end{array}$ & $\begin{array}{r}5.0 \\
7.4 \\
18.6\end{array}$ \\
\hline $\begin{array}{l}\text { Security Supervisor } \\
\text { Security Shift Superyisor (d) } \\
\text { Security Patrolman(d) } \\
\text { Contracts and Accounting Specialist }\end{array}$ & $\begin{array}{l}0 \\
0 \\
0 \\
0.3\end{array}$ & $\begin{array}{l}0 \\
0 \\
0 \\
1.0\end{array}$ & $\begin{array}{r}1.0 \\
5.0 \\
39.0 \\
1.0\end{array}$ & $\begin{array}{r}1.0 \\
5.0 \\
28.0 \\
1.0\end{array}$ & $\begin{array}{r}1.0 \\
5.0 \\
13.0 \\
1.0\end{array}$ & $\begin{array}{l}0.9 \\
4.4 \\
11.4 \\
1.2(b)\end{array}$ & $\begin{array}{r}3.9 \\
19.4 \\
91.4 \\
5.5\end{array}$ \\
\hline $\begin{array}{l}\text { Health and Safety Supervisor } \\
\text { Health Physicist } \\
\text { Protective Equipment Attendant } \\
\text { Industrial Safety Specialist }\end{array}$ & $\begin{array}{l}1.0 \\
0 \\
0 \\
0.3\end{array}$ & $\begin{array}{l}1.0 \\
0.5 \\
0 \\
1.0\end{array}$ & $\begin{array}{l}1.0 \\
1.0 \\
2.0 \\
1.0\end{array}$ & $\begin{array}{l}1.0 \\
1.0 \\
2.0 \\
1.0\end{array}$ & $\begin{array}{l}1.0 \\
1.0 \\
2.0 \\
1.0\end{array}$ & $\begin{array}{l}1.2^{(b)} \\
0.8 \\
1.8 \\
0.9\end{array}$ & $\begin{array}{l}6.2 \\
4.3 \\
7.8 \\
5.2\end{array}$ \\
\hline $\begin{array}{l}\text { Quality Assurance Supervisor } \\
\text { Quality Assurance Engineer } \\
\text { Quality Assurance Technician } \\
\text { Consultant (Safety Review) } \\
\end{array}$ & $\begin{array}{l}0.3 \\
0.5 \\
0 \\
\underline{0.5} \\
\end{array}$ & $\begin{array}{l}1.0 \\
2.0 \\
0.5 \\
0.5 \\
\end{array}$ & $\begin{array}{l}1.0 \\
1.0 \\
4.0 \\
0.5 \\
\end{array}$ & $\begin{array}{l}1.0 \\
1.0 \\
4.0 \\
\underline{0.5} \\
\end{array}$ & $\begin{array}{l}1.0 \\
1.0 \\
4.0 \\
0.5 \\
\end{array}$ & $\begin{array}{l}1.2^{(b)} \\
0.9 \\
3.5 \\
\underline{0.5} \\
\end{array}$ & $\begin{array}{r}5.5 \\
6.4 \\
16.0 \\
3.0 \\
\end{array}$ \\
\hline Subtotals, Management and Support Staff & $\underline{6.5}$ & $\underline{15.5}$ & $\underline{74.5}$ & $\underline{63.5}$ & $\underline{48.5}$ & $\underline{41.5}$ & $\underline{250.0}$ \\
\hline \multicolumn{8}{|l|}{ Decommissioning Workers $(e)$} \\
\hline $\begin{array}{l}\text { Shift Engineer } \\
\text { Crew Leader(f) }\end{array}$ & $\begin{array}{l}1.0 \\
0\end{array}$ & $\begin{array}{l}2.0 \\
0.7\end{array}$ & $\begin{array}{r}2.0 \\
12.2\end{array}$ & $\begin{array}{l}2.0 \\
9.2\end{array}$ & $\begin{array}{l}2.0 \\
2.0\end{array}$ & 1.8 & $\begin{array}{l}10.8 \\
25.6\end{array}$ \\
\hline $\begin{array}{l}\text { Utility Operator }(g) \\
\text { Laborer } \\
\text { Craft Supervisor }\end{array}$ & $\begin{array}{l}0 \\
0 \\
0\end{array}$ & $\begin{array}{l}3.0 \\
0 \\
0.6\end{array}$ & $\begin{array}{r}52.0 \\
9.4 \\
2.0\end{array}$ & $\begin{array}{r}44.9 \\
20.6 \\
2.0\end{array}$ & $\begin{array}{r}14.5 \\
12.7 \\
2.0\end{array}$ & $\begin{array}{r}6.3 \\
10.0 \\
1.8\end{array}$ & $\begin{array}{r}120.7 \\
52.7 \\
8.4\end{array}$ \\
\hline $\begin{array}{l}\text { Craftsman } \\
\text { Senior Health Physics Technjcian } \\
\text { Health Physics Technician }(h) \\
\end{array}$ & $\begin{array}{l}0 \\
0 \\
0\end{array}$ & $\begin{array}{r}10.0 \\
1.0 \\
3.0 \\
\end{array}$ & $\begin{array}{r}17.1 \\
2.4 \\
13.9 \\
\end{array}$ & $\begin{array}{r}36.0 \\
2.3 \\
13.6 \\
\end{array}$ & $\begin{array}{r}25.1 \\
2.0 \\
12.0 \\
\end{array}$ & $\begin{array}{r}14.9 \\
2.0 \\
6.2 \\
\end{array}$ & $\begin{array}{r}103.1 \\
9.7 \\
48.7 \\
\end{array}$ \\
\hline Subtotals, Decommissioning Workers & $\underline{1.0}$ & $\underline{20.3}$ & 111.0 & 130.6 & 72.3 & $\underline{44.5}$ & $\underline{379.7}$ \\
\hline Totals & 7.5 & 35.8 & 185.5 & 194.1 & 120.8 & 86.0 & 629.7 \\
\hline
\end{tabular}

(a) Rounded to the next higher 0.1 man-year.

(b) Includes 4 additional months following active decomissioning in order to complete the documentation and other unspecified license and contract termination requirements; shown as part of the fourth year, even though it extends 2.5 months into the fifth year.

(c) Based on one operator per shift in the control room, three shifts per day, 7 days per week.

(d)Based on 10 CFR Part 73 and information obtained from Washington Public Power Supply System; includes both response and access-control personnel on a three-shift, 7-day-week basis.

(e) Requirements during the 4 years following reactor shutdown are based on manpower values in Figure K.2-1, unless otherwise noted; individual man-month requirements in the figure are rounded to the next higher 1.0 man-month in calculating these requirements.

(f)Based on a constant loading of 11 people through month 21 following reactor shutdown, with additional personnel added as required to meet schedule demands during that period, and diminishing thereafter as the schedule allows.

(g)Based on a constant loading of 52 people through month 21 following reactor shutdown, diminishing thereafter as the schedule allows except during months 29 through 37 when 14 trained personnel are maintained to meet the requirements during months 38 through 40 .

(h)Based on a constant loading of 12 people through month 40 following reactor shutdown, with additional personnel added as required to meet schedule demands during that period. 
sectioning using semi-remote equipment, especially for decay periods of 50 years or less. Portions of the concrete in the biological shield will remain radioactive for long periods of time, due to the presence of activated trace elements, such as ${ }^{152} \mathrm{Eu}$ and ${ }^{154} \mathrm{Eu}$, and will have to be removed for packaging and burial. The radioactive corrosion products on the inner surfaces of the piping, tanks, etc., consist mostly of ${ }^{60} \mathrm{Co}$. Even though these systems are chemically decontaminated during preparations for passive safe storage, it is unlikely that the residual radioactivity will decay to levels that permit unrestricted use before 50 years have elapsed. All of the systems have to be disassembled to make measurements on the interior surfaces of the systems to determine whether the material can be released or must be buried, regardless of the length of the safe storage period.

Operations such as reactor defueling and shipment of spent fuel, chemical decontamination of the fluid systems, and removal of radioactive wastes such as cartridge filters, ion exchange resins, and evaporator bottoms liquids are performed during preparations for safe storage and are not required during deferred dismantlement. These activities are replaced by extensive training and familiarization of the decommissioning staff with the facility, since the staff cannot be made' up of personnel from the operations staff after an extended period of passive safe storage. Additional effort is required to restore the services needed for dismantlement throughout the station and to remove the the various locks, welded closures, and barricades that were installed to secure the station during preparations for passive safe storage.

In view of the above considerations, it is reasonable to assume that a work force of the same size as utilized for immediate dismantlement is required for deferred dismantlement, and over approximately the same period of time. Other assumptions made in this study with regard to deferred dismantlement are:

- If dismantlement is performed sooner than 50 years after reactor shutdown, all of the systems and materials are still too radioactive to be released for unrestricted use. The same volumes of material must be removed and transported to a burial site. 
- After 50 years of passive safe storage, the only contamination remaining in the facility is the accumulation of fission products on the surfaces of isolated, shielded cells (ion exchange vaults). The amount of contaminated material for disposal is reduced to $150 \mathrm{~m}^{3}$ or less. The activated corrosion products in the piping systems and on the nonactivated components decay sufficiently to permit unrestricted use of those materials.

\subsubsection{Work Schedule Estimates}

Since the same basic efforts are required to dismantle a plant regardless of when the dismantlement takes place, the work schedules presented in Figure 9.1-1 for immediate dismantlement are assumed to be valid. Operations such as reactor defueling, fuel shipment, and chemical decontamination are replaced by familiarization and orientation of the work force with the facility, by training, and by restoring essential services and unsecuring the facility.

\subsubsection{Deferred Dismantlement Staff Requirements}

The management and support staff requirements are the same for deferred dismantlement as they are for immediate dismantlement. However, fewer decommissioning workers are required for deferred dismantlement than for immediate dismantlement, since the radiation dose rates are lower when dismantlement is deferred. Since the occupational radiation dose is lower because of radioactive decay, the extra workers needed to meet the occupational dose limits during immediate dismantlement are not needed for deferred dismantlement. 


\section{DECOMMISSIONING COSTS}

The costs for accomplishing the decommissioning of the reference BWR by immediate dismantlement, passive safe storage, and entombment are developed in detail in Appendices I, J, and $\mathrm{K}$ in Volume 2, respectively. They are summarized in the following sections.

The principal assumptions made in the generation of cost estimates for the decommissioning of the reference BWR are:

- The decommissioning staff is drawn from the technical and operations staffs of the plant to the maximum extent possible. Thus, all support services and the part-time assistance of many plant staff members can be utilized during the planning and preparation period, with only nominal costs to the decommissioning program.

- The possession-only license is in place by final reactor shutdown, permitting decommissioning activities to begin promptly.

- Chemical decontamination of the selected systems and equipment permits the decommissioning staff to work in direct contact with these systems.

- Pool liners and most piping and equipment in the Reactor Building, the Turbine Generator Building, and the radwaste area are contaminated and require packaging for shipment to a burial site.

- Costs are based on early 1978 prices and wage rates.

\subsection{COSTS FOR IMMEDIATE DISMANTLEMENT}

The estimated cost for immediate dismantlement of the reference BWR, including a $25 \%$ contingency, is $\$ 43.6$ million, as summarized in Table 10.1-1. Details of the development of these costs are discussed in Section I.3 of Appendix I.

Other possible immediate dismantlement requirements (i.e., spent fuel shipment, facility demolition and site restoration, deep geologic disposal of 
TABLE 10.1-1. Summary of Estimated Costs for Immediate Dismantlement

\section{Cost Category}

Disposal of Radioactive Materials

Neutron-Activated Materials

Contaminated Materjag]s

Total Disposal Costs

Staff Labor

Energy

Special Tools and Equipment

Miscellaneous Supplies

Specialty Contractors $(e)$

Nuclear Insurance

License Fees

Subtotal

Contingency (25\%)

Total, Immediate Dismantlement Costs

Spent Fuel Shipment

Facility Demolition and Site Restoration

Deep Geologic Disposal of Highly Activated Materiars

Fuel Channel Disposal

Subtotal

Contingency (25\%)

Total, Other Possible Costs

\begin{tabular}{ll}
$\begin{array}{c}\text { Estimated Costs } \\
\text { (\$millions) }(\mathrm{a}, \mathrm{b})\end{array}$ & $\begin{array}{l}\text { Percent } \\
\text { Total }(c)\end{array}$ \\
\hline
\end{tabular}

2.300

4.909

1.469

\begin{tabular}{rr}
8.678 & 24.9 \\
17.561 & 50.4 \\
3.519 & 10.1 \\
2.016 & 5.8 \\
& \\
1.859 & 5.3 \\
0.356 & 1.0 \\
0.800 & 2.3 \\
0.051 & 0.1 \\
\hline 34.840 & 100.0 \\
\hline 8.710 & \\
\hline$\underline{43.550}$ & \\
\hline
\end{tabular}

$3.788^{(f)}$

13.244

$0.848^{(g)}$

$0.617^{(h)}$

18.497

4.624

23.121

(a) Costs adjusted to early 1978.

(b) The number of significant figures shown is for computational completeness and does not imply accuracy to the nearest $\$ 1000$.

(c) Individually rounded to the nearest $0.1 \%$.

(d) Includes both wet solid wastes and dry solid wastes.

(e) Includes explosives, temporary radwaste, and environmental monitoring services.

(f)Does not include costs for handling at the reactor or costs for handling and storage at the repository; if required, shipment by special train costs an additional estimated $\$ 2.451$ million, maximum.

(g) Incremental cost in addition to the cost for shallow-land disposal of these materials; the maximum additional cost for shipment by special train is estimated at $\$ 1.254$ million.

(h)Alternate deep geologic disposal costs an estimated $\$ 1.047$ million; shipment by special train to the deep geologic disposal facility increases this cost by an estimated maximum cost of $\$ 0.456$ million. 
highly activated materials, and fuel channel disposal) are estimated to cost about $\$ 23$ million, including a $25 \%$ contingency.

\subsubsection{Costs for Disposal of Radioactive Materials}

Three types of radioactive materials in the reference BWR that require disposal are 1) neutron-activated materials, 2) contaminated materials, and 3 ) radioactive wastes. The total cost for disposal of these materials is about $\$ 8.7$ million and is approximately $25 \%$ of the total immediate dismantlement cost. The disposal cost includes the container, transportation, and burial costs but not the direct labor costs for removing and packaging the materiais.

The neutron-activated materials are contained in the reactor vesse1, the vessel internals, and the sacrificial shield, and are located inside Primary Containment. Details of the disposal of the neutron-activated materials are given in Table I.3-3 in Appendix I. The total radioactivity estimated to be present in the neutron-activated materials is approximately 6.6 million curies. The packaged materials require an estimated 317 overweight truck shipments and occupy $228 \mathrm{~m}^{3}$ of space in a shallow-land burial facility. The total estimated cost for disposal of the neutron-activated materials in a shallow-land burial facility is about $\$ 2.3$ million.

Contaminated materials in the reference BWR are assumed to include much of the piping and equipment located in the Reactor Building/Primary Containment, the Turbine Generator Building, and the Radwaste and Control Building. In addition, many concrete surfaces in these three buildings are assumed to be contaminated, thus requiring surface removal to a depth of about $0.05 \mathrm{~m}$. Breakdowns of the disposal costs for contaminated materials are given in Table I.3-4 in Appendix I. Approximately 8600 curies (see Section E.2 of Appendix $E$ in Volume 2) of radioactivity are removed with the contaminated materials. These materials require an estimated 806 truck shipments to and an estimated $17,219 \mathrm{~m}^{3}$ of space (including the disposable containers, as required) at a shallow-land burial site. The total disposal cost for contaminated materials from the reference BWR is about $\$ 4.91$ million.

Twenty large, contaminated heat exchangers in the reference BWR require special segmenting for shipping and burial. These are the two RHR heat 
exchangers in the Reactor Building and the 14 low-pressure feedwater heaters, the two moisture separator reheaters, and the two high-pressure feedwater heaters in the Turbine Generator Building. To comply both with overweight shipping limits using standard vehicles and with burial site handling capabilities, these heat exchangers require segmenting into $4,42,26$, and 8 individually contained packages, respectively, as shown in Table 1.3-4 in Appendix I.

A savings can be made if the electropolishing decontamination system is successful in cleaning stainless steel and carbon steel components to unrestricted use levels, thus permitting salvage and sale of the decontaminated material. About $400 \mathrm{Mg}$ of stainless steel and $4300 \mathrm{Mg}$ of carbon steel are potentially salvageable. Using salvage values of $\$ 0.60$ per $\mathrm{kg}$ for stainless steel and $\$ 0.20$ per $\mathrm{kg}$ for carbon steel and the avoided disposal cost of $\$ 0.38$ per $\mathrm{kg}$, salvage of the contaminated stainless steel and carbon steel pipe and equipment gives a potential saving of $\$ 2.9$ million.

Radioactive wastes generated during dismantlement of the reference BWR are categorized as either wet solid waste or dry solid waste.

Wet solid wastes result from the processing of chemical decontamination solutions and contaminated water volumes. These wastes include concentrator bottoms, filter sludges, and spent demineralizer resins, as well as neutralized chemical solutions from decontamination of the contaminated drain systems. Wet solid wastes are assumed to be mixed with a cement solidifying agent and encapsulated in a steel cask liner prior to being shipped to a shallow-land burial facility. The disposal cost data for wet solid wastes generated during immediate dismantlement are contained in Table H.5-10 in Appendix H (Volume 2). An estimated 286 truck shipments and $816 \mathrm{~m}^{3}$ of burial space are required to dispose of the wet solid wastes, at a total cost of $\$ 1,073,400$.

Dry solid wastes include discarded, contaminated materials such as plastic sheeting, rags, and anticontamination clothing. They are expected to occur as a result of most of the tasks specified in Section I.2 of Appendix I and are estimated on a taskwise basis. The dry solid wastes are compacted as much as possible to reduce their volume. About $31 \%$ of the dry solid waste is assumed to require shielding during shipment, with the remainder shipped unshielded in 
closed trucks. An estimated 86 overweight truck shipments ( 72 shielded and 14 unshielded) are required to transport the compacted, packaged, dry solid wastes to a shallow-land burial facility, where they occupy an estimated $678 \mathrm{~m}^{3}$ of space. The total disposal cost for the dry solid wastes from immediate dismantlement is estimated at $\$ 395,650$.

\subsubsection{Costs for Staff Labor}

The costs for staff labor during immediate dismantlement are shown in detail in Table I.3-6 in Appendix I. More than 50\% of the total immediate dismantlement cost is associated with the staff labor requirements. A total staff labor cost of about $\$ 17.6$ million is estimated for immediate dismantlement of the reference BWR. Specialty contractor labor is not included in this total.

The dedicated manpower costs for the immediate dismantlement tasks are given in Table 1.3-7 in Appendix I. These costs are attributed to manpower that is specifically assigned to the tasks and do not include either nondedicated personnel or management and support staff (see Figure H.1-1 in Appendix H).

\subsubsection{Costs for Energy}

The costs for energy during immediate dismantlement are presented in Table I.3-8 in Appendix I, together with the estimated usage of both electricity and fuel oil. The usage of both energy forms is estimated based on a detailed analysis of the requirements for the essential systems and services and the immediate dismantlement tasks and schedule, presented in Table 9.1-1 and Figure 9.1-1 in Chapter 9, respectively.

A total of 106,400 MWh of electricity, costing $\$ 1,590,000$, and $14,570 \mathrm{~m}^{3}$ of fuel oil, costing $\$ 1,923,290$, are estimated to be used during immediate dismantlement. The total cost for energy is about $\$ 3.5 \mathrm{million}$ and represents about $10 \%$ of the total immediate dismantlement cost.

\subsubsection{Costs for Special Tools and Equipment}

The estimated costs for the special tools and equipment that are required for immediate dismantlement of the reference BWR are presented in Table I.3-9 in Appendix I. The estimated total cost for special tools and equipment is 
approximately $\$ 2.0$ million, which is approximately $6 \%$ of the total immediate dismantlement cost.

\subsubsection{Costs for Miscellaneous Supplies}

A variety of supplies are used during immediate dismantlement. These include expendable glass-fiber and HEPA filters, anticontamination clothing, cleaning and contamination control supplies, expendable hand tools, cutting and welding supplies, decontamination chemicals, and filter/demineralizer resins. The estimated costs for these items are given in Table 1.3-10 in Appendix I. The total estimated cost for miscellaneous supplies during immediate dismantlement of the reference BWR is about $\$ 1.9$ million and represents about $5 \%$ of the total immediate dismantlement cost.

\subsubsection{Costs for Specialty Contractors}

The estimated costs for specialty contractors are given in Table I.3-11 in Appendix I. As discussed in Section H.3 of Appendix H, these specialty contractors perform explosives work, temporary radwaste handling, and environmental monitoring. The costs for a hauling contractor are not shown in this table, but are shown as "transportation costs" in Section I.3.1 of Appendix I for disposal of radioactive wastes.

The total cost for specialty contractors during immediate dismantlement, excluding the hauling contractor, is $\$ 356,000$, which is about $1 \%$ of the total immediate dismantlement cost.

\subsubsection{Costs for Nuclear Insurance}

The costs for nuclear liability insurance during immediate dismantlement are estimated for an assumed policy limit of $\$ 125$ million carried through the dismantlement period. The total estimated cost for nuclear insurance is $\$ 800,000$, which represents about $2.3 \%$ of the total immediate dismantlement cost. 10.1.8 Costs for Licensing Fees

The fees charged for licensing services performed by the NRC are delineated in 10 CFR Part 170. (1) The costs for licensing fees during immediate dismantlement of the reference BWR are shown in Table I.3-13 in Appendix I. The total 
cost for licensing services is $\$ 50,800$, which is approximately $0.1 \%$ of the total immediate dismantlement cost.

\subsubsection{Other Possible Costs}

Four additional categories of costs could figure into the total immediate dismantlement cost, depending on how they are classified. In this study, these cost categories are presented separately, since they cannot be clearly identified as belonging to immediate dismantlement. The tasks that require these costs are:

- shipment of the spent reactor fuel to an offsite repository

- demolition of the structures and restoration of the site

- alternative disposal of the highly activated materials in a deep geologic disposal facility

- disposal of the fuel channels.

Since the ultimate disposition of the spent reactor fuel is not known, it is assumed in this study that the 764 fuel assemblies from the final reactor core load are shipped by rail, together with their fuel channels, to a repository located $2400 \mathrm{~km}$ from the reference BWR. The total estimated cost for shipping the spent fuel and channels to the repository is $\$ 3,788,000$. This does not include either handling costs at the reactor or handling and storage costs at the repository.

The costs for demolishing the decontaminated and uncontaminated structures of the reference BWR are summarized in Table L.3-1 in Appendix L (Volume 2). The total cost of $\$ 13,244,000$ (without contingency) includes labor, supplies, overheads, and profit, but not extraordinary insurance premium, bonding, or state sales tax. Details of cost estimates for this task are given in Section L. 3 of Appendix L.

The estimated disposal cost for the neutron-activated materials given in Table 10.1-1 is based on the assumption that all of these materials are placed in a shallow-land disposal site. If the amount of radioactivity in these neutron-activated materials is sufficiently great for them to be classified as intermediate-level wastes, they would have to be placed in a deep-geologic 
disposal facility. The incremental cost for disposing of these materials in a deep geologic disposal facility is $\$ 848,360$ greater than the shallow-land burial cost.

The assumption that the fuel channels are shipped and stored with the spent fuel is based on practicality rather than on present practice. Therefore, an analysis is needed to determine the alternative costs for disposing of the fuel channels either in a shallow-land disposal facility or in a deep-geologic disposal facility. The estimated costs for disposal of the fuel channels are $\$ 617,000$ for shallow-land burial disposal and $\$ 1,047,000$ for deep geologic disposal.

\subsection{COSTS FOR PREPARATIONS FOR PASSIVE SAFE STORAGE}

The estimated cost for preparations for passive safe storage, including a $25 \%$ contingency, is $\$ 21.29$ million, as summarized in Table 10.2-1. Details of the development of these costs are given in Section $\mathrm{J} .5$ of Appendix $\mathrm{J}$ (Volume 2).

A possible cost for preparations for passive safe storage--spent fuel shipment--is estimated to cost about $\$ 3.79$ million, not including a $25 \%$ contingency. If special trains are required, an additional cost of $\$ 2,451,000$ is necessary for 43 single-cask shipments (see Section M.4.2 of Appendix M). The use of more than one cask per shipment decreases this cost in proportion to the number of casks per train.

\subsubsection{Costs for Disposal of Radioactive Materials}

Both wet solid wastes and dry solid wastes require disposal during preparations for passive safe storage. The total cost for disposal of these materials is about $\$ 1.2$ million and is approximately $7 \%$ of the preparations cost. The disposal cost includes the container, transportation, and burial costs, but does not include the direct labor costs for removing and packaging these materials.

\subsubsection{Costs for Staff Labor}

The costs for staff labor during preparations for passive safe storage are shown in detail in Table J.5-4 in Appendix J. More than 65\% of the cost for 
TABLE 10.2-1. Summary of the Estimated Costs for the Preparations for Passive Safe Storage

\section{Cost Category}

Disposal of Radioactive Mate-

rials (Radioactive Wastes $(d)$ )

Staff Labor

Energy

Special Tools and Equipment

Miscellaneous Supplies

Specialty Contractors $(e)$

Nuclear Insurance

License Fees

Subtotal

Contingency $(25 \%)$

Total, Preparations for Passive

Safe Storage Costs

Other Possible Costs

Spent Fuel Shipment

Fuel Channel Disposal

Subtota 1

Contingency (25\%)

Total, Other Possible Costs
Estimated Costs

\begin{tabular}{l} 
Percent \\
Total $(c)^{\rho f}$ \\
\hline
\end{tabular}

\begin{tabular}{rr}
1.216 & 7.1 \\
11.254 & 66.1 \\
2.122 & 12.5 \\
& \\
0.351 & 2.1 \\
1.361 & 8.0 \\
0.196 & 1.2 \\
0.500 & 2.9 \\
0.038 & -0.2 \\
\hline 17.038 & 100.0
\end{tabular}

4.260
66.1

12.5

2.1

8.0

.2

2.9

0.2

100.0

21.298

\begin{tabular}{l}
$3.788(\mathrm{f})$ \\
$0.617^{(g)}$ \\
\hline 4.405 \\
1.101 \\
\hline
\end{tabular}

5.506

(a) Costs adjusted to early 1978 .

(b) The number of significant figures shown is for computational completeness and does not imply accuracy to the nearest $\$ 1000$.

(c) Individually rounded to the nearest $0.1 \%$.

(d) Includes both wet solid wastes and dry solid wastes.

(e) Includes temporary radwaste, environmental monitoring services, and security preparations.

(f) If required, shipment by special train would cost an additional estimated $\$ 2.451$ million, maximum.

(g)Deep geologic disposal ( $\$ 1.047$ million) and use of special trains $(\$ 0.456$ million) could add $\$ 1.5$ million to this estimated cost. 
preparations for passive safe storage is associated with staff labor. A total staff labor cost of about $\$ 11.2$ million is estimated for preparing the reference BWR for passive safe storage. Specialty contractor labor is not included in this total.

\subsubsection{Costs for Energy}

The costs for energy during preparations for passive safe storage are presented in Table J.5-5 in Appendix $\mathrm{J}$, together with the estimated usage of both electricity and fuel oil. The usage of both energy forms is estimated based on a detailed analysis of the requirements for the essential systems and services and on the tasks and schedule for preparations for passive safe storage, presented in Table 9.1-1 and Figure 9.2-2 in Chapter 9, respectively.

A total of $76,510 \mathrm{MWh}$ of electricity, costing $\$ 1,147,650$, and $7385 \mathrm{~m}^{3}$ of fuel 011 , costing $\$ 974,820$, is estimated to be used. The total cost for energy is about $\$ 2.1$ million, which is about $13 \%$ of the total cost of preparations for passive safe storage.

\subsubsection{Costs for Special Tools and Equipment}

The estimated costs for the special tools and equipment that are required for preparing the reference BWR for passive safe storage are presented in Table J.5-6 in Appendix J. The estimated total cost for special tools and equipment is approximately $\$ 0.35$ million, which represents approximately $2 \%$ of the total cost for preparations for passive safe storage.

\subsubsection{Costs for Miscellaneous Supplies}

A variety of supplies are used during preparations for passive safe storage. These include expendable glass-fiber and HEPA filters, anticontamination clothing, cleaning and contamination control supplies, expendable hand tools, cutting and welding supplies, decontamination chemicals, and filter/ demineralizer resins. The estimated costs for these items are given in Table J.5-7 in Appendix J. The total estimated cost for miscellaneous supplies is over $\$ 1.3$ million and represents about $8 \%$ of the total preparations for passive safe storage cost. 


\subsubsection{Costs for Specialty Contractors}

The estimated costs for specialty contractors are given in Table J.5-8, Appendix J. As discussed in Section H.3 of Appendix H, these specialty contractors perform temporary radwaste handling and environmental monitoring. The costs for a hauling contractor are not shown in Table J.5-8, but are shown as "transportation costs" in Section J.5.1.1 for disposal of radioactive wastes.

The total cost for specialty contractors, excluding the hauling contractor, is approximately $\$ 195,500$, which is $1.1 \%$ of the total cost for preparations for passive safe storage.

\subsubsection{Costs for Nuclear Insurance}

The costs for nuclear liability insurance during preparations for passive safe storage are estimated for an assumed policy limit of $\$ 125$ million carried through the active decommissioning period. The total estimated cost for nuclear insurance is $\$ 0.5$ million, which represents approximately $3 \%$ of the total cost for preparations for passive safe storage.

The estimated cost for nuclear liability insurance for the reference BWR during the continuing care period is $\$ 2500$ per year.

\subsubsection{Costs for Licensing Fees}

The fees charged for licensing services performed by the NRC are delineated in 10 CFR Part 170. (1) The total cost for licensing fees is estimated to be $\$ 37,850$, which is approximately $0.2 \%$ of the total cost for preparations for passive safe storage.

\subsubsection{0ther Possible Costs}

Other possible costs are discussed in detail in Section 10.1.9; however, only the costs associated with spent fuel shipment and fuel channel disposal are applicable to the total cost analysis during preparations for passive safe storage. The costs for spent fuel shipment are the same as those for immediate dismantlement. The spent fuel shipment cost of $\$ 3,788,000$ (without contingency) does not include either handling costs at the reactor or handling and storage costs at the repository. 
Disposal of the fuel bundle channels might have to be accomplished independently from disposal of the fuel bundles themselves. Burial of the fuel channels in a shallow-land disposal facility is estimated to cost about $\$ 617,000$. Deep geologic disposal of the fuel channels is estimated to add about $\$ 430,000$, and shipment by special train could add about $\$ 456,000$.

\subsubsection{Costs for Continuing Care}

The estimated annual costs for continuing care of the reference BWR while in passive safe storage are developed in Section J.5.2 of Appendix $J$ and are summarized in Table J.5-11. The total annual cost is estimated to be $\$ 75,000$. Staff labor accounts for about $76 \%$ of the total, with allowances for repairs and utilities and services contributing about $17 \%$. Nuclear insurance (4\%), equipment and supplies ( $2 \%$ ), and license fees (1\%) constitute the balance of the annual cost.

\subsection{COSTS FOR ENTOMBMENT}

The estimated costs for entombment of the reference BWR, developed in detail in Section K.3 of Appendix $K$ (Volume 2), are summarized in Table 10.3-1. Costs are shown for the two entombment scenarios considered in this study. The costs are grouped in categories consistent with those used for immediate dismantlement and passive safe storage costs. Entombment scenario 1 (highly activated reactor vessel internals removed) is estimated to cost about $\$ 40.6$ million; entombment scenario 2 (highly activated reactor vessel internals remain in-place) is estimated to cost about $14 \%$ less, or about $\$ 35.0$ million. Annual continuing care costs are estimated at about $\$ 40,000$. Other possible costs are estimated at about $\$ 16.2$ million for scenario 1 and about $\$ 15.6$ million for scenario 2 . The total costs include a $25 \%$ contingency allowance.

\subsubsection{Costs for Disposal of Radioactive Material}

For disposal of radioactive materials, costs are included for disposal of neutron-activated materials, contaminated materials, and radioactive (wet solid and dry solid) wastes. For entombment scenario 1 , these disposal costs contribute $7.4 \%, 5.7 \%$, and $4.5 \%$ of the total entombment costs, respectively; radioactive materials disposal totals about $\$ 5.7$ million ( $17.6 \%$ of the total entombment costs). Entombment scenario 2 involves no offsite disposal of 


\section{TABLE 10.3-1. Summary of Estimated Costs for Entombment}

\begin{tabular}{|c|c|c|c|c|}
\hline \multirow{2}{*}{ Cost Category } & \multicolumn{2}{|c|}{ Entombment Scenario 1} & \multicolumn{2}{|c|}{ Entombment Scenario 2 } \\
\hline & $\begin{array}{l}\text { Estimated costs } \\
(\$ \text { millions })(a, b)\end{array}$ & $\begin{array}{l}\text { Percent } \rho^{f} \\
\text { Total }(c) \\
\end{array}$ & $\begin{array}{l}\text { Estimated Costs } \\
\text { (\$ millions) }(\mathrm{a}, \mathrm{b})\end{array}$ & $\begin{array}{l}\text { Percent } \rho^{f} \\
\text { Total }(c)^{4}\end{array}$ \\
\hline $\begin{array}{l}\text { Disposal of Radioactive Materials } \\
\text { Neutron-Activated Materials } \\
\text { Contaminated Mater }(\text { g) s } \\
\text { Radioactive Wastes } \\
\text { Total Disposal Costs }\end{array}$ & $\begin{array}{l}2.394 \\
1.846 \\
1.469 \\
\end{array}$ & 17.6 & $\begin{array}{l}0 \\
1.992 \\
1.469 \\
\end{array}$ & 12.4 \\
\hline $\begin{array}{l}\text { Staff Labor } \\
\text { Energy } \\
\text { Special Tools and Equipment }\end{array}$ & $\begin{array}{r}18.095 \\
3.775 \\
2.016\end{array}$ & $\begin{array}{r}55.7 \\
11.6 \\
6.2\end{array}$ & $\begin{array}{r}16.999 \\
3.775 \\
0.866\end{array}$ & $\begin{array}{r}60.8 \\
13.5 \\
3.1\end{array}$ \\
\hline $\begin{array}{l}\text { Miscellaneous Supplies } \\
\text { Specialty Contractors }(e) \\
\text { Nuclear Insurance } \\
\text { License Fees }\end{array}$ & $\begin{array}{l}1.859 \\
0.172 \\
0.800 \\
0.039 \\
\end{array}$ & $\begin{array}{l}5.7 \\
0.5 \\
2.5 \\
0.1 \\
\end{array}$ & $\begin{array}{l}1.859 \\
0.172 \\
0.800 \\
0.039 \\
\end{array}$ & $\begin{array}{l}6.6 \\
0.6 \\
2.9 \\
0.1 \\
\end{array}$ \\
\hline Subtotals & 32.465 & 100.0 & 27.971 & 100.0 \\
\hline Contingencies (25\%) & 8.116 & & 6.993 & \\
\hline Totals, Entombment Costs & $\underline{40.581}$ & & $\underline{34.964}$ & \\
\hline Annual Continuing Care Costs & 0.040 & & 0.040 & \\
\hline Other Possible Costs & & & & \\
\hline $\begin{array}{l}\text { Spent Fuel Shipment } \\
\text { Facility Demolition and Site Restoration }(g) \\
\text { Deep Geological Disposal of Highly Activated Materials } \\
\text { Fuel Channel Disposal }\end{array}$ & $\begin{array}{l}3.788(f) \\
8.059(h) \\
0.495(h) \\
0.617\end{array}$ & & $\begin{array}{l}3.788^{(f)} \\
8.059 \\
0 \\
0.617^{(i)}\end{array}$ & \\
\hline Subtotals & 12.959 & & 12.464 & \\
\hline Contingencies (25\%) & 3.240 & & 3.116 & \\
\hline Totals, Other Possible Costs & 16.199 & & 15.580 & \\
\hline
\end{tabular}

(a) Costs adjusted to early 1978.

(D)The number of significant figures shown is for computational completeness and does not imply accuracy to the nearest $\$ 1000$.

(c) Individually rounded to the nearest $0.1 \%$.

(d) Includes both wet solid wastes and dry solid wastes.

(e) Includes temporary radwaste and environmental monitoring services.

(f) If required, shipment by special train costs an estimated additional \$2.451 million, maximum.

(g) Does not include demolition of the Reactor Building or the Guardhouse.

(h) Incremental cost in addition to the cost for shallow-land burial of these materials; the maximum additional cost for shipment by special train is estimated at $\$ 1.254$ million.

(i)Alternate deep geologic disposal costs an estimated $\$ 1.047$ million; shipment by special train to the deep geologic disposal facility increases this cost by an estimated maximum of $\$ 0.456$ million. 
neutron-activated materials. Therefore, scenario-2 disposal costs include just the costs for disposal of contaminated materials and radioactive wastes ( $7.1 \%$ and $5.3 \%$ of the total entombment costs, respectively); total disposal costs are just under $\$ 3.5$ million (about $12.4 \%$ of the total entombment costs). As discussed in Section 10.1 for immediate dismantlement, significant cost savings could be realized by electropolishing stainless steel components to allow release and salvage.

\subsubsection{Costs for Staff Labor}

Staff labor costs include both the management and support staff and the decommissioning workers and cover the planning and preparation period as well as the years of active decommissioning. However, specialty contractor labor is not included in this category. Staff labor is estimated to cost about $\$ 18.1$ million (55.7\% of the tota 1 ) for scenario 1 and about $\$ 17.0$ mi11ion $(60.8 \%$ of the tota 1 ) for scenario 2.

\subsubsection{Costs for Energy}

Energy costs include the costs for electricity and fuel oil consumed during decommissioning. As shown in Table K.3-6 in Appendix K, about 123,500 MWh of electricity and about $14,600 \mathrm{~m}^{3}$ of fuel $0 i 1$ are estimated to be consumed, for a total cost of about $\$ 3.8$ million. This amounts to $11.6 \%$ of the total cost for scenario 1 and $13.5 \%$ of the total for scenario 2 .

\subsubsection{Costs for Special Tools and Equipment}

The costs for special tools and equipment cover development, procurement, and testing of all special tools and equipment required to carry out the entombment project. The total cost for this category is estimated to be just over $\$ 2.0$ million for scenario 1 and about $\$ 870,000$ for scenario 2 ; this represents $6.2 \%$ and $3.1 \%$ of the total entombment costs for scenario 1 and scenario 2 , respectively.

\subsubsection{Costs for Miscellaneous Supplies}

Items such as disposable protective clothing, decontamination chemicals, decontamination agents, rags, mops, plastic bags and sheeting, glass-fiber and HEPA filters, ion exchange resins, and expendable tools are grouped together 
as misgellaneous supplies. The total cost for miscellaneous supplies is estimated to be about $\$ 1.9$ million, which is about $5.7 \%$ of the total cost for scenario 1 or about $6.6 \%$ of the total for scenario 2 .

\subsubsection{Costs for Specialty Contractors}

Specialty contractors provide temporary radwaste processing and environmental monitoring during entombment at an estimated cost of about $\$ 170,000$. This accounts for $0.5 \%$ and $0.6 \%$ of the total cost for scenario 1 and scenario 2 , respectively.

\subsubsection{Costs for Nuclear Insurance and Licensing Fees}

Nuclear insurance and 1 icense fees, estimated to cost about $\$ 800,000$ and about $\$ 39,000$, respectively, make up the balance of the entombment costs, representing $2.6 \%$ to $3.0 \%$ of the total.

\subsubsection{Costs for Continuing Care}

Continuing care, involving surveillance and maintenance of the entombment structure, is estimated to cost about $\$ 40,000$ annually. Thus, a continuing care period of 100 years adds about $\$ 4.0$ million to the cost of decommissioning the reference BWR. In addition, deferred dismantlement of the entombment structure may be required before continuing care can be discontinued and the possessiononly license terminated; this could also add significantly to the overall decommissioning cost.

\subsubsection{Other Possible Costs}

The other possible costs shown at the bottom of Table 10.3-1 are calculated in the same way as those for immediate dismantlement, which are discussed in Section 10.1. The costs for spent fuel shipment and fuel channel disposal are the same as those given for immediate dismantlement. The cost for facility demolition and site restoration after entombment is considerably less than that after immediate dismantlement, because the Reactor Building and the Guardhouse are not demolished. The incremental cost of deep geologic disposal of highly,activated materials versus shallow-land burial is slightly different than that for immediate dismantlement, because of differences in the way these materials are shielded for transport to shallow-land burial. This last cost 
applies only to entombment scenario 1, as all activated materials are assumed to be left in the entombment structure for scenario 2.

\subsection{COSTS FOR DEFERRED DISMANTLEMENT}

The estimated costs for deferred dismantlement of the reference BWR at various times after shutdown are given in Table 10.4-1. Details of these cost estimates are given in Section $\mathrm{J} .7$ of Appendix $J$ (Volume 2). It is assumed that the management and support staff is the same for deferred dismantlement as it is for immediate dismantlement. However, fewer decommissioning workers are required for deferred dismantlement than are required for immediate dismantlement, since the radiation dose rates are lower when dismantlement is deferred.

TABLE 10.4-1. Estimated Deferred Dismantlement Costs $(a)$

\begin{tabular}{|c|c|}
\hline & Dismantlement Costs (\$ millions) ${ }^{(b)}$ \\
\hline & $\begin{array}{l}\text { Dismantlement Deferred } \\
10 \text { and } 30 \text { Years } 50 \text { Years } 100 \text { Ye }\end{array}$ \\
\hline
\end{tabular}

Disposal of Radioactive Materials

Neutron-Activated Materiais

2.300

2.300

2.300

Contaminated Materials

4.909

0.043

0.043

Radioactive Wastes

0.255

0.204

0.140

Staff Labor

16.545

14.210

14.210

Energy

1.479

1.479

1.479

Special Tools and Equipment

1.728

1.728

1.728

Miscellaneous Supplies

0.590

0.590

0.590

Specialty Contractors

0.168

0.168

0.168

Nuclear Insurance

0.400

0.400

0.400

License Fees

0.020

0.020

0.020

Subtotal

28.394

21.142

21.078

7.099

5.286

5.270

Totals

35.493

26.428

26.348

(a) From Table J.7-2 in Appendix J. (b) In constant 1978 dollars. 
The total decommissioning cost for passive safe storage combined with deferred dismantlement after 10, 30, 50, and 100 years is given in Table 10.4-2. The total decommissioning cost is the sum of the costs for preparations for passive safe storage, continuing care, and dismantlement. In constant dollars, the cost for decommissioning the reference BWR by passive safe storage followed by deferred dismantlement is more expensive than the $\$ 43.6$ million cost for immediate dismantlement.

TABLE 10.4-2. Total Decommissioning Costs for Passive Safe Storage with Deferred Dismantlement

Dismantlement Deferred (Years)

\begin{tabular}{cccc}
\multicolumn{4}{c}{ Decommissioning Costs $(\$ \text { millions })^{(a, b)}$} \\
$\begin{array}{cccc}\text { Preparations for } \\
\text { Passive Safe Storage }\end{array}$ & $\begin{array}{c}\text { Continuing } \\
\text { Care }(c)\end{array}$ & $\begin{array}{c}\text { Deferred } \\
\text { Dismantlement }\end{array}$ & Total \\
\cline { 1 - 2 } 21.3 & 0.6 & 35.5 & 57.4 \\
21.3 & 2.0 & 35.5 & 58.8 \\
21.3 & 3.4 & 26.4 & 51.1 \\
21.3 & 6.9 & 26.3 & 54.5
\end{tabular}

(a) Includes $25 \%$ contingency.

(b) In constant 1978 dollars.

(c) The continuing care period extends from the time of completion of the preparations for safe storage, 2 years, until the start of deferred dismantlement. 


\section{REFERENCES}

1. U.S. Code of Federal Regulations, Title 10, Part 170, "Fees for Facilities and Materials Licenses and Other Regulatory Services Under the Atomic Energy Act of 1954, As Amended," Superintendent of Documents, GP0, Washington, DC 20555, 1979. 


\section{DECOMMISSIONING SAFETY}

Occupational, public, and transportation safety impacts from decommissioning the reference BWR nuclear power station are summarized in this chapter. Decommissioning safety impacts include: 1 ) the radiation doses to and industrial accidents involving decommissioning workers during performance of active decommissioning, 2) radiation doses to the public from routine or accidental atmospheric releases of radioactivity during active decommissioning, and 3 ) the radiation doses to the transportation workers and the public during shipment of radioactive materials from the site. A conservative approach, using parameters that tend to maximize the consequences, is used to evaluate the safety impacts of each decommissioning task. The evaluation uses current analysis data and methodology.

The evaluation of decommissioning safety is divided into three parts: occupational safety, public safety, and transportation safety. Radiation doses to and industrial accidents involving decommissioning workers are estimated using information about the expected radiation dose rates discussed in Chapter 7 and the manpower requirements presented in Appendices I, J, and $\mathrm{K}$ of Volume 2 for the three modes of decommissioning the reference BWR. Radiation doses to the public during decommissioning are determined using the routine and accidental atmospheric release scenarios presented in Appendix $\mathrm{N}$ of Volume 2 and the radiation dose methodology presented in Appendix $F$ of Volume 2. Radiation doses to transportation workers and to the public along the transport route are based on the radioactive material shipment requirements of each decommissioning mode and on the permissible radiation exposure rates for shipments of radioactive material.

A detailed probabilistic analysis of postulated accident scenarios during decommissioning is not within the scope of this study. However, selected accidents are considered that can affect both decommissioning workers and the public during decommissioning and transportation tasks. 
The estimated total occupational radiation doses are: 1845 man-rem for immediate dismantlement, 375 man-rem for preparations for passive safe storage, 1684 man-rem for entombment scenario 1, and 1573 man-rem for entombment scenario 2. Radiation doses for deferred dismantlement are based on those for immediate dismantlement, corrected for ${ }^{60}$ Co decay during the safe storage period. Values range from 495 man-rem after 10 years to less than 1 man-rem after 100 years. The occupational doses are corrected for radioactive decay assuming that ${ }^{60}$ Co controls the decay of the external radiation dose rate, using the time after shutdown at which each task is half completed (timewise) and the decay half-life of ${ }^{60} \mathrm{Co}$.

Public radiation doses are calculated for both the maximum-exposed individual and the population residing within $80 \mathrm{~km}$ of the site using the calculated atmospheric releases. For the maximum-exposed individual, the fifty-year committed radiation dose equivalents to the lung (in rem) from routine releases during the decommissioning modes are: $4.1 \times 10^{-5}$ for immediate dismantlement, $3.1 \times 10^{-6}$ for preparations for passive safe storage, and $3.8 \times 10^{-5}$ for entombment scenario 1. Entombment scenario 2, with fewer operations than scenario 1, is not analyzed. For the population, similar doses (in man-rem) are: $5 \times 10^{-2}, 3 \times 10^{-4}$, and $4 \times 10^{-2}$ for the three decommissioning modes, respectively.

The postulated accident that results in the largest release of radioactivity is an explosion of liquified propane gas (LPG) during contaminated concrete rubble removal. LPG is assumed to be the fuel for the front-end loader used to gather the rubble for packaging. The fifty-year committed radiation dose equivalent to the lung of the maximum-exposed individual from this accident is calculated to be $1.5 \times 10^{-4} \mathrm{rem}$.

These public radiation doses are comparable with or less than those calculated for similar tasks at an operating BWR power station. This is because of 1) the reduced inventories of radionuclides after the reactor fuel has been shipped and after chemical decontamination, 2) the carefully designed procedures that minimize atmospheric release, 3 ) the use of existing process and HVAC systems to ensure proper air flows in isolated work areas. 
Transportation of radioactive materials results in external radiation doses to the transportation workers and to the public along the transportation route. For rail shipment of spent reactor fuel, the external dose to the rail transportation workers is calculated to be 5.4 man-rem and the external dose to the population is calculated to be 0.46 man-rem. The shipment of spent reactor fuel is assumed to result in the same radiation doses for all three decommissioning modes considered. External radiation doses (in man-rem) to truck transportation workers during radioactive waste shipments are calculated to be: 110 for immediate dismantlement, 22 for preparations for passive safe storage, 69 for entombment scenario 1, and 51 for entombment scenario 2. For the population, corresponding doses (in man-rem) are: 10, 2.2, 6.7, and 4.9. For deferred dismantlement, the immediate dismantlement doses are reduced in proportion to the decay of ${ }^{60}$ Co during the safe storage period.

\subsection{TECHNICAL APPROACHES}

The safety evaluation is divided into two areas of interest: radiological safety and nonradiological safety. Radiological safety is evaluated using a three-part technical approach. First, a description of the reference facility is developed (see Chapter 7). Second, the radionuclide inventories and external dose rates within the facility are characterized and quantified (also see Chapter 7). Finally, reference decommissioning tasks are defined for each mode to permit calculation of radiation exposures (discussed in Appendices I, $J, K$, and $N)$. The nonradiological safety evaluation is based on industrial and transportation accidents that result in injuries or fatalities. The technical approach is divided into two parts. First, the total labor requirements for each decommissioning mode are analyzed and divided into categories of effort (discussed in Appendices I, J, and $\mathrm{K}$ ); second, injuries and fatalities are calculated based on statistical information from the literature on accident frequencies for the different categories of effort.

Key assumptions are made during the safety evaluation to coordinate the parts of each of the technical approaches. Some of the major assumptions are: 
1. The quantities, mixtures of radionuclides, and external dose rates are typical of those found at an operating BWR, as discussed in Chapter 7. The reference radionuclide mixtures at the time of final shutdown of the reference BWR are mixtures that characterize: stainless steel activation products, carbon steel activation products, reinforced concrete activation products, internal surface contamination, and structural surface external contamination.

2. The plant equipment areas are kept relatively free of radioactive contamination during the operating lifetime to permit operational maintenance. As a result, expected radioactive contamination levels are generally modest and are reasonably consistent with the quality of operation expected in modern commercial nuclear power plants.

3. Accidents that occur during plant operation are relatively minor with respect to radioactive contamination of normally clean surfaces. Any major contamination episodes are cleaned up immediately following the event.

4. Radiation protection techniques applied conform to the principle of keeping occupational radiation dose as low as reasonably achievable (ALARA).

5. All radioactive wastes shipped offsite are shipped in accordance with Department of Transportation regulations. Spent reactor fuel is shipped $2400 \mathrm{~km}$ by rail to a repository and radioactive wastes are shipped $800 \mathrm{~km}$ by truck to a shallow-land burial ground.

6. The largest potential radiological consequence of a given decommissioning task is associated with performing that operation in the area with the largest inventory of radionuclides.

7. The maximum release from a specific decommissioning task applies to that task whenever it is used in the facility. In performing the dose calculations for releases of radionuclides from routine tasks, the estimated total releases for the entire decommissioning period are released at a uniform rate during a 1-year period. 
8. All atmospheric releases contain the radionuclide mixtures that are present at plant shutdown, with no credit taken for radioactive decay. (Radionuclide releases during deferred dismantlement after a period of continuing care are not calculated in this analysis.)

9. The atmospheric release of radionuclides is the only source of radiation to the public from routine decommissioning. (All liquid releases are assumed to be within the limits established for an operating BWR, and they are not further analyzed in this study.)

10. A contamination control envelope has a transmission factor of $5 \times 10^{-4}$ through the filtered exhaust and a leakage of $10 \%$, which is used as a maximized value to account for routine ruptures or failures of the contamination control envelope.

Other specific assumptions used in calculating the occupational doses are found in Appendices I, J, and K. A complete discussion of the assumptions and methods used for the public and transportation radiation dose calculations is found in Appendix $N$.

\subsection{OCCUPATIONAL SAFETY OF DECOMMISSIONING THE REFERENCE BWR}

Occupational safety for immediate dismantlement, passive safe storage, and entombment is evaluated both for radiation exposure and for nonradiological industrial accidents.

Estimates of occupational radiation doses are based on the postulated radiation dose rates in various areas of the reference BWR and on the estimated staff labor required to complete the decommissioning work. Summaries of the detailed information given in Appendices $I, J$, and $K$ are given in this section. This section also presents estimates of worker injuries and fatalities resulting from decommissioning the reference BWR. These industrial accidents estimates are based on nuclear industry experience.

\subsubsection{Occupational Radiation Dose from Decommissioning Activities}

Summaries of the estimated occupational radiation doses for immediate dismantlement, preparations for passive safe storage, and scenario-1 entombment 
are given in Tables $11.2-7,11.2-2$, and $11.2-3$, respectively. These tables contain listings of the decommissioning tasks and the associated estimated total man-hours of exposure to radiation and estimated total external radiation doses. Entombment scenario 2, which is a lesser effort than scenario 1, is not analyzed in detail. An estimate of the radiation dose for scenario 2 is obtained by subtracting the doses for those activities not performed from the total dose for scenario 1.

The radiation doses to decommissioning workers are calculated as the product of the estimated radiation zone manpower requirements and the radiation dose rates postulated for each specific decommissioning task. The occupational dose estimates are based on the following basic assumptions: 1) personnel exposure to radiation while accomplishing a task is minimized by using temporary shielding and remote handling techniques and by staying out of radiation fields when not actively participating in the work, 2) the chemical decontamination campaign is reasonably successful, reducing all radiation dose rates from piping and equipment by at least a factor of 10,3) careful, prompt accounting of radiation doses is maintained to rapidly identify jobs that are causing excessive dose accumulations so that corrective action can be taken, and 4$){ }^{60} \mathrm{Co}$ is the dominant radioactive species.

The radioactive materials that are the source of the radiation dose rate decay throughout the decommissioning period. Therefore, the estimated total occupational radiation dose for each task is corrected for radioactive decay between the time of final reactor shutdown and the time at which the task is one-half completed, using the half-life of ${ }^{60} \mathrm{Co}$.

For immediate dismantlement of the reference BWR, the estimated total occupational radiation dose is 1845 man-rem. Dismantlement activities in the Reactor Building/ Primary Containment are the main contributors to this total. The four general dismantlement activities for the reference BWR that result in the highest doses, in descending order of dose contribution, are: 1) removal of the piping and equipment from the Reactor Building/Primary containment, 2) removal of the piping and equipment from the Radwaste and Control Building, 3) removal of the piping and equipment from the Turbine Generator Building, and 4) removal and shipment of the reactor vessel and internals. 
TABLE 11.2-1. Summary of Estimated Occupational Radiation Doses for Immediate Dismantlement(a)

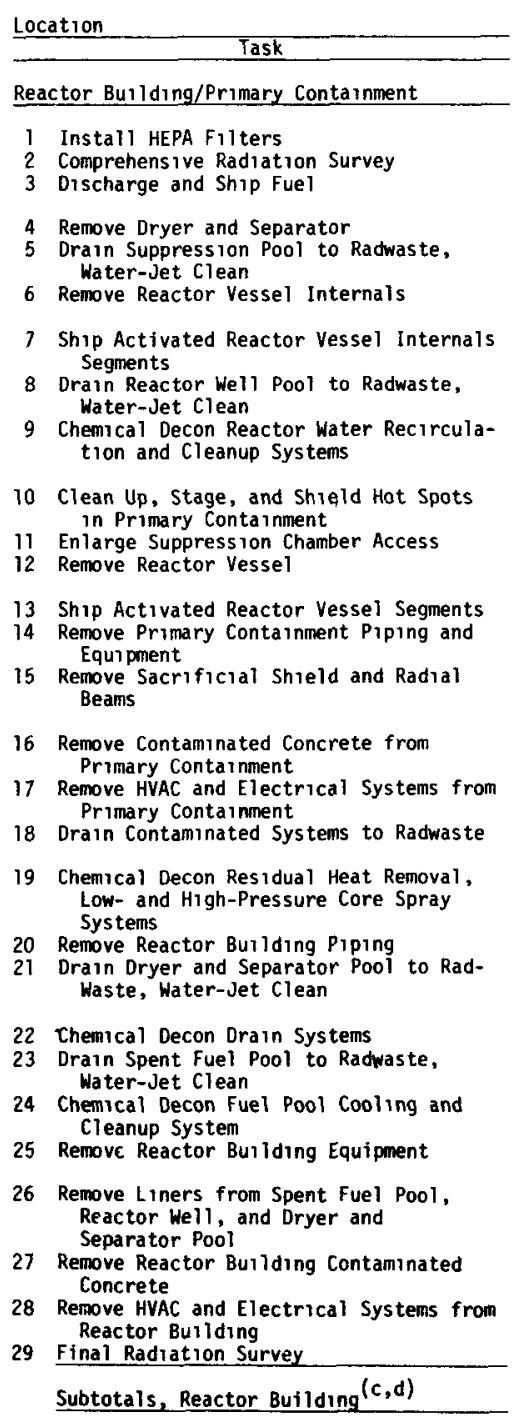

\begin{tabular}{|c|c|c|c|}
\hline \multicolumn{4}{|c|}{ Task Totals } \\
\hline $\begin{array}{l}\text { Exposure } \\
\text { (man-hr) }\end{array}$ & $\begin{array}{c}\text { Dose } \\
\text { (man-rem) }\end{array}$ & $\begin{array}{l}\text { Decay (b) } \\
\text { Factor }\end{array}$ & $\begin{array}{l}\text { Corrected } \\
\text { Dose } \\
(\operatorname{man}-r e m) \\
\text { (c) }\end{array}$ \\
\hline
\end{tabular}

\begin{tabular}{|c|c|c|c|}
\hline $\begin{array}{r}3382 \\
100 \\
9961\end{array}$ & $\begin{array}{rr}3 & 382 \\
0 & 500 \\
89 & 649\end{array}$ & $\begin{array}{ll}1 & 000 \\
0 & 995 \\
0 & 904\end{array}$ & $\begin{array}{rl}3 & 382 \\
0 & 498 \\
81 & 043\end{array}$ \\
\hline 1627 & 8135 & 0989 & 8046 \\
\hline $\begin{array}{r}403 \\
6 \quad 123\end{array}$ & $\begin{array}{r}2391 \\
30616\end{array}$ & $\begin{array}{l}0957 \\
0 \quad 944\end{array}$ & $\begin{array}{r}2288 \\
28902\end{array}$ \\
\hline 15547 & 77735 & 0921 & 71594 \\
\hline 68 & 0340 & 0906 & 0308 \\
\hline 620 & 7939 & 0896 & 7113 \\
\hline $\begin{array}{r}900 \\
525 \\
3 \quad 338\end{array}$ & $\begin{array}{r}9000 \\
2625 \\
16690\end{array}$ & $\begin{array}{ll}0 & 906 \\
0 & 898 \\
0 & 874\end{array}$ & $\begin{array}{rr}8154 \\
2357 \\
14587\end{array}$ \\
\hline 4326 & 21630 & 0835 & 18061 \\
\hline 11507 & $230 \quad 140$ & 0829 & 193087 \\
\hline 9130 & 102060 & 0781 & 79709 \\
\hline 4092 & 21405 & 0768 & 16439 \\
\hline $\begin{array}{r}545 \\
18\end{array}$ & $\begin{array}{ll}2 & 727 \\
0 & 270\end{array}$ & $\begin{array}{ll}0 & 732 \\
0 & 933\end{array}$ & $\begin{array}{ll}1 & 996 \\
0 & 252\end{array}$ \\
\hline $\begin{array}{l}409 \\
15 \quad 221\end{array}$ & $\begin{array}{r}9403 \\
304 \quad 470\end{array}$ & $\begin{array}{ll}0 & 989 \\
0 & 896\end{array}$ & $\begin{array}{r}9300 \\
272805\end{array}$ \\
\hline 122 & 0610 & 0848 & 0517 \\
\hline 539 & 0539 & 0841 & 0453 \\
\hline 136 & 0680 & 0803 & 0546 \\
\hline $\begin{array}{r}74 \\
19 \quad 225\end{array}$ & $\begin{array}{rl}0 & 450 \\
38 & 442\end{array}$ & $\begin{array}{ll}0 & 810 \\
0 & 849\end{array}$ & $\begin{array}{rr}0 & 364 \\
32 & 637\end{array}$ \\
\hline 2248 & 11240 & 0764 & 8587 \\
\hline 8444 & 25837 & 0746 & 19274 \\
\hline $\begin{array}{r}2462 \\
100 \\
\end{array}$ & $\begin{array}{rr}12 & 310 \\
0 \quad 100 \\
\end{array}$ & $\begin{array}{ll}0 & 724 \\
0 & 716\end{array}$ & $\begin{array}{ll}8 & 912 \\
0 & 072 \\
\end{array}$ \\
\hline 19 & 31 & & 891 \\
\hline
\end{tabular}


TABLE 11.2-1. Summary of Estimated Occupational Radiation Doses for Immediate Dismantlement(a) (contd)

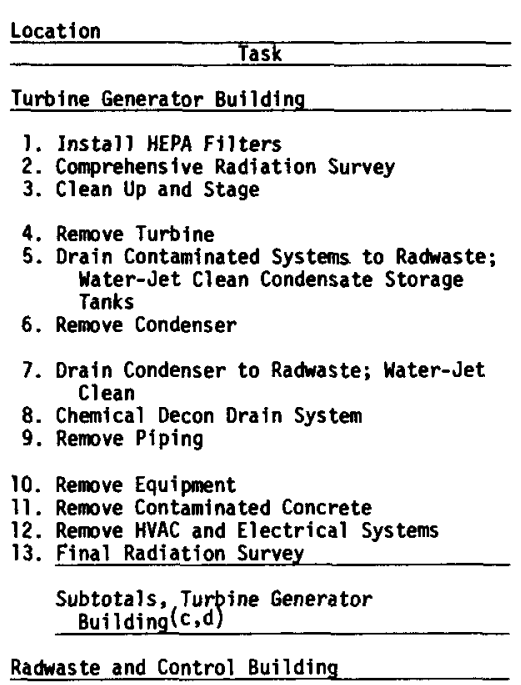

1. Comprehensive Radiation Survey

2. General Cleanup

3. Chemical Decon Orain Sys tems

4. Chemical Decon Equipment; Water-Jet

5. Remove Piping

6. Insta11 Temporary Radwaste System

7. Remove Ëüuipment

Remove Contaminated Concrete

9. Remove Miscellaneous Steel Structures

10. Remove HVAC and Electrical Systems

11. Final Radiation Survey Subtotals, Ragyaste and Control
Building $(\mathrm{c}, \mathrm{d})$

Ancillaries

1. Operate Racwaste Systems

2. Routine Radiation Surveys

3. Package Dry Soljd Wastes

4. Miscellaneous (e)

Subtotals, Ancillaries (c,d)

Totals (from all locations) ${ }^{(c)}$

\begin{tabular}{lcll}
\multicolumn{4}{c}{ Task Totals } \\
\hline $\begin{array}{c}\text { Exposure } \\
\text { (man-hr) }\end{array}$ & $\begin{array}{c}\text { Dose } \\
\text { (man-rem) }\end{array}$ & $\begin{array}{l}\text { Decay } \\
\text { Factor (b) }\end{array}$ & $\begin{array}{c}\text { Corrected } \\
\text { Dose } \\
\text { (man-rem) }\end{array}$ \\
(c)
\end{tabular}

$9295 \quad 9.295 \quad 1.000$

$\begin{array}{llll}100 & 0.200 & 0.995 & 0.199\end{array}$

$\begin{array}{llll}870 & 0.870 & 0.984 & 0.856\end{array}$

$\begin{array}{llll}4632 & 8.857 & 0.952 & 8.432\end{array}$

$\begin{array}{rrrr}64 & 0.064 & 0.921 & 0.059\end{array}$

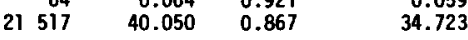

$\begin{array}{rrrr}12 & 0.012 & 0.872 & 0.010 \\ 381 & 0.381 & 0.855 & 0.326\end{array}$

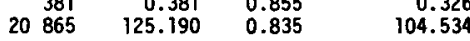

$\begin{array}{llll}8267 & 41.335 & 0.781 & 32.283\end{array}$

$\begin{array}{llll}2543 & 2.543 & 0.762 & 1.938\end{array}$

$\begin{array}{llll}50 & 0.050 & 0.744 & 0.425\end{array}$

$\underline{69167} \quad \underline{229} \quad \underline{193}$

$80 \quad 0.800,0.995 \quad 0.796$

$\begin{array}{lllr}210 & 2.850 & 0.828 & 2.360 \\ 544 & 0.544 & 0.810 & 0.441\end{array}$

$\begin{array}{rrrr}450 & 22.615 & 0.797 & 18.024 \\ 6222 & 330.774 & 0.752 & 248.742\end{array}$

$\begin{array}{rrrr}44 & 0.088 & 0.786 & 0.786\end{array}$

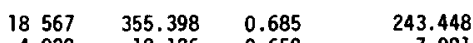

$\begin{array}{llll}4020 & 12.126 & 0.659 & 7.991\end{array}$

$\begin{array}{llll}679 & 1.358 & 0.648 & 0.880\end{array}$

\begin{tabular}{rrrr}
2689 & 10.629 & 0.642 & 6.824 \\
80 & 0.080 & 0.635 & 0.051 \\
\hline
\end{tabular}

$66985 \quad \underline{737} \quad \underline{530}$

\begin{tabular}{|c|c|c|c|}
\hline $\begin{array}{l}446 \\
1950 \\
2200 \\
-- \\
\end{array}$ & $\begin{array}{r}23.525 \\
7.950 \\
48.562 \\
-- \\
\end{array}$ & $\begin{array}{c}0.886 \\
0.799 \\
0.799 \\
\ldots-\end{array}$ & $\begin{array}{r}20.843 \\
6.352 \\
38.801 \\
165 \\
\end{array}$ \\
\hline 4616 & 80 & & 231 \\
\hline
\end{tabular}

(a) Taken from Table I.4-1 in Appendix $I$ in Volume 2.

(b) Based on the half-life of ${ }^{60} \mathrm{Co}$; calculated at the midpoint of the task timelines shown in Figure 9. $9-1$ in Chapter 9.

(c) The number of significant figures shown is for computational convenience and does not imply precision of that degree.

(d) Dose totals are rounded to the nearest whole number.

(e) Consists of an allowance of up to $]$ rem per year for selected management and support

staff whose radiation doses are not specifically estimated together with an allowance

of $5 \%$ of the total explicitly estimated task radiation dose, to account for any omissions of $5 \%$ of the total explicitly estimat 


\section{TABLE 11.2-2. Summary of Estimated Occupational Radiation Doses for Preparations for Passive Safe Storage(a)}

\begin{tabular}{|c|c|c|c|c|}
\hline \multirow[b]{2}{*}{ Location } & \multicolumn{4}{|c|}{ Task Totals } \\
\hline & $\begin{array}{l}\text { Exposure } \\
\text { (man-hr) }\end{array}$ & $\begin{array}{c}\text { Dose } \\
\text { (man-rem) } \\
\end{array}$ & $\begin{array}{l}\text { Decay }(b) \\
\text { Factor }\end{array}$ & $\begin{array}{l}\text { Corrected } \\
\text { Dose } \\
\text { (man-rem) }\end{array}$ \\
\hline \multicolumn{5}{|l|}{ Reactor Bullding/Primary Conta inment } \\
\hline $\begin{array}{l}\text { 1. Install HEPA Filters } \\
\text { 2. Comprehensive Radiation Survey } \\
\text { 3. Discharge and Ship Fuel } \\
\text { 4. Drain Suppression Pool to Radwaste; } \\
\text { Water-Jet Clean }\end{array}$ & $\begin{array}{l}3382 \\
100 \\
9961\end{array}$ & $\begin{array}{r}3.382 \\
0.500 \\
89.649\end{array}$ & $\begin{array}{l}1.000 \\
0.995 \\
0.904 \\
0.957\end{array}$ & $\begin{array}{r}3.382 \\
0.498 \\
81.043 \\
2.288\end{array}$ \\
\hline $\begin{array}{l}\text { 5. Drain Reactor Well Pool to Radwaste; } \\
\text { Water-Jet Clean } \\
\text { 6. Chemical Decon Reactor Water Recircula- } \\
\text { tion and Cleanup Systems } \\
\text { 7. Clean Up, Stage and Shield Hot Spots }\end{array}$ & $\begin{array}{l}620 \\
625\end{array}$ & $\begin{array}{l}0.340 \\
7.939 \\
6.250\end{array}$ & $\begin{array}{l}0.921 \\
0.913\end{array}$ & $\begin{array}{l}0.317 \\
7.312 \\
5706\end{array}$ \\
\hline $\begin{array}{l}\text { 8. Orain Contaminated Systems to Radwaste } \\
\text { 9. Chemical Decon Residual Heat Removal, } \\
\text { Low- and High-Pressure Core Spray } \\
\text { Systems } \\
\text { 10. Drain Dryer and Separator Pool to Rad- } \\
\text { waste; Water-Jet Clean }\end{array}$ & 409 & 9.403 & 0.893 & 8.397 \\
\hline $\begin{array}{l}\text { 11. Chemical Decon Drain Systems } \\
\text { 12. Drain Spent Fuel Pool to Radwaste; } \\
\text { Water-Jet Clean } \\
\text { 13. Chemlcal Decon Fuel Pool Cooling and } \\
\text { Cleanup System }\end{array}$ & 136 & 0.539 & 0.802 & 0.545 \\
\hline $\begin{array}{l}\text { 14. Cover and Seal Spent Fuel Pool and Dryer } \\
\text { and Separator Storage Pool } \\
\text { 15. Seal Equipment and Personnel Hatches } \\
\text { Into Primary Containment } \\
\text { 16. Decontaminate HVAC Electrical Miscel- } \\
\text { laneous Steel Structures and Equipment } \\
\text { and Concrete; Apply Protective Paint }\end{array}$ & 1798 & 4.620 & 0.785 & 3.627 \\
\hline $\begin{array}{l}\text { 17. Isolate and Seal Equipment, Piping, } \\
\text { Rooms, Stack HVAC Ducts, Rail Tunnel } \\
\text { and Steam Tunnel } \\
\text { 18. Seal Drywell Top Head and Unneeded } \\
\text { Reactor Building Doors } \\
\text { 19. Install HEPA-Filtered Vents }\end{array}$ & $\begin{array}{l}2666 \\
495 \\
112\end{array}$ & $\begin{array}{l}33.325 \\
0.990 \\
0.784\end{array}$ & $\begin{array}{l}0.751 \\
0.741 \\
0.741\end{array}$ & $\begin{array}{l}0.734 \\
0.581\end{array}$ \\
\hline $\begin{array}{l}\text { 20. Deactivate Unnecessary Utilities } \\
\text { 21. Install Intrusion, Radiation Monitoring } \\
\text { and Fire Alarm Systems } \\
\text { 22. Final Radiàtion Survey }\end{array}$ & $\begin{array}{l}600 \\
100 \\
\end{array}$ & $\begin{array}{l}1.800 \\
0.400 \\
\end{array}$ & $\begin{array}{l}0.730 \\
0.732\end{array}$ & $\begin{array}{l}1.314 \\
0.239 \\
\end{array}$ \\
\hline Subtotals, Reactor Building $(c, d)$ & $\underline{24 \quad 359}$ & 181 & & 155 \\
\hline
\end{tabular}


TABLE 11.2-2. Summary of Estimated Occupational Radjafion Doses for Preparations for Passive Safe Storage(a) (contd)

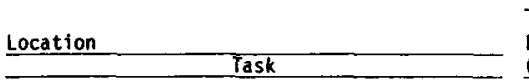

Turbine Generator Builiding

1. Install HEPA Filters

2. Comprehensive Radiation Survey

3. General Cleanup

4. Drain Contaminated Systems to Radwaste; Water-Jet Clean Condensate Storage Tanks

5. Drain Condenser to Radwaste; Water-Jet Clean

6. Chemical Decon Drain Systems

7. Decontaminate HVAC Electrical Miscellaneous Steel Structures and Equipment and Concrete; Apply Protective Paint

8. Isolate and Seal Equipment, Piping. Rooms Stack and HVAC Ducts

9. Install HEPA-Filtered Vents

10. Deactivate Unnecessary Utilities

11. Install Intrusion, Radiation Monitoring and Fire Alarm Sys tems

12. Final Radiation Survey

Subtotals, Turbine Generator Building (c,d)

Radwaste and Control Building

1. Comprehensive Radiation Survey

2. General Cleanup

3. Decontaminate Equipment External Surfaces; Apply Protective Paint

4. Decontaminate Electrical Equipment, Miscellaneous Steel Structures, and
HVAC; Apply Protective Paint

5. Decontaminate Concrete; Apply Protective Paint

6. Chemical Decon Drain Systerns

7. Install Temporary Radwaste System

8. Chentcal Decon Equipment

9. Install HEPA-Filtered Vents 10. Deactivate Unnecessary Equipment and
Utilities

11. Isolate and Seal Equipment and Areas

12. Install Instrusion, Radiation Monitoring

and Fire Alarm Systems

3. Final Radiation Survey

Subtotals, Ragwaste and Contro

Building (c,d)

Site and Support Facilities

1. Final Radiation Survey

Subtotals, Site and Support

Facilities $(c, d)$

Ancilliaries

1. Operate Radwaste Systens

2. Routine Radiation Surveys

3. Package Dry Solid Wastes

3. Package Dry Sqlid

Subtotals, Ancillaries (c,d)

Totals (from all locations) (c)

\begin{tabular}{|c|c|c|c|}
\hline n- & $\begin{array}{c}\text { Dose } \\
\text { (man-rem) }\end{array}$ & $\begin{array}{l}\text { Decay } \\
\text { Factor }(b)\end{array}$ & $\begin{array}{l}\text { Corrected } \\
\text { Dose } \\
\text { (man-rem) } \\
(\mathrm{c})\end{array}$ \\
\hline
\end{tabular}

$\begin{array}{ll}100 & 0.200 \\ 870 & 0.870\end{array}$

1.000

0.896
0.886

9.295

$64 \quad 0.064$

0.867

0.771

600

0.600

0.838

0.056

381

0.381

0.822

0.503

1159

3.101

0.813

2.521

138

4.148

4.148
0.034

0.791

0.791
0.783

0.783
0.780

3.277
0.027
0.371

0.371

$600 \quad 0.900$

\begin{tabular}{ll}
600 & 0.900 \\
100 & 0.200 \\
\hline
\end{tabular}

0.772
0.766

0.695

$15060 \quad 20$

18

$\begin{array}{rrrr}80 & 0.080 & 0.862 & 0.069 \\ 210 & 2.850 & 0.855 & 2.437 \\ 690 & 27.480 & 0.848 & 23.303\end{array}$

$1455 \quad 1.455$

0.836

1.216

847

10.254

0.827

8.480

0.430

440.088

$\begin{array}{lll}1 & 379 & 20.575 \\ 3 & 708 & 29.66\end{array}$

0.780
0.780

0.069

16.048

22.396

$\begin{array}{llll}858 & 0.858 & 0.766 & 0.657\end{array}$

$\begin{array}{rr}858 & 0.858 \\ 3708 & 29.664\end{array}$

0.755

22.396

0.735

0.610

$\begin{array}{ll}510 & 0.830 \\ 176 & 0.176\end{array}$

0.726

$\begin{array}{r}0.610 \\ 0.128 \\ \hline\end{array}$

99

$14209 \quad 125$.

0.726

$\underline{0.007}$

$\underline{0}$

21120

0.877

0.860
0.858

20.631

\begin{tabular}{rr}
466 & 23.525 \\
996 & 4.084 \\
767 & 15.490 \\
\hline
\end{tabular}

\begin{tabular}{ll}
767 & 15.490 \\
-- & -- \\
\hline
\end{tabular}

2229

57969

369
3.512
13.290

\begin{tabular}{l}
13.290 \\
\hline
\end{tabular}

103

375

(a) Taken from Table J.6-1 in Appendix $\mathrm{J}$ in Volume 2

(b) Based on the half-life of $6 \mathrm{O}_{\mathrm{CO}}$; calculated at the midpoint of the task timelines shown in

(c) The number of significant figures is for computational convenicence and does not The nuber of significant figures
inecision of that degree.

(d) Dose totals are rounded to the nearest nole number.

(e)Consists of an allowance of up to 1 rem per year for selected management and support staff whose radiation doses are not specifically estimated, together with an allowance of $5 \%$ of the total explicitly estimated task radiation dose, to account for any omissions and uncertainties in the analyses. 


\section{TABLE 11.2-3. Summary of Estimated Occupational Radiation Doses for}

Scenario-1 Entombment(a)

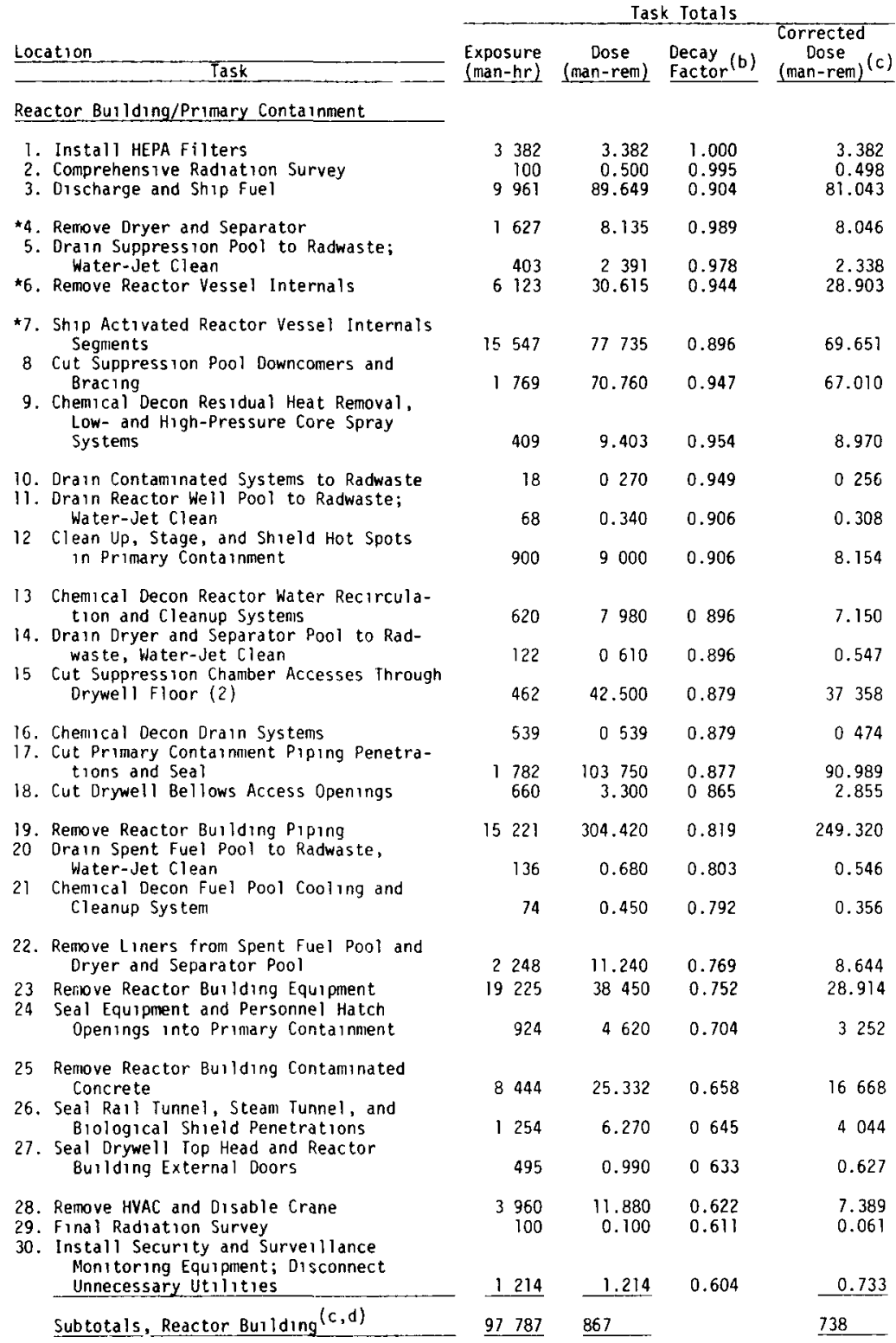

* These tasks deleted for entombment scenario 2. 


\section{TABLE 11.2-3. Summary of Estimated Occupational Radiation Doses for Scenario-1 Entombment(a) (contd)}

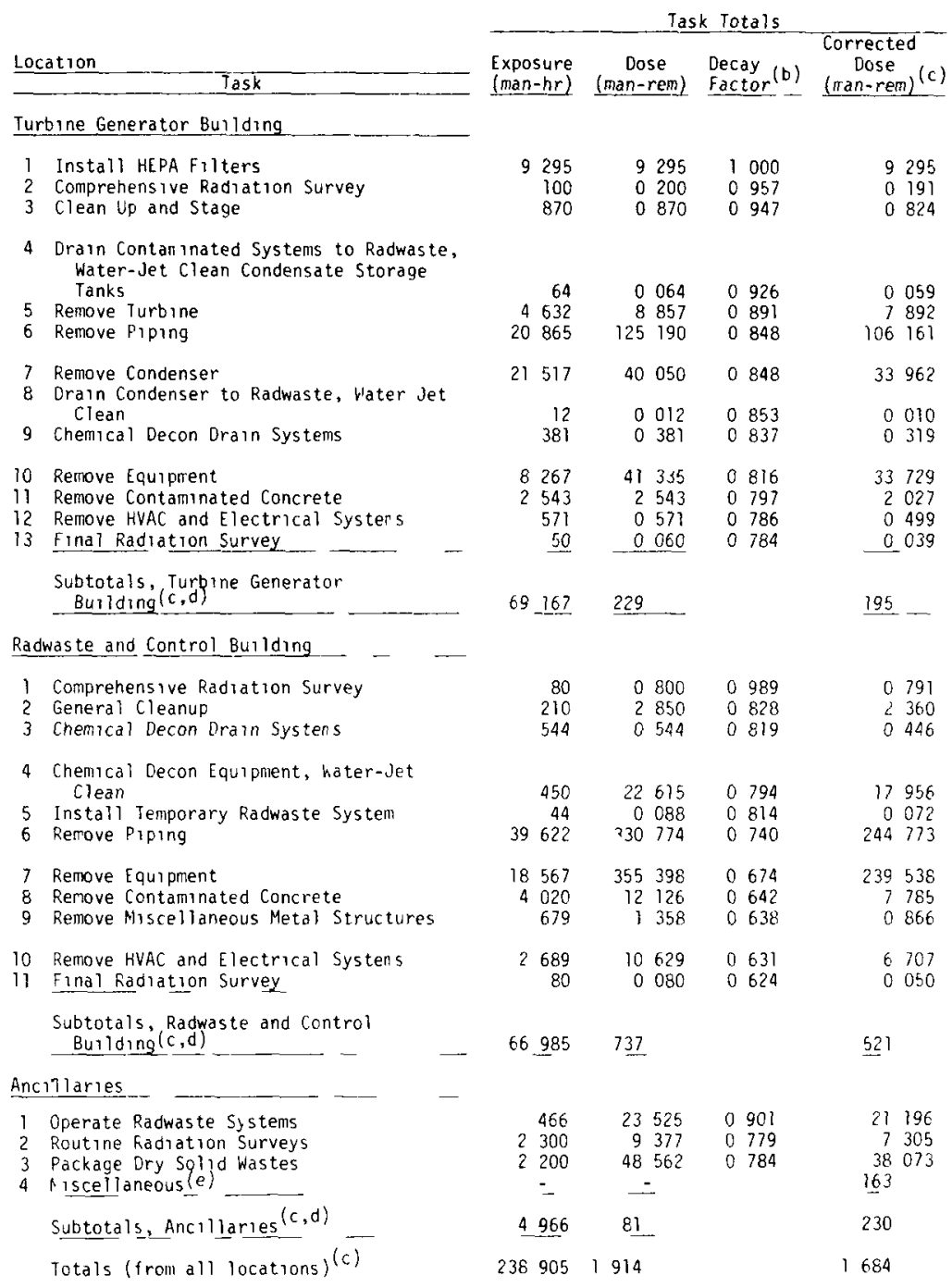

(a) Taken from Table $k 41$ in Appendix $K$ in Volunie 2

(b) Based on the half life of $60 \mathrm{CO}$ calculated at the midpoint of the task timelines shown in Frgure 93 in Chapter 9

(c) The number of significant figures shown is for computational convenience and does not iriply accuracy to the nearest $m 1$ llirem

(d) Dose totals are rounded to the nearest nan-rem

(e) Consists of an allowance of up to 1 rem per year for sclected management and suppor $t$ staff whose radiation doses are not specifically estimated, together with an allowance of 5 of the total explicitly estriated task radiation dose, to account for any on issions and uncertainties in the analyses 
The estimated total occupational radiation dose for preparations for passive safe storage of the reference BWR is 375 man-rem.

The estimated total occupational radiation dose for scenario- 1 entombment of the reference BWR is 1684 man-rem and for scenario-2 entombment, 1573 man-rem.

The average quarterly radiation doses to decommissioning workers for immediate dismantlement, preparations for passive safe storage, and entombment are estimated in Table 11.2-4. These quarterly average doses are based on the accumulated occupational doses, after correction for radioactive decay.

TABLE 11.2-4. Estimated Quarterly Occupational Radiation Doses from the Various Decommissioning Alternatives

\begin{tabular}{|c|c|c|c|c|c|}
\hline \multirow[b]{2}{*}{ Decommissioning Mode } & \multirow{2}{*}{$\begin{array}{l}\text { Total Dose } \\
\text { for Mode } \\
\text { (man-rem) }\end{array}$} & \multicolumn{2}{|c|}{ Hands-on Workers $(a)$} & \multicolumn{2}{|c|}{ All Decommissioning Workers } \\
\hline & & $\begin{array}{l}\text { Total Work Time } \\
\text { (man-years) }\end{array}$ & $\begin{array}{l}\text { Average Dose } \\
\text { (rem/quarter) }\end{array}$ & $\begin{array}{l}\text { Total Work Time } \\
\text { (man-years) }\end{array}$ & $\begin{array}{l}\text { Average Dose } \\
\text { (rem/quarter) }\end{array}$ \\
\hline Immediate Dismantlement & $1895^{(b, c)}$ & $270^{(d)}$ & 1.7 & $380^{(d)}$ & 1.2 \\
\hline $\begin{array}{l}\text { Preparations for } \\
\text { Passive Safe Storage }\end{array}$ & $375^{(e)}$ & $130^{(f)}$ & 0.7 & $210^{(f)}$ & 0.5 \\
\hline Entombment (Scenario 1) & $1684^{(9)}$ & $280^{(h)}$ & 1.5 & $380^{(h)}$ & 1.1 \\
\hline (Scenario 2) & $1573^{(9)}$ & $240^{(i)}$ & 1.6 & $340^{(i)}$ & 1.2 \\
\hline
\end{tabular}

(a) Includes utility operators, laborers, and craftsmen.

(b) Based on Table I.4-1 in Appendix I.

(c)All values rounded to two significant figures.

(d) Based on Table I.2-3.

(e) Based on Table J.6-1 in Appendix J.

(f) Based on Table J.4-1.

(g)Based on Table K.4-1 in Appendix K.

(h)Based on Table K.2-2.

(i)Based on Section K.2.2 in Appendix K.

The surveillance and maintenance staff is exposed to the residual radiation levels present in the reference BWR during the continuing care period. During this period, the radiation levels continually decline by radioactive decay. The dominant isotope during continuing care is again assumed to be ${ }^{60} \mathrm{Co}$. Table 11.2-5 lists a summary of the man-hours of labor and man-rem of occupational radiation dose accumulated for continuing care periods of $10,30,50$, and 100 years. The majority of the occupational dose is accumulated during the first 30 years of continuing care. 
TABLE 11.2-5. Summary of the Estimated Occupational

Radiation Dose for Continuing Care

\begin{tabular}{cccc}
$\begin{array}{c}\text { Time After } \\
\text { Final Shutdown } \\
\text { (years) }\end{array}$ & $\begin{array}{c}\text { Accumulated } \\
\text { Exposure } \\
\text { (man-hours) }\end{array}$ & $\begin{array}{c}\text { Accumulated } \\
\text { Radiation Dose } \\
\text { (man-rem) }\end{array}$ \\
\cline { 1 - 1 } 10 & 1680 & 1.3 \\
30 & 5880 & 6.5 \\
50 & 10000 & 10.0 \\
100 & 20600 & 10.0
\end{tabular}

(a) The facility radiation levels are assumed to decay at a rate governed by the half-life of $60 \mathrm{Co}$.

The estimated external occupational radiation doses for decommissioning the reference BWR are summarized in Table 11.2-6. The total occupational dose for immediate dismantlement is given, and a breakdown of safe storage and deferred dismantlement into preparations for safe storage, continuing care, and deferred dismantlement is presented. Occupational radiation doses for deferred dismantlement are calculated by reducing the immediate dismantlement doses in proportion to the decay of ${ }^{60}$ Co over the time period of interest. Thus, if a given task performed immediately after shutdown caused a radiation dose proportional to the amount of radioactive material present, $N_{0}$, that same task performed $t$ years later during deferred dismantlement would cause a dose proportional to the amount of radioactive material present at that time, $N(t)=N_{0} e^{-\lambda t}$, where $\lambda$ is the decay constant for ${ }^{60} C_{0}$ in years. This is a conservative assumption since the radiation levels at reactor shutdown are controlled by radionuclides with half-lives shorter than that of ${ }^{60} \mathrm{Co}$. The decline in the radiation dose rate from the decay of residual radioactive contamination is controlled by ${ }^{60}$ Co until about 60 years after reactor shutdown, as shown in Figure 7.4-3 in Chapter 7. Reducing the immediate dismantiement occupational radiation doses by the normalized dose rate from the total dose curve of Figure 7.4-3 is necessarily based on the assumption that the decommissioning operations are performed the same way at each time period. For times of 30 years or longer after shutdown, preparations for passive safe storage 
TABLE 11.2-6. Estimated Occupational Radiation Dose from Various Dismantlement Alternatives

\begin{tabular}{|c|c|c|c|c|c|}
\hline \multirow{2}{*}{$\begin{array}{r}\text { Years } \\
\text { After } \\
\text { Reactor } \\
\text { Shutdown } \\
\end{array}$} & \multicolumn{5}{|c|}{ Occupational Radiation Dose (man-rem) } \\
\hline & $\begin{array}{c}\text { Immediate } \\
\text { Dismant lement }\end{array}$ & $\begin{array}{l}\text { Preparations for } \\
\text { Passive Safe Storage }\end{array}$ & $\begin{array}{l}\text { Continuing } \\
\text { Care }\end{array}$ & $\begin{array}{c}\text { Deferred } \\
\text { Dismantlement }\end{array}$ & Totals \\
\hline 0 & 1845 & -- & -- & -- & 1845 \\
\hline 10 & -- & 375 & 1.3 & 495 & 871 \\
\hline 30 & -- & 375 & 6.5 & 36 & 418 \\
\hline 50 & -- & 375 & 10.0 & 3 & 388 \\
\hline 100 & -- & 375 & 10.0 & $<1$ & 386 \\
\hline
\end{tabular}

contributes most of the total occupational radiation dose accumulated during the total decommissioning program of safe storage with deferred dismantlement.

The estimates of the occupational radiation dose are sensitive to management philosophy and to the decommissioning methods used. Administrative controls are assumed to be in place that keen radiation records for each individual and ensure that no one worker exceeds recommended limits. Estimates contained in Table 11.2-6 are based on decommissioning methods that use shielding devices and highly trained technicians. Different basic assumptions, decommissioning procedures, or increased manpower may change these occupational radiation dose estimates significantly.

\subsubsection{Industrial Safety}

Injuries and fatalities can result among decommissioning workers because of industrial accidents, but proper management and safety practices can minimize the occurrence of such accidents. Estimates of injuries and fatalities during decommissioning are based on data collected by the U.S. AEC for the period 1943-1970. (1) Table 11.2-7 lists the estimated worker injuries and fatalities for the three decommissioning modes considered in this study. The work categories shown in the table divide the total effort into three categories of accident potential. (2) As shown in the table, about 7 lost-time injuries could result during immediate dismantlement, about 3 during preparations for 


\section{TABLE 11.2-7. Estimated Occupational Lost-Time Injuries and Fatalities from Decommissioning Operations $(a)$}

\begin{tabular}{|c|c|c|c|c|c|c|c|c|c|c|c|}
\hline \multirow[b]{2}{*}{ Category of Effort } & \multicolumn{2}{|c|}{$\begin{array}{c}\text { Frequency } \\
\text { (Accldents/106 man-hrs) }\end{array}$} & \multicolumn{3}{|c|}{$\begin{array}{c}\text { Immed a a te } \\
\text { Dismantlement }\end{array}$} & \multicolumn{3}{|c|}{$\begin{array}{l}\text { Preparations for } \\
\text { Passive Safe Storage }\end{array}$} & \multicolumn{3}{|c|}{$\begin{array}{l}\text { Entombment } \\
\text { Scenario I }\end{array}$} \\
\hline & $\begin{array}{l}\text { Lost-Time } \\
\text { Injuries }\end{array}$ & Fatalities & $\operatorname{man-hrs}(c)$ & $\begin{array}{l}\text { Lost-Time } \\
\text { Injuries }\end{array}$ & Fatalities & man-hrs (d) & $\begin{array}{l}\text { Lost-Time } \\
\text { Injuries }\end{array}$ & Fatalities & man-hrs $(e)$ & $\begin{array}{l}\text { Lost-Time } \\
\text { Injuries }\end{array}$ & Fatalities \\
\hline Heavy Construction ${ }^{(f)}$ & 10 & $4.2 \times 10^{-2}$ & $3.4 \times 10^{5}$ & 3.4 & $1.4 \times 10^{-2}$ & $N / A(g)$ & $N / A$ & $N / A$ & $3.0 \times 10^{5}$ & 3.0 & $1.3 \times 10^{-2}$ \\
\hline Light Construction & 5.4 & $3.0 \times 10^{-2}$ & $4.2 \times 10^{5}$ & 2.3 & $1.3 \times 10^{-2}$ & $4.0 \times 10^{5}$ & 2.2 & $1.2 \times 10^{-2}$ & $4.6 \times 10^{5}$ & 2.5 & $1.4 \times 10^{-2}$ \\
\hline Operational Support & 2.1 & $2.3 \times 10^{-2}$ & $4.7 \times 10^{5}$ & $\underline{0.98}$ & $1.1 \times 10^{-2}$ & $3.5 \times 10^{5}$ & $\underline{0.74}$ & $8.0 \times 10^{-3}$ & $5.0 \times 10^{5}$ & 1.0 & $1.2 \times 10^{-2}$ \\
\hline olars & & & $1.2 \times 10^{6}$ & 6.7 & $3.8 \times 10^{-2}$ & $7.5 \times 10^{5}$ & 2.9 & $2.0 \times 10^{-2}$ & $1.3 \times 10^{6}$ & 6.5 & $3.9 \times 10^{-2}$ \\
\hline
\end{tabular}

(a) Estimates of man-hours, injuries, and fatalities are rounded to two significant figures.

(b) Lost-time injuries and fatality frequences are from Reference 1.

c) Estimates of man-hours of heavy construction are based on information in Table I.2-1 in Appendix I. Estimates of man-hours of light construction and operational support are based on information in Table 1.2-3.

(d) Estimates of man-hours of light construction and operational support are based on information in Table J.4-1 in Appendix J. No heavy construction tasks are performed during preparations for passive safe storage.

(e) Estimates of man-hours of heavy construction are based on information in Table K.2-1 in Appendix K. Estimates of man-riours of 11 ght construction and operational support are based on information in Table K.2-2.

f) Heavy construction involves demolition tasks such as removal of piping, equipment, and concrete.

a) $N / A=$ Not Applicable. 
passive safe storage, and about 6 during entombment scenario 1. Less than 1 death to decommissioning workers is calculated to occur during any of the three modes.

Estimates of the number of injuries and fatalities that could occur among the maintenance and surveillance staff during various period of continuing care are listed in Table 11.2-8. As shown in this table, less than 1 injury and much less than 1 death are calculated to occur during 100 years of continuing care.

\subsection{PUBLIC SAFETY ASPECTS OF DECOMMISSIONING THE REFERENCE BWR}

The consequences of atmospheric releases of radioactivity during routine BWR decommissioning tasks are determined by calculating radiation doses to the maximum-exposed individual and to the population residing within $80 \mathrm{~km}$ of the site. Radiation exposure pathways considered for routine atmospheric releases are direct external exposure, inhalation, and ingestion of food products. The consequences of postulated accidents are determined by calculating inhalation radiation doses to the maximum-exposed individual. The radiation dose calculations for both the routine and accidental releases use the environmental information discussed in Appendix $B$ and the radiation dose models and parameters discussed in Appendix F.

Details of the atmopsheric release calculations and listings of decommissioning mode-, building-, and task-specific radiation doses are found in Appendix N. These calculations use current data and methodology to quantify the atmospheric releases and obtain results that are useful in comparing the alternative decommissioning tasks and modes discussed in this study. The following sections contain summaries of the calculated radiation doses to the public during immediate dismantlement, preparations for passive safe storage, and entombment of the reference BWR.

\subsubsection{Public Radiation Doses from Routine Decommissioning Tasks}

Loss of confinement of radioactive materials resulting in public radiation exposure is a primary safety concern during decommissioning. The atmospheric releases of radioactivity during decommissioning are calculated (in Appendix $\mathrm{N}$ 
TABLE 11.2-8. Estimated Lost-Time Injuries and Fatalities to Decommissjoning Workers from Continuing Care During Passive Safe Storage (a)

Frequency

\begin{tabular}{|c|c|c|c|c|c|c|c|c|c|c|c|}
\hline \multirow{2}{*}{ Task } & \multirow{2}{*}{$\begin{array}{l}\text { Estimated } \\
\text { man-hrs/year }(b)\end{array}$} & \multicolumn{2}{|c|}{$\begin{array}{c}\text { Frequency } \\
\text { (Accidents } / 10^{6} \text { man-hrs) }\end{array}$} & & \multirow{2}{*}{\multicolumn{2}{|c|}{50 -Years }} & \multirow{2}{*}{\multicolumn{2}{|c|}{100 -Years }} \\
\hline & & Lost-Time & Fatalities & $\frac{10-1}{\text { Injuries }}$ & $\frac{\text { ears }}{\text { fatalities }}$ & $\frac{30-y}{\text { Injuries }}$ & $\frac{\text { ears }}{\text { Fataities }}$ & & & & \\
\hline Surveillance & 2400 & 2.1 & $2.3 \times 10^{-2}$ & $5.0 \times 10^{-2}$ & $5.5 \times 10^{-4}$ & $1.5 \times 10^{-1}$ & $1.6 \times 10^{-3}$ & $2.5 \times 10^{-1}$ & $2.8 \times 10^{-3}$ & $5.0 \times 10^{-1}$ & $5.5 \times 10^{-3}$ \\
\hline Maintenance & 200 & 5.4 & $3.0 \times 10^{-2}$ & $1.1 \times 10^{-2}$ & $6.0 \times 10^{-5}$ & $3.3 \times 10^{-2}$ & $1.8 \times 10^{-4}$ & $5.5 \times 10^{-2}$ & $3.0 \times 10^{-4}$ & $1.1 \times 10^{-1}$ & $6.0 \times 10^{-4}$ \\
\hline $\begin{array}{l}\text { Accumulated } \\
\text { Totals }\end{array}$ & 2600 & & & $6.1 \times 10^{-2}$ & $6.1 \times 10^{-4}$ & $1.8 \times 10^{-1}$ & $1.8 \times 10^{-3}$ & $3.0 \times 10^{-1}$ & $3.1 \times 10^{-3}$ & $6.1 \times 10^{-1}$ & $6.1 \times 10^{-3}$ \\
\hline
\end{tabular}

(a)Estimates of man-hours, injuries, and fatalities are rounded to two significant figures.

(b)Labor estimates during continuing care are from Table J.4-2 in Appendix J.

c) Lost-time and fatality frequencies are from Reference 1. 
of Volume 2) to be smaller than the annual releases from operating BWR power stations. (3) This is because of the removal of the reactor fuel, the use of chemical contamination, the use of procedures that are carefully designed to minimize atmospheric releases, the use of existing HVAC systems, and the addition of HEPA-filtered ventilation systems to ensure proper air flow in isolated work areas.

The primary sources of radioactive effluents from routine decommissioning tasks are: radioactive liquid aerosols during chemical decontamination, vaporized radioactive metal during equipment or piping removal, and radioactive concrete dust during concrete removal. Equipment, piping, and concrete removal tasks are kept to a miniumum during preparations for passive safe storage.

A complete discussion of methods used to calculate atmospheric releases during decommissioning is contained in Appendix $N$. The atmospheric releases are calculated for tasks during immediate dismantlement, preparations for passive safe storage, and entombment. Decommissioning tasks are considered in three major buildings: the Reactor Building, the Turbine Generator Building, and the Radwaste and Control Building. The atmospheric releases for each task are associated with specific reference radionuclide inventories (developed in Chapter 7) to permit accurate radiation dose calculations.

Tables 11.3-1 and 11.3-2 contain summaries of the calculated radiation doses to the maximum-exposed individual and to the population residing within $80 \mathrm{~km}$ of the reference BWR site. These radiation doses use the calculated atmospheric releases for each task, mode, and building. The radiation doses 1isted in Tables 11.3-1 and 11.3-2 are the first-year dose and fifty-year committed radiation dose equivalent to total body and lung. The calculated doses for immediate dismantlement and entombment are quite similar, while the doses for preparations for passive safe storage are about 10 to 100 times lower. These radiation doses are extremely small by comparison to the range of annual radiation dose to an individual from natural background in. the United States (from 80 to 170 mrem per year). (4) These calculated radiation doses are also smaller than the allowable radiation doses to the public from operating LWR facilities set forth in Appendix I of 10 CFR 50. (5) 
TABLE 11.3-1. Summary of Calculated Radiation Doses to the Maximum-Exposed Individual from Atmospheric Releases of Radionuclides During Routine Decommissioning Tasks

Mode/Building

Immediate Dismantlement

Primary Containment

Reactor Building

Turbine Generator

Building

Radwaste and Control

Building

Totals

Preparations for Passive Safe Storage

Reactor Building

Turbine Generator

Building

Radwaste and Control

Building

Totals
First-Year Dose (rem)
Total Body Lung

$7.7 \times 10^{-7}$

$2.3 \times 10^{-6}$

$1.1 \times 10^{-6}$

$3.4 \times 10^{-6}$

$9.1 \times 10^{-7}$

$1.5 \times 10^{-6}$

$6.7 \times 10^{-6}$

$5.3 \times 10^{-7}$

$1.6 \times 10^{-6}$

$5.9 \times 10^{-7}$

$1.0 \times 10^{-5}$

$\frac{2.3 \times 10^{-6}}{4.7 \times 10^{-6}} \frac{7.3 \times 10^{-6}}{1.5 \times 10^{-5}}$

$\frac{2.5 \times 10^{-6}}{5.5 \times 10^{-6}}$

$\frac{2.0 \times 10^{-5}}{4.1 \times 10^{-5}}$

Fifty-Year Committed Dose Equivalent (rem) Lung
$1.5 \times 10^{-8}$
$3.2 \times 10^{-8}$
$2.6 \times 10^{-8}$
$9.5 \times 10^{-8}$
$5.8 \times 10^{-9}$
$1.6 \times 10^{-9}$
$7.6 \times 10^{-9}$
$4.6 \times 10^{-8}$
$\frac{3.4 \times 10^{-7}}{3.6 \times 10^{-7}} \frac{1.0 \times 10^{-6}}{1.0 \times 10^{-6}}$
$\frac{3.8 \times 10^{-7}}{4.1 \times 10^{-7}}$
$\frac{3.0 \times 10^{-6}}{3.1 \times 10^{-3}}$

Entombment Scenario 1

Primary Containment

Reactor Building

$1.4 \times 10^{-7}$

$5.3 \times 10^{-7}$

$1.6 \times 10^{-7}$

$1.7 \times 10^{-6}$

$1.4 \times 10^{-6}$

$2.3 \times 10^{-6}$

$1.6 \times 10^{-6}$

$1.2 \times 10^{-5}$

Turbine Generator

Building

Radwaste and Control

Building

Totals

$5.3 \times 10^{-7} 1.6 \times 10^{-6}$

$5.9 \times 10^{-7}$

$4.6 \times 10^{-6}$

$\frac{2.3 \times 10^{-6}}{4.4 \times 10^{-6}} \frac{7.3 \times 10^{-6}}{1.2 \times 10^{-5}}$

$\frac{2.5 \times 10^{-6}}{4.8 \times 10^{-6}}$

$\frac{2.0 \times 10^{-5}}{3.8 \times 10^{-5}}$ 
TABLE 11.3-2. Summary of Calculated Radiation Doses to the Population from Atmospheric Releases of Radionuclides During Routine Decommissioning Tasks $(a)$

Mode/Building

First-Year Dose (man-rem)

Fifty-Year Committed Dose Total Body Lung Equivalent (man-rem)

Total Body Lung

Immediate Dismant Tement

Primary Containment

$4 \times 10^{-4}$

$2 \times 10^{-3}$

$5 \times 10^{-4}$

$8 \times 10^{-3}$

Reactor Building

$6 \times 10^{-4}$

$3 \times 10^{-3}$

$1 \times 10^{-3}$

$1 \times 10^{-2}$

Turbine Generator Building

$3 \times 10^{-4}$

$2 \times 10^{-3}$

$3 \times 10^{-4}$

$5 \times 10^{-3}$

Radwaste and

Control Building

Totals

$\frac{1 \times 10^{-3}}{2 \times 10^{-3}}$

$\frac{7 \times 10^{-3}}{1 \times 10^{-2}}$

$\frac{1 \times 10^{-3}}{3 \times 10^{-3}}$

$\frac{3 \times 10^{-2}}{5 \times 10^{-2}}$

Preparations for

Passive Safe Storage

Reactor Building

Turbine Generator Building

Radwaste and

Control Building

Totals
$9 \times 10^{-6}$

$4 \times 10^{-6}$

$\frac{2 \times 10^{-4}}{2 \times 10^{-4}}$

$9 \times 10^{-5}$

$2 \times 10^{-4}$

$3 \times 10^{-4}$

$\frac{1 \times 10^{-3}}{2 \times 10^{-3}}$
$2 \times 10^{-3}$

$3 \times 10^{-5}$

$2 \times 10^{-5}$

$\frac{1 \times 10^{-3}}{1 \times 10^{-3}}$

$5 \times 10^{-4}$

$4 \times 10^{-3}$

$\frac{7 \times 10^{-3}}{1 \times 10^{-2}}$
$2 \times 10^{-5}$

$1 \times 10^{-4}$

$5 \times 10^{-6}$

$8 \times 10^{-6}$

Turbine Generator Building

Radwaste and Control Building

Totals

(a)All calculated doses are rounded to one significant figure, and are for the population of 3.5 million people residing within an $80-\mathrm{km}$ radius of the site. 
The release of radionuclides during continuing care is expected to be negligible compared to the release during preparations for passive safe storage. This is because of the rugged construction of the BWR facility, the erection of rigid barriers preventing migration of radionuclides, and the limited human contact during surveillance and maintenance operations. Thus, no public radiation doses are calculated for continuing care. Similarly, since the calculated radiation doses for immediate dismantlement are sma11, and since the radioactivity levels are significantly reduced by radioactive decay during continuing care, public radiation doses for deferred dismantlement are expected to be insignificant and are not calculated.

\subsubsection{Public Radiation Doses from Postulated Accidents During Decommissioning}

The consequences of postulated decommissioning accidents that result in atmospheric releases of radioactivity are determined by calculating the inhalation dose to the maximum-exposed individual. Immediate dismantlement tasks are analyzed, and postulated accidents are discussed in Section $\mathrm{N} .2 .2$ of Appendix $N$. Using engineering judgment, a general estimate of the frequency of occurrence of the level of atmospheric release is made for each accident. The frequency of occurrence is judged to be "high" if the occurrence of a release of similar magnitude per year is greater than $10^{-2}$, "medium" if between $10^{-2}$ and $10^{-5}$, and "low" if less than $10^{-5}$. While it is beyond the scope of this study to evaluate every potential accident for each decommissioning mode, an attempt is made to identify the most significant potential accidents associated with immediate dismantlement tasks. Accidents during preparations for passive safe storage and entombment are determined by direct comparison with immediate dismantlement, with no attempt at further analysis. Thus, several of the accidents postulated for immediate dismantlement do not apply to the other two modes, since they do not involve the removal of activated concrete or components.

A summary of the postulated accidents considered in this study is given in Table 11.3-3. These accidents are listed in order of decreasing magnitude of atmospheric release. First-year radiation doses and fifty-year committed radiation dose equivalents are listed for the lung of the maximum-exposed individual. The accident that is postulated to result in the largest atmospheric release of 
TABLE 11.3-3. Summary of Maximum-Exposed Individual Radiation Doses from Postulated BWR Decommissioning Accidents

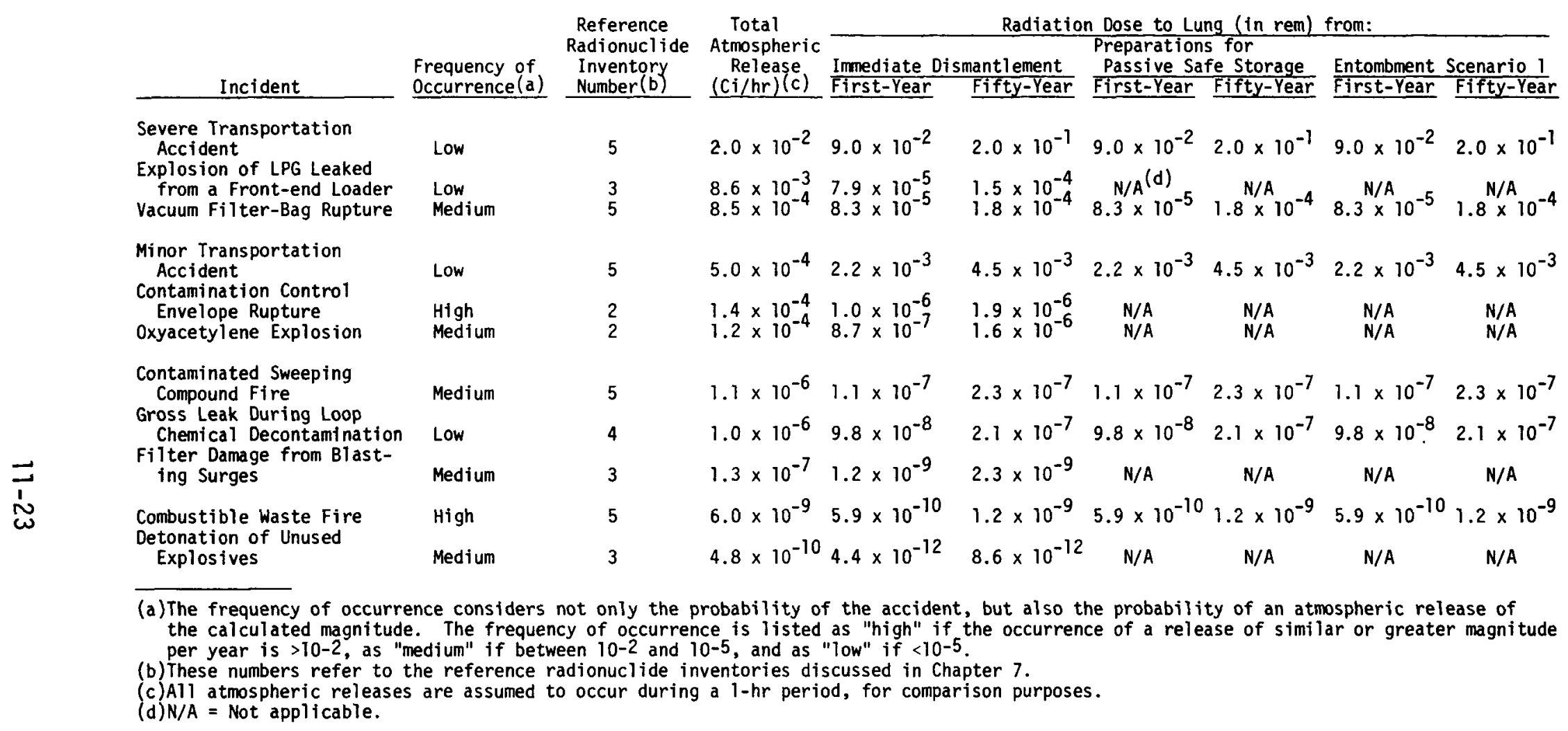


radioactivity is the explosion of liquid petroleum gas (LPG) leaked from a front end loader. This accident is assumed to occur in the ventilation duct with enough force to cause failure of the HEPA filter system. It is calculated that $8.6 \times 10^{-3}$ curies of reference radionuclide inventory 3 could be released. The frequency of occurrence of this accident with this magnitude of release is judged to be low. Transportation accidents, which are included in Table 11.3-3 for comparison purposes, are discussed in Section 11.4 .

\subsection{TRANSPORTATION SAFETY}

Spent reactor fuel and radioactive wastes collected during decommissioning. are assumed to be shipped offsite as part of planned decommissioning tasks. Spent fuel is assumed to be shipped by rail in an IF-300 shipping cask to a repository located $2400 \mathrm{~km}$ away. Radioactive waste materials are assumed to be shipped by truck to a disposal site $800 \mathrm{~km}$ away. The method used to estimate radiation doses to transportation workers and to members of the public along the transportation route is based on information in Reference 6 . The discussion of transportation accidents resulting in atmospheric releases of radioactivity is based on the methods contained in Reference 7 . The following subsections contain a summary of the radiation dose calculations discussed in Section N.5 of Appendix N, as well as estimates of casualties resulting from traffic accidents during decommissioning transportation tasks. Radiation doses received by workers unloading the radioactive materials at a repository or disposal site are not estimated in this study, since they are assumed to occur at a separate licensed facility.

\subsubsection{Radiation Doses from Routine Decommissioning Transportation Tasks}

Department of Transportation (DOT) regulations ${ }^{(8)}$ set the following exposure limits for shipments of radioactive material:

- $1000 \mathrm{mR} / \mathrm{hr}$ at $1 \mathrm{~m}$ from the external surface of any package transported in a closed vehicle

- $200 \mathrm{mR} / \mathrm{hr}$ at the external surface of the vehicle 
- $10 \mathrm{mR} / \mathrm{hr}$ at any point $2 \mathrm{~m}$ from the vehicle

- $2 \mathrm{mR} / \mathrm{hr}$ at any normally occupied position in the vehicle.

Each shipment is assumed to contain enough radioactive material (either spent fuel or waste) to result in the maximum exposure rates allowed by the above regulations.

The estimated radiation doses from rail shipment of spent fuel are listed in Table 11.4-1. Forty-three shipments of spent fuel are required. Each train is assumed to transport only one cask. The estimated radiation doses from 43 train shipments of spent fuel are: 5.4 man-rem to train brakemen and 0.46 man-rem to the public along the transportation route. These doses are assumed to be identical for the three decommissioning modes considered in this study.

Radioactive waste shipment requirements for the three decommissioning modes are discussed in chapter 9. The number of shipments required are: 1495 for immediate dismantlement, 318 for preparations for passive safe storage, 985 for entombment scenario 1, and 728 for entombment scenario 2. The calculated radiation doses from routine waste transportation tasks are listed in Table 11.4-2. TABLE 11.4-1. $\begin{aligned} & \text { Calculated Radiation Dose from Rail Transport } \\ & \text { of Spent Fuel(a) }\end{aligned}$

\begin{tabular}{ccc} 
Group & $\begin{array}{c}\text { Radiation Dose Per } \\
\text { Shipment (man-rem) }\end{array}$ & $\begin{array}{c}\text { Total Radiation } \\
\text { Dose (man-rem) }\end{array}$ \\
\cline { 2 - 3 } $\begin{array}{c}\text { Train Brakemen } \\
\text { Total 0ccupa- } \\
\text { tional }\end{array}$ & 0.12 & $\underline{5.4}$ \\
$\begin{array}{c}\text { Onlookers } \\
\text { General Public }\end{array}$ & 0.005 & 5.4 \\
Total Public & 0.006 & 0.22 \\
& & $\underline{0.24}$
\end{tabular}

(a) A11 doses are rounded to two significant figures.

(b) Based on a total of 43 shipments of $2400 \mathrm{~km}$ each. 
TABLE 11.4-2. Calculated Radiation Dose from Routine Radioactive Waste Transportation

Mode/Group $\quad \begin{gathered}\begin{array}{c}\text { Radiation Dose } \\ \text { per Shipment } \\ (\operatorname{man}-\mathrm{rem})(a)\end{array} \\ \text { Nhipments }\end{gathered}$

Immediate Dismantlement

Truck Drivers

$6.7 \times 10^{-2} \quad 1495$

100

Garagemen

$3.3 \times 10^{-3}$

1495

5.0

Total Transportation Worker Dose

Onlookers

$5.0 \times 10^{-3}$

1495

110

General Public

$1.8 \times 10^{-3}$

1495

7.5

Total Public Dose

Preparations for Passive Safe Storage

Truck Drivers

$6.7 \times 10^{-2}$

318

21

Garagemen

$3.3 \times 10^{-3}$

318

$\frac{1.1}{22}$

Total Transportation Worker Dose

Onlookers.

$5.0 \times 10^{-3}$

1.6

General Public

$1.8 \times 10^{-3}$

318

$\frac{2.8}{10}$

Total Public Dose

318

0.6

2.2

\section{Entombment}

(Scenario 1)

Truck Drivers

$6.7 \times 10^{-2}$

985

66

Garagemen

$3.3 \times 10^{-3}$

985

3.2

Total Transportation Worker Dose

Onlookers

$5.0 \times 10^{-3}$

985

69

General Public

$1.8 \times 10^{-3}$

4.9

Total Public Dose

985

1.8

(Scenario 2)

Truck Drivers

$6.7 \times 10^{-2}$

728

49

Garagemen

$3.3 \times 10^{-3}$

728

Total Transportation Worker Dose

Onlookers

$5.0 \times 10^{-3}$

728

3.6

General Public

$1.8 \times 10^{-3}$

728

1.3

Total Public Dose

(a)Based on one-way trips of $800 \mathrm{~km}$.

(b)All doses are rounded to two significant figures. 
The largest calculated doses ocçur for immediate dismantlement, since this mode requires more waste shipments than the other two decommissioning modes. Doses of 110 man-rem to transportation workers and 10 man-rem to the public are calculated to result. Similar doses for preparations for passive safe storage and entombment scenario 1 are about $20 \%$ and $70 \%$, respectively, of the doses calculated for immediate dismantlement.

\subsubsection{Radiation Doses from Postulated Transportation Accidents}

Transportation accidents have a wide range of severities. Most accidents occur at low vehicle speeds and have relatively minor consequences. In general, as speed increases, accident severity also increases. However, accident severity is not a function of vehicle speed only. Other factors such as the type of accident, the kind of equipment involved, and the location of the accident can have an important bearing on accident severity.

Furthermore, damage to a package in a transportation accident is not directly related to accident severity. In a series of accidents of the same severity, or in a single accident involving a number of packages, damage to packages may vary from none to extensive. In relatively minor accidents, serious damage to packages can occur from impacts on sharp objects or from being struck by other cargo. Conversely, even in very severe accidents, damage to packages may be minimal.

Probabilities of rail and truck accidents and the calculation of airborne concentrations of radioactivity from such accidents are discussed in Section N.5 of Appendix N. Most of the information about moderate and severe accidents is obtained from Reference 9 . The radioactive materials that are transported in Type B packages (spent fuel and the highly activated reactor internals and pressure vessels) are in solid, noncombustible forms that are not likely to become airborne in an accident. Therefore, no accident analysis of Type $B$ packages is considered. Instead, two more realistic accidents involving combustible radioactive wastes in Type $A$ packages are defined. Both, however, are judged to have a low frequency of occurrence. The calculated radiation doses to the lung of the maximum-exposed individual, resulting from these accidents are shown in Table 11.3-3. These transportation accidents are ranked with the other postulated decommissioning accidents by order of magnitude of atmospheric release. 
The severe transportation accident is assumed to involve rupture and fire in 40 waste containers, each containing 1 curie of reference inventory 5 . The total atmospheric release is 0.02 curie and the fifty-year committed radiation dose equivalent to the lung of the maximum-exposed individual is calculated to be $0.09 \mathrm{rem}$. For the minor accident, only one package is assumed to rupture and burn. In this case, the fifty-year committed radiation dose equivalent to the lung of the maximum-exposed individual is calculated to be about 0.002 rem. 11.4.3 Casualties from Traffic Accidents

As with any transportation task, a certain potential for accidental injury or death exists from traffic accidents during decommissioning tasks. ${ }^{(6)}$ A summary of the casualties calculated to result during the transportation tasks considered in this study is shown in Table 11.4-3. As shown in this table, about 0.05 injuries and 0.004 fatalities are estimated for the 43 rail shipments of spent fuel. The number of casualties calculated for each decommissioning mode is based on the total number of waste shipments required for each mode. The largest number of casualties is calculated for immediate dismantlement, since this mode requires more waste shipments than the other two decommissioning modes. About 1.2 injuries and 0.072 fatalities are calculated to result. Similar casualties for preparations for passive safe storage and entombment scenario 1 are about $20 \%$ and $70 \%$, respectively, of the calculated immediate dismantlement casualties. 
TABLE 11.4-3. Estimated Casualties from Decommissioning Transportation Accidents $(a)$

\begin{tabular}{|c|c|c|c|c|c|c|}
\hline Transportation Task & $\begin{array}{l}\text { Accident Frequency } \\
\text { (Accidents per } \\
\text { vehicle Kilometer) }\end{array}$ & $\begin{array}{l}\text { Injuries } \\
\text { Per Accldent }\end{array}$ & $\begin{array}{l}\text { Fatalities } \\
\text { Per Accident }\end{array}$ & $\begin{array}{c}\text { Total } \\
\text { Kilometers } \\
\text { (Round Trips) } \\
\end{array}$ & $\begin{array}{l}\text { Transportation } \\
\text { Injuries }\end{array}$ & $\frac{\text { Casualties }}{\text { Fatalities }}$ \\
\hline \multicolumn{7}{|l|}{$\operatorname{RaI1}(c)$} \\
\hline Spent Fuel & $87 \times 10^{-8}$ & 27 & 02 & $21 \times 10^{5}$ & 0049 & 0.0036 \\
\hline \multicolumn{7}{|l|}{ Truck $(d)$} \\
\hline Immedrate Dismantlement & $1.0 \times 10^{-6}$ & 0.51 & 0.03 & $24 \times 10^{6}$ & 12 & 0.072 \\
\hline Preparations for Passive Safe Storage & $1.0 \times 10^{-6}$ & 051 & 003 & $51 \times 10^{5}$ & 026 & 0.015 \\
\hline Entombment Scenarro ${ }^{(e)}$ & $1.0 \times 10^{-6}$ & 051 & 0.03 & $16 \times 10^{6}$ & 0.80 & 0.047 \\
\hline
\end{tabular}

(a)Accident frequencies are from Reference 6.

(b) Casualty estimates are rounded to two significant figures.

(c) Assuming one spent fuel cask per train, 43 shipments, and a $4800-\mathrm{km}$ roundtrip distance

(d) Assuming truck transportation distance of $1000 \mathrm{~km}$ roundtrip to the burral ground and 1495 trips for 1 mmediate dismantlement,

318 for preparations for passive safe storage, and 985 for entombment scenario 1

(e) Casualties for entombment scenario 2 are less, by a factor of 728/985 


\section{REFERENCES}

1. Operational Accidents and Radiation Exposure Experiences Within the US AEC 1943-1970, WASH-1192, 1971.

2. American National Standards Institute, Method of Recording and Measuring Work Injury Experience, ANSI 216.1, 1967.

3. U.S. NRC, Radioactive Materials Released from Nuclear Power Plants (1975), NUREG-0218, March 1977.*

4. United Nations Scientific Committee on the Effects of Atomic Radiation, Ionizing Radiation: Levels and Effects, Volume 1, United Nations, pp. 29-63, 1972 .

5. Code of Federal Regulations, Title 10, Part 50, Appendix I, "Numerical Guides for Design Objectives and Limiting Conditions for Operation to Meet the Criterion 'As Low As Practicable' for Radioactive Materials in Light-Water-Cooled Nuclear Power Reactor Effluents," Superintendent of Documents, GP0, Washington, DC, 1977.

6. Directorate of Regulatory Standards, Environmental Safety of Transportation of Radioactive Materials to and from Nuclear Power Plants, WASH-1238, U.S. Atomic Energy Commission, Washington, DC, 1972.

7. Technology for Commercial Radioactive Waste Management, DOE/ET 0028, Vol. 4, Chapter 6.2, Prepared by Pacific Northwest Laboratory for the U.S. Department of Energy, Richland, WA, May 1979.

8. U.S. Code of Federal Regulations, Title 49, Parts 170-189, "Transportation," Superintendent of Documents, GP0, Washington, DC 20555, January 1977.

9. Environmental Aspects of Commercial Radioactive Waste Management, DOE/ET-0029, Volume 2, Chapter 7.3, Prepared by Pacific Northwest Laboratory for the U.S. Department of Energy, Richland, WA, May 1979.

\footnotetext{
*Available for purchase from the National Technical Information Service, Springfield, Virginia 22161.
} 


\section{COMPARISONS WITH OTHER STUDIES}

This chapter presents comparisons of this study with several past studies on decommissioning commercial nuclear power reactors.

Four studies that included analyses of the decommissioning of boiling water reactor (BWR) nuclear power plants have been published in the last four years. The first study, by a working group of the Association of German Electric Companies, Vereinigung Deutscher Elektrizitätswerke (VDEW), was published in summary form in June 1976, with an English translation a year later. (1) The second study, also from Germany, performed for the Commission of the European Communities (ECC) by Nuklear-Ingenieur-Service GmbH (NIS), was published in November 1976. (2) A third study, performed for the Atomic Industrial Forum (AIF) by the Nuclear Energy Services Division of Automation Industries, Inc. (NES), was published in November 1976. (3) The fourth decommissioning study, a section in a comparative study of coal and nuclear generating options, was completed by the Washington Public Power Supply System (WPPSS) in June 1977.

A companion study to this BWR decommissioning study, published in June 1978 with an addendum in August 1979 by Pacific Northwest Laboratory (PNL) for the Nuclear Regulatory Commission (NRC), developed detailed analyses of the decommissioning of a pressurized water reactor (PWR) nuclear power plant. $(5,6)$

The motivation for making these studies was varied; thus, their conclusions reflect the special sponsor interests and the studies' objectives.

\subsection{COMPARISON OF THIS STUDY WITH OTHER BWR STUDIES}

In the following subsections, each of the other BWR studies is described briefly. Discussions of the results of these studies and some comparisons with the results of this study follow the descriptions. 


\subsubsection{Reference 1: VDEW Study}

D. Brosche and J. Essman, "On the Decommissioning of Nuclear Power Stations," Atom und Strom, Volume 22, No. 3, pp. 81-87, (May/June 1976).

This paper is a summary of an internal report (which is in German and is not readily available) titled "Study on the Decommissioning of Nuclear Power Stations." The principal motivation for the study was to be sure that the current-generation nuclear stations met the requirements of Criterion 2.10 of the Safety Criterion for nuclear power stations, established by the Federal Government of Germany in 1974. This criterion states: "Nuclear power stations must be constructed in such a way that they can be decommissioned with continued observance of the radiation safety regulations. A plan must be made for the dismantling of the power station after final decommissioning, which will comply with the radiation safety regulations." Primarily, the study examined light water reactors, but special problems relating to high temperature reactors were also examined. The purpose of the study was to show that Criterion 2.10 could be satisfied using the present-day technology on the present designs. Also, the costs for decommissioning were considered, since these costs must be included in the power generation costs in order to generate reserves to pay for decommissioning.

An analysis estimated the inventory of radioactive materials that would be present in neutron-activated components after 40 years of operation at an assumed $80 \%$ load factor. Detailed work plans were formulated for two decommissioning alternatives: dismantlement, and safe storage. Decontamination methods, dismantlement equipment and techniques, and transport and storage of radioactive materials were examined. Only the analysis totals are available in the summary published in the open literature; therefore, a detailed comparison of the assumptions and conditions underlying these analyses with those of other analyses is not possible. However, a few important points identified from the paper are:

- The inventory of radionuclides was based on extrapolation from a smaller (250-MWe BWR) reactor, a procedure that can lead to significant overestimation of the inventory. 
- It was assumed that the spent fuel and radioactive operating wastes had been removed from the site before decommissioning work was started.

- The cost estimate was based on the summing of individual estimates rather than extrapolating from previous experience.

- Al1 radioactive components were cut into pieces that would fit into standard waste disposal drums for eventual disposal, an operation that would require a significant level of effort.

\subsubsection{Reference 2: ECC-NIS Study}

R. Bardtenschlager, D. Bottger, A. Gasch and N. Majohr, "Decommissioning of Light-Water Reactor Nuclear Power Plants," Nuclear Engineering and Design, Vol. 45, pp. 1-51, North-Holland Publishing Company, 1978.

The published abstract of this paper follows:

"This study deals with the technical and economic questions posed by the decommissioning of light-water reactor nuclear power plants of the 900-1300 MWe class, account being taken of the distinctions between boiling- and pressurized-water reactors. Possible decommissioning alternatives and the disposal or confinement of activity are discussed. It emerges from the discussion that decommissioning, and even total dismantlement of these nuclear power plants is in principle feasible.

"The activity inventory, one year after shutdown, is calculated to be about $3 \times 10^{7} \mathrm{Ci}$ for the BWR and $4 \times 10^{6} \mathrm{Ci}$ for the PWR; 40 years after shutdown these figures are reduced to $2 \times 10^{6}$ and $4 \times 10^{5} \mathrm{Ci}$, respectively.

"The decommissioning costs to be expected are also estimated. This estimate serves as the basis for an economic comparison by the present worth method. The economic comparison shows that total dismantlement after a cooling time of one year is more than four times as expensive as interim confinement followed by total dismantlement [after a] waiting period of 40 years. The present worths for immediate total dismantlement are estimated DM 200 million for the BWR and DM 170 million for the PWR; for the other alternative, they are put at DM 45 million for the BWR and DM 42 million for the PWR.

"A still-open question is posed by the final storage of the large quantities of bulky radioactive waste arising in partial or total dismantlement. Since no decision on the storage method has yet been taken, disposal in casks is stipulated as a boundary condition in the estimation of the costs, al though this is an unrealistic assumption. It is to be presumed that the costs of disposal can be reduced given appropriate final storage." 
This study presents detailed bases for the analyses and evaluations made. Sequences of operations and costs were developed for three decommissioning alternatives: immediate dismantlement, partial dismantlement with safe storage, and safe storage with deferred dismantlement.

In general, cost estimates were conservative, using upper-limit conditions. Radiation dose rates were estimated using standard calculational methods. The detailed calculation performed to estimate the inventory of neutron activated material was modeled after a 1200-MWe BWR, KRB II, at Gundremmingen. Several assumptions used in this study are:

- All of the spent fuel and radioactive operating wastes are removed from the site before decommissioning is started.

- The reactor pressure vessel in the BWR plant is lowered in the containment for secure residual confinement (entombment).

- Part of the BWR turbine is not decontaminated.

- All radioactive material is cut into pieces that will fit in 200- to 400- $\ell$ drums.

\subsubsection{Reference 3: AIF-NES Study}

W. J. Manion and T. S. LaGuardia, An Engineering Evaluation of Nuclear Power Reactor Decommissioning Alternatives, AIF/NESP-009, Atomic Industrial Forum, Inc., November 1976.

This study reports detailed analyses of the costs, occupational radiation exposure, and radioactive material volumes for disposal that result from the decommissioning of three generic reactor types: PWR, BWR, and HTGR. Three basic approaches to decommissioning were examined: immediate dismantlement, hardened safe storage (entombment), and custodial safe storage (mothballing). The latter two approaches were also examined when terminated by deferred dismantlement.

Since the reactors studied were generic rather than specific, design and site-specific details could not be treated fully. Rather, those items that were likely to be significantly influenced by design and site differences were identified for future consideration. 
Detailed work descriptions for the tasks necessary to accomplish the decommissioning were developed. From these descriptions, manpower, occupational radiation exposure, and radioactive material disposal volumes were estimated.

Calculations were made to estimate the inventories of radionuclides that would be present at the reactor facilities at shutdown and at various times thereafter. Radiation dose rate estimates were made for activated components from the reactor vessel at years after shutdown. The conclusion from this analysis was that some of the vessel components would remain sufficiently radioactive to preciude permanent entombment.

Estimates of airborne radionuclide releases to the environment resulting from decommissioning operations were also made, together with estimates of the radiation doses to the public resulting from transport of radioactive materials to disposal sites.

\subsubsection{Reference 4: WPPSS Study}

W. C. Wolkenhauer, Comparative Study of Coal and Nuclear Generating Options for the Pacific Northwest, Vol. III, Analysis of the Nuclear Option, Section 7, Decomissioning of Nuclear Power Plants, Washington Public Power Supply system, June 1977.

This study includes a section on the decommissioning of nuclear power plants. The analysis is based on a study by an engineering consultant firm that developed cost projections for dismantlement and entombment of both an 1100-MWe BWR and an 1100-MWe PWR. Cost estimates were based on the costs incurred in decommissioning the BONUS and Elk River reactors. Where additional data were needed they were obtained from "Building Construction Cost Data 1972," Robert Snow Means Company, Inc., and from "Manual of Industrial Construction Estimating and Engineering Standards," Richardson Engineering Services. The cost estimates were not site-specific. It was assumed in the study that the utility would act as the prime contractor for decommissioning. Cost development details were not included. 


\subsubsection{Discussion of BWR Decommissioning Study Results}

A11 of the BWR studies conclude that decommissioning of a large BWR can be accomplished using present-day technology. Improvements in tools and techniques will result in reduced radiation exposure and lower costs as decommissioning experience is gained. All of the studies recognize that consideration of decommissioning problems by the reactor designers would simplify some of the decommissioning operations.

Differences in approach between these studies are great enough to make detailed comparisons impossible. A total cost for immediate dismantlement is given in each study. The total costs differ, but the reasons for the differences are not readily apparent. The details of the cost estimates are included only in the AIF-NES study and in this (NRC-PNL) study.

The estimated quantities of neutron activation products in reactor structural components at the end of plant operation are shown in Table 12.1-1. These estimates are sensitive to several parameters: the composition of the reactor structural materials, the mass and spatial arrangement of the structural components, the intensity and distribution of the thermal neutron flux, the neutron capture cross sections of the structural materials, and the half-lives of the neutron activation products. The impact of the differences in estimated radionuclide inventories on the decommissioning effort and cost is not great, because much of the material is so radioactive that differences as great as a factor of 10 do not affect the basic work procedures employed in removing the material. The principal impacts are the costs of packaging, transportation, and curie surcharges at the burial site.

Estimates of occupational radiation dose for immediate dismantlement of a BWR are given in the AIF-NES study (550 man-rem) and in this NRC-PNL study (1845 man-rem). These estimates are based on detailed estimates of manhours of work and associated radiation dose rates. The differences between the AIF-NES and NRC-PNL studies reflect different levels of optimism for the effectiveness of chemical decontamination, different approaches to some of the dismantlement tasks, and different schedules for performing the work. 
TABLE 12.1-1. Estimated Inventories of Neutron-Activation Products in a Shutdown BWR

\begin{tabular}{|c|c|c|c|}
\hline Study & $\begin{array}{c}\text { Estimated } \\
\text { Inventory } \\
\text { (Ci) }\end{array}$ & $\begin{array}{l}\text { Time After } \\
\text { Shutdown (yr) }\end{array}$ & Basis of Estimate \\
\hline VDEW & $6.6 \times 10^{7}$ & 1 & $\begin{array}{l}\text { Extrapolation from calculation } \\
\text { for small reactor. }\end{array}$ \\
\hline ECC-NIS & $2.9 \times 10^{7}$ & 1 & $\begin{array}{l}\text { Detailed calculation for KRB-II- } \\
\text { type reactor. }\end{array}$ \\
\hline AIF-NES & $1.3 \times 10^{6}$ & 0 & $\begin{array}{l}\text { Detailed calculations for gen- } \\
\text { eric BWR. }\end{array}$ \\
\hline WPPSS & No Estimate & -- & -- \\
\hline NRC-PNL (This Study) & $6.6 \times 10^{6}$ & 0 & $\begin{array}{l}\text { Detailed calculations for ref- } \\
\text { erence WNP-2 BWR. }\end{array}$ \\
\hline
\end{tabular}

The total estimated costs for immediate dismantlement, which are given in the various BWR decommissioning studies, are shown in Table 12.1-2. Since the estimated costs in the different studies were made in different years, escalation factors are suggested to normalize the costs to 1978.

TABLE 12.1-2. Estimated Costs for Immediate Dismantlement of a Large BWR(a)

\begin{tabular}{|c|c|c|c|c|}
\hline Study & $\begin{array}{l}\text { Reported Cost } \\
(\$ \text { Millions) }\end{array}$ & $\begin{array}{l}\text { Year of } \\
\text { Estimate }\end{array}$ & $\begin{array}{c}\text { Suggested } \\
\text { Escalation Factor }\end{array}$ & $\begin{array}{l}\text { Estimated Cost } \\
(\$ \text { Millions })(b)\end{array}$ \\
\hline VDEW & 60 & 1975 & 1.29 & 77 \\
\hline ECC-NIS & 95 & 1976 & 1.11 & 100 \\
\hline AIF-NES & 31 & 1975 & 1.29 & 40 \\
\hline WPPSS & 19 & 1972 & 1.65 & 31 \\
\hline NRC-PNL (This Study) & & $1978^{(c)}$ & 1.0 & 67 \\
\hline
\end{tabular}

\footnotetext{
(a)All costs are rounded to two significant figures.

(b) Costs include demolition of the decontaminated structures and shipment of spent fuel.

(c) The NRC-PNL study uses the same cost factors as the NRC-PNL PWR study. 
The estimated costs, in Table 12.1-2 vary by as much as a factor of 3 . Since the German studies do not include details for the development of estimated costs, it is not possible to totally explain why the estimates in these studies are significantly greater than those made in the United States. However, the more massive containment structures of the German reactors and the need to cut all radioactive materials into pieces small enough to be packaged in $200-$ to $400-\ell$ burial drums partially explain the greater cost estimates.

It is apparent from the comparison of these studies that a realistic estimate of the cost for immediate dismantlement can be developed only by a detailed analysis of the plant being considered. This is true since design differences between plants significantly affect the costs of their decommissioning.

\subsection{COMPARISON OF THIS STUDY WITH THE NRC-PNL PWR STUDY}

Another study of interest--one that is related but not directly comparable to this BWR study--is the NRC-PNL PWR decommissioning study. $(5,6)$

\subsubsection{References 5 and 6: NRC-PNL PWR Study}

R. I. Smith, G. J. Konzek, and W. E. Kennedy, Jr., Technology, Safety and Costs of Decommissioning A Reference Pressurized Water Reactor Power

Station, NUREG/CR-0130, Prepared by Pacific Northwest Laboratory for U.S. Nuclear Regulatory Commission, July 1978.

R. I. Smith and L. M. Polentz, Technology, Safety and Costs of Decommissioning a Reference Pressurized Water Reactor Power Station - Addendum, NUREG/CR-0130, Section 4, Prepared by Pacific Northwest Laboratory for U.S. Nuclear Regulatory Commission, August 1979.

This study analyzes the technology, safety, and costs of decommissioning an 1175-MWe reference-PWR power station, using each of three modes: immediate dismantlement, safe storage with deferred dismantlement, and entombment.

Decommissioning of a PWR was found to be technically feasible with presentday technology. It was postulated in this study that further development of special equipment could reduce costs and occupational radiation doses. 
Estimates of accumulated occupational radiation dose from decommissioning a PWR were over 1200 man-rem for immediate dismantlement, over 400 man-rem for placing the facility in safe storage, about 760 man-rem for entombment with the reactor vessel internals left in place, and about 850 man-rem for entombment with the reactor vessel internals removed. The radiation dose associated with deferred dismantlement was found to depend on when dismantlement took place; a relatively small reduction in accumulated occupational radiation dose was estimated to result from deferring dismantlement beyond 30 years, with virtually no further reduction resulting from deferment beyond 50 years.

The PWR study also estimated the radiation doses received by the transportation workers and the general public as a result of transporting spent fuel and radioactive materials to disposal sites. The combined estimated radiation doses for these people were 125 man-rem for immediate dismantlement, 17 man-rem for safe storage preparations, and 20 man-rem and 25 man-rem, respectively, for entombment with and without the reactor vessel internals.

A11 costs given in the PWR study were in terms of 1978 dollars, with $25 \%$ contingencies included. The estimated costs for decommissioning a PWR by immediate dismantlement, by safe storage, and by entombment are summarized in Table 12.2-1.

The cost for continuing care during the period of safe storage was estimated to be about $\$ 80,000$ per year (including a $25 \%$ contingency).

The costs for deferred dismantlement, starting after intervals of 30,50 , and 100 years after final reactor shutdown, were estimated (in constant 1978 dollars) to be about $\$ 26$ million, $\$ 20$ million, and $\$ 20$ million, respectively. The lesser costs after the longer intervals result from having less contaminated material for packaging, shipment, and burial due to decay of the radionuclides. 
TABLE 12.2-1. Decommissioning Costs for the Reference PWR (millions of dollars)(a)

Cost Item

Activated Material Disposal

Contaminated Material Disposal

Radioactive Waste Disposal

Staff Labor

Electric Power

Equipment

Supplies

Nuclear Insurance

Contractor Services

Security and Surveillance

Entombment Barrier Installation

Subtotals

Contingencies (25\%)

Totais

Other Potential Costs

Fuel Shipment

Non-Radioactive Demolition

\begin{tabular}{|c|c|c|c|}
\hline \multicolumn{4}{|c|}{ Decommissioning Mode } \\
\hline $\begin{array}{c}\text { Immediate } \\
\text { Di smant lement }\end{array}$ & Safe Storage & $\begin{array}{c}\text { Entombment } \\
\text { (w/Internals) }\end{array}$ & $\begin{array}{c}\text { Entombment } \\
\text { SInternals Remov }\end{array}$ \\
\hline $\begin{array}{l}2.734 \\
5.183 \\
0.693\end{array}$ & $\begin{array}{l}--(b) \\
-- \\
0.544\end{array}$ & $\begin{array}{l}-\overline{-} \\
0.472 \\
0.693\end{array}$ & $\begin{array}{l}2.498 \\
0.472 \\
0.693\end{array}$ \\
\hline $\begin{array}{l}8.986 \\
3.500 \\
0.822\end{array}$ & $\begin{array}{l}3.651 \\
1.865 \\
0.075\end{array}$ & $\begin{array}{l}8.054 \\
3.500 \\
0.367\end{array}$ & $\begin{array}{l}8.617 \\
3.500 \\
0.822\end{array}$ \\
\hline $\begin{array}{l}1.559 \\
0.800 \\
0.544\end{array}$ & $\begin{array}{l}0.891 \\
0.294 \\
0.305\end{array}$ & $\begin{array}{l}7.559 \\
0.800 \\
0.434\end{array}$ & $\begin{array}{l}1.559 \\
0.800 \\
0.434\end{array}$ \\
\hline-- & $\begin{array}{l}3.200^{(c)} \\
-.\end{array}$ & $\begin{array}{l}3.586^{(d)} \\
0.310 \\
\end{array}$ & $\begin{array}{l}3.586^{(\mathrm{d})} \\
0.310\end{array}$ \\
\hline 24.821 & 10.825 & 19.775 & 23.291 \\
\hline 6.205 & 2.706 & 4.069 & 4.948 \\
\hline 31.026 & 13.531 & 23.844 & 28.275 \\
\hline
\end{tabular}

$\begin{array}{lccc}3.084 & 3.084 & 3.084 & 3.084 \\ 8.013 & -- & 6.354 & 6.354\end{array}$

(a) Number of significant figures shown is for computational completeness and does not imply accuracy to the nearest one thousand dollars.

(b) Indicates not required for this decommissioning mode.

(c) Annual surveillance and maintenance cost of $\$ 64,000$ for 50 years.

(d) Annual surveillance of $\$ 35,000$ for 100 years.

\subsubsection{Comparison of Results}

Summary estimates for the immediate dismantlement of the reference PWR and the reference BWR are given in Table 12.2-2. Although both studies were made by the same organization, most of the contributors to the BWR study were not involved in the PWR study. This resulted in some differences in assumptions and analyses.

The calculated radioactivity in the neutron-activated materials in and surrounding the reactor vessel of the reference BWR at shutdown is 38\% greater than that calculated for the reference PWR. For both reactors, the core shroud contains more radioactivity than all other neutron-activated components combined. The greater quantity of calculated radioactivity for the reference BWR can be attributed to its more massive core shroud, which is about 2.4 times the mass 
IABLE 12.2-2. Summary Information for Immediate Dismantlement of the Reference PWR and the Reference BWR

\begin{tabular}{|c|c|c|}
\hline Category & PWR & BWR \\
\hline & $4.8 \times 10^{6(a)}$ & $6.6 \times 10^{6(b)}$ \\
\hline $\begin{array}{l}\text { ccupational Dose (man-rem) } \\
\text { ismantlement Cost ( } \$ \text { million) }\end{array}$ & $\begin{array}{r}1200^{(c)} \\
{ }_{37}^{(f)}\end{array}$ & $\begin{array}{r}1845^{(d)} \\
44(g)\end{array}$ \\
\hline
\end{tabular}

(a)From Table 7.3-2, Reference 5.

(b) From Table 7.4-4, Chapter 7.

(c) From Table 11.3-1, Reference 5.

(d)From Table 11.2-1, Chapter 11.

(e)Early 1978 dollars.

(f) From Table 12.2-1.

(g)From Table 10.1-1, Chapter 10.

of the reference PWR core shroud. The estimated total radioactivity in the BWR core shroud is about 2.1 times the content in the PWR core shroud.

The estimated occupational radiation doses for immediate dismantlement of the reference PWR and the reference BWR are 1200 man-rem and 1845 man-rem, respectively. The larger occupational dose for the dismantlement of the BWR is principally due to the dose associated with removing and shipping the turbine, the main condenser, the feedwater heaters, and other process equipment and piping in the Turbine Generator Building. Equipment performing similar functions in the PWR was assumed to be uncontaminated. The radiation dose accumulated during dismantlement of the Turbine Generator Building of the reference BWR is partially offset by the radiation dose accumulated during dismantlement of the pressurizer and steam generators in the reference PWR.

The estimated costs for immediate dismantlement of the reference BWR are significantly greater than those for the reference PWR. About $85 \%$ of the difference is due to the greater cost for staff labor in the BWR study.

In the PWR study, it was assumed that all of the decommissioning workers could receive radiation doses of up to 3 rem per quarter. No attempt was made on a task-by-task basis to adjust the staff size or manpower loadings if the average radiation dose to the hands-on workers did not exceed 3 rem per quarter. 
In this BWR study, however, it is assumed that the supervisors, utility operators, and health physics technicians are long-time radiation workers whose annual exposure is limited to 5 rem per year by the formula $5(\mathrm{~N}-18)$ given in 10 CFR 20.101(b)(2). The craftsmen and the laborers are assumed to have had little previous radiation exposure and can receive radiation doses of up to 3 rem per quarter (within the constant of the $5(\mathrm{~N}-18)$ formula). As a result, manpower requirements for this BWR study are estimated not only on the basis of the number of workers needed to physically accomplish the work, but also on the basis of providing enough workers to assure compliance with the assumed radiation dose limits outlined above. This analysis basis necessitates the employment of a significantly larger work force for dismantlement of the BWR than would have been the case under the straight 3-rem-per-quarter basis assumed for the PWR study. It is estimated that the staff labor costs for dismantlement of the reference BWR would be reduced by about $\$ 7$ million if all of the workers were permitted to receive a radiation dose of up to 3 rem per quarter. 


\section{REFERENCES}

1. D. Brosche and J. Essman, "On the Decommissioning of Nuclear Power Stations," Atom und Strom, Volume 22, No. 3, pp. 81-87, (May/June 1976).

2. R. Bardtenschlager, D. Bottger, A. Gasch, and N. Majohr, "Decommissioning of Light Water Reactor Nuclear Power Plants," Nuclear Engineering and Design, Vo1. 45, pp. 1-51, North-Holland Publishing Company, 1978.

3. W. J. Manion and T. S. LaGuardia, An Engineering Evaluation of Nuclear Reactor Decommissioning Alternatives, AIF/NESP-009, Atomic Industrial Forum, Inc., November 1976.

4. W. C. Wolkenhauer, Comparative Study of Coal and Nuclear Generating Options for the Pacific Northwest, Vol. III, Analys is of the Nuclear Option, Section 7, Decommissioning of Nuclear Power Plants, Washington Public Power Supply System, June 1977.

5. R. I. Smith, G. J. Konzek, and W. E. Kennedy, Jr., Technology, Safety and Costs of Decommissioning A Reference Pressurized Water Reactor Power Station, NUREG/CR-0130, Prepared by Pacific Northwest Laboratory for U.S. Nuclear Regulatory Commission, July 1978.*

6. R. I. Smith and L. M. Polentz, Technology, Safety and Costs of Decommissioning a Reference Pressurized Water Reactor Power Station - Addendum, NUREG/CR-0130, Section 4, Prepared by Pacific Northwest Laboratory for U.S. Nuclear Regulatory Commission, August 1979.*

ॠAvailable for purchase from the NRC/GPO Sales Program, U.S. Nuclear Regulatory Commission, Washington, D.C. 20555, and the National Technical Information Service, Springfield, Virginia 22161. 
1 


\section{CHAPTER 13}

\section{CONSIDERATIONS FOR DECOMMISSIONING FACILITATION}

The higher cost of decommissioning nuclear power plants relative to nonnuclear power plants results from the radiation dose rates that require remote operations, contamination control, radiological surveillance, and radiological protection; the inefficiencies in using decommissioning personnel because of these radiation dose rates; the large volumes of radioactive waste that require special handling, packaging, and disposal; and the massive concrete and stee 1 structures that require special dismantling techniques.

Experience has shown that steps can be taken to minimize the effect of these circumstances during decommissioning or, stated another way, to facilitate decommissioning. Some of these steps must be taken early in the design of a boiling water reactor (BWR), while others may be taken during its operating lifetime or even during decommissioning. To be effective, a facilitation technique must reduce the radiation dose and/or the volume of radioactive waste during decommissioning, at a reasonable cost and without adversely impacting the normal operation of the facility. Ideally, an effective technique will provide similar benefits during the BWR's operating years. Decommissioning facilitation techniques have been described for light water reactors in general and for pressurized water reactors in particular in References 1 and 2, respectively. Techniques discussed in Reference 1 that might facilitate the decommissioning of a BWR are summarized in this chapter.

\subsection{DECOMMISSIONING FACILITATION ISSUES}

This section contains a discussion of the regulatory requirements as well as the potential radiation dose reduction, cost, and cost-benefit considerations of decommissioning facilitation techniques.

\subsubsection{Regulatory Requirements}

Regulatory requirements pertinent to decommissioning are discussed in Chapter 5 of this study and also in Reference 3. Regulatory requirements 
related to the facilitation of decommissioning for nuclear power plants are non-existent. However, 10 CFR Part 50, App. F.4 states: "A design objective for fuel reprocessing plants shall be to facilitate decontamination and removal of all significant radioactive wastes at the time the facility is permanently decommissioned." The intent of this regulation can logically be extended to BWRs. Also, NRC Regulatory Guide 8.8, Information Relevant to Ensuring that Occupational Radiation Exposures at Nuclear Power Stations Will Be As Low As Is Reasonably Achievable points out that "Design concepts and station features should reflect consideration of the activities of station personnel (such as ... decontamination and decommissioning) that might be anticipated and that might lead to personnel exposure to substantial sources of radiation."

In summary, the available regulatory guidance indicates that, to facilitate decommissioning, early attention should be given to the following: design, location, accessibility, and shielding of equipment and components; adequate record keeping; construction materials and their finishing; decontamination techniques; and special dismantling tools, techniques, and equipment.

\subsubsection{Radiation Dose Reduction Considerations}

The reduction of occupational radiation doses to a practical minimum is an important consideration during decommissioning, just as it is during plant operation. The standard radiation control techniques of time, distance, and shielding are used during decommissioning. In addition, the safe storage decommissioning mode can itself be considered a decommissioning facilitation technique in that it allows time for radioactivity decay, thereby reducing potential radiation dose to decommissioning personnel. Another decommission facilitation technique is to concentrate radiation sources in one place for easier shielding or remote handling. However, it should be recognized that radioactivity is not reduced or eliminated by this technique, but is merely rearranged for more convenient handling.

It is also important to recognize where the greatest opportunities for saving radiation dose exist. Tables 11.2-1, 11.3-1, 11.3-2, 11.4-1, and 11.4-2 in Chapter 11 show the occupational and public radiation doses for immediate dismantlement of the reference BWR. The combined occupational and public 
radiation dose from immediate dismantlement activities is about 1970 man-rem. If a decommissioning facilitation technique saves radiation dose during operation as well as during decommissioning of the BWR, the overall benefit becomes much greater. Recent data indicate that the average annual occupational radiation dose incurred in operating BWRs in 1976 was 550 man-rem and that this dose is increasing. $(4,5)$ Thus, over a 30 -year plant operating period, the total accumulated occupational dose could conservatively amount to 16,500 man-rem.

No estimates of radiation dose reduction are given in this chapter (see Reference 1 for this information). However, the discussion of a specific decommissioning facilitation technique indicates whether or not a saving in operational radiation dose, in addition to the reduction in decommissioning dose, might be expected from the technique's use.

\subsubsection{Cost Considerations}

Most decommissioning facilitation techniques have a capital cost and an operating-cost associated with them. Cost savings may result, however, from increased efficiencies in decommissioning or from reduced volumes of radioactive materials requiring disposal. Most importantly, if the technique reduces the length of outages during the BWR operating life and the utility purchases less replacement power from outside its own system, then for the reference BWR, nearly $\$ 500,000$ (in 1978 dollars) will be saved each additional day the plant remains in operation. These savings, in many cases, will repay the cost of the facilitation technique.

\subsubsection{Cost-Benefit Considerations}

One method of stating a decommissioning facilitation cost benefit is to state the cost per occupational man-rem saved. Such cost benefits have been calculated for a PWR and lie in a range of no cost to several million dollars per man-rem saved. (1) These calculations are not repeated here. The reader is referred to Reference 1 for a more complete discussion.

\subsection{DECOMMISSIONING FACILITATION TECHNIQUES}

This section presents a discussion of possible decommissioning facilitation techniques. Table 13.2-1 summarizes these techniques. Most techniques 
TABLE 13.2-1. Summary of Possible Decommissioning Facilitation Techniques

\begin{tabular}{|c|c|c|c|c|}
\hline $\begin{array}{l}\text { Decommissioning } \\
\text { Facilitation } \\
\text { Technique } \\
\end{array}$ & Period Implementation (a) & $\begin{array}{c}\text { Occupational Radiation } \\
\text { During } \\
\text { Operation } \\
\end{array}$ & $\begin{array}{c}\text { Dose Reduction } \\
\text { During } \\
\text { Decommissioning }\end{array}$ & $\begin{array}{l}\text { Unit Cost-Benefit }{ }^{(b)} \\
\text { (dollars man-rem saved) }\end{array}$ \\
\hline $\begin{array}{l}\text { Improved Docum- } \\
\text { entation }\end{array}$ & C & Yes & Yes & $T$ \\
\hline Improved Access & C & Yes & Yes & $T$ \\
\hline $\begin{array}{l}\text { Different Mate- } \\
\text { rials in } \\
\text { Reactor Ves- } \\
\text { sel Internals }\end{array}$ & C & Yes & Yes & $T$ \\
\hline $\begin{array}{l}\text { Concrete Protec- } \\
\text { tion }\end{array}$ & C & No & Yes & 0 \\
\hline \multicolumn{5}{|l|}{$\begin{array}{l}\text { Improved Shield- } \\
\text { ing }\end{array}$} \\
\hline $\begin{array}{l}\text { Pipe Shielding } \\
\text { Shielded Vehicle }\end{array}$ & $\begin{array}{l}C \\
C, D\end{array}$ & $\begin{array}{l}\text { Yes } \\
\text { Yes }\end{array}$ & $\begin{array}{l}\text { Yes } \\
\text { Yes }\end{array}$ & $\begin{array}{l}\mathrm{T} \\
\mathrm{T}\end{array}$ \\
\hline Incineration & D & Yes & Yes & 0 \\
\hline $\begin{array}{l}\text { Electropolishing } \\
\text { and Vibratory } \\
\text { Finishing }\end{array}$ & D & Yes & Yes & $T$ \\
\hline $\begin{array}{l}\text { Remote-Controlled } \\
\text { Equipment }\end{array}$ & $D$ & Yes & Yes & $T$ \\
\hline
\end{tabular}

(a)C indicates implementation during the design phase, before construction; $D$ indicates delayed implementation.

(b)From Reference 1, Table 2.5-1; $T=$ thousands, $0=$ zero.

should be implemented in the plant design phase before construction begins, but some may be delayed until after plant startup, but prior to decommissioning. Table 13.2-1 also shows whether or not a radiation dose saving is expected during operation as well as during plant decommissioning. In addition, it shows a general range of cost per man-rem saved, not including any savings from the avoidance of purchasing replacement power during the plant operating life.

\subsubsection{Improved Documentation}

Improved documentation includes complete and accurate as-built drawings, construction photographs, and maintenance records and photographs; scale models and mock-ups; and plainly and properly labeled equipment and piping. These records should emphasize component and equipment locations., materials of construction, concrete pours, concrete penetrations, and the location of reinforcing steel embedded in concrete. Maintenance records can be useful to indicate such things as improved methods of equipment removal, shielding, and decontamination. Benefits accrue, during both operation and decommissioning because of 
better planning possibilities; better informed (and, therefore, more efficient) personnel; and opportunities for dry runs on mock-ups, resulting in improved performance of particular tasks. Improved documentation is important for deferred dismantlement, since it is unlikely that the operating staff will be available for consultation.

\subsubsection{Improved Access to Contaminated Equipment}

Access to contaminated equipment is improved by the installation of removable roof panels, removable wall panels, or wider labyrinth openings (this alternative has already been implemented to a large extent in the reference BWR). Improved access simplifies removal of contaminated equipment for maintenance or replacement during plant operation, as well as for disposal during decommissioning. Candidate equipment for such treatment include contaminated tanks, demineralizers, filters, heat exchangers, and pumps. Occupational radiation dose would be reduced during maintenance and during decommissioning because these components could be removed or serviced more rapidly or could be remotely handled more easily than would otherwise be the case.

\subsubsection{Different Materials in the Reactor Vessel Internals}

Removal of ${ }^{59}$ Co from or substitution of zircaloy for the stainless steel used in the reactor vessel internals eliminates the production of ${ }^{60} \mathrm{Co}$ as a neutron-activation product and greatly reduces the radioactivity of the reactor vessel internals following operation. Measurements made during the dismantlement of the Elk River Reactor showed a ten-fold difference in radiation dose rate between an upper core shroud assembly of stainless steel and a lower core shroud assembly of zircaloy, both of which were in similar neutron flux environments. ${ }^{(6)}$ In addition to reducing radioactivity in the reactor vessel internals, this technique reduces ${ }^{60} \mathrm{Co}$ as a corrosion product in plant contamination.

The benefit to operation as well as to decommissioning is substantially reduced radiation dose rates to the workers. In implementing this technique, care must be taken for neutron physics considerations in the design of the vessel internals to ensure that the reactor performance is not adversely affected and that the neutrons do not cause increased activation in a less desirable area elsewhere. 


\subsubsection{Protection of Concrete from Contamination}

A cost-effective method of protecting concrete surfaces from spills, seepage, and leaks of radioactive liquids is the application of an epoxy coating. During dismantlement, contaminated concrete surfaces must be spalled and removed to reduce the contamination to acceptable levels. If the concrete surfaces are protected with an epoxy coating and the coating is kept intact during the 1 ife of the plant, radioactive contamination may be easily removed during operation, thus decreasing the associated radiation dose. The advantages in decommissioning are: less occupational radiation dose is received during concrete decontamination; most costs of concrete removal, handling, and disposal are avoided; and less disposal space is required.

\subsubsection{Improved Shielding}

The use of improved shielding reduces radiation dose to maintenance or decommissioning personnel and, at the same time, permits quasi hands-on work. Two possible alternatives are: 1) pipe shielding, and 2) a self-contained shielded vehicle with manipulator arms.

Presently, piping in power reactors is only insulated to maintain thermal efficiency. Lead shielding with an insulation gap would provide both radiation and thermal shielding. However, this would require stronger pipe supports. Pipe shielding would reduce background radiation near valves and pumps, which require much maintenance in an operating plant, and thus benefit operation as well as decommissioning.

Portable shields are used to provide temporary working areas in high radiation fields. However, a single-place shield does not provide sufficient protection against reflected radiation. A shielded vehicle equipped with manipulator arms, capable of performing functions similar to remote manipulators in hot cells, could be used. Such a vehicle would provide the required protection during both maintenance and decommissioning activities. The vehicle should be fitted with track and should contain its own life-support systems. Fail-safe power supplies are required to ensure that the onerator can always safely leave high radiation areas. Such a vehicle would permit maintenance or decommissioning tasks to be carried out in higher radiation fields, for longer periods of time, 
and by fewer workers than are otherwise possible. On the other hand, for maneuverability, this vehicle may require larger work areas and greater distances between components.

\subsubsection{Incineration of Combustible Dry Solid Wastes}

If compaction is possible, dry solid wastes can be reduced in volume by a factor of approximately 5. Incineration can reduce the volume of combustible materials by an additional factor of 5 . A solids-burning facility includes a feed preparer, an incinerator fired by available fuel (i.e., oil or gas), an afterburner, a heat exchanger/economizer, a filter chain (i.e., bag and HEPA), a stack with off-gas monitoring capability, and ash collection and packaging facilities. Extensive off-gas treatment is not usually necessary because of the low specific activity of and the absence of highly toxic constituents in the contaminated waste.

The advantages of an incinerator are: 1) a reduction in the volume of material that must be packaged and disposed of during both operation and decommissioning, and 2) a slight reduction in occupational and public radiation dose due to efficiencies in handling and transporting the wastes.

\subsubsection{Electropolishing and Vibratory Finishing}

Electropolishing is an excellent method of preparing smooth metallic surfaces to which radioactive deposits do not adhere we11, and also of removing contamination from metal surfaces. (7) Electropolishing removes surface layers of the metal, thereby both polishing the metal and removing undesirable overlying coatings. In-situ application of electropolishing can be made in many situations, both during a reactor outage and during decommissioning. Electropolishing is described in greater detail in Appendix $G$ in Volume 2. Vibratory finishing has proven to be an excellent way for removing surface contamination from non-metallic objects and for preparing metallic objects for electropolishing. (7)

\subsubsection{Remote-Controlled Equipment}

The performance of radiation surveys, simple routine maintenance, and visual examination in areas of medium to high radiation dose rate causes inefficient use of personnel because of limited residence time in these areas. 
The use of remote-controlled equipment to perform these functions would reduce personnel dose and provide more efficient use of personnel.

To be reliable, a remote-control unit that is capable of carrying out these tasks must require little maintenance, be reasonably compact and inexpensive, be readily decontaminable, and be mobile (both operating unit and control console). Many non-nuclear jobs require a unit that could maneuver in 1 imited space, operate in a range of temperatures and in hazardous locations (e.g., in little or no oxygen or under water), and perform boring jobs. In addition to these requirements, nuclear work requires operation in radiation fields. Reliability of such a unit is especially important, since a breakdown in service could not only delay a key operation, but could also compound the situation by requiring removal and repair of the unit, thus increasing the radiation dose to personnel.

A general-service, remote-control unit might contain a manipulator, a TV camera, a radiation monitoring device, and a hoist with an extendable mast. It could perform radiation surveys and normal inspections, place shielding, move and/or lift small objects (i.e., drums, liquid filters), operate valves, make connections, and tighten nuts. 


\section{REFERENCES}

1. E. B. Moore et al., Facilitiation of Decommissioning Light Water Reactors, NUREG/CR-0569, Prepared by Pacific Northwest Laboratory for U.S. Nuclear Regulatory Commission, December 1979.*

2. R. I. Smith, G. J. Konzek and W. E. Kennedy, Jr., Technology, Safety and Costs of Decommissioning a Reference Pressurized water Reactor Power Station, NUREG/CR-0130, Prepared by Pacific Northwest Laboratory for U.S. Nuclear Regulatory Commission, June 1978. *

3. A. H. Schilling, H. E. Lippek, P. D. Tegeler and J. D. Easterling, Decommissioning Commercial Nuclear Facilities: A Review and Analysis of Current Regulations, NUREG/CR-0671, Prepared by Pacific Northwest Laboratory and Battelle Human Affairs Research Centers for U.S. Nuclear Regulatory Commission, August 1979.*

4. Ninth Annual Occupational Radiation Exposure Report, 1976, NUREG-0322, U.S. Nuclear Regulatory Commission, p. 10, Table 4, October 1977. **

5. R. 0. Poh1, "Radiation Exposure in LWR's Higher Than Predicted," Nuclear Engineering International, p. 32, January 1977.

6. Final Elk River Reactor Program Report, United Power Association, Elk River, MN 55330, November 1974.

7. R. P. Allen, H. W. Arrowsmith, L. A. Charlot, and J. L. Hooper, Electropolishing as a Decontmination Process: Progress and Applications, Battelle, Pacific Northwest Laboratories, PNL-SA-6858, Apri1 1978.

* Available for purchase from the NRC/GPO Sales Program, U.S. Nuclear Regulatory Commission, Washington, D.C. 20555, and the National Technical Information Service, Springfield, Virginia 22161.

** Available for purchase from the National Technical Information Service, Springfield, Virginia 22161. 
1 


\section{IMPACTS OF ALTERNATE STUDY BASES}

The results presented previously in this report are based on the characteristics of the reference BWR and on the conditions postulated to exist in that plant at the end of its operating 1 ife. In this chapter, the impacts on cost and/or radiation dose of different size plants, increased radiation dose rates, different contractual arrangements, increased waste disposal charges, and different plant designs are examined. Details of the analyses of these alternate study bases are presented in Appendix 0 in Volume 2.

\subsection{ESTIMATED COSTS AND RADIATION DOSES AS A FUNCTION OF PLANT SIZE}

To obtain relative cost and radiation dose estimates for decommissioning, six additional BWR stations are examined by comparing their major components with the same or similar components at the reference BWR. The plants examined, Vermont Yankee (1593 MWt), Oyster Creek (1600 MWt), Monticello (1670 MWt), Cooper (2381 MWt), Dresden 2 or 3 (2527 MWt), and Peach Bottom 2 or 3 (3293 MWt), together with the reference plant (3320 MWt), span the range of commercial BWR power stations in service. The plants are quite similar, differing principally in reactor containment design.

For each plant, individual cost estimates for decommissioning are developed for each of the major components relative to the same components from the reference BWR. These estimates are fitted with a simple algebraic expression as a function of the thermal capacity of the plant to permit interpolation to plant sizes other than those studied. A composite cost estimate is developed for each plant that is weighted over all of the major components, and these composite estimates are also fitted with a simple algebraic expression as a function of the plant power rating (PPR) in thermal megawatts to obtain an overall scaling factor (OSF). This latter expression is:

$$
O S F=0.324+\left(2.035 \times 10^{-4}\right) P P R
$$


Similar cost analyses are made for preparations for passive safe storage, entombment, and deferred dismantlement. Public and occupational radiation dose estimates associated with the various decommissioning actions are also examined for their variation with plant size. In addition, the effect of plant size on demolition costs is examined. The results of these analyses are summarized in Table 14.1-1.

TABLE 14.1-1. Scaling Relationships for Decommissioning

Costs $(a)$

Immediate Dismantlement

Preparations for Passive Safe Storage

Continuing Care for Passive Safe Storage

Deferred Dismantlement after Passive Safe Storage

$$
\begin{gathered}
\text { (up to } 30 \text { years) } \\
\text { (after } 50 \text { years) } \\
\text { (after } 100 \text { Years) } \\
\text { Entombment } w / \text { internals } \\
\text { w/o internals }
\end{gathered}
$$

Facility Demolition

Radiation Dose (d) $^{\text {Ration }}$

Radiation Workers

General Public

$$
\begin{aligned}
& \$ 43.550 M^{(b)} \times \text { OSF } \\
& \$ 21.298 M \times \text { OSF } \\
& \$ 0.075 M \times n \text { (years of storage) } \\
& \$ 35.493 M \times \text { OSF } \\
& \$ 26.348 M \times 0 S F \\
& \$ 26.348 M \times 0 S F \\
& \$ 34.964 M \times \text { OSF }+\$ 0.04 M \times n \text { (years) } \\
& \$ 40.581 M \times 0 S F+\$ 0.04 M \times n(\text { years }) \\
& \$ 10.584 M+\$ 1.131 \times 10^{-3} M \times(P P R) \\
& +\$ 9.957 \times 10^{-3} M \times(P P R)^{2 / 3}
\end{aligned}
$$

Reference Worker Dose x OSF

Reference Public Dose $x$ OSF

(a) Costs do not include spent fuel shipment; facility demolition cost is shown explicitly; costs in early 1978 dollars.

(b) $M=$ million.

(c) PPR = plant power rating in thermal megawatts.

(d) The reference dose is the dose estimated for a given decommissioning action at the reference BWR, as given in Chapter 11 .

The relationships given in Table 14.1-1 are evaluated for several of the plants considered in this chapter and the results of these evaluations 
are presented in Table 14.1-2. Each decommissioning step is presented separately. To determine the total cost and occupational radiation dose resulting from deferring dismantlement for 30 years, it is necessary to add the values from each step (i.e., preparations for passive safe storage plus safe storage for 30 years plus deferred dismantlement after 30 years). Details of these analyses are given in Section 0.1 of Appendix 0.

\section{TABLE 14.1-2. Estimated Costs/0ccupationa] Different Size BWR Plants(a)} Radiation Doses for Decommissioning

\begin{tabular}{|c|c|c|c|c|}
\hline & \multicolumn{3}{|c|}{ Station } \\
\hline & & Vermont Yankee & Cooper & WNP-2 \\
\hline Power Rating & (thermal megawatts) & 1593 & 2381 & 3320 \\
\hline Overall Scaling Factor & $(O S F[P P R]))$ & 0.648 & 0.809 & 1.000 \\
\hline Immediate Dismantlement & (\$millions) & 28.3 & 35.3 & 43.6 \\
\hline & $(\operatorname{man}-r e m)$ & 1196 & 1493 & 1845 \\
\hline Entombment: ${ }^{(b)}$ & & & & \\
\hline w/internals & (\$ millions) & 22.7 & 28.3 & 35.0 \\
\hline & $(\operatorname{man}-r e m)$ & 1019 & 1273 & 1573 \\
\hline w/o internals & (\$millions) & 26.3 & 32.8 & 40.6 \\
\hline & (man-rem) & 1091 & 1362 & 1684 \\
\hline Preparations for Passive & (\$ millions) & 13.8 & 17.2 & 21.3 \\
\hline sate storage & (man-rem) & 243 & 303 & 375 \\
\hline Safe Storage: & & & & \\
\hline for 30 years & (\$ millions) & 2.0 & 2.0 & 2.0 \\
\hline & (man-rem) & 6.5 & 6.5 & 6.5 \\
\hline for 50 years & (\$ millions) & 3.4 & 3.4 & 3.4 \\
\hline & (man-rem) & 10 & 10 & 10 \\
\hline for 100 years & (S millions) & 6.9 & 6.9 & 6.9 \\
\hline & (man-rem) & 10 & 10 & 10 \\
\hline Deferred Dismantlement: & & & & \\
\hline after 30 years & (\$ millions) & 23.0 & 27.8 & 35.5 \\
\hline & (man-rem) & 23 & 29 & 36 \\
\hline after 50 years & (\$ millions) & 17.1 & 21.4 & 26.4 \\
\hline & (man-rem) & 1.9 & 2.4 & 3 \\
\hline after 100 years & (\$millions) & 17.0 & 21.3 & 26.3 \\
\hline & $(\operatorname{man}-r e m)$ & $<1$ & $<1$ & $<1$ \\
\hline Facility Demolition & (\$ millions) & 13.7 & 15.0 & 16.6 \\
\hline
\end{tabular}

(a) Costs do not include spent fuel disposal.

(b) Entombment costs do not include continuing care costs $(\$ 0.04 \mathrm{M} / \mathrm{yr})$. 


\subsection{IMPACT OF INCREASED RADIATION DOSE RATES}

The radiation dose rate data given in Chapter 7 and Appendix $D$ were obtained from plants that had been operating for 6 years or less and may not be representative of conditions in plants after 30 to 40 years of operation. For this analysis, an increase of a factor of three in the radiation dose rates from deposited activated corrosion products in the various fluid systems is postulated as a reasonable upper-bound condition that could be tolerated for continued plant operation.

If no actions were taken to reduce radiation exposure, the accumulated occupational radiation dose for decommissioning workers during immediate dismantlement would be increased by over a factor of two, from 1845 man-rem to 4573 man-rem; during preparations for passive safe storage, from 375 manrem to 759 man-rem; and during entombment (scenario-1), from 1684 man-rem to 4154 man-rem. Additional staff would have to be hired to keep the individual worker dose within allowable limits during immediate dismantlement and entombment, at an additional cost of about $\$ 6$ million. No significant increase in cost is postulated for preparing the reference BWR for passive safe storage.

It is concluded that the best way to handle the problem of increased radiation dose rates from the activated corrosion products deposited throughout the various fluid systems is to increase the effectiveness of the chemical decontamination program. For the decontamination technique postulated in this study, it is estimated that increasing the circulation time of the solution about $50 \%$ would reduce the residual radioactivity by about a factor of three, thus achieving the same dose rate conditions assumed in the base analysis. The small incremental cost of the extended circulation time would be due to additional electric power and staff labor. This approach would also be most consistent with the principles of ALARA, since the occupational radiation dose associated with extending the circulation time of the decontamination solution is relatively small. Details of this analysis are given in Section 0.2 of Appendix 0. 


\subsection{SENSITIVITY OF DECOMMISSIONING COSTS TO CONTRACTUAL ARRANGEMENTS}

The particular contractual arrangements made can affect the total cost of decommissioning the reference BWR. A likely contractual arrangement is postulated and the costs evaluated, relative to the base case evaluated in this study. The arrangement analyzed is for the utility to employ contractors to provide the bulk of the decommissioning effort, while retaining certain overview and control functions. Under this arrangement, the cost of immediate dismantlement (not including spent fuel disposal or facility demolition) is increased by about $31 \%$, from $\$ 44$ million to $\$ 54$ million. Details of this analysis are given in Section 0.3 of Appendix 0.

\subsection{SENSITIVITY OF DECOMMISSIONING COSTS TO WASTE DISPOSAL CHARGES}

The impact of increases in disposal charges at a shallow-land burial ground and at a deep geologic repository on the total cost of decommissioning the reference BWR is examined. It is concluded that a doubling of the burial ground charges would result in an increase of less than $9 \%$ in the overall cost of immediate dismantlement. For the relatively small volume $\left(\sim 89 \mathrm{~m}^{3}\right)$ of highly activated material postulated for deep geologic disposal, a tripling of the emplacement charges (from $\$ 7,100 / \mathrm{m}^{3}$ to $\$ 21,000 / \mathrm{m}^{3}$ ) would increase the total dismantlement cost by about $6 \%$, or $\$ 2$ million. However, if all of the radioactive waste from immediate dismantlement $\left(\sim 18,876 \mathrm{~m}^{3}\right)$ is placed in a deep geologic repository, the total disposal cost could exceed $\$ 212$ million. Thus, there is a strong incentive to minimize the volume of material that is disposed of by this method. Details of this analysis are given in Section 0.4 of Appendix 0.

\subsection{SENSITIVITY OF DECOMMISSIONING COSTS TO PLANT DESIGN}

The principal design differences among BWR power plants are in the containment structure and the pressure suppression system. Three designs (Mark I, Mark II, and Mark III) are examined to determine the effect of the differences in plant design on decommissioning costs. It is concluded that there is no significant difference in the cost of dismantling a BWR containment structure, whether of a Mark I, Mark II, or Mark III design. Details of the analysis are given in Section 0.5 of Appendix 0. 
01

0 


\section{GLOSSARY}

Abbreviations, acronyms, symbols, terms, and definitions used in this study and directly related to BWR decommissioning work and associated technology are defined and explained in this chapter. The chapter is divided into two parts. The first contains abbreviations, acronyms, and symbols, and the second contains terms and definitions (including those used in a special sense for this study). Common terms covered adequately in standard dictionaries are not included.

\subsection{ABBREVIATIONS, ACRONYMS, AND SYMBOLS}

Abbreviations and Acronyms

$\begin{array}{ll}\text { AEC } & \text { Atomic Energy Commission } \\ \text { ALARA } & \text { As Low As Reasonably Achievable }{ }^{(a)} \\ \text { ANSI } & \text { American National Standards Institute } \\ \text { BWR } & \text { Boiling Water Reactor } \\ \text { CFR } & \text { Code of Federal Regulations (a) } \\ \text { Ci } & \text { Curie } \\ \text { Cpm } & \text { Counts Per Minute } \\ \text { CS } & \text { Carbon Stee Count Rate) } \\ \text { DF } & \text { Decontamination Factor (a) } \\ \text { DOE } & \text { Department of Energy } \\ \text { DOT } & \text { Department of Transportation } \\ \text { dpm } & \text { Disintegrations Per Minute } \\ \text { EC } & \text { Electron Capture }\end{array}$

(a)See Section 15.2 for additional information or explanation. 


$\begin{array}{ll}\text { EFPY } & \text { Effective Full Power Year(s) } \\ \text { EPA } & \text { Environmental Protection Agency } \\ \text { EPRI } & \text { Electric Power Research Institute } \\ \text { ERDA } & \text { Energy Research and Development Administration } \\ \text { FSAR } & \text { Final Safety Analysis Report } \\ \text { Ge(Li) } & \text { Germanium-Lithium (detectors) } \\ \text { GVW } & \text { Gross Vehicle Weight } \\ \text { HEPA } & \text { High-Efficiency Particulate Air (filters) } \\ \text { HP } & \text { Health Physicist (a) } \\ \text { HVAC } & \text { Heating, Ventilation and Air Conditioning } \\ \text { IB } & \text { Inner Bremsstrahlung (a) } \\ \text { ICRP } & \text { International Commission on Radiological Protection } \\ \text { LLD } & \text { Lower Limit of Detection } \\ \text { LWR } & \text { Light Water Reactor } \\ \text { mR } & \text { Milliroentgen, see also R (Roentgen) } \\ \text { mrad } & \text { Millirad, see also rad } \\ \text { mrem } & \text { Millirem, see also rem } \\ \text { MUF } & \text { Material Unaccounted For } \\ \text { MWD/MTU } & \text { Thermal Megawatt Day per Metric Ton of Uranium } \\ \text { MWe } & \text { Megawatts, electric } \\ \text { MWt } & \text { Megawatts, thermal } \\ \text { NaI } & \text { Nodium Iodide (detectors) } \\ \text { NRC } & \\ \text { NSSS } & \end{array}$

(a)See Section 15.2 for additional information or explanation. 


$\begin{array}{ll}\text { OSF } & \text { Overall Scaling Factor } \\ \text { PWR } & \text { Pressurized Water Reactor } \\ \text { QA } & \text { Quality Assurance } \\ \text { QC } & \text { Quality Control } \\ \text { R } & \text { Roentgen (a) } \\ \operatorname{rad}^{(a)} & \text { Radiation Absorbed Dose } \\ \operatorname{rem}^{(a)} & \text { Roentgen Equivalent Man } \\ \text { SF } & \text { Scaling Factor } \\ \text { SNM } & \text { Special Nuclear Material (a) } \\ \text { SS } & \text { Stainless Steel }\end{array}$

Symbols
$\alpha$
Alpha Radiation (a)
$\beta$
Beta Radiation (a)
$\gamma$
Gamma Radiation(a)
$x$
Chi, Concentration $\left(\mathrm{Ci} / \mathrm{m}^{3}\right)$
$Q$
Released Quantity of Radioactive Material (Ci)
$Q^{\prime}$
Release Rate of Radioactive Material ( $\mathrm{Ci} / \mathrm{sec}$ )
$\bar{x} / Q^{\prime}$
Chi-bar/Q prime, normalized average air concentration $\left(\mathrm{Ci} / \mathrm{m}^{3}\right.$ per $\mathrm{Ci} / \mathrm{sec}$ released, also written $\left.\mathrm{sec} / \mathrm{m}^{3}\right)$. Also called the annual average atmospheric dilution factor.

(a) See Section 15.2 for additional information or explanation. 


\subsection{GLOSSARY DEFINITIONS}

Abnormal Environmental Occurrence:

Absorbed Dose:

Acceptable Residual

Radioactive

Contamination Levels:

Activity:

Airborne Radioactive Material:

Airborne Release:

ALARA :

Alpha Decay:

Alpha Emitter:

Alpha Particle:

Atmospheric Release:
An event that 1) results in noncompliance with, or is in violation of, an environmental technical specification, or 2) results in uncontrolled or unplanned releases of chemical, radioactive, or other discharges in excess of federal, state, or local regulations. (See Technical Specifications.)

The amount of energy imparted by ionizing radiation to a unit mass of irradiated material at the place of interest. Also known as dose or dosage, it is defined in terms of rems or rads.

Those levels of radioactive contamination remaining at a decommissioned facility or on its site that are acceptable to the NRC for termination of the facility operating license and unrestricted release of the site.

Sometimes used for the term "radioactivity." (See Radioactivity.)

Radioactive particulates, mists, fumes, and/or gases in air.

The amount of a material of interest dispersed into the air inside a building.

An operating philosophy to maintain worker exposure to ionizing radiation As Low As is Reasonably Achievable.

Radioactive decay in which an alpha particle is emitted. This transformation lowers the atomic number of the decaying nucleus by two and its mass number by four.

A radionuclide that characteristically undergoes transformation by emission of alpha particles.

A positively charged particle emitted by certain radioactive materials. Made up of two neutrons and two protons, it is identical to the nucleus of a helium atom. It is the least penetrating of the three common types of radiation (alpha, beta, and gamma) emitted by radioactive material.

The amount of a material of interest released to the a tmosphere. 
Anticontamination Clothing:

Atomic Number ( $\mathrm{Z})$ :

Background:

Beta Decay:

Beta Emitter:

Beta Particle:

Burial Ground:

Burnup, Specific

Byproduct Material:

Capacity Factor:
Special clothing worn in a radioactively contaminated area to prevent personal contamination.

The number of protons in the nucleus of an atom; also the positive charge of the nucleus. Each chemical element has its characteristic atomic number, and the atomic numbers of the known elements (both natural and man-made) form a complete series from 1 (hydrogen) through 105 (hahnium).

Radiation originating from sources other than the source of interest (i.e., the nuclear plant). Background radiation includes natural radiation (e.g., cosmic rays and radiation from naturally radioactive elements) as well as man-made radiation (e.g., fallout from atmospheric weapons testing).

Radioactive decay in which a beta particle is emitted. This transformation changes only the atomic number of the nucleus, raising or lowering $Z$ by one for emission of a negative or positive beta particle, respectively.

A radionuclide that characteristically undergoes transformation by emission of beta particles.

An electron, of either positive or negative charge, emitted by an atomic nucleus in a nuclear transformation.

An area specifically designated for shallow subsurface disposal of solid radioactive wastes to temporarily isolate the waste from man's environment.

The total energy released per unit mass of a nuclear fuel. It is commonly expressed in megawatt-days per ton.

Any radioactive material (except source material and special nuclear material) obtained incidentally during the production or use of source or special nuclear material.

The ratio of the electricity actually produced by a nuclear power plant to the electricity that would be produced if the reactor operated continuously at design capacity. 
Cask:

Chemical Limits:

Code of Federal

Regulations (CFR):

Contact Maintenance:

Contamination:

Count Rate:

Curie:
Cask Liner:

A tightly sealing, heavily shielded, reusable shipping container for radioactive materials.

A tightly sealing, disposable metal container used inside a cask for shipping radioactive materials.

Maximum chemical concentrations or quantities imposed upon gaseous or liquid effluents discharged from a facility to the environment, and consistent with known air- and water-quality standards.

A codification of the general rules by the executive departments and agencies of the federal government. The Code is divided into 50 Titles that represent broad areas subject to federal regulation. Each Title is divided into Chapters that usually bear the name of the issuing agency. Each Chapter is further subdivided into Parts covering specific regulatory areas.

"Hands-on" maintenance, or maintenance performed by direct contact of personnel with the equipment.

Typically, most nonradioactive maintenance is contact maintenance.

Undesired (e.g., radioactive or hazardous) material that is 1) deposited on the surfaces of, or internally ingrained into, structures or equipment, or 2) mixed with another material.

Continuing Care Period: The surveillance and maintenance phase of safe storage or entombment, with the facility secured against intrusion.

The measured rate of the detection of ionizing events using a specific radiation detection device.

A unit of radioactivity, abbreviated $\mathrm{Ci}$. One curie equals $3.7 \times 10^{10}$ nuclear transformations per second. Several fractions of the curie are in common usage:

- Millicurie, abbreviated mCi. One-thousandth of a curie $\left(3.7 \times 10^{7} \mathrm{~d} / \mathrm{s}\right)$.

- Microcurie, abbreviated $\mu \mathrm{Ci}$. One-millionth of a curie $\left(3.7 \times 10^{4} \mathrm{~d} / \mathrm{s}\right)$.

- Nanocurie, abbreviated nCi. One-billionth of a curie $(37 \mathrm{~d} / \mathrm{s})$. 
Decay, Radioactive:

Decommissioning:

Decontamination:

Decontamination

Agents:

Decontamination

Factor (DF):

Deep Geologic

Disposal:

De minimus Lever:

Design Basis

Accident:

Discount Rate:

Disintegration, Nuclear:

Disintegration

Rate:
- Picocurie, abbreviated pCi (replaces the term $\mu \mu \mathrm{C} i)$. One-millionth of a microcurie $(0.037 \mathrm{~d} / \mathrm{s})$.

A spontaneous nuclear transformation in which charged particles and/or gamma radiation are emitted.

The measures taken following a nuclear facility's operating life to ensure the protection of the public from any residual radioactivity or other hazards present in the facility.

Those activities employed to reduce the levels of contamination in or on structures, equipment, and materials.

Chemical or cleansing materials used to effect decontamination.

The ratio of the initial amount (i.e., concentration or quantity) of an undesired material to the final amount resulting from a treatment process.

Placement of radioactive materials in stable geologic formations far beneath the earth's surface, to isolate them from man's environment.

That level of contamination acceptable for unrestricted public use or access.

A postulated accident believed to have the most severe expected impacts on a facility. It is used as the basis for design and safety analysis.

The rate of return on capital that could be realized in alternative investments if the money were not committed to the plan being evaluated (i.e., the opportunity cost of alternative investments), equivalent to the weighted average cost of capital.

The spontaneous (radioactive) transformation of an atom of one element to that of another, characterized by a definite half-life and the emission of particles or radiation from the nucleus of the first element.

The rate at which disintegrations (i.e., nuclear transformations) occur, in events per unit time (e.g., disintegrations per minute $[\mathrm{dpm}]$ ). 
Dismant lement:

Dispersion:

Disposal:

Dose, Absorbed:

Dose, Equivalent:

Dose, Occupational:

Dose, Radiation:

Dose Rate:

Dosimeter:

Electron Capture (EC): The capture of an orbital electron by the radioactive

Entombment: nucleus of an atom. This transformation decreases the atomic number of the nucleus by one.

Those actions required to disassemble and remove sufficient radioactive or contaminated material from a facility to permit release of the property for unrestricted use.

A process of mixing one material within a larger quantity of another, causing the first material to be diluted (i.e., reduced in concentration). For example, material released to the atmosphere is dismaterial's concentration with distance from the source.

The disposition of materials with the intent that they will not enter man's environment in sufficient amounts to cause a significant health hazard.

See Absorbed Dose.

Expresses the amount of ionizing radiation that is effective in the human body, in units of rems. Modifying factors associated with human tissue and body are taken into account. Equivalent dose is the product of absorbed dose, a quality factor, and a distribution factor. Referred to as Dose in this study.

An individual's exposure to ionizing radiation (above background) as a result of his employment, expressed in rems.

As commonly used, the quantity of radiation absorbed in a unit mass of a medium, frequently a human organ, expersed in rems.

The radiation dose delivered per unit time, expressed in units of rems per hour.

A device, such as a film badge or an ionization chamber, that measures radiation dose.

The encasement of radioactive materials in concrete or other structural material sufficiently strong and structurally long-lived to ensure retention of the radioactivity until it has decayed to levels that permit unconditional release of the site. persed in (mixed with) air, reducing the released 
Environmental

Surveillance:

Exposure:

Facility:

Fission:

Fission Products:

Food Chain:

Fuel Assembly:

Fuel Cycle:
A program to monitor the impact of discharges from industrial operations on the surrounding region. As used in this study, it is the program to monitor the extent and consequences of releases of radioactivity or chemicals from the nuclear power plant.

A measure of the ionization produced in air by $x$ or gamma radiation. It is the sum of the electrical charges on all ions of one sign produced in air when all electrons liberated by photons in a volume element of air are completely stopped in air, divided by the mass of the air in the volume element. The special unit of exposure is the roentgen. (See Roentgen.)

The physical complex of buildings and equipment on a plant site.

The splitting of a heavy atomic nucleus into two or more nearly equal parts (nuclides of lighter elements), accompanied by the release of a relatively large amount of energy and (generally) one or more neutrons. Fission can occur spontaneously, but usually it is caused by nuclear absorpton of gamma rays, neutrons, or other particles.

The lighter atomic nuclides (fission fragments) formed by the fission of heavy atoms. It also refers to the nuclides formed by the fission fragments' radioactive decay.

The pathways by which any material (such as radioactive material) passes through the environment through edible plants and/or animals to man.

A bundle of fuel rods (tubes containing nuclear fuel) housed in a fixed geometry in a metal channel. During operation, water circulated through the assembly is heated by the nuclear reaction to produce steam.

The series of steps involved in supplying fuel for nuclear power reactors and handling the spent fuel and the resultant radioactive wastes, including transportation.

Head end: Mining, milling, enrichment, and fabrication of fuel.

Back end: Includes reactors, spent fuel storage, spent fuel reprocessing, mixed-oxide fuel fabrication, and waste management. 
Gamma Rays:

Gaseous:

Greenhouse:

Half-Life, Biological :

Half-Life, Effective:

Half-Life, Radioactive:

Health Physicist:

Health Physics:

High-Leve1 Waste:

Hot Spot:
Short-wavelength electromagnetic radiation. Gamma radiation frequently accompanies alpha and beta emissions and always accompanies fission. Gamma rays are very penetrating and are best stopped or shielded against by dense materials such as lead or uranium. The rays are similar to $x$-rays, but are nuclear in origin, i.e., they originate from within the nucleus of the atom.

Material in the vapor or gaseous state, but can include entrained liquids and solids.

In nuclear terms, a temporary structure, frequently constructed of wood and plastic, used to provide a confinement barrier between a radioactive work area and a nonradioactive area.

The time required for a biological system (such as a man or animal) to eliminate, by natural processes, half the amount of a substance (such as a radioactive material) that it has absorbed.

The time required for radioactivity contained in a biological system (such as a man or animal) to be reduced by half as a combined result of radioactive decay and biological elimination.

The time in which half the atoms of a particular radioactive substance disintegrate to another form. Each radionuclide has a unique half-life. Measured half-lives vary from millionths of a second to billions of years.

A person trained to perform radiation surveys, oversee radiation monitoring, estimate the degree of radiation hazard, and advise on operating procedures for minimizing radiation exposures.

The science concerned with recognition, evaluation, and control of health hazards from ionizing radiation.

Radioactive waste from the first-cycle solvent extraction (or equivalent) during spent nuclear fuel reprocessing. Also applied to other concentrated wastes of various origins.

An area of radioactive contamination of higher than average concentration. 
Immobilization:

Inner Bremsstrahlung:

Intrusion Alarm:

Ion Exchange:

Licensed Materia7:

Liquid Radioactive Waste:

Long-Lived Nuclides:

Low-Level Waste:

Man-rem:

Mass Number $(A)$ :

Maximum-Exposed

Individual:
Treatment and/or emplacement of materials (e.g., radioactive contamination) so as to impede their movement.

Secondary electromagnetic radiation produced by deccleration of charged particles passing through matter.

A security device that detects intrusion into a protected area and initiates a visible and/or audible alarm signal.

A chemical process involving the selective adsorption (and subsequent desorption) of certain chemical ions in a solution on to a solid material, usually a plastic or resin. The process is used to separate containments from process streams, purifying them for reuse or disposal.

Source material, special nuclear material, or byproduct material received, possessed, used, or transferred under a license issued by the NRC.

Solutions, suspensions, and mobile sludges contaminated with radioactive materials.

For this study, radioactive isotopes with long halflives, typically taken to be greater than about 10 years. Most nuclides of interest to waste management have half-lives on the order of one year to millions of years.

Wastes containing low but not hazardous quantities of radionuclides and requiring little or no biological shielding; low-level wastes generally contain no more than 10 nanocuries of transuranic material per gram of waste.

Used as a unit measure of population radiation dose, calculated by summing the dose equivalent in rem received by each person in the population. Also, it is used as the absorbed dose of one rem by one person, with no rate of exposure implied.

The number of nucleons (protons and neutrons) in the nucleus of a given atom.

The hypothetical member of the public who receives the maximum radiation dose to an organ of reference. For the common case where exposure from airborne radioairborne radionuclide concentration and eats food grown at that location. 
Megawatt Day per Metric Ton:

Monitoring:

Normal Operating Conditions:

Nuclear Reaction:

Nuclear Steam Supply System:

Nuclide:

Offsite:

Onsite:

Operable:

Overpack:

Package:
A unit for expressing the thermal output obtained per unit mass of nuclear fuel.

Making measurements or observations so as to recognize the status or adequacy of, or significant changes in, conditions or performance of a facility or area.

Operation (including startup, shutdown, and maintenance) of systems within the normal range of applicable parameters.

A reaction involving a change in an atomic nucleus, such as fission, fusion, particle capture, or radioactive decay.

A contractual term designating those components of the nuclear power plant furnished by the nuclear steam supply system supplier. Generally includes those systems most closely associated with the reactor vesse1, designed to contain or be in contact with the water coming from or going to the reactor core. The nuclear steam supply system in a BWR includes:

- reactor vessel

- reactor vessel internals

- reactor core

- neutron monitoring system

- reactor water recirculation system

- control rod drive system

- residual heat removal system

- emergency core cooling systems.

See Radionuclide.

Beyond the boundary line marking the limits of plant property.

Within the boundary line marking the limits of plant property.

Capable of performing the required function.

Secondary (or additional) external containment or cushioning for packaged nuclear waste that exceeds certain limits imposed by regulation.

The packaging plus the contents of radioactive materials. 
Packaging:

Possession-only

License:

Power Reactor:

Present Value of Money:

Protective Survey:

Quality Assurance:

Quality Control:

Rad:

Radiation:

Radiation Area:
The assembly of radioactive material in one or more containers and other components as necessary to ensure compliance with applicable regulations.

An amended operating license issued by NRC to a nuclear facility owner entitling the licensee to own but not operate the facility.

A nuclear reactor used to provide steam for electrical power generation.

The present value of a future stream of costs is the present investment necessary to secure or yield the future stream of payments, with compound interest at a given discount or interest rate. Inflation can be taken into account in this calculation.

See Radiation Survey.

The systematic actions necessary to provide adequate confidence that 1) a material, component, system, process, or facility performs satisfactorily or as planned in service, or 2) that work is performed according to plan.

The quality assurance actions that control the attributes of the material, process, component, system, facility, or work in accordance with predetermined quality requirements.

The unit of absorbed dose. The energy imparted by ionizing radiation to a unit mass of irradiated material at the place of interest. One rad equals 0.01 joules/kilogram.

1) The emission and propagation of radiant energy: for instance, the emission and propagation of electromagnetic waves or protons. 2) The energy propagated through space or through a material medium: for example, energy in the form of alpha, beta, and gamma emissions from radioactive nuclei.

Any area, accessible to personnel, in which there exists radiation at such levels that a major portion of the body could receive a dose in excess of 5 millirem in any one hour, or a dose in excess of 100 millirem in any 5 consecutive days. (See 10 CFR 20.202.) 
Radiation Leakage

(Direct):

Radiation, Scattered:

Radiation, Stray:

Radiation Survey:

Radioactive Material: Any material or combination of materials that spontaneously emits ionizing radiation and has a specific activity in excess of 0.002 microcuries per gram of material. (See 49 CFR 173.389(e).)

Radioactive Series:

Radioactivity:

Radioactivity, Artificial:

Radioactivity, Induced:

Radioactivity, Natural:

Al1 radiation coming from a source housing except the useful beam.

Radiation that has deviated in direction during its passage through a substance. It may also be modified by a decrease in energy.

The sum of leakage and scattered radiation; also called "shine."

An evaluation of radiation and associated hazards incidental to the production, use, or existence of radioactive materials. It normally includes a physical survey of the arrangement and use of equipment and measurements of the radiation dose rates under expected conditions of use. Also called protective survey.

A succession of nuclides, each of which transforms by radioactive disintegration into the next until a stable nonradioactive nuclide results. The first member is called the "parent," the intermediate members are called "daughters," and the final stable member is called the "end product."

The property of certain nuclides of spontaneously transforming to other nuclides by emitting particles and/or gamma radiation. Also used to describe the number of nuclear transformations occurring in a given quantity of material per unit time. Often shortened to "activity."

Man-made radioactivity produced by particle bombardment or electromagnetic irradiation, as opposed to natural radioactivity.

Radioactivity produced in a substance after bombardment with neutrons or other particles. The resulting radioactivity is "natural radioactivity" if formed by nuclear reactions occurring in nature and "artificial radioactivity" if the reactions are caused by man.

Radioactivity exhibited by more than fifty naturally occurring radionuclides. 
Radiological

Protection:

Radionuclide:

Regulatory

Guides:

Rem:

Remote Maintenance:

Reporting Levels:

Repository (Federal):

Restricted Area:
Protection against the effects of internal and external human exposure to ionizing radiation and radioactive materials.

An atom that decays radioactively. Each radionuclide decays with a characteristic half-life.

Documents that describe and make publicly available methods acceptable to the NRC staff for implementing specific parts of the NRC's regulations, to delineate techniques used by the staff in evaluating specific problems or postulated accidents, or to provide other guidance to applicants for nuclear operations. Guides are not substitutes for regulations, and compliance with them is not explicitly required. Methods and solutions different from those set out in the guides may be acceptable if they provide a basis for the findings requisite to the issuance or continuance of a permit or license by the NRC. (Government agencies other than the NRC have regulatory guides pertaining to non-nuclear matters.).

A unit of radiation dose equivalent. The dose equivalent in rems is numerically equal to the absorbed dose in rads multiplied by the quality factor, the distribution factor, and any other necessary modifying factors.

Maintenance by remote means, i.e., the human is separated by a shielding wall from the item being maintained. Used in the nuclear industry to reduce the occupational radiation doses to maintenance personnel.

Those levels or parameters called out in the environmental technical specifications, the dismantling order, and/or the possession-only license that do not limit decommissioning activities, but that may indicate a measurable impact on the environment.

A site owned and operated by the federal government for long-term storage or disposal of radioactive materials.

Any area to which access is controlled for protection of individuals from exposure to ionizing radiation and radioactive materials. 
Roentgen ( $R$ ):

Safe Storage:

Shield:

Short-Lived

Radionuclides:

Shutdown:

Site:

Solid Radioactive Waste:

Solidification:

Source Material:

Special Nuclear Material (SNM):
The unit of exposure to ionizing radiation. It is that amount of gamma or $x$-rays required to produce ions carrying one electrostatic unit of electrical charge (either positive or negative) in one cubic centimeter of dry air under standard conditions. One roentgen equals $2.58 \times 10^{-4}$ coulomb per kilogram of air. (See also Exposure.)

Those actions required to place and maintain a nuclear facility in such a condition that risk to the public is within acceptable bounds, so the facility can be safely stored for the time desired.

A body of material used to reduce the passage of ionizing radiation. A shield may be designated according to what it is intended to absorb (as a gamma-ray shield or neutron shield), or according to the kind of protection it is intended to give (as a background, biological, or thermal shield). A shield may be required to protect personnel or to reduce radiation enough to allow use of counting instruments.

For this study, those radioactive isotopes with halflives less than about 10 years.

The time during which a facility is not in productive operation.

The geographic area upon which the facility is located, subject to controlled public access by the facility licensee (includes the restricted area as designated in the NRC license).

Radioactive waste material that is essentially solid and dry, but may contain sorbed radioactive fluids in sufficiently small amounts as to be immobile.

Conversion of radioactive wastes (gases or liquids) to dry, stable solids.

Thorium, natural or depleted uranium, or any combination thereof. Source material does not include special nuclear material. (See 10 CFR 40.4(h).)

Plutonium, 233U, uranium containing more than the natural abundance of $235 \mathrm{U}$, or any material artificially enriched with the foregoing substances. SNM does not include source material. (See 10 CFR 40.4(i).) 
Surface Contamination: The deposition and attachment of radioactive materials to a surface. Also, the resulting deposits.

Surveillance:

Technical

Specifications:

Those activities necessary to ensure that the site remains in a safe condition (includes periodic inspection and monitoring of the site, maintenance of barriers preventing access to radioactive materials remaining on the site, and prevention of activities that might impair these barriers).

Requirements and limits encompassing environmental and nuclear safety that are simplified to facilitate use by plant operation and maintenance personnel. They are prepared in accordance with the requirements of 10 CFR 50.36 , and are incorporated into the operating and/or possession-only license issued by the NRC.

Track Drill:

A self-propelled, air-operated drill rig with an extendable boom capable of drilling 20 -m-deep vertical holes in concrete.

Waste Management: The planning and execution of essential functions relating to radioactive wastes, including treatment, packaging, interim storage, transportation, and disposal.

Waste, Radioactive: Equipment and materials (from nuclear operations) that are radioactive and have no further use. Also called radwaste.

X-Ray:

A penetrating form of electromagnetic radiation emitted either when the inner orbital electrons of an excited atom return to their normal state (characteristic x-rays) or when a metal target is bombarded with high-speed electrons. X-rays are always nonnuclear in origin (i.e., they originate external to the nucleus of the atom). 


\section{GENERAL REFERENCES}

American National Standard Glossary of Terms in Nuclear Science and Technology, American Nuclear Society, Hinsdale, IL, 1976.

McGraw-Hill Dictionary of Scientific and Technical Terms, McGraw-Hill, Inc., New York, NY, 1976.

Radiological Health Handbook, Public Health Service Publication No. 2106, Revised Edition, U.S. Government Printing Office, Washington, DC, January 1970.

Glossary of Nuclear Industry Terms, Standards and Specifications, Atomic Power Equipment Department, General Electric Company, San Jose, CA, September 1969. 
NRC FORM 335

(7.77)
U.S. NUCLEAR REGULATORY COMMISSION

BIBLIOGRAPHIC DATA SHEET

4. TITLE AND SUBTITLE (Add Volume No., if appropriate)

Technology, Safety and Costs of Decommissioning a Reference Boiling Water Reactor Power Station

7. AUTHOR(S)

H.D. Oak, G.M. Holter, W.E. Kennedy, Jr., G.J. Konzek 9. PERFORMING ORGANIZATION NAME AND MAILING ADDRESS (Include Zip Code)

Battelle-Pacific Northwest Laboratory

Richland, WA 99352

12. SPONSORING ORGANIZATION NAME AND MAILING ADDRESS (Include $Z_{i p}$ Code)

Division of Engineering Standards

office of Standards Development

U.S. Nuclear Regulatory Commission, Washington, D.C.20555

1 REPORT NUMBER (Assigned bV DOC) NUREG/CR-0672, Vol. 1

2. (Leave b/ank/

3. RECIPIENT'S ACCESSION NO.

5. DATE REPORT COMPLETED MONTH October

DATE REPORT ISSUED

\begin{tabular}{l|l}
\hline MONTH & YEAR \\
\hline
\end{tabular} June 1980

6. (Leave blank

8. (Leave blank)

10. PROJECT/TASK/WORK UNIT NO

11. CONTRACT NO.

FIN No. B2117

13. TYPE OF REPORT

Technical PERIOD COVERED (Inclusive dates)

Sept. 1977 - October 1979

15. SUPPLEMENTARY NOTES

14. (Leave blank)

16. ABSTRACT (200 words or less)

Technology, safety and cost information is given for the conceptual decommissioning of a large (1100MWe) boiling water reactor (BWR) power station. Three approaches to decommissioning, immediate dismantlement, safe storage with deferred dismantlement and entombment, were studied to obtain comparisons between costs, occupational radiation doses, potential dose to the public and other safety impacts. It also shows the sensitivity of decommissioning safety and costs to the power rating of a BWR in the range of 200 to 1100 MWe.

19. SE CURITY CLASS (This repor) Unclassified

20. SECURITY CLASS (This page)
21. NO. OF PAGES

22. PRICE $\$$ 